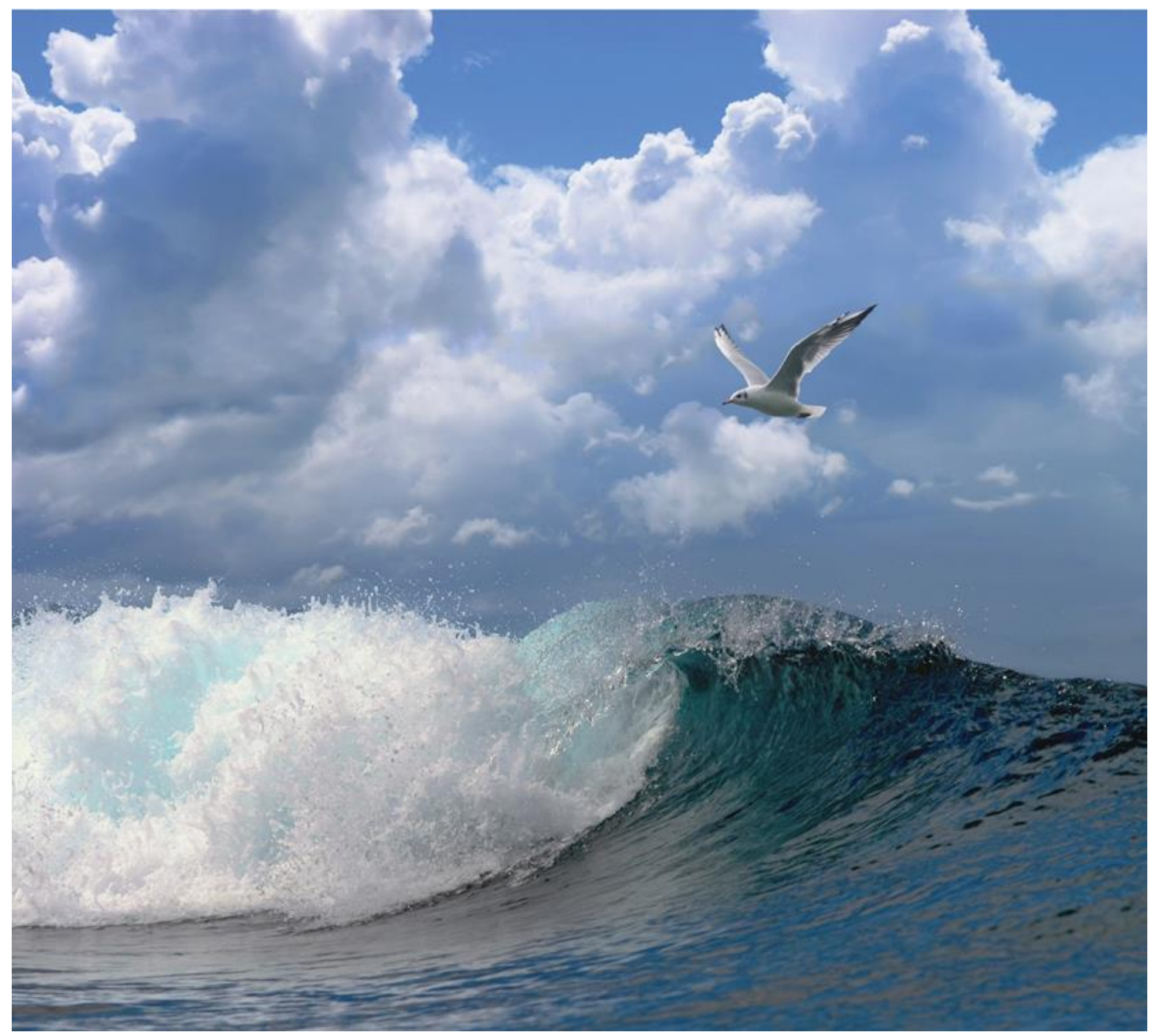

\title{
De bodemberoerende visserij in de Voordelta sinds 2004
}

Auteurs: Nicola Tien, Niels Hintzen, Ruben Verkempynck, Marloes Kraan, Brita Trapman, Johan Craeymeersch, Margriet van Asch
Wageningen University \&

Research Rapport C105/17 


\section{De bodemberoerende visserij in de Voordelta sinds 2004}

Auteur(s): $\quad$ Nicola Tien, Niels Hintzen, Ruben Verkempynck, Marloes Kraan, Brita Trapman, Johan Craeymeersch, Margriet van Asch

Publicatiedatum: 20 december 2017

Wageningen Marine Research

IJmuiden, december 2017

Wageningen Marine Research

rapport C105/17 
Nicola Tien, Niels Hintzen, Ruben Verkempynck, Marloes Kraan, Brita Trapman, Johan Craeymeersch, Margriet van Asch, 2017. Wageningen Marine Research, Wageningen UR (University \& Research centre), rapportnummer C105/17, 105 blz.

Opdrachtgever: Rijkswaterstaat WVL

T.a.v. Mennobart van Eerden

Postbus 17

8200 AA Lelystad

Dit rapport is gratis te downloaden van https://doi.org/10.18174/429215

Wageningen Marine Research verstrekt geen gedrukte exemplaren van rapporten.

(C) 2017 Wageningen Marine Research Wageningen UR

$\begin{array}{ll}\begin{array}{l}\text { Wageningen Marine Research, onderdeel } \\ \text { van Stichting Wageningen Research }\end{array} & \begin{array}{l}\text { De Directie van Wageningen Marine Research is niet aansprakelijk voor } \\ \text { gevolgschade, noch voor schade welke voortvloeit uit toepassingen van de } \\ \text { KvK nr. 09098104, }\end{array} \\ \text { WMR BTW nr. NL 8113.83.696.B16. } & \text { Marine Research opdrachtgever vrijwaart Wageningen Marine Research van } \\ \text { Code BIC/SWIFT address: RABONL2U } & \text { aanspraken van derden in verband met deze toepassing. } \\ \text { IBAN code: NL 73 RABO 0373599285 } & \begin{array}{l}\text { Dit rapport is vervaardigd op verzoek van de opdrachtgever hierboven aangegeven } \\ \text { en is zijn eigendom. Niets uit dit rapport mag weergegeven en/of gepubliceerd }\end{array} \\ & \text { worden, gefotokopieerd of op enige andere manier gebruikt worden zonder } \\ & \text { schriftelijke toestemming van de opdrachtgever. }\end{array}$




\section{Inhoud}

\section{Samenvatting}

$1 \quad$ Inleiding

$\begin{array}{llr}1.1 & \text { PMR en de platviskotters } & 7\end{array}$

$\begin{array}{lll}1.2 & \text { Onderzoeksvragen } & 7\end{array}$

$\begin{array}{lll}1.3 & \text { Methodiek } & 8\end{array}$

1.3.1 Analyse van logboek- en VMS-gegevens $\quad 8$

$\begin{array}{ll}\text { 1.3.2 Analyse van discards } & 9\end{array}$

$\begin{array}{ll}1.3 .3 & \text { Sociologische studie } \\ \end{array}$

$\begin{array}{llr}1.4 & \text { De Voordelta } & 12\end{array}$

$\begin{array}{lll}1.5 & \text { Opbouw rapport } & 13\end{array}$

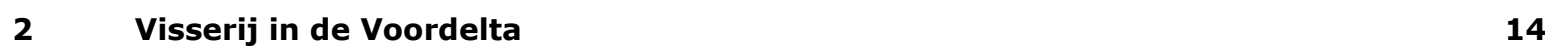

2.1 De Nederlandse vloot in de Voordelta $\quad 14$

$\begin{array}{lll}2.1 .1 & \text { Typen visserij } & 14\end{array}$

$\begin{array}{lll}2.1 .2 & \text { Inspanning per type visserij } & 15\end{array}$

$\begin{array}{lll}2.1 .1 & \text { Ruimtelijke verspreiding van de visserijen } & 17\end{array}$

2.1.2 Aantal schepen per type visserij 18

2.1.3 Aanlandingen uit de Voordelta $\quad 19$

$\begin{array}{lll}2.1 .4 & \text { Tuigen per schip } & 20\end{array}$

$\begin{array}{lll}2.2 & \text { De buitenlandse visserij } & 21\end{array}$

$\begin{array}{llr}2.3 & \text { Recreatieve visserij } & 22\end{array}$

$3 \quad$ Trends in inspanning $\quad 23$

3.1 Platviskotters in de Voordelta $\quad 23$

$\begin{array}{lll}3.1 .1 & \text { Jaarlijkse inspanning } & 23\end{array}$

$\begin{array}{lll}3.1 .2 & \text { Ruimtelijke trends } & 24\end{array}$

$\begin{array}{lll}3.1 .3 & \text { Seizoenstrends } & 24\end{array}$

$\begin{array}{lll}3.1 .4 & \text { Havens } & 25\end{array}$

$\begin{array}{lll}3.1 .5 & \text { Vernieuwende tuigen } & 27\end{array}$

$\begin{array}{lll}3.1 .6 & \text { Noordzeebrede visserij } & 27\end{array}$

3.1.7 Noordzeekustvisserij 30

$\begin{array}{lll}3.2 & \text { Garnalenkotters in de Voordelta } & 31\end{array}$

$\begin{array}{lll}3.2 .1 & \text { Jaarlijkse inspanning } & 31\end{array}$

$\begin{array}{lll}3.2 .2 & \text { Noordzeebrede visserij } & 32\end{array}$

$\begin{array}{lll}3.2 .3 & \text { Ruimtelijke verspreiding } & 35\end{array}$

3.3 Combinatie garnaal- en platvisvisserij

$4 \quad$ Trends in aanlandingen $\quad 38$

$\begin{array}{lll}4.1 & \text { Platviskotters in de Voordelta } & 38\end{array}$

$\begin{array}{lll}4.1 .1 & \text { Absolute aanlandingen } & 38\end{array}$

$\begin{array}{lll}4.1 .2 & \text { Commercieel vangstsucces } & 39\end{array}$

$\begin{array}{ll}4.1 .3 & \text { Aanlandingen Noordzeebreed }\end{array}$

4.1.4 Lange termijn trends $\quad 43$

4.2 Garnalenkotters in de Voordelta $\quad 44$

4.2.1 Absolute aanlandingen $\quad 44$

4.2.2 Commercieel vangstsucces $\quad 45$ 
$\begin{array}{lll}5.1 & \text { Platvisvisserij } & 46\end{array}$

5.1.1 Vis 46

$\begin{array}{lll}5.1 .2 & \text { Benthos } & 48\end{array}$

5.2 Garnalenvisserij $\quad 50$

5.2.1 Reguliere monitoringsprogramma $\quad 50$

5.2.2 Garnalenexperimenten $\quad 52$

$6 \quad$ Impact van visserij-onttrekking op de commerciële bestanden $\quad 55$

$\begin{array}{lll}6.1 & \text { Schol } & 55\end{array}$

$\begin{array}{llr}6.2 & \text { Tong } & 57\end{array}$

$\begin{array}{llr}6.3 \text { Bot } & 59\end{array}$

$\begin{array}{lll}6.4 & \text { Schar } & 61\end{array}$

$\begin{array}{lll}6.5 & \text { Garnaal } & 63\end{array}$

$\begin{array}{lll}6.6 & \text { Overige soorten } & 66\end{array}$

$7 \quad$ Totale visserij-onttrekking voor en na instelling van het BBG. 67

7.1 Totale onttrekking vis en benthos voor en na instelling van het BBG 67

7.2 Effecten onttrekking vis en garnaal op commerciële bestanden voor en na de instelling $\begin{array}{ll}\text { van het BBG } & 68\end{array}$

$8 \quad$ Gesprekken met vissers $\quad \mathbf{7 0}$

$\begin{array}{lll}8.1 & \text { Visserij in de Voordelta } & 70\end{array}$

$\begin{array}{lll}8.2 & \text { Impact van het BBG op de visserij } & 72\end{array}$

$\begin{array}{ll}8.3 & \text { Nut van de maatregelen }\end{array}$

$9 \quad$ Oorzaken van de veranderde platvisvisserij $\quad 77$

$\begin{array}{lll}9.1 & \text { Vragen } & 77\end{array}$

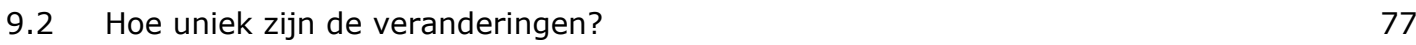

$\begin{array}{lll}\text { 9.2.1 Voordelta versus Noordzee } & 77\end{array}$

$\begin{array}{lll}9.2 .2 & \text { Voordelta versus Noordzeekust } & 77\end{array}$

9.2.3 Tijdsperiode $\quad 78$

9.3 Wat is de oorzaak voor de verandering in specifiek de Voordelta? $\quad 79$

$\begin{array}{lll}9.3 .1 & \text { Ontwikkelingen in de platvisbestanden } & 79\end{array}$

9.3.2 Ontwikkelingen in de vloot en het beleid 79

10 Conclusies $\quad 82$

\section{$\begin{array}{lr}\text { Literatuur } & \mathbf{8 3}\end{array}$}

A1.1 Experiment garnalenvisserij Voordelta 2010-2012 84

A1.2 Interviews met Voordelta vissers $\quad 86$

Doel 86

Selectie vissers $\quad 86$

$\begin{array}{ll}\text { Semi gestructureerde interviews } & 87\end{array}$

$\begin{array}{ll}\text { Resultaten } & 88\end{array}$

$\begin{array}{lr}\text { Hoofdstuk } 2 & 90\end{array}$

$\begin{array}{lr}\text { Hoofdstuk } 3 & 91\end{array}$

$\begin{array}{lr}\text { Hoofdstuk } 4 & 94\end{array}$

$\begin{array}{lr}\text { Hoofdstuk } 5 & 96\end{array}$ 
Appendix 3. Impact onttrekking overige soorten

Wijting 99

Tongschar

99

Tarbot 99

Appendix 4 Berekening visgrond en inspanning per hectare visgrond

103

Verantwoording

105 


\section{Samenvatting}

Als compensatiemaatregel voor de negatieve effecten van de aanleg van de Tweede Maasvlakte ('Maasvlakte2') werd in 2008 een Bodembeschermingsgebied ('BBG') in de Voordelta ingesteld, waarin visserij door platviskotters met motorvermogens tussen 260 en 300 PK verboden werd. Echter, voordat het BBG in werking trad, was deze visserij in het gebied van het latere BBG al vrijwel verdwenen. De enige andere bodemberoerende visserij van betekenis in dit gebied, door garnalenkotters, is juist toegenomen sinds de instelling van het BBG. Dit rapport behandelt de ontwikkelingen in de visserij door de platviskotters en de garnalenkotters van 2004 tot en met 2015, in de hele Voordelta, en specifiek met betrekking tot het BBG, met hierbij twee hoofdlijnen qua onderzoek:

1. Hoe groot was de onttrekking van vis en andere (bij)vangsten in de periode T0 (2004-2008), T1 (2009-2013) en T2 (2014-2018). Waar mogelijk is ook onderzocht, wat het effect van deze onttrekking is geweest op de omvang van de commerciële bestanden.

Met behulp van informatie uit logboeken, VMS en discard-monitoringsprogramma's zijn schattingen gemaakt van de onttrekkingen (aanlandingen en discards) van vis en benthos. Voor de onttrekking van benthos -anders dan garnaal- zijn de schattingen onzeker. De onttrekking van biomassa door de platviskotters was in 2004 al relatief klein, en is sterk afgenomen tussen 2004 en 2015 (de onderzochte datareeks loopt tot en met 2015). Tussen de T0 en de T1 is de jaarlijkse onttrekking meer dan gehalveerd van 851 naar 322 ton biomassa en tussen T1 en T2 nog verder afgenomen naar 244. De onttrekking door de garnalenvisserij is veel groter dan van de platvisvisserij. Ook is deze onttrekking juist toegenomen over de periode 2006-2015 heen (voor 2004-2005 zijn geen gegevens beschikbaar). Tussen de T0 en T1 is de onttrekking iets afgenomen van 1928 naar 1694 ton biomassa, maar in T2 sterk toegenomen naar 2682 ton. Opgeteld over beide typen visserij is de gemiddelde onttrekking van biomassa van T0 (2006-2008) naar T1 (2009-2012) afgenomen van 2779 ton naar 2016 ton maar in T2 (2014-2015) juist toegenomen naar 2926 ton.

De impact van de visserij op het schol- en tongbestand is consistent afgenomen over de drie periodes heen. Voor wijting is geen duidelijke trend over de drie periodes te zien. Er wordt voor de visbestanden hierbij aangenomen dat de biomassaontwikkelingen in de Voordelta gelijk is aan die van het hele bestand (i.e., op Noordzeeschaal en hoger). De impact op de garnaal die leeft in de Voordelta is afgenomen van T0 naar T1 maar toegenomen in T2. Voor de overige commerciële bestanden bestaan geen kwantitatieve bestandsschattingen om de impact mee te evalueren. Deze informatie kan in verdere analyses helpen de vraag te beantwoorden, wat het effect van verschillende vormen van bodemberoerende visserij op het ecosysteem is geweest.

\section{Wat zijn de oorzaken van de verminderde platvisvisserij in de Voordelta?}

Met behulp van informatie uit logboeken, VMS en interviews met vissers zijn de trends in de platvisvisserij in detail geëvalueerd en afgezet tegen de trends Noordzee breed. Boomkorvisserij in de Voordelta is een complex gebeuren, waarbij schepen meestal gedurende het jaar met meerdere tuigen op verschillende doelsoorten vissen. Een groot deel van de kotters die op platvis vist in de Voordelta vist ook - en vooral - op garnaal in de Voordelta. Bovendien zijn geen van de kotters gespecialiseerd in de Voordelta maar is dit slechts een klein deel van hun visgebied.

De grootste afname in de platvisvisserij lijkt Noordzee breed plaats te vinden: De platviskotters gaan in hun hele visgebied minder vissen over de jaren 2004-2015 heen. Binnen de Voordelta lijkt er wel een extra grote afname te zijn. Echter, het begin van deze Voordelta-specifieke afname lijkt eerder ingezet dan in de periode 2004-2015 en heeft daardoor waarschijnlijk niet te maken met het instellen van het BBG in 2008. Wel lijkt rond 2008/2009 de visserij-inspanning in de Voordelta te stabiliseren op een laag en basaal niveau. Het is mogelijk dat de komst van het BBG en de Tweede Maasvlakte hier een rol bij hebben gespeeld door grotere fragmentatie en verlies aan visserijgrond. Het instellen van het BBG kan dus een kleine, aanvullende rol hebben gespeeld in de afname van de bodemberoerende visserij in het gebied. 


\section{$1 \quad$ Inleiding}

\subsection{PMR en de platviskotters}

Als compensatiemaatregel voor de negatieve effecten van de aanleg van de Tweede Maasvlakte is in juni 2008 een Bodembeschermingsgebied (BBG) in de Voordelta ingesteld. In dit gebied van 24.550 hectare is de bodemberoerende visserij beperkt, door een verbod op boomkorvisserij met wekkerkettingen met motorvermogens tussen 260 en $300 \mathrm{PK}^{1}$. Schepen met motorvermogen boven de 300 PK waren al verboden binnen de 12-mijlszone. De instelling van het BBG betekent de facto een verbod op visserij door de platviskotters in het BBG: wekkerkettingen bij boomkorschepen worden gebruikt voor platvisvisserij en de meerderheid van deze platvisvisserij in de Voordelta (98.7\% tussen 2004-2007) vond plaats met motorvermogens van 260-300 PK. Ook zijn er rustgebieden ingesteld voor zwarte zee-eenden, waar de schepen niet mogen vissen.

Met de BBG-maatregel wordt een verbetering van de kwaliteit van habitattype 1110 (permanent overstroomde zandbanken) en daarmee van de bodemfauna nagestreefd. In de jaren 2009-2015 is in opdracht van Rijkswaterstaat Water, Verkeer en Leefomgeving (WVL) de eerste fase van de monitoring natuurcompensatie Voordelta uitgevoerd door Deltares en een consortium met onder andere IMARES (Prins et al. 2014). In deze fase werd onder andere onderzocht of de instelling van het BBG voldeed aan de compensatie-opgave. In de jaren 2016-2020 wordt in opdracht van dezelfde opdrachtgever de tweede fase van de monitoring natuurcompensatie uitgevoerd door het consortium IMARES/WMR en Deltares en andere partijen (Tulp et al. 2015).

Eén van de uitkomsten van de eerste fase was de realisatie dat de visserij-inspanning van de platviskotters in de Voordelta al was gedaald in de periode voorafgaand aan de instelling van het BBG. De visserij in het gebied van het latere BBG was al vrijwel verdwenen voordat het BBG in werking trad. In de Voordelta is de enige andere bodemberoerende visserij van betekenis de visserij op garnalen. De visserij-inspanning door de garnalenvisserij is juist toegenomen in het BBG sinds de instelling van het BBG. Dit rapport behandelt in meer detail de ontwikkelingen in de visserij door de platviskotters en de garnalenkotters, van $2004^{2}$ tot en met 2015.

\subsection{Onderzoeksvragen}

In het monitoringsplan (Tulp et al. 2015) wordt onderscheid gemaakt tussen evaluatievragen en onderzoeksvragen. De evaluatievragen zijn opgesteld door de RWS en zijn vervolgens door het consortium Wageningen Marine Research/WMR en Deltares vertaald en geconcretiseerd in onderzoeksvragen. De formulering van de onderzoeksvragen wijkt soms af van de evaluatievragen omdat er in de onderzoeksvragen naar is gestreefd om de vragen zo te formuleren dat deze ook daadwerkelijk door het in dit monitoringsplan voorgestelde onderzoek te beantwoorden zijn.

De evaluatievraag die van belang is voor dit rapport is: "Wat is het effect van verschillende vormen van bodemberoerende visserij op het ecosysteem (in termen van geschatte bijvangst, onttrekking van vis, verstoring) geweest in de periode T0 (2004-2008), T1 (2009-2013) en T2 (2014-2018)?". Deze is vertaald in de onderzoeksvraag: "Hoe groot was de onttrekking van vis en andere (bij)vangsten in de periode T0 (2004-2008), T1 (2009-2013) en T2 (2014-2018)?". Er wordt in dit rapport voor zover mogelijk ook op de bijbehorende evaluatievraag ingegaan: de impact van de visserij op de commerciële vis- en garnaalbestanden wordt geschat.

\footnotetext{
${ }^{1}$ Binnen de 12-mijl-zone is visserij met een motorvermogen van minder dan 300 PK sowieso niet toegestaan. Het grootste deel van de Voordelta valt binnen de 12-mijl-zone (zie figuur X). Voor de rest van de Voordelta en voor de overige vismethoden geldt nog steeds de beperking van $300 \mathrm{PK}$.

${ }^{2} 2004$ is het eerste jaar waarbij zowel goede VMS- als goede logboekgegevens beschikbaar zijn voor de meeste visserijen.
} 
Daarnaast is in het monitoringsplan de vraag opgenomen, wat de reden is voor de afnemende platvisvisserij voorafgaand aan 2008. Zo zouden de vissers geanticipeerd kunnen hebben op de aanstaande sluiting van het BBG. Een andere mogelijk verklaring is dat Noordzeebreed de platvisvisserij is afgenomen (niet Voordelta-specifiek dus), of dat binnen de Voordelta de visserij is afgenomen door andere factoren. Deze vraag is niet direct gelinkt aan een van de onderzoeks- of evaluatievragen, maar gaat meer over de werking van de compensatiemaatregel. Was het verdwijnen van de boomkorvloot het resultaat van de maatregel of een autonoom proces?

In essentie worden twee hoofdvragen met betrekking tot de boomkorvisserij in de Voordelta tussen 2004-2015 behandeld:

1) Hoe groot was de onttrekking van vis en garnaal door de platvis- en garnalenkotters voor en na de instelling van het BBG en wat is het effect van deze onttrekking geweest op de omvang van de commerciële bestanden?

2) Wat zijn de oorzaken van de verminderde platvisvisserij in de Voordelta?

\section{$1.3 \quad$ Methodiek}

Voor de eerste vraag wordt bestaande informatie over visserij-inspanning, aanlandingen en discards (niet-aangelande vis) van de platvis- en garnalenkotters geanalyseerd. Hieruit worden voor zover mogelijk tijdreeksen geconstrueerd voor de periode 2004-2015 van de totale hoeveelheid onttrokken vis voor de commercieel meest belangrijke soorten in de Voordelta van de twee visserijen (minimaal 95\% van de aanlandingen). Deze worden afgezet tegen ICES ${ }^{3}$-schattingen van de bestandsgrootte; waar mogelijk in de Voordelta en anders op de schaal waarop het bestand zich bevindt (Noordzee of groter). Als er geen absolute bestandsschattingen beschikbaar zijn voor een bestand, dan wordt gebruik gemaakt van bestandsontwikkelingen. De details van hoe deze schattingen tot stand zijn gekomen staan in hoofdstuk 6 . Hiermee wordt dus het effect van de onttrekking op de omvang van de bestanden geschat.

Voor de tweede vraag is naast analyse van logboek- en VMS-gegevens ook een sociologische studie verricht naar de beweegredenen van de platvisvissers om minder in het gebied te vissen.

\subsubsection{Analyse van logboek- en VMS-gegevens}

De basis van de analyses wat betreft de hoeveelheid visserij-inspanning en aanlandingen zijn de VMSen logboekgegevens van de schepen. Een uitleg van deze gegevens en de methodiek van opwerking is beschreven in Hintzen et al. (2013). De methodiek is ook uitgebreid beschreven in de eerste PMR-fase (Prins et al. 2014) en betreft een standaardmethodiek om VMS- en logboekgegevens op te werken naar aanlandingen per 'vissend VMS-ping'. Per type visserij wordt de meest waarschijnlijke bandbreedte van vaarsnelheden bepaald, waarmee gevist wordt. Vervolgens worden de aanlandingen van die visreis evenredig verdeeld over alle 'vissende VMS-pings'. Deze gegevensset is beschikbaar vanaf 2004 voor de meeste visserijen.

\footnotetext{
${ }^{3}$ The International Council for the Exploration of the Sea. Het internationale instituut dat de commerciële bestanden in de Noordzee evalueert.
} 


\section{Definitie visserijen}

De twee visserijen die in dit rapport van het grootste belang zijn, zijn de platviskotters en de garnalenkotters. De overige visserijen worden op een hoger niveau gedefinieerd. De tuigtypes zoals deze in de VMS en logboek databases worden gebruikt zitten op de volgende manier hierin verwerkt:

1. Boomkorvisserij: Tuig $=$ TBB

a. Garnalenvisserij ( $<300 \mathrm{PK}$ )/garnalenkotters: met een vermogen van $<=225 \mathrm{~kW}$ en maaswijdtes 15-32 mm.

b. Platvisvisserij (260-300PK)/platviskotters: met een vermogen van 191-225 kW

c. Platvisvisserij ( $>300 \mathrm{PK}$ ): met een vermogen van $225<\mathrm{kW}<=1000$

d. Platvisvisserij (<260PK): met een vermogen $<191 \mathrm{~kW}$.

2. Schelpdiervisserij: Tuig $=$ DRB HMD

3. Bordenvisserij: Tuig = OTB OTM PTB OTT

4. Staandwant: Tuig $=$ GTR GNS

5. Schotse zegen: Tuig = SSC

6. Fuikenvisserij: Tuig $=$ FPO

\section{Data per analyse}

De beschikbaarheid van logboek- en VMS-gegevens kan sterk verschillen tussen typen visserij. Jaren worden pas meegenomen als de beschikbare gegevens als representatief worden ingeschat (Hintzen et al. 2013). Voor de platviskotters en garnalenkotters zijn representatieve inspanningsgegevens beschikbaar vanaf 2004. Echter, pas vanaf 2006 zijn voor de garnalenvloot logboeken beschikbaar, waarmee ook pas vanaf 2006 de controlestap door te voeren was om te bepalen of een schip werkelijk tot de garnalenvloot behoorde. Voor de bordenvisserij zijn de gegevens vanaf 2005 representatief en voor de schelpdiervisserij pas vanaf 2009.

Wel zijn voor de platviskotters logboekgegevens vanaf 1995 beschikbaar, waarmee trends in aanlandingen van deze vloot over een langere tijdspan bekeken kunnen worden. Deze logboekgegevens zijn op het niveau van ICES-kwadranten. Hierbij ligt de Voordelta voornamelijk in kwadrant 32F3 (Figuur 0-1). Dit kwadrant is dan ook als proxy genomen voor de lange-termijn ontwikkelingen in de aanlandingen van de platviskotters.

Uit deze standaard gegevensset zijn een aantal basisparameters gedistilleerd:

1. Inspanning wordt uitgedrukt als het aantal uur waarop gevist wordt ('visuur')

2. Aanlanding wordt uitgedrukt als het aantal ton $(1000 \mathrm{~kg})$ aanlanding

3. Vangstsucces is het aantal ton vangst per visuur. Voor het jaargemiddelde van het vangstsucces wordt de mediaan genomen over alle vissende VMS-pings ${ }^{4}$.

Voor de platvisvisserij wordt in meer detail naar de visserij-ontwikkelingen gekeken. Zo wordt naar trends op grotere ruimtelijke en temporele schalen gekeken, als ook naar veranderingen in havengebruik, de invloed van de pulskor en seizoenspatronen.

\subsubsection{Analyse van discards}

Voor het bepalen van de hoeveelheid discards (niet-aangelande vangsten) is gebruik gemaakt van alternatieve gegevensbronnen, namelijk discardmonitoringsprogramma's, het garnalenexperiment uitgevoerd in het kader van PMR (Schellekens et al., 2014) en het discardexperiment uitgevoerd binnen de studie naar de effecten van de garnalenvisserij in Natura-2000-gebieden (Glorius et al. 2015). De laatste twee experimenten zijn meegenomen, omdat binnen de standaard discardmonitoringsprogramma's wat betreft de garnaalvisserij minder dan $0.5 \%$ van de totale

\footnotetext{
${ }^{4}$ De manier van gegevens opwerken heeft hierbij wel een grote invloed op de berekening van het vangstsucces. Het vangstsucces per vissende VMS-ping vertoont bijvoorbeeld een sterk niet-normale verdeling met veel zeer lage waardes en een klein aantal uitschieters met hoge waardes.
} 
vangstinspanning van de garnalenvloot wordt bemonsterd. Binnen de Voordelta was het aantal beschikbare monsters dan ook zeer laag - in meerdere jaren zelfs nihil.

\section{Discard monitoring programma's}

Voor het bepalen van de hoeveelheid discards is gebruik gemaakt van gegevens uit de demersale discardmonitoring die onder de wettelijke onderzoekstaken uitgevoerd wordt door Wageningen Marine Research. In Europa wordt de discardmonitoring onder het Data Collection Framework (DCF) gecoördineerd. Deze discardmonitoring wordt al sinds 2002 op een gestandaardiseerde manier uitgevoerd. De methodiek en focus van dit programma hebben echter over de jaren enkele veranderingen doorgemaakt:

Tussen 2002 en 2009 werden er ieder jaar 10 waarnemersreizen in de platvisvisserij in de Noordzee uitgevoerd. Hierbij gaan waarnemers van Wageningen Marine Research mee met een commercieel vissersschip en proberen zij iedere trek een monster te nemen van de discards. Na 2009, onder een hervorming van het DCF, wordt een zelfbemonsteringsprogramma met minimaal 160 visreizen in samenwerking met de visserijsector uitgevoerd (zelfbemonsteringsreizen) naast de 10 waarnemersreizen. Dit heeft de ruimtelijke spreiding van de bemonstering aanzienlijk vergroot.

Binnen de discardmonitoring van de garnalenvisserij worden er ieder jaar 8 reizen in de Noordzee uitgevoerd. Deze discardmonitoring is opgezet in 2008. Tijdens de discardmonitoring gaan waarnemers van Wageningen Marine Research mee met een commercieel vissersschip en proberen zij iedere trek een monster te nemen van de vangst.

In de Voordelta zijn vrijwel geen discardreizen geweest. Daarom is met aannames gewerkt, om toch een grove schatting van de hoeveelheid discards te verkrijgen. Deze aannames zijn hieronder uiteengezet.

\section{Missende informatie en aannames}

Voor de platvisserij waren geen monsters beschikbaar uit de Voordelta. Om toch een schatting te kunnen maken van de hoeveelheid discards in de Voordelta moet gewerkt worden met informatie uit omliggende gebieden en aannames. We nemen daarom aan dat een gelijkwaardige visserij actief is in de 'ICES-rectangle' waarin de Voordelta valt (32F3) en de omliggende rectangles (33F3, 33F4, 31F3) als in de Voordelta (Figuur 0-1). Uit deze rectangles zijn namelijk wel monsters beschikbaar voor de analyse (Tabel 0-1). Dit betekent dat we aannemen dat de verhouding tussen inspanning en discards gelijk is in de Voordelta en de omliggende gebieden. Deze omliggende gebieden zijn de twee kustrectangles ten noorden en zuiden van de Voordelta, en de rectangle ten westen (dus verder kust afwaarts).

Daarnaast is voorafgaand aan 2010 geen informatie over deze vier gebieden beschikbaar. Voor de jaren 2004-2009 wordt daarom gebruikt gemaakt van de data 2010 - 2015: de gemiddelde hoeveelheid discards per uur over 2010-2015 wordt gebruikt om de discards in 2004-2009 te schatten. Hierdoor wordt aangenomen dat de verhouding tussen inspanning en discards gelijk blijft door de tijdserie heen.

In de discardbemonstering worden geen gewichten van het benthos berekend en geen lengtes genoteerd. De monitoring noteert alleen aantallen. Voor deze analyse zijn de gemiddelde gewichten (in asvrij drooggewicht) per benthossoort uit een andere monitoring gebruikt, namelijk de benthossurvey van PMR met zowel schaaf als boxcorer. Deze gewichten per benthossoort zijn bekend voor zes jaren tussen 2004 -2015; 2004, 2005, 2009, 2010, 2011 en 2012. De gemiddelde gewichten over deze jaren zijn vermenigvuldigd per soort met de benthosaantallen uit de discardbemonstering. Hierbij is geen rekening gehouden met het feit dat de benthosmonitoring alle individuen vangt en de platvisvisserij alleen de grootste individuen. Hierdoor krijgen we het gewicht per uur gediscard, analoog aan de analyse voor de vissoorten. Deze schattingen zijn dus minimale schattingen, aangezien (a) het alleen het asvrij drooggewicht betreft en (b) de gemiddelde gevangen lengte in de PMR-survey veel lager ligt dan in de platvisvisserij.

Voor de garnalenvisserij zijn wel discardreizen in de Voordelta beschikbaar, maar alleen in 5 van de 12 jaar en maar 1-2 reizen per jaar (Tabel 0-1). In de opwerkingen wordt aangenomen dat 1-2 reizen per 
jaar representatief zijn voor de gehele garnalenvisserij, en dat de verhouding tussen inspanning en discards gelijk blijft tussen jaren. Met deze laatste aanname kan de gemiddelde hoeveelheid discards per uur in de beschikbare jaren worden gebruikt om de discards de overige jaren te schatten. Benthos wordt in de discardreizen van de garnalenvisserij niet zodanig bemonsterd dat schattingen opgewerkt kunnen worden. Alleen discards qua garnaal wordt wel bemonsterd.

In welke mate deze aannames kloppen is onbekend en al deze aannames zullen grote consequenties hebben voor de uiteindelijke schattingen. De geschatte hoeveelheden discards in de Voordelta moeten daarom ook als zeer grove indicatie worden gezien. Boven op de ruime aannames wat betreft alle discardopwerkingen, heeft de benthos-opwerking van de platvisvisserij aanvullende grote aannames. Deze opwerking is dan ook het minst betrouwbaar en kan niet direct met de andere schattingen vergeleken worden.

Tabel 0-1: Aantal beschikbare monsters in Voordelta en zuidelijk deel van de Noordzee (gebied 4, deelgebied 4c) vanuit het $D C F$.

\begin{tabular}{|c|c|c|}
\hline & garnalenvisserij & $\begin{array}{c}\text { platvisvisserij } \\
260-300 \mathrm{PK}\end{array}$ \\
\hline 2004 & Voordelta & $\begin{array}{c}32 \mathrm{~F} 3-33 \mathrm{~F} 3-33 \mathrm{~F} 4- \\
31 \mathrm{~F} 3\end{array}$ \\
\hline 2005 & - & - \\
\hline 2006 & - & - \\
\hline 2007 & - & - \\
\hline 2008 & - & - \\
\hline 2009 & 1 & - \\
\hline 2010 & - & - \\
\hline 2011 & - & 14 \\
\hline 2012 & 2 & 8 \\
\hline 2013 & - & 19 \\
\hline 2014 & 1 & 16 \\
\hline 2015 & 1 & 25 \\
\hline
\end{tabular}

\section{Garnalenexperiment PMR}

Bij de instelling van het BBG is afgesproken nader onderzoek te doen naar de specifieke effecten van garnalenvisserij op de bodem-habitats in de Voordelta (Schellekens et al. 2014). Dit onderzoek is 3 jaar lang (2010-2012) uitgevoerd in zes maanden (in mei-november). Het onderzoek was opgezet als een BACI-experiment: in de Voordelta werden zes proefvakken verdeeld in een experimenteel te bevissen deelgebied, en een niet te bevissen controlegebied. Aan de uitvoering van deze experimentele visserij is qua visgedrag en vistuig niets aangepast en de bevissing is daarmee uitgevoerd alsof het een gewone commerciële visserij betrof, behalve dat de zeeflap is dichtgebonden, waardoor ook de grotere vissen gevangen werden. Bij het experimenteel vissen werden zes maal per jaar in de lengte van het proefvak zes trekken achter elkaar uitgevoerd, over de hele lengte van het gebied. Alle vangsten per trek werden onmiddellijk na het aan dek halen uitgezocht en alle organismen gedetermineerd en geteld. Meer uitleg over de opzet en uitvoering van het onderzoek is te vinden in Appendix A1.1.

Ten behoeve van de analyses in dit rapport zijn alle vangsten per trek omgerekend naar vangsten per visuur. Hierbij zijn een aantal keuzes in de selectie van gegevens gemaakt, omdat getracht wordt op basis van dit experiment een beeld van de vangstsamenstelling van de commerciële garnalenvisserij te krijgen. Garnalenvisserij wijkt in een aantal opzichten af van het uitgevoerde experiment:

i. In het experiment wordt een gebied zes keer direct opeenvolgend bevist, terwijl in de commerciële visserij dit niet gebruikelijk is. De vangstsamenstelling tijdens de opeenvolgende trekken per vak laten duidelijk een afnemende trend zien voor garnaal, platvis en demersale vis (Schellekens et al 2014). Daarom is voor de 
analyses in dit rapport alleen gebruik gemaakt van de vangstsamenstelling in de eerste twee trekken.

ii. In het experiment was de zeeflap dichtgebonden, terwijl in de commerciële visserij de zeeflap verplicht is. De bedoeling van de zeeflap is om de grotere vissen te laten ontsnappen uit de netten. Hierbij is de aanname dat vissen groter dan 10 $\mathrm{cm}$ kunnen ontsnappen (Catchpole et al. 2008). Daarom zijn alle vissen groter dan $10 \mathrm{~cm}$ niet in de analyses meegenomen. Voor garnalen is onderscheid gemaakt tussen maatse en ondermaatse garnalen (grens: $50 \mathrm{~mm}$ ).

\section{Garnalendiscards in N2000 gebieden}

In een studie naar de effecten van de garnalenvisserij in Natura-2000-gebieden (Glorius et al. 2015), is jaarrond onderzoek gedaan naar de bijvangst in de Nederlandse garnaalvisserij in Natura-2000gebieden. Hierbij is een gestratificeerde selectie gemaakt van commerciële schepen die samen een referentievloot vormden. Deze schepen zijn tussen juni 2012 en juni 2014 bemonsterd, waarbij vissers zelf hun visdiscards hebben verzameld, welke vervolgens zijn geanalyseerd door Wageningen Marine Research. De bemonsteringsopzet was niet geschikt voor het schatten van alle soorten bijvangst: zo kan de hoeveelheid ondermaatse garnaal en meerdere vissoorten zoals grondels, smelt en andere kleinere vissoorten niet representatief geschat worden.

De gegevens zijn opgewerkt naar gemiddeld vangstsucces (aantal per uur) per kwartaal, over de 24 maanden heen. In de Voordelta zijn gegevens van drie schepen beschikbaar, met 54 trekken in 36 reizen, zie Tabel 0-2. Het geschatte vangstsucces per kwartaal wordt hier als schatting voor de jaren 2012-2014 genomen. Hierbij is alleen naar soorten gekeken die als representatief bemonsterd worden beschouwd.

Tabel 0-2 Aantal geschikte trekken in Voordelta per kwartaal en jaar in het zelfbemonsteringsprogramma

\begin{tabular}{lllll} 
jaar & \multicolumn{4}{c}{ kwartaal } \\
& $\mathbf{1}$ & $\mathbf{2}$ & $\mathbf{3}$ & $\mathbf{4}$ \\
$\mathbf{2 0 1 2}$ & & & 5 & 9 \\
$\mathbf{2 0 1 3}$ & 3 & 17 & 12 & 3 \\
$\mathbf{2 0 1 4}$ & 5 & & &
\end{tabular}

\subsubsection{Sociologische studie}

Om de oorzaken van de verminderde platvisvisserij te achterhalen is naast een analyse van de visserijgegevens ook een sociologische studie verricht, waarbij 6 vissers en 2 informanten uit de Voordelta zijn geïnterviewd. De vissers waren geselecteerd omdat ze tussen 2004 en 2007 in de Voordelta op platvis hebben gevist. In Appendix A.1.2 wordt de structuur van de interviews en de opwerking van de gegevens beschreven.

\section{$1.4 \quad$ De Voordelta}

De Voordelta is het gebied bestaand uit de ondiepe kustwateren voor de delta van ZuidHolland en Zeeland (Prins et al. 2014). Het betreft ruwweg het gebied vanaf de Westerscheldemonding tot aan de Nieuwe Waterweg. Aan de zeezijde volgt de grens de doorgaande 20 meter dieptelijn en ligt bijna tegen de 6-mijlijn aan (Figuur 0-1). De Voordelta is sinds 2008 een Natura-2000-gebied en het grootste deel (ruim 87.000 ha na aanleg van Maasvlakte2) is gekarakteriseerd als $\mathrm{H} 1110$, permanent overstroomde zandbanken. Een klein deel (ongeveer 2.200 ha) bestaat uit slik- en zandplaten. Door de ligging voor de Zuid-Hollandse en Zeeuwse delta wijkt het gebied af van de kustwateren die verder noordelijk voor de Hollandse kust liggen. Het gebied wordt gekenmerkt door de aanwezigheid van een gevarieerd en dynamisch milieu van kustwateren, intergetijdengebied (zandplaten en slikken) en stranden, die een relatief beschutte overgangszone vormen tussen de (voormalige) estuaria en de volle zee. 


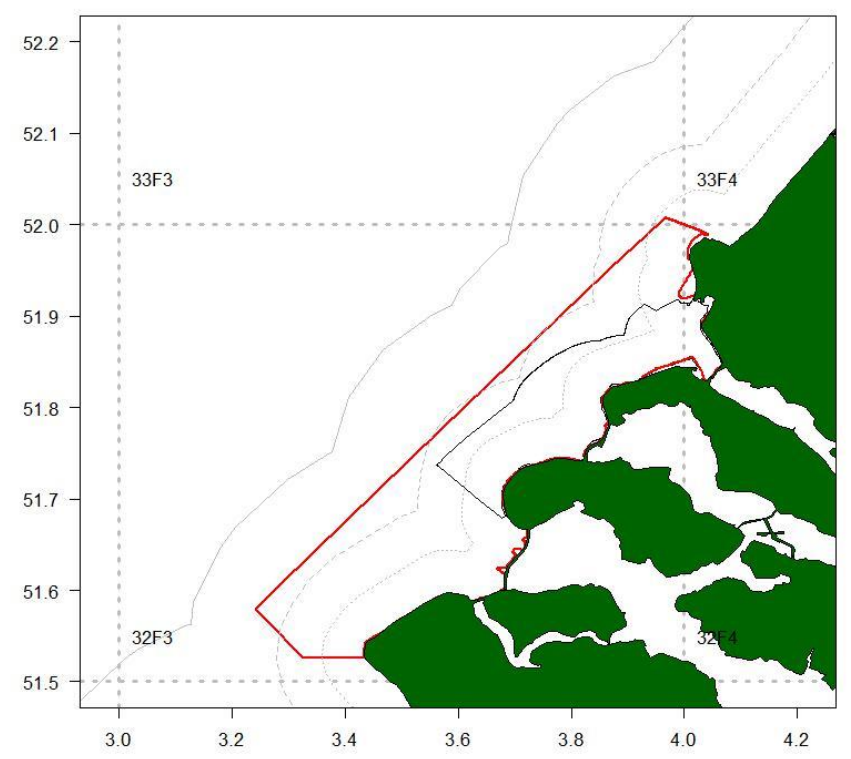

Figuur 0-1 De Voordelta (in rood) en het Bodembeschermingsgebied (in zwart), in relatie tot de ICESkwadranten (de grote vierkanten in stippelijn. De Voordelta ligt hoofdzakelijk in ICES-kwadrant 32F3) en de 12-mijlgrens (doortrokken grijze lijn), de 6-mijlgrens (gestreepte grijze lijn) en de 3-mijlgrens (gestippelde grijze lijn).

\subsection{Opbouw rapport}

In hoofdstuk 2 wordt een overzicht van de gehele visserij in de Voordelta gegeven, om de boomkorvisserij in perspectief te plaatsen. In hoofdstuk 3 worden de belangrijkste ontwikkelingen in de inspanning van de platviskotters en garnalenkotters uiteengezet. Hoofdstuk 4 behandelt de trends in hoeveelheid aanlandingen en in het vangstsucces. In hoofdstuk 5 wordt de informatie over de discards zover als mogelijk samengevoegd tot tijdreeksen. In hoofdstuk 6 wordt de impact van de visserij-onttrekking op de commerciële bestanden onderzocht. In hoofdstuk 7 wordt onderzoeksvraag 1 behandeld en wordt de beschikbare informatie over de commercieel onttrokken vis en benthos samengevat in de periode voor en na de instelling van het BBG. Ook wordt waar mogelijk het effect op de commerciële bestanden berekend voor deze periodes. In hoofdstuk 8 worden de uitkomsten van de interviews met de vissers beschreven. In hoofdstuk 9 wordt onderzoeksvraag 2 behandeld: aan de hand van de tijdreeksen en de sociologische studie wordt geëvalueerd welke oorzaken voor de verminderde platvisvisserij het meest logisch zijn. In hoofdstuk 10 worden de belangrijkste conclusies samengevat. 


\section{Visserij in de Voordelta}

\subsection{De Nederlandse vloot in de Voordelta}

\subsubsection{Typen visserij}

De visserij in de Voordelta is onder te verdelen in acht categorieën; boomkorschepen vissend op platvis (<260 en 260-300 PK), boomkorschepen vissend op garnaal, de schelpdiervisserij, bordenvisserij, staandwantvisserij, schotse zegenvisserij en fuikenvisserij ${ }^{5}$. Hieronder volgt een korte beschrijving van deze visserijtypen.

1. Platvisvisserij: Een boomkorschip trekt twee sleepnetten over de zeebodem waarbij de doelsoorten bestaan uit platvis. De netten worden opengehouden door een stalen balk, de boom. Aan de uiteinden van deze boom zitten zware stalen glijders (sloffen, een soort sleeën) die over de zeebodem glijden. Aan deze glijders zijn meerdere rijen kettingen (wekkerkettingen) bevestigd, die over de grond slepen en zo de platvis uit het zand op laten schrikken. De glijders en wekkerkettingen veroorzaken bodemberoering. De doelsoorten Noordzeebreed zijn schol en tong (Prins et al. 2014).

a. 260-300 PK. Deze schepen zijn het voornaamste studieonderwerp van dit rapport en worden hier de platviskotters genoemd. De boomkor en kettingen zijn gemiddeld 4.5 meter breed. Een schip trekt zodoende in totaal 9-meter-breed tuig voort.

b. <260 PK. De platvisschepen met een motorvermogen van minder dan 260 PK komen vrijwel niet voor in de Voordelta.

Binnen de platvisvisserij is de enige innovatieve tuigontwikkeling die invloed op de vangstsamenstelling kan hebben de puls; een elektrische puls genererend tuig dat veel minder brandstof vergt maar ook, vooral rondom de introductiefase, resulteerde in een lagere vangst en andere vangstsamenstelling. Er wordt door een deel van de vloot vanaf 2009 gevist met puls, en in de Voordelta vanaf 2011.

2. Garnalenvisserij: Bij garnalen(boom)korren wordt net als bij de gewone boomkor aan iedere kant van het schip een net voortgesleept over de bodem. Garnalenkorren zijn lichter in gewicht dan boomkorren. Bovendien zijn deze niet voorzien van wekkerkettingen, maar van klossenpezen die over de bodem rollen. Hierdoor is de bodemberoering minder groot dan bij boomkorren. De breedte van een garnalenkor is 9 meter. Doelsoort is garnaal en er wordt weinig grote vis bijgevangen, door een verplichte zeeflap die vissen groter dan ca $10 \mathrm{~cm}$ weert (Prins et al. 2014). Deze schepen worden hier garnalenkotters genoemd. Ook in de garnalenvisserij is het pulstuig geïntroduceerd, maar pas in 2015 in de Voordelta.

3. Schelpdiervisserij: Visserij waarbij met behulp van zuigkorren strandschelpen (Spisula) en zwaardschedes (Ensis) van de bodem worden gezogen. Het sediment wordt hierbij eerst tot een diepte van $30 \mathrm{~cm}$ in de bodem uitgezeefd, waarna de schelpdieren door water of lucht via zuigbuizen worden opgezogen aan boord. Zwaardschede is de belangrijkste doelsoort van de Nederlandse schelpdiervisserij in de Noordzeekustzone. Bovendien mag binnen een Natura2000-gebied zoals de Voordelta niet op strandschelpen gevist worden, maar wel op zwaardschede.

4. Bordenvisserij: Bij bordenvisserij worden bordentrawls gebruikt. Dit zijn netten waarbij aan de zijkanten scheerborden zijn bevestigd (Prins et al. 2014; Eigaard et al. 2016). Bij verplaatsing door het water scheren de borden naar buiten waardoor het net in de breedte wordt opengetrokken. Moderne vistuigen, zoals twin- of multirigging maken ook gebruik van scheerborden. De bordentrawl schraapt over de zeebodem. Bodemberoering wordt hier vooral veroorzaakt door de scheerborden. De sporen zijn meestal minder dan een meter breed en daarmee veroorzaken ze bodemberoering over een veel smaller spoor dan bij boomkorren.

\footnotetext{
${ }^{5} \mathrm{Er}$ is ook geregistreerde visserij die niet binnen deze categorieën valt; pelagische visserij die soms aan de randen van de Voordelta plaatsvindt, lijnvisserij en -met name- visserij zonder logboekgegevens over het type visserij ('missing'). Deze zijn hier niet meegenomen.
} 
5. Staandwant: Staandwantvisserij in de Nederlandse kust richt zich op tong, zeebaars, harder en kabeljauw en tarbot en griet (Jongbloed et al. 2014). Tongvisserij gebruikt netten met maaswijdtes van $90-100$ mm en netlengtes van ca. 10 - 25 kilometer. Zeebaars- en hardervisserij gebruikt netten van 90-130 mm en netlengtes van ca. 50 - 250 meter. Kabeljauwvisserij vindt plaats met maaswijdtes groter dan $130 \mathrm{~mm}$ en netlengtes van ca. 50 meter - 5 kilometer. Tarbot en griet wordt als bijvangst gevangen in de kabeljauw- en tongvisserij. Staandwantvisserij vindt met name plaats langs de kust tussen IJmuiden en Hoek van Holland, maar alle drie de visserijen vinden ook plaats in de Voordelta (Jongbloed et al. 2014).

6. Schotse zegenvisserij: De schotse zegenvisserij is een hybride tussen zegenvisserij en bordenvisserij (Eigaard et al. 2016). Het schip beweegt voorwaarts en trekt tegelijkertijd de zegen in, welke meestal aan een boei bevestigd is. De zegen beweegt dus sneller dan het schip en de zegenlengte is meestal 4-6 km.

7. Korfvisserij: Korven bestaan uit een raamwerk van geknoopt netwerk of ander materiaal, met inkepingen waardoor vis of schaaldieren erin kunnen komen, maar niet eruit. Vaak worden ze in een serie op de zeebodem geplaatst.

\subsubsection{Inspanning per type visserij}

In Tabel 0-3 wordt de totale inspanning per jaar voor de Nederlandse visserijen in de Voordelta gegeven. De inspanning van de actieve visserijen is gebaseerd op gedetailleerde logboek- en VMSgegevens uit de Voordelta en is weergegeven in de standaardeenheid van dit rapport; het aantal uren dat een schip gevist heeft (visuren). De inspanning van de passieve visserijen kan niet zo gedetailleerd opgewerkt worden, omdat er op basis van de VMS-gegevens geen definitie van vissen en niet-vissen gegeven kan worden (vissende schepen liggen stil). Er zijn dus alleen logboekgegevens beschikbaar; dit is informatie op het ruimtelijk niveau van ICES-kwadrant en op het temporele niveau van de hoeveelheid dagen dat een schip op zee is binnen een visreis (zeedagen). Voor visserijen als korf- en staandwantvisserij is een zeedag ook een goede indicatie voor de visserij-intensiteit aangezien dit type tuig waarschijnlijk maximaal 1 keer per dag wordt gezet/gehaald. Voor de passieve visserijen kan dus geen inspanningsinformatie op hetzelfde detailniveau worden gegeven. In de staandwantvisserij zijn veel vissers actief, waarin ongeveer 100 schepen ieder jaar deelnemen. Echter, een hoop van deze schepen is maar enkele dagen per jaar actief, vergeleken met de platvis- en garnalenvisserij waar vissers jaarrond operatief zijn.

De meest intensieve actieve bevissing in de Voordelta door de Nederlandse vloot in 2004-2015 vindt plaats door de garnalenvisserij. Deze visserij neemt sterk toe door de jaren heen (Figuur 0-2). Zo is de inspanning in 2015 verdubbeld ten opzichte van 2010-2011. De platviskotters die sinds 2008 uit het BBG verbannen zijn (met 260-300 PK) waren alleen in 2004 de grootste visserij, maar hebben sindsdien nog steeds een van de grootste inspanning in de Voordelta - ondanks de sterke afname door de jaren heen. Platvisvisserij met klein motorvermogen ( $<260 \mathrm{PK}$ ) komt weinig voor in de Voordelta. Van de platvisvisserij tussen 2004 en 2007 is deze kleine platvisvisserij ook maar verantwoordelijk voor $1.3 \%$ van de inspanning, en de platviskotters met $260-300$ PK voor $98.7 \%$. Passieve bevissing met behulp van korven neemt sterk toe in de Voordelta (Figuur 0-3). 
Tabel 0-3 Inspanning per type visserij in de Voordelta. Voor de actieve visserijen; aantal visuren in de Voordelta. Voor de passieve visserijen: aantal zeedagen in ICES-kwadrant 32F3 (waar de Voordelta grotendeels binnenvalt, zie Figuur 0-1). '-': geen representatieve gegevens beschikbaar.

\begin{tabular}{|c|c|c|c|c|c|c|c|c|c|c|c|c|c|}
\hline & 2004 & 2005 & 2006 & 2007 & 2008 & 2009 & 2010 & 2011 & 2012 & 2013 & 2014 & 2015 & Totaal \\
\hline \multicolumn{14}{|c|}{ ACTIEF (visuren Voordelta) } \\
\hline Garnalenvisserij & 8863 & 7054 & 19727 & 15583 & 14617 & 12225 & 12546 & 12862 & 17732 & 18467 & 19094 & 25932 & 184700 \\
\hline platvisvisserij 260-300 & 9215 & 5642 & 3883 & 3936 & 2822 & 2161 & 1099 & 1663 & 1610 & 1600 & 801 & 1705 & 36138 \\
\hline Schelpdiervisserij & - & - & - & - & - & 1554 & 288 & 293 & 675 & 2034 & 2889 & 1714 & 9447 \\
\hline Bordenvisserij & - & 270 & 103 & 95 & 160 & 964 & 403 & 81 & 88 & 35 & 19 & 55 & 2271 \\
\hline platvisvisserij $<260$ & 73 & 106 & 18 & 96 & 122 & 32 & 8 & 95 & 62 & 151 & 52 & 186 & 1000 \\
\hline schotse zegenvisserij & 0 & 0 & 0 & 10 & 1 & 22 & 54 & 25 & 0 & 24 & 19 & 4 & 157 \\
\hline \multicolumn{14}{|l|}{ PASSIEF (zeedagen 32F3) } \\
\hline Korfvisserij & 232 & 105 & 33 & 51 & 33 & 169 & 386 & 311 & 412 & 566 & 807 & 650 & 3754 \\
\hline staandwantvisserij & 123 & 181 & 287 & 177 & 177 & 177 & 69 & 53 & 71 & 92 & 129 & 149 & 1684 \\
\hline
\end{tabular}

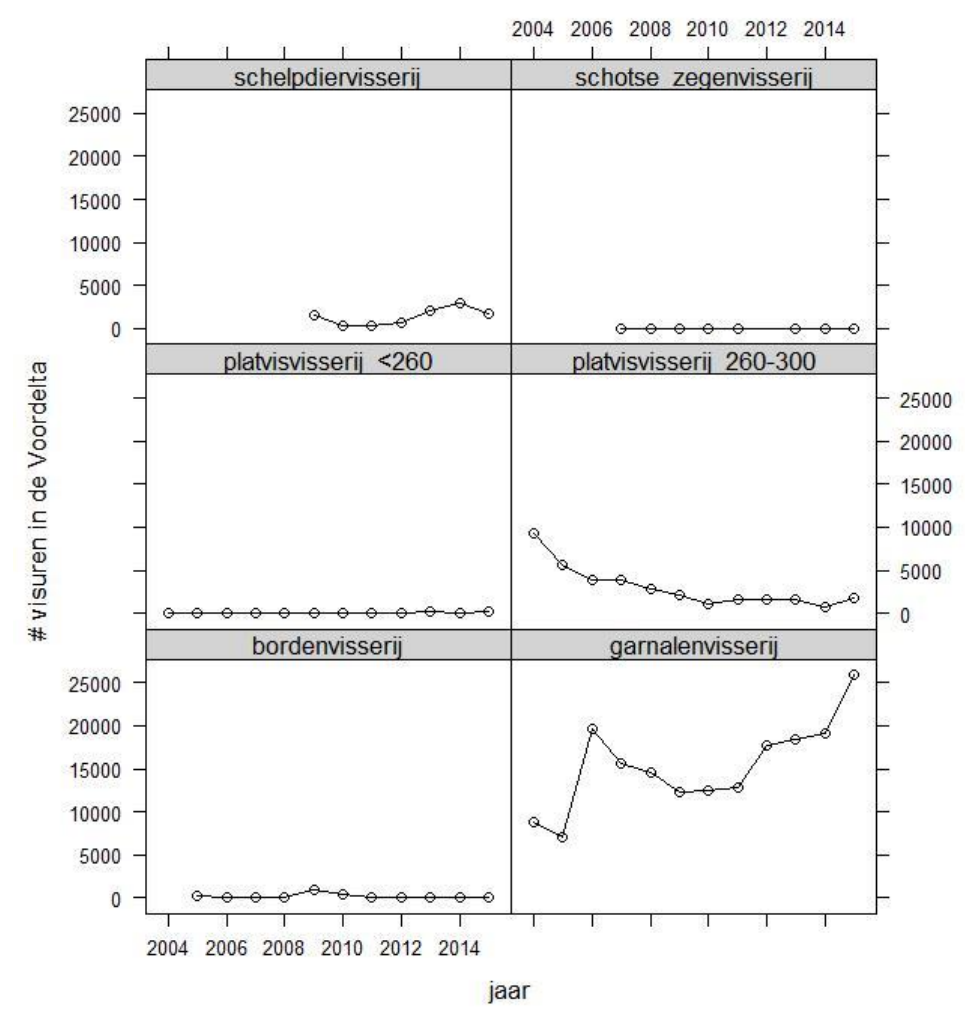

Figuur 0-2 Inspanning per type visserij in de Voordelta, voor de actieve visserijen; aantal visuur in de Voordelta. 


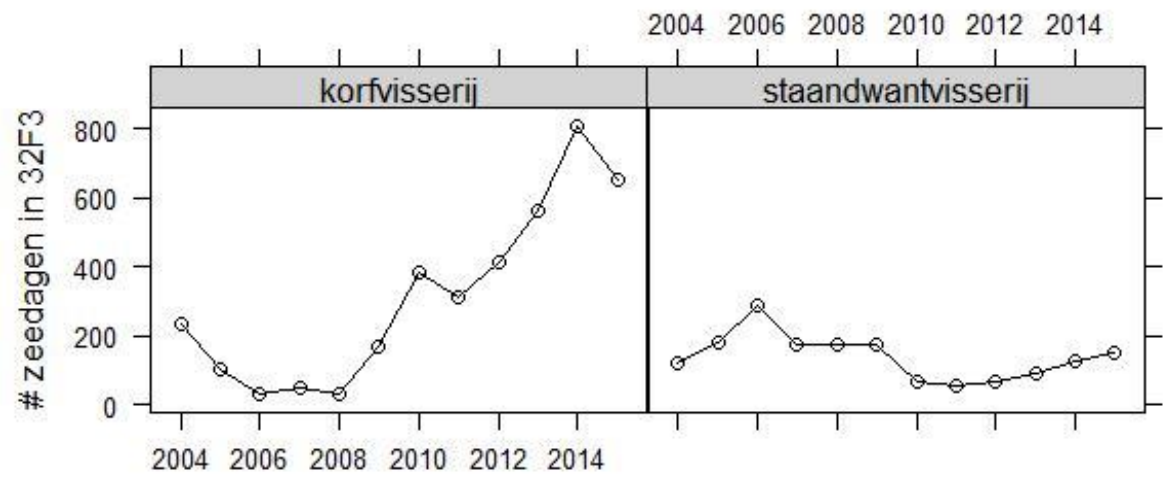

jaar

Figuur 0-3 Inspanning per type visserij in de Voordelta, voor de passieve visserijen: aantal zeedagen in ICES-kwadrant $32 F 3$.

\subsubsection{Ruimtelijke verspreiding van de visserijen}

Op basis van de VMS-gegevens is de verdeling van de inspanning over de Voordelta berekend. Hierbij is de gemiddelde inspanning over 2004-2015 berekend per kilometer-gridcel. Wat betreft de staandwant- en de korfvisserij betreffen de gegevens alleen het voorkomen van de schepen, niet vissende activiteit zoals bij de andere visserijen (want als ze vissen, liggen de schepen stil). Soms gebruiken ze in deze twee visserijen een moederschip (met VMS) en kleine satellietschepen waarmee gevist wordt. Voor deze twee visserijen is de ruimtelijke verdeling dus een grove benadering.

Er is een groot verschil in ruimtelijke verspreiding tussen de typen visserij (Figuur 0-4). Platvisvisserij $<260$ PK en korfvisserij vinden vrijwel uitsluitend plaats bij de monding van het Haringvliet.

Staandwant- en Schotse zegenvisserij vinden hoofdzakelijk langs de diepere randen van de Voordelta plaats (en meer landafwaarts). Platvisvisserij 260-300 PK (de platviskotters) lijkt het zwaartepunt qua inspanning iets meer landafwaarts dan de Voordelta te hebben, maar met alsnog inspanning in de Voordelta (in de gebieden waar nog gevist mag worden). Bordenvisserij vindt vooral in de noord-en zuidhoek van de Voordelta plaats. Schelpdier- en met name garnalenvisserij heeft de grootste inspanning daadwerkelijk in de Voordelta. Garnalenvisserij concentreert zich hierbij met name in het BBG. 

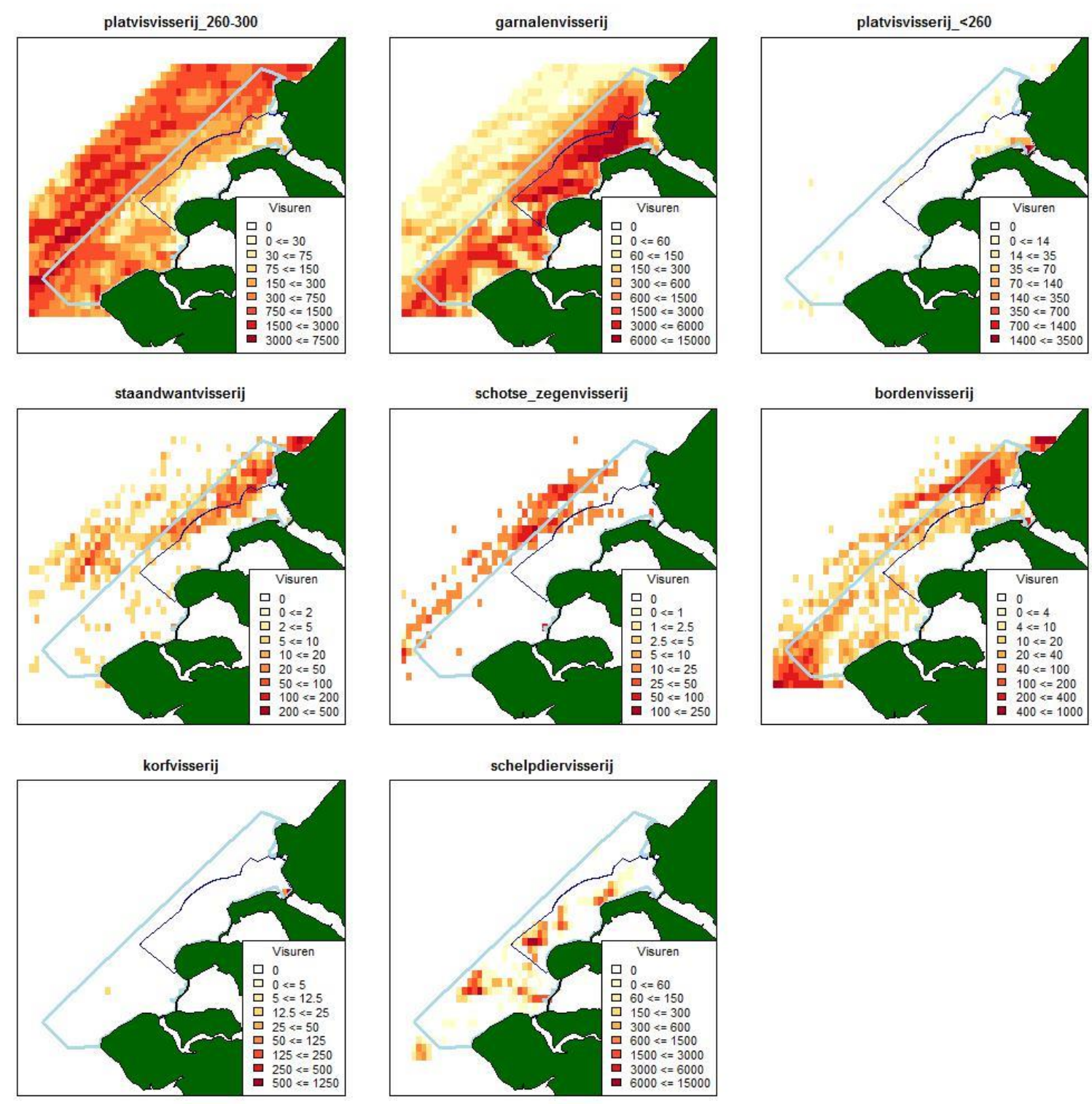

Figuur 0-4 Ruimtelijke verdeling van de gemiddelde jaarlijkse inspanning (in visuren) per $1 \mathrm{~km}$ gridcel van alle typen visserij in de Voordelta (licht blauw omlijnd) en het BBG (donkerblauw omlijnd) tussen 2004 en 2015.

\subsubsection{Aantal schepen per type visserij}

Het aantal schepen per jaar verandert scherp voor sommige typen visserij (Figuur 0-5); zo neemt het aantal actieve schepen in de fuikenvisserij toe sinds 2009, terwijl het aantal actieve schepen in de staandwantvisserij en de platvisvisserij (260-300 PK) juist afneemt.

De grote hoeveelheid inspanning van de schelpdiervisserij komt voor rekening van een klein aantal schepen; er zijn vier schepen die dit type visserij bedrijven in de Voordelta. Van deze schepen vissen twee schepen in de meeste jaren ( $8 / 9$ jaar), terwijl drie schepen maar in enkele jaren $(<=3$ jaar) vissen. Dezelfde patronen bestaan bij de andere visserij; veel schepen vissen maar in enkele jaren van de tijdreeks (vergelijk het totaal aantal schepen in Tabel 0-4 met het aantal schepen per jaar in Figuur 0-5). 


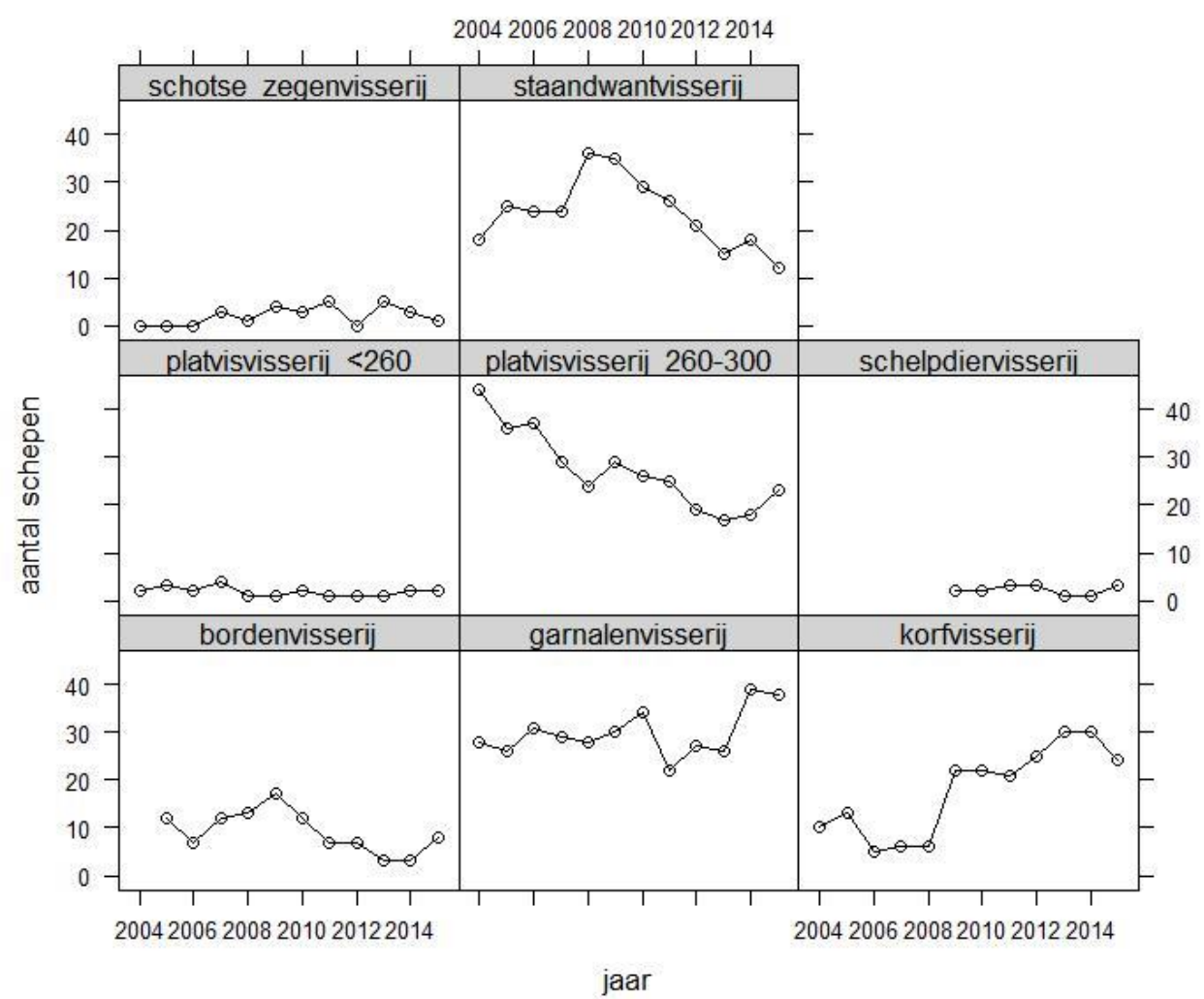

Figuur 0-5 Aantal schepen per jaar per type visserij in de Voordelta.

Tabel 0-4 Aantal schepen per type visserij in de Voordelta tussen 2004-2015, behalve voor schelpdiervisserij (2009-2015) en bordenvisserij (2005-2015).

\begin{tabular}{lr} 
Visserij & Aantal schepen \\
staandwantvisserij & 100 \\
\hline garnalenvisserij & 74 \\
\hline platvisvisserij 260-300 & 68 \\
\hline korfvisserij & 60 \\
\hline bordenvisserij & 41 \\
\hline schotse zegenvisserij & 10 \\
\hline platvisvisserij <260 & 6 \\
\hline schelpdiervisserij & 4 \\
\hline
\end{tabular}

\subsubsection{Aanlandingen uit de Voordelta}

De aanlandingen van de actieve visserij is vele malen hoger dan die van de passieve visserij (Tabel 0-5 en Tabel 0-6); 98.4\% van de totale aanlandingen is afkomstig uit de actieve visserij tussen 2004 en 2015. De meeste aanlandingen ${ }^{6}$ uit de Voordelta betreffen schaal- en schelpdieren; garnalen en Amerikaanse zwaardschede zijn de meest aangelande soorten in de actieve visserij (65.5\% van de totaal aangelande biomassa) en zeekreeft en Noordzeekrab zijn twee van de meest aangelande soorten in de passieve visserij (36.2\% van de totaal aangelande visserij). De belangrijkste vissoort aangeland door de actieve visserij is bot, die $5 \%$ van de totaal aangelande biomassa uitmaakt. Ook schar, tong en schol worden veel aangeland.

\footnotetext{
${ }^{6}$ Dit betreft alle logboek-geregistreerde aanlandingen uit de Voordelta, ook de aanlandingen die niet gekoppeld konden worden aan VMS-gegevens.
} 
Tabel 0-5 Totale aanlandingen (in biomassa) van de actieve visserijen uit de Voordelta tussen 2004-2015. Alleen de soorten die minimaal $1 \%$ van de totale aanlandingen uitmaken zijn getoond. Zie appendix 2 voor het totaal overzicht.

\begin{tabular}{lcc} 
totaal & \% van totaal & $\begin{array}{l}\text { ton } \\
30343\end{array}$ \\
\hline garnaal & 34.5 & 10455 \\
zwaardschede & 29.7 & 9001 \\
bot & 5.0 & 1530 \\
schar & 3.0 & 895 \\
tong & 2.7 & 805 \\
schol & 1.2 & 364
\end{tabular}

Tabel 0-6 Totale aanlandingen (in biomassa) van de passieve visserijen uit ICES-kwadrant $32 F 3$ tussen 2004-2015. Alleen de soorten die minimaal $1 \%$ van de totale aanlandingen uitmaken zijn getoond.

\begin{tabular}{lll} 
totaal & \% van totaal & $\begin{array}{l}\text { ton } \\
496\end{array}$ \\
\hline zeekreeft & 26.5 & 132 \\
tong & 24.4 & 121 \\
Noordzeekrab & 9.7 & 48 \\
harder spec. & 8.8 & 44 \\
zeebaars & 4.3 & 21 \\
kabeljauw & 3.8 & 19 \\
aal & 3.7 & 18 \\
bot & 2.8 & 14 \\
schar & 2.6 & 13 \\
zwaardschede & 2.6 & 13 \\
snoekbaars & 2.6 & 13
\end{tabular}

\subsubsection{Tuigen per schip}

Van de 200 schepen die actief waren in de Voordelta tussen 2004 en 2015, hebben 68 schepen als platviskotters (260-300 PK) gevist (Tabel 0-7). Van deze 68 schepen heeft $72 \%$ (49 schepen) ook met andere tuigen gevist, waarvan de meerderheid (40 schepen) in ieder geval ook op garnalen heeft gevist.

In totaal hebben 79 schepen als garnalenkotters gevist in de Voordelta. Van deze 79 schepen heeft $62 \%$ (49 schepen) ook andere visserijen uitgevoerd, waarbij de meerderheid (40 schepen) in ieder geval ook op platvis heeft gevist (260-300 PK).

Er zijn 93 schepen die noch als garnalenkotter noch als platviskotter hebben gevist, maar enkel met andere tuigen. 
Tabel 0-7 Overzicht van de typen visserij uitgevoerd in 2004-2015 in de Voordelta, met de focus op platviskotters en garnalenkotters.

\begin{tabular}{|c|c|c|c|c|c|}
\hline & Platviskotter & & Geen platviskotter & & \\
\hline \multirow[t]{3}{*}{ Garnalenkotter } & 40 & & 39 & & 79 \\
\hline & Met andere visserij & 24 & Met andere visserij & 9 & \\
\hline & Zonder andere visserij & 16 & Zonder andere visserij & 30 & \\
\hline \multirow[t]{4}{*}{ Geen garnalenkotter } & 28 & & 93 & & 121 \\
\hline & Met andere visserij & 9 & & & \\
\hline & Zonder andere visserij & 19 & & & \\
\hline & 68 & & 122 & & 200 \\
\hline
\end{tabular}

\subsection{De buitenlandse visserij}

De vissersvloten van België, Duitsland, Frankrijk, Denemarken zijn ook actief in de Voordelta. Het gebied waar gevist mag worden verschilt per land: De Belgische vissers mogen overal op het NCP vissen en dus ook binnen de 3-mijlszone. De Duitse en Deense vissers mogen vissen tot aan de 3mijlszone en de Franse vissers tot aan de 6-mijlszone (Figuur 0-1). De Belgen vissen met grote en kleine schepen in de Voordelta, maar de overige landen waarschijnlijk met name met de grotere schepen, gezien de stoomafstand. Deze grotere schepen hebben ook allemaal VMS, terwijl de Belgische vloot dus wellicht ook deels zonder VMS vaart.

De VMS-gegevens van de buitenlandse vloot zijn vanwege privacyoverwegingen niet algemeen beschikbaar in Nederland. Van de Belgische boomkorvloot zijn in de eerste fase van het PMR-project (Prins et al. 2014) opgewerkte gegevens beschikbaar gemaakt: voor de platvisvisserij betrof de bijdrage aan de visserij-inspanning maar enkele procenten maar voor de garnalenvisserij liep dit aandeel in sommige jaren op tot $15 \%$. Over andere landen is enige informatie beschikbaar (ICES 2016). Er is bekend dat bordenvisserij in de Voordelta door Frankrijk beperkt is ( $<100$ visuur in 20092011). Daarnaast wordt er in geringe mate door Duitse en Franse schepen met staandwant gevist (Duitsland: 15-40 visuren in 2011 en 2012, Frankrijk <100 visuren in 2009-2011 (ICES, 2016c). De buitenlandse vloten anders dan België vissen dus zeer fragmentarisch in de Voordelta, en alleen qua staandwantvisserij komt de intensiteit soms in de buurt van die van de Nederlandse vloot (Tabel 0-3). Informatie over onttrekking van vis is helemaal niet beschikbaar voor de buitenlandse vloot. 


\subsection{Recreatieve visserij}

Eens per drie jaar vullen recreatieve vissers op vrijwillige basis maandelijks een enquête in over hun visserij. Op basis van de gegevens van 2010 en 2012 komt het volgende beeld naar voren:

Recreatieve visserij in Zuid Holland en Zeeland omvat voornamelijk hengelvisserij (97\%). De soorten die het meest gevangen worden zijn (in aflopende hoeveelheid): schar, wijting, makreel, kabeljauw, bot, schol en zeebaars. De recreatieve visserij in de Voordelta is zeer klein vergeleken met de visserij in de naburige gebieden (kust van Zuid-Holland en Westerschelde, Figuur 0-6).

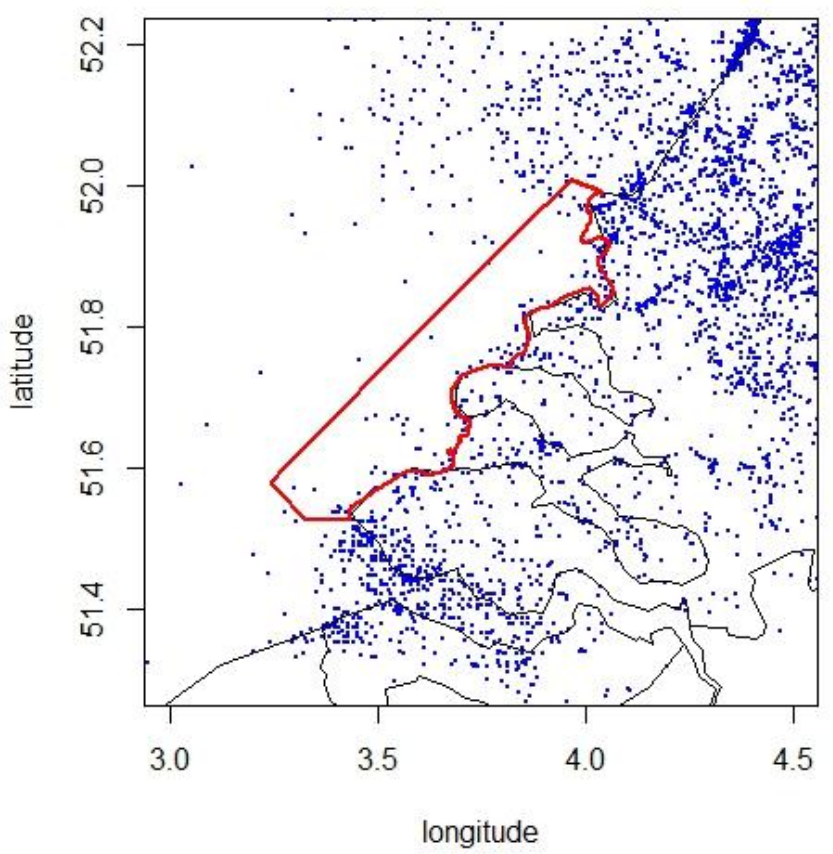

Figuur 0-6 Ruimtelijke verdeling van recreatieve visserij in zout water, zoals gemeld door de recreatieve vissers in 2010 en 2012. Eén blauwe stip is één visreis zoals aangegeven door een visser in Google Maps. In rood de Voordelta. 


\section{Trends in inspanning}

\subsection{Platviskotters in de Voordelta}

De platviskotters (260-300 PK) zijn de meest dominante platvisvisserij in de Voordelta (98.7\%). Aangezien ook de maatregel van het BBG alleen geldt voor deze platvisvisserij, wordt daarom in de rest van het rapport alleen de visserij van deze platviskotters behandeld.

\subsubsection{Jaarlijkse inspanning}

Tussen 2004 en 2015 hebben 68 Nederlandse platviskotters gevist in de Voordelta. Het aantal schepen dat per jaar vist in de Voordelta is gestaag afgenomen, van 44 in 2004 naar 23 in 2015 (Figuur 0-7).

Ook de totale inspanning van deze schepen in de Voordelta is sterk gedaald door de jaren heen. In 2004 zijn 9.215 visuren doorgebracht in de Voordelta, terwijl sinds 2009 minder dan 1.800 uren per jaar is gevist. De inspanning lijkt sinds 2010 redelijk stabiel. De inspanning is elk jaar verdeeld over een grote groep schepen en komt niet hoofdzakelijk voor rekening van een paar zeer actieve schepen (ongepubliceerde gegevens).

Ook de gemiddelde inspanning per actief schip neemt af, van gemiddeld 209 visuren in 2004 naar 74 visuren in 2015. Sinds 2009 lijkt ook de gemiddelde inspanning redelijk stabiel.

Deze drie trends duiden op een robuuste afname van de totale inspanning in de Voordelta, wat wordt veroorzaakt door zowel een afname in het aantal vissende schepen en een afname in de inspanning per vissend schip. In hoofdstuk 3.1.6 en 3.1.7 worden deze trends vergeleken met de trends Noordzeebreed en in de Noordzeekustzone.
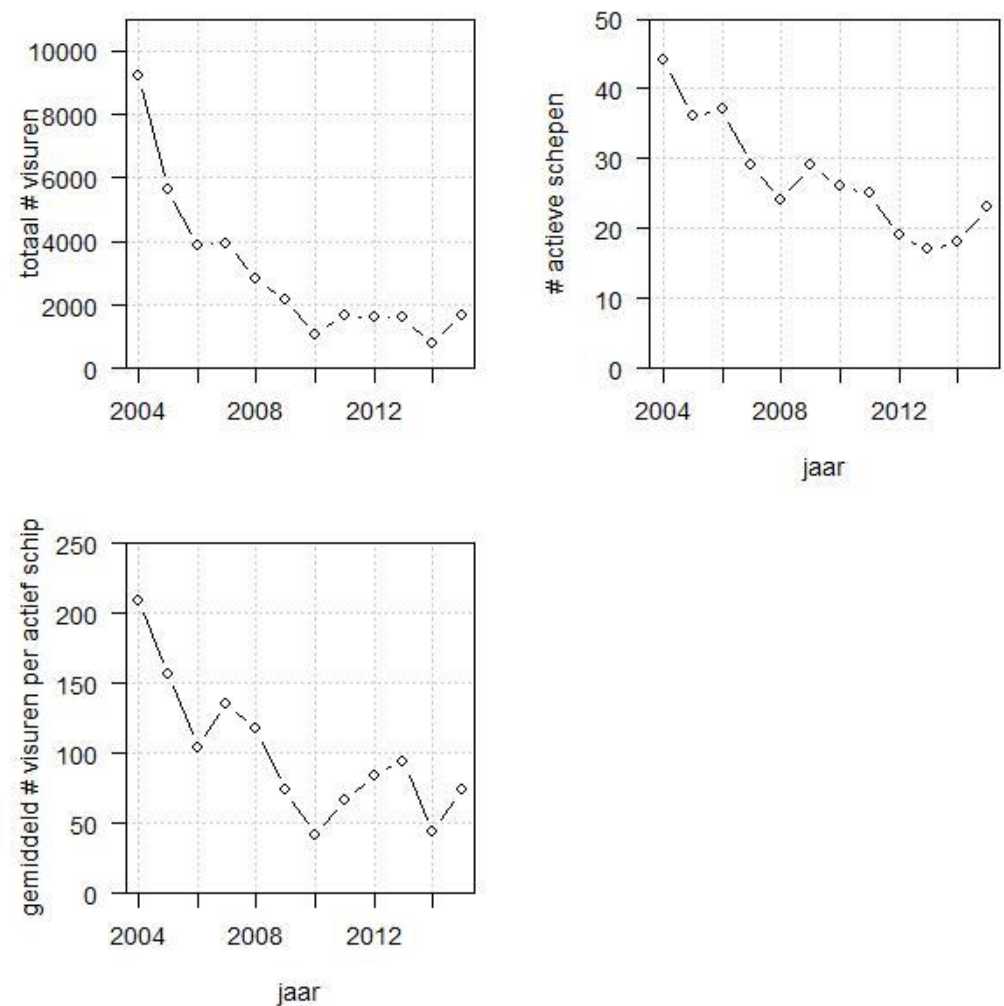

Figuur 0-7 De visserij van de platviskotters in de Voordelta tussen 2004-2015. Totaal \# visuren: aantal visuren dat in totaal gevist is. \# actieve schepen: aantal schepen dat gevist heeft. Gemiddeld \# visuren per actief schip: het gemiddelde aantal visuren van één actief schip. Zie Appendix 2 voor onderliggende gegevens. 


\subsubsection{Ruimtelijke trends}

Alhoewel de inspanning van de platviskotters in de Voordelta wel is afgenomen, is de ruimtelijke verdeling binnen de Voordelta niet wezenlijk veranderd door de jaren heen (Prins et al. 2014). In Figuur 0-8 zijn ook dezelfde patronen te zien: er is een absolute afname, maar geen sterk verschil in ruimtelijke verdeling. De gebieden met de grootste inspanning lagen in 2004-2007 ten noorden van het BBG en in de zuidwesthoek van de Voordelta. Dit patroon is ook na 2008 gebleven.

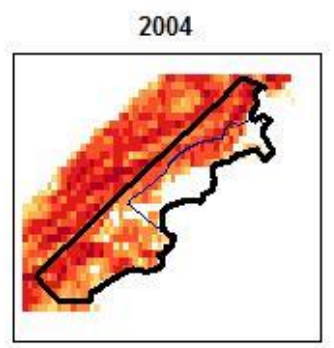

2005
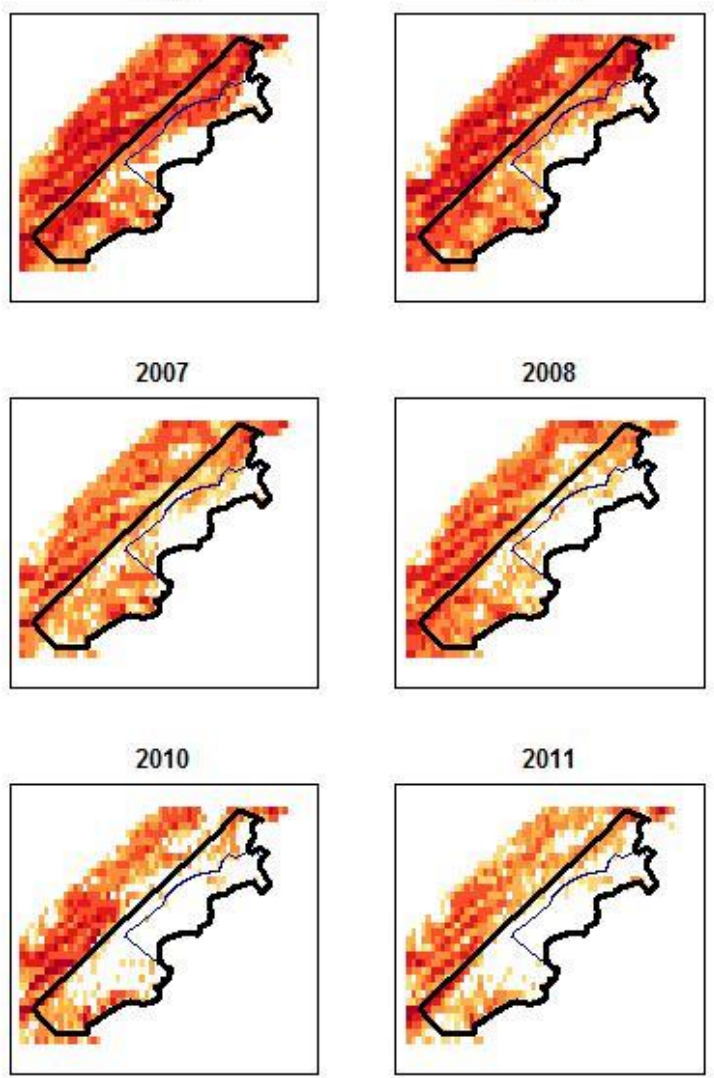

2013

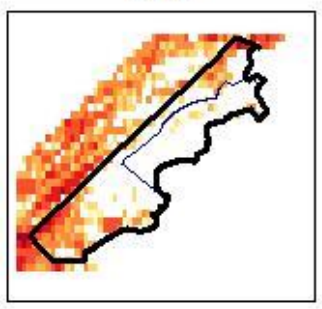

2008

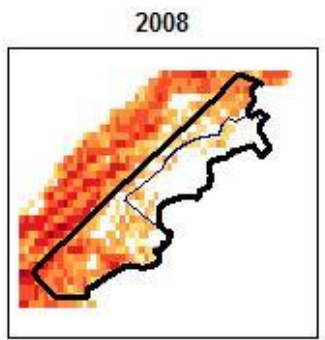

2011

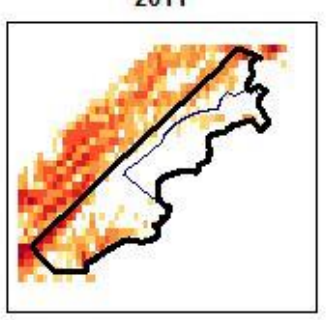

2014

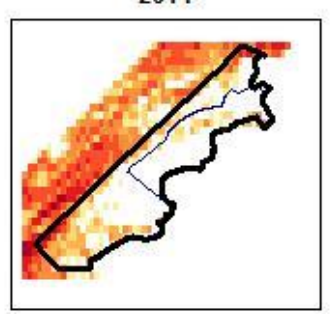

2006

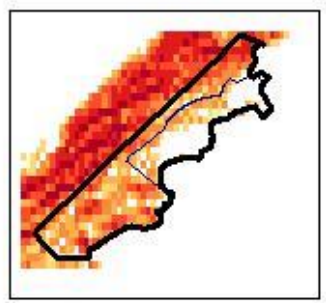

2009

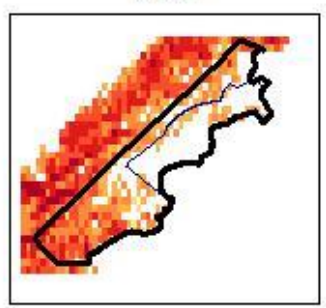

2012

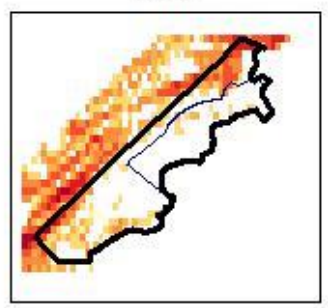

2015

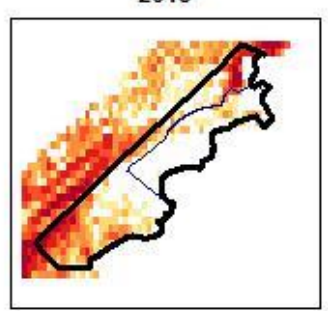

Visuren

ㅁ 0

$\square 0<=18$

$\square \quad 18<=45$

$\square \quad 45<=90$

ㅁ $90<=180$

$\square \quad 180<=450$

$\square \quad 450<=900$

- $900<=1800$

- $1800<=4500$

Figuur 0-8. Ruimtelijke verdeling van de jaarlijkse inspanning (in visuren) per $1 \mathrm{~km}$ gridcel van de platviskotters in de Voordelta (zwart omlijnd) en het BBG (blauw omlijnd) tussen 2004 en 2015.

\subsubsection{Seizoenstrends}

Er is weinig verschil tussen jaren in de seizoensdynamiek: de totale inspanning nam wel af door de jaren heen, maar de verdeling van deze inspanning over een jaar is grofweg hetzelfde gebleven (Appendix 2). De inspanning is het laagst in de winter (week $51 \mathrm{t} / \mathrm{m}$ week 10) en bereikt na de winter een piek in week 15 (Figuur 0-9). Daarna neemt de inspanning langzaam af. Gemiddeld genomen wordt er wel het hele jaar door gevist, zonder sterke concentratie in een klein aantal weken; het gemiddelde percentage inspanning per week is nergens groter dan $4.1 \%$ van het jaartotaal. 


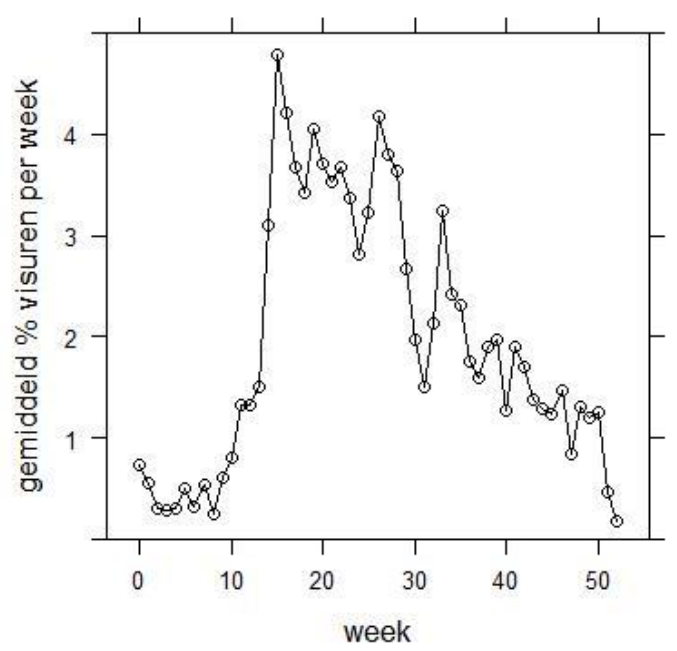

Figuur 0-9 Gemiddelde percentage visuren per week voor de platvisvloot in de Voordelta tussen 2004-2015. Het percentage visuren is eerst binnen een jaar berekend per week, en daarna gemiddeld over de 12 jaren. Zie Appendix 2 voor de trend per jaar

\subsubsection{Havens}

De platviskotters die tussen 2004 en 2015 in de Voordelta hebben gevist, maakten voor deze reizen gebruik van verschillenden havens, waarvan Stellendam (37.4\%), Colijnsplaat $(25.7 \%)$ en Vlissingen $(20.6 \%)$ de meest bezochte havens zijn (Fout! Verwijzingsbron niet gevonden.). Stellendam en Colijnsplaat zijn steeds minder gebruikt, terwijl het gebruik van Vlissingen stabiel is gebleven (Figuur 0-10).

Van de schepen voer $22 \%$ exclusief op één haven (Figuur 0-11). De haven die het meest gebruikt is (de ' thuishaven') voor visreizen die de Voordelta aandoen, werd gemiddeld in $72 \%$ van de reizen gebruikt. Een schip benutte voor zijn Voordelta-reizen gemiddeld 3.6 havens in 12 jaar.

Tabel 0-8 Reizen van of naar een haven, van de platviskotters vissend tussen 2004-2015 in de Voordelta.

\begin{tabular}{lrr} 
Haven & Aantal reizen & Percentage \\
Stellendam & 2584 & 37.4 \\
\hline Colijnsplaat & 1775 & 25.7 \\
\hline Vlissingen & 1421 & 20.6 \\
\hline IJmuiden & 296 & 4.3 \\
\hline onbekend & 291 & 4.2 \\
\hline Scheveningen & 216 & 3.1 \\
\hline Breskens & 153 & 2.2 \\
\hline Den Helder & 93 & 1.3 \\
\hline Yerseke & 27 & 0.4 \\
\hline Texel & 24 & 0.3 \\
\hline Oostende & 16 & 0.2 \\
\hline Harlingen & 2 & $<0.1$ \\
\hline Roompotsluis & 2 & $<0.1$ \\
\hline
\end{tabular}




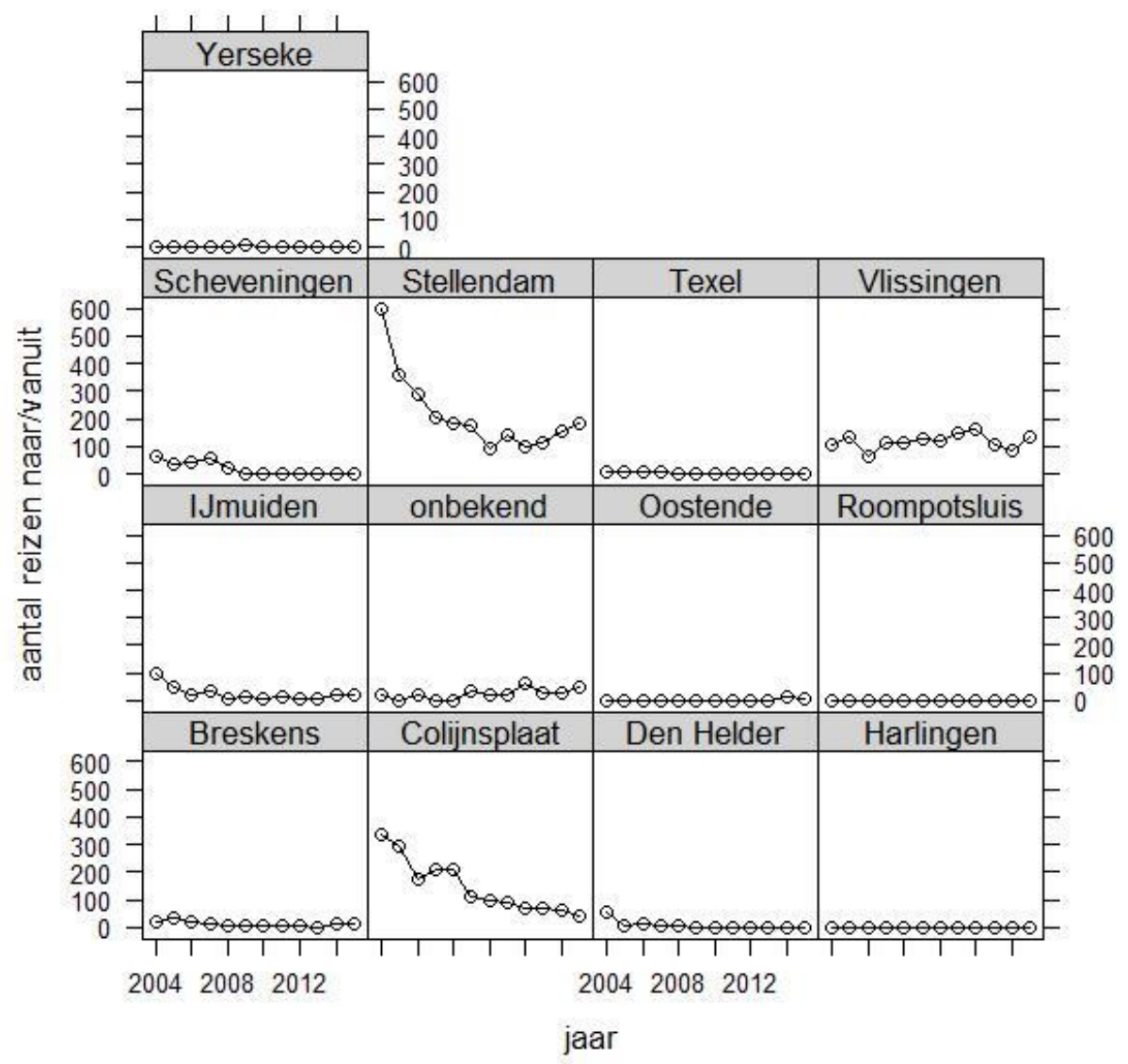

Figuur 0-10 Reizen van of naar een haven per jaar, van de platviskotters vissend in de Voordelta.

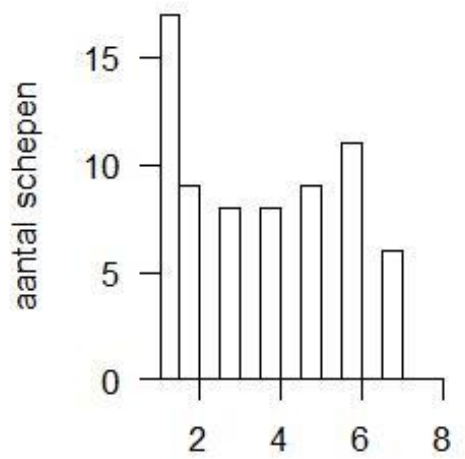

aantal benutte havens

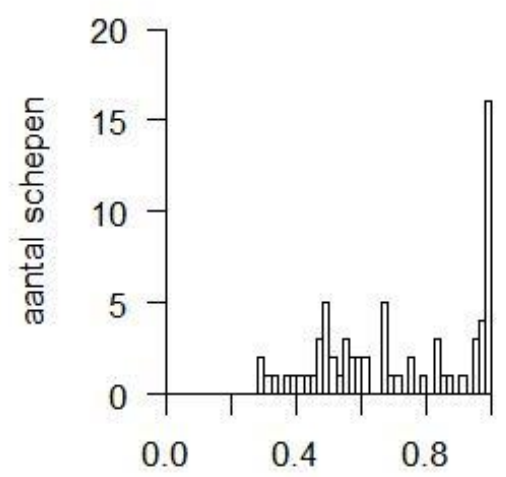

fractie reizen voornaamste haven

Figuur 0-11 Havengebruik per schip, van de platviskotters vissend in de Voordelta tussen 2004-2015. Links: Het aantal havens dat een schip benut afgezet tegen het aantal schepen. Rechts: De fractie van de visreizen die een schip naar/van de voornaamste haven ('de thuishaven') maakt, afgezet tegen het aantal schepen. 


\subsubsection{Vernieuwende tuigen}

De visserij met puls is sinds 2008 toegestaan?. Sinds 2011 komt deze visserij voor in de Voordelta, waarbij de inspanning redelijk stabiel is gebleven (Figuur 0-12), maar het aantal schepen vissend met puls sterk is toegenomen.

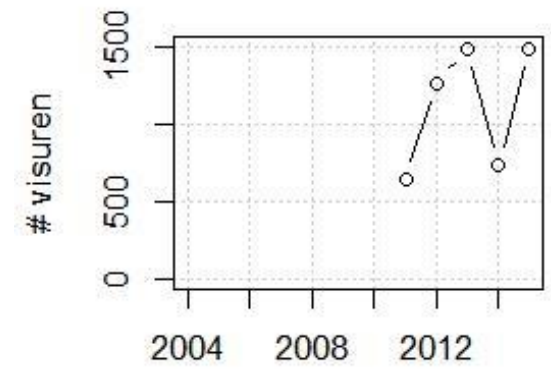

jaar

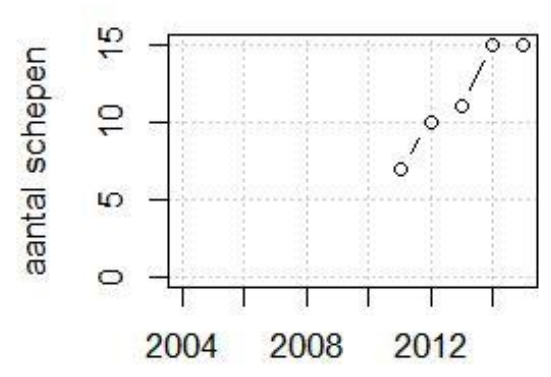

jaar

Figuur 0-12 De visserij van de platviskotters met puls, in de Voordelta tussen 2004-2015. \# visuren: aantal visuren dat gevist is met puls. \# schepen: aantal schepen dat gevist heeft met puls.

\subsubsection{Noordzeebrede visserij}

De 68 platviskotters die in de Voordelta vissen, maken allemaal gebruik van een groter gebied dan alleen de Voordelta, maar beperken zich tot de Noordzee. De totale inspanning in de gehele Noordzee van deze schepen is -zoals in de Voordelta- gedaald door de jaren, van 94 naar 47 duizend visuren tussen 2004 en 2015 (Figuur 0-13) ${ }^{8}$. De afname in de Voordelta is echter nog sterker: het aandeel inspanning in de Voordelta ten opzichte van de hele Noordzee neemt consistent af door de jaren (Figuur 0-14); van $10 \%$ van de jaarlijkse inspanning naar $4 \%$.

Het aantal platviskotters dat actief is in de Noordzee neemt ook af door de jaren, van 44 naar 25 (Figuur 0-13). Van deze actieve schepen is een stabiel aantal schepen ook actief in de Voordelta (Figuur 0-14).

De gemiddelde inspanning van de actieve schepen Noordzeebreed blijft redelijk stabiel (Figuur 0-14). Dit is anders dan in de Voordelta (Figuur 0-7). De afname in inspanning van de kleine platvisvloot Noordzeebreed lijkt dus veroorzaakt door met name een afname van het aantal actieve schepen, en niet door een verminderde inspanning per actief schip. Dit is anders dan in de Voordelta, waar zowel het aantal actieve schepen als de inspanning per actief schip sterk afneemt.

\footnotetext{
${ }^{7}$ Ook de sumwing is een vernieuwend tuig, maar dit tuig heeft geen invloed op de vangsten, alleen op de benodigde brandstof. Daarom is deze vernieuwing hier buiten beschouwing gelaten.

${ }^{8}$ Er zijn ook platviskotters die tussen 2004-2015 helemaal niet in de Voordelta hebben gevist. Dit zijn 33 schepen. Deze hebben echter veel minder visuren dan de 68 schepen die (ook) in de Voordelta hebben gevist. De trend in inspanning door de jaren heen verschilt ook nauwelijks met de 68 schepen die in de Voordelta vissen. Zie appendix 2; ondersteunende figuur bij figuur 3-7.
} 

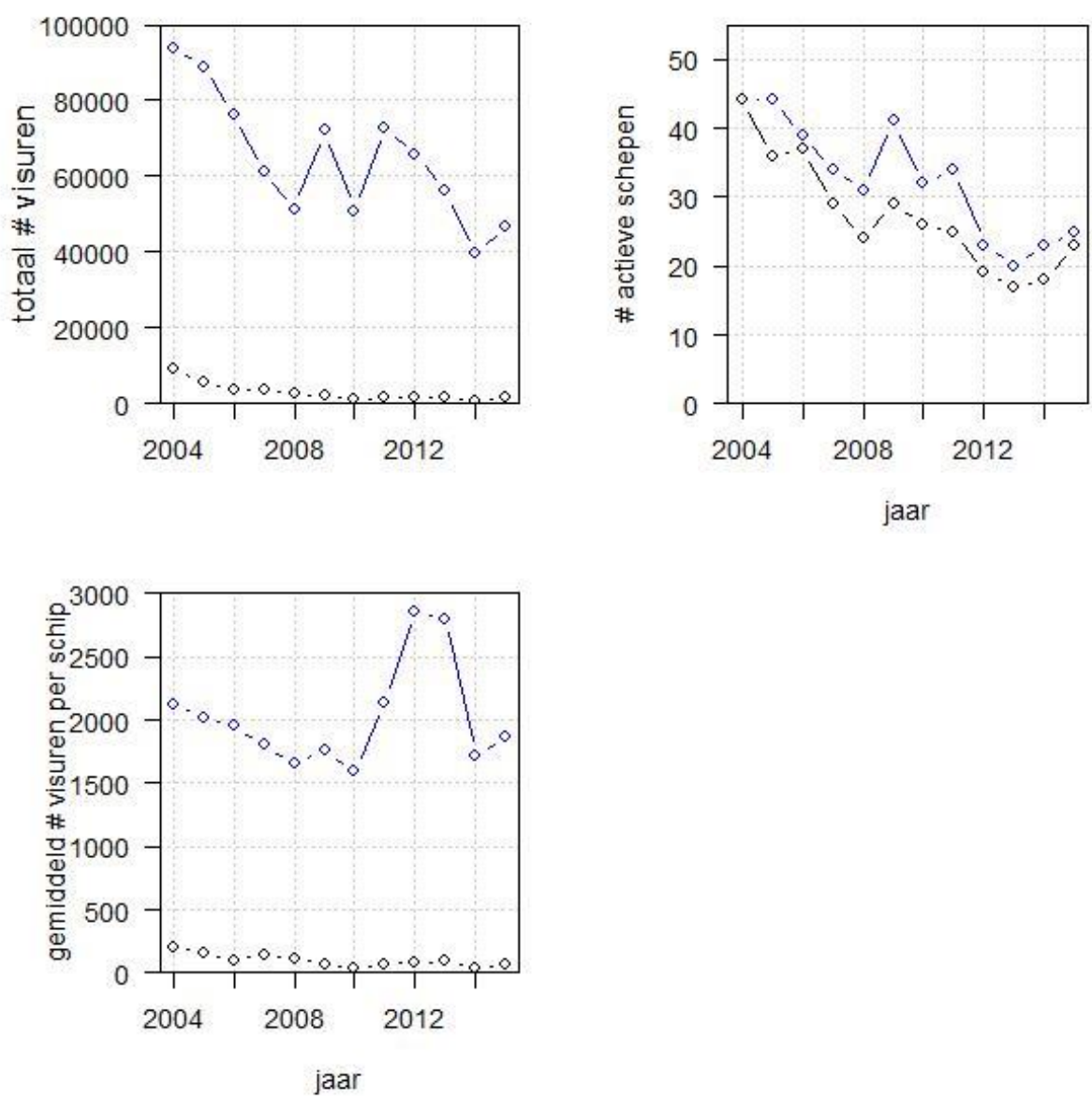

Figuur 0-13. De visserij van de platviskotters die tussen 2004-2015 in de Voordelta actief zijn geweest: in de gehele Noordzee (blauw) en in de Voordelta (zwart). Totaal \# visuren: aantal visuren dat in totaal gevist is. \# actieve schepen: aantal schepen dat gevist heeft. Gemiddeld \# visuren per schip: het gemiddelde aantal visuren van één actief schip. Zie Appendix 2 voor de onderliggende gegevens. 
De meeste actieve platviskotters vissen weinig in de Voordelta (Figuur 0-14). Een actieve platviskotter besteedt tussen 2004 en 2015 gemiddeld 7\% van zijn jaarlijkse inspanning in de Voordelta. Vanaf 2009 is een veel lager gemiddelde fractie tijd die ze in de Voordelta doorbrengen te zien. Ook tussen 2004 en de rest van de tijdreeks lijkt een verschil te zijn, met veel minder tijd in de Voordelta in 2005-2008. Bij deze overgang van 2004 naar 2005 is nog een opmerkelijk verschil te zien: in 2004 brengt 100\% van de schepen enige tijd door in de Voordelta, terwijl vanaf 2005 een deel van de schepen hier geen tijd meer doorbrengt (ongepubl. gegevens). Deze fractie blijft vrij stabiel voor 2005-2015.

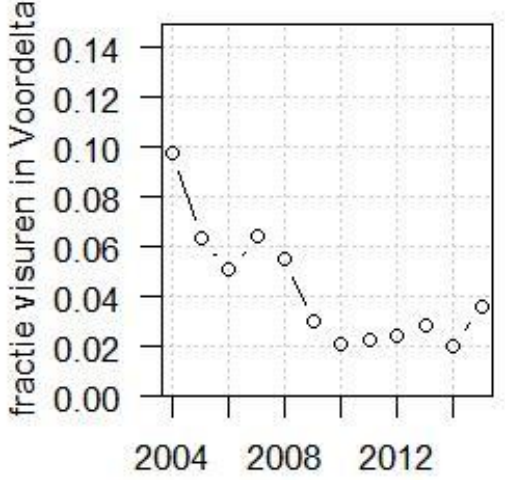

jaar

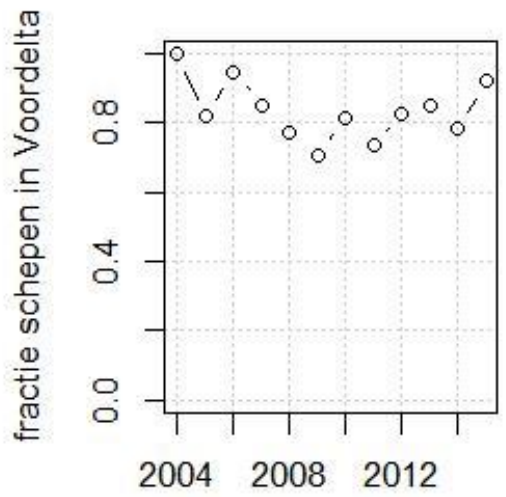

jaar

Figuur 0-14 Het aandeel visserij in de Voordelta van de 68 platviskotters die tussen 2004-2015 in de Voordelta actief zijn geweest, van de Noordzeebrede visserij van deze platviskotters. Fractie visuren in Voordelta: fractie van het aantal visuren in de Voordelta is doorgebracht. Fractie schepen in Voordelta: fractie van het aantal schepen dat (ook) in de Voordelta heeft gevist.

Als gekeken wordt naar het gedrag van individuele schepen (Figuur 0-15) is te zien dat voor 2008 er wel individuele schepen zijn die veel tijd in de Voordelta doorbrachten, daarna veel minder. De Voordelta wordt niet in elke visreis aangedaan; in bijna 71\% van de visreizen tussen 2004 en 2015 wordt de Voordelta niet bezocht, in ruim $28 \%$ van de visreizen wordt de Voordelta wel bezocht, terwijl minder dan $0.01 \%$ van de visreizen alleen in de Voordelta wordt doorgebracht.

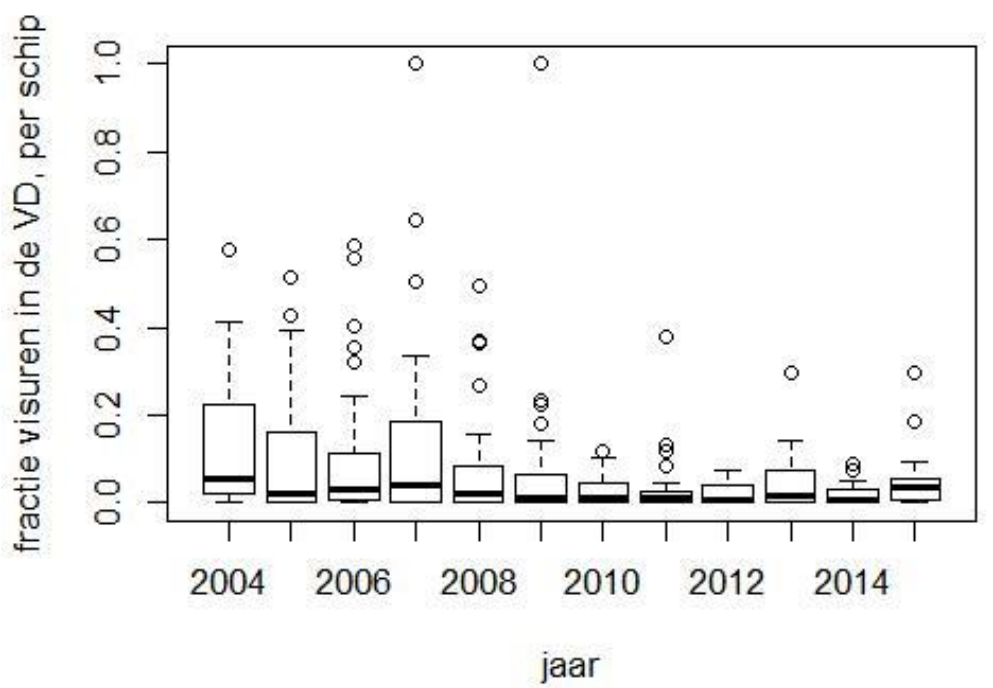

Figuur 0-15 Boxplot van de fractie visserij inspanning in de Voordelta van de 68 platviskotters die tussen 2004-2015 in de Voordelta actief zijn geweest, van de Noordzeebrede inspanning van deze platviskotters. 


\subsubsection{Noordzeekustvisserij}

Om te achterhalen of er patronen zijn die specifiek zijn voor de kustvisserij, zijn dezelfde analyses als hierboven uitgevoerd voor de visserij binnen de 6-mijl-zone en binnen de 12-mijl-zone van het Europese vasteland (dus zonder het Verenigd Koninkrijk). De patronen binnen de 6- en 12-mijl-zone waren gelijk aan die van de Noordzeevisserij waarbij het aantal actieve schepen jaarlijks vrijwel hetzelfde is als in de Noordzee en het aantal visuren dezelfde trend door de tijd vertoont (Figuur 0-16). De fractie visserij in de Voordelta ten opzichte van de visserij in 12-mijl-zone en in de 6-mijlzone is allebei met een factor 2.5 afgenomen sinds 2004, zoals ook hierboven voor de Noordzee is gevonden (Figuur 0-17). Ook in de 6- en 12-mijl-zone is de trend anders dan die in de Voordelta.

Er lijkt dus niet een kustspecifieke afname in platvisvisserij van deze kotters te zijn: er is een Noordzeebrede afname, en daar bovenop lijkt er een Voordelta-specifieke afname te zijn.
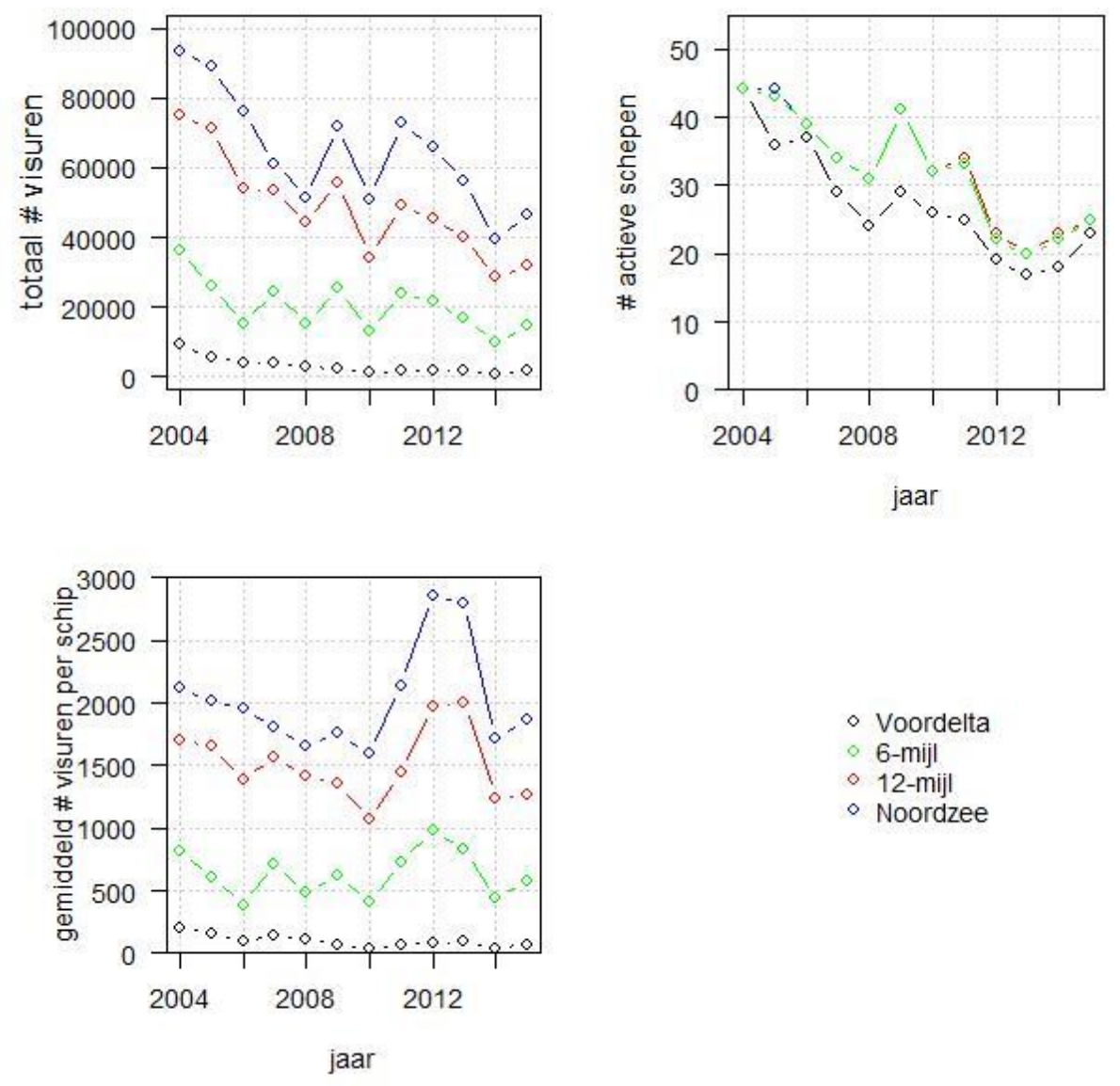

Figuur 0-16. De visserij van de 68 platviskotters die tussen 2004-2015 in de Voordelta actief zijn geweest: in de gehele Noordzee (blauw), binnen de 12-mijl-zone (rood), binnen de 6-mijl-zone (groen) en in de Voordelta (zwart). Totaal \# visuren: aantal visuren dat in totaal gevist is. \# actieve schepen: aantal schepen dat gevist heeft (blauw, rood en groen overlappen vrijwel volledig). Gemiddeld \# visuren per schip: het gemiddelde aantal visuren van één actief schip. 


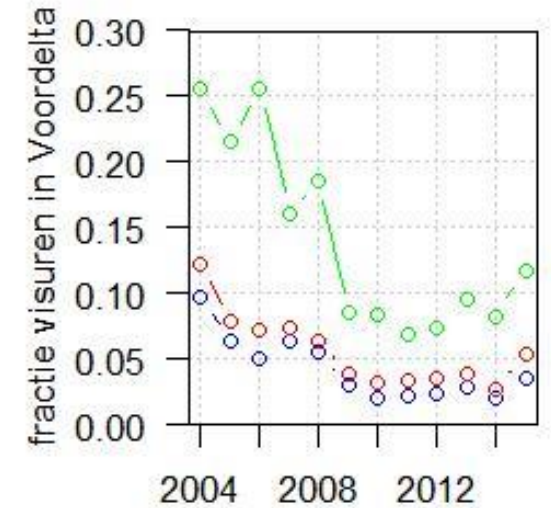

jaar

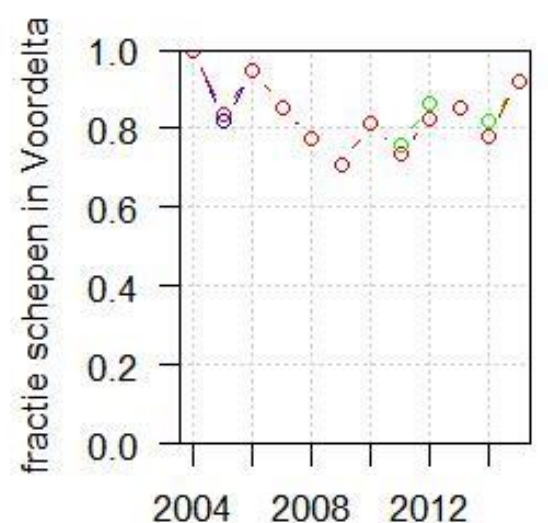

jaar

Figuur 0-17. Het aandeel visserij in de Voordelta van de 68 platviskotters die tussen 2004-2015 in de Voordelta actief zijn geweest, van hun gehele visserij Noordzeebreed (blauw), van hun visserij binnen de 12mijl-zone (rood) en binnen de 6-mijl-zone (groen). Fractie visuren in Voordelta: fractie van het aantal visuren dat in de Voordelta is doorgebracht. Fractie schepen in Voordelta: fractie van het aantal schepen dat (ook) in de Voordelta heeft gevist (blauw, rood en groen overlappen vrijwel volledig).

\subsection{Garnalenkotters in de Voordelta}

\subsubsection{Jaarlijkse inspanning}

Tussen 2004 en 2015 hebben 79 Nederlandse garnalenkotters gevist in de Voordelta ${ }^{9}$. Het aantal schepen dat per jaar vist in de Voordelta is toegenomen tussen 2004 en 2015, van 30 in 2004 naar 40 in 2015 (Figuur 0-18). Het aantal schepen nam toe over de gehele periode maar vertoonde wel sterke fluctuaties; het aantal actieve schepen tussen 2011 en 2013 was juist lager dan andere jaren.

De totale inspanning van deze schepen in de Voordelta is sterk gestegen sinds 2004. In 2004 zijn 10.235 visuren doorgebracht in de Voordelta, terwijl in 201528.730 uren per jaar gevist wordt op garnaal, bijna een verdrievoudiging in 11 jaar. Ook deze totale inspanning vertoont sterke fluctuaties tussen jaren, maar nam sinds 2009 elk jaar toe. De inspanning is elk jaar verdeeld over een grote groep schepen. Ook de gemiddelde inspanning per schip is toegenomen, van gemiddeld 341 visuren in 2004 naar 718 visuren in 2015. Ook hierbij is sterke jaar-op-jaar fluctuatie te zien (Figuur 0-18).

Deze drie trends duiden op een toename van de totale inspanning van garnalenkotters in de Voordelta, veroorzaakt door zowel een toenemend aantal vissende schepen en een toenemende inspanning per vissend schip. De jaar-op-jaar fluctuaties in de garnalenvisserij zijn wel sterker dan in de platvisvisserij.

\footnotetext{
${ }^{9}$ Voor de berekening van de inspanning van de garnalenvloot is met een andere dataset gewerkt dan in hoofdstuk 2 beschreven. Voor 2004 en 2005 was het in het verleden door een gebrek aan logboekgegevens over de garnalenvloot niet mogelijk om de garnalenvisserij te definiëren, een essentiële stap om de VMS-gegevens te analyseren. In 2016 is het gelukt om via andere databronnen de garnalenvisserij in 2004 en 2005 te definiëren en daardoor de beschikbare VMS-gegevens op te werken.
} 

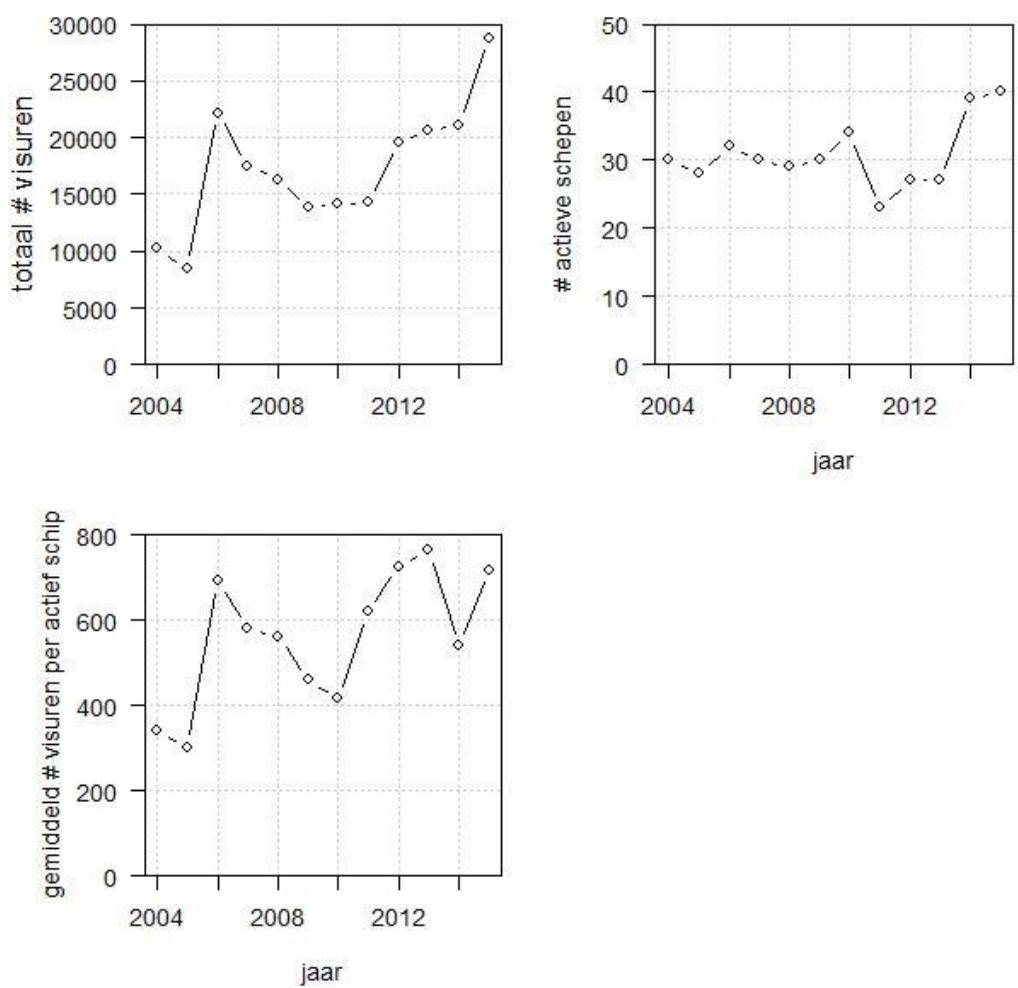

Figuur 0-18 De visserij van de garnalenkotters in de Voordelta tussen 2004-2015. Totaal \# visuren: aantal visuren dat in totaal gevist is. \# actieve schepen: aantal schepen dat gevist heeft. Gemiddeld \# visuren van actieve schepen: het gemiddelde aantal visuren van één actief schip. Zie Appendix 2 voor onderliggende gegevens.

\subsubsection{Noordzeebrede visserij}

De 79 garnalenkotters die in de Voordelta vissen maken allemaal gebruik van een groter gebied dan alleen de Voordelta. Dat gebied is wel beperkt tot de Noordzee. De totale inspanning in de gehele Noordzee van deze schepen is -zoals in de Voordelta- gestegen door de jaren, van grofweg 80 duizend in 2004 naar 110 duizend visuren in 2015 (Figuur 0-19). Het aandeel van de inspanning in de Voordelta fluctueert maar vertoont geen trend vanaf 2006 (Figuur 0-20). Echter, in de twee jaar ervoor lijkt het aandeel in de Voordelta wel iets lager te liggen: de 13\% bijdrage van de Voordelta in 2004 en 2005 is iets lager dan alle jaren erna. Het is echter lastig vast te stellen of dit een consistente trend is; hiervoor is een langere tijdserie nodig.

Het aantal garnalenkotters dat per jaar actief is in de Noordzee is gestegen van 45 naar 52 . Van deze actieve schepen is een stabiel aantal schepen (ook) actief in de Voordelta (Figuur 0-20).

De gemiddelde inspanning van de actieve schepen Noordzeebreed neemt ook toe (Figuur 0-19), zoals ook in de Voordelta. De toename in inspanning van de garnalenvloot Noordzeebreed lijkt dus veroorzaakt door een toename van het aantal actieve schepen, en van de inspanning per actief schip. Wel is wellicht het aandeel van de inspanning in de Voordelta een klein beetje hoger na 2006 dan ervoor, maar dit is niet met zekerheid te zeggen. 

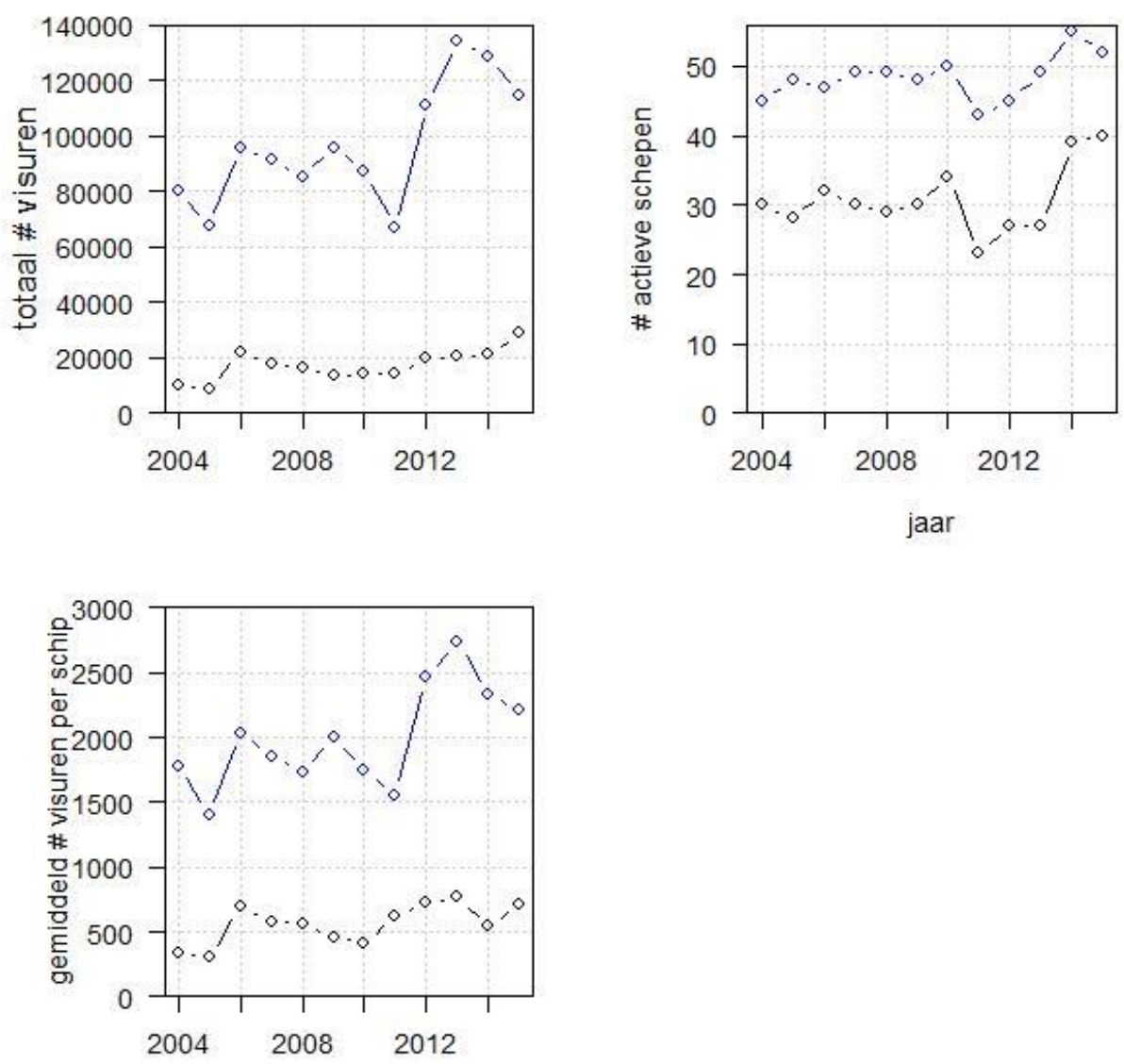

jaar

Figuur 0-19. De visserij van de garnalenkotters die tussen 2004-2015 in de Voordelta actief zijn geweest: in de gehele Noordzee (blauw) en in de Voordelta (zwart). Totaal \# visuren: aantal visuren dat in totaal gevist is. \# actieve schepen: aantal schepen dat gevist heeft. Gemiddeld \# visuren per schip: het gemiddelde aantal visuren van één actief schip. Zie Appendix 2 voor onderliggende gegevens.

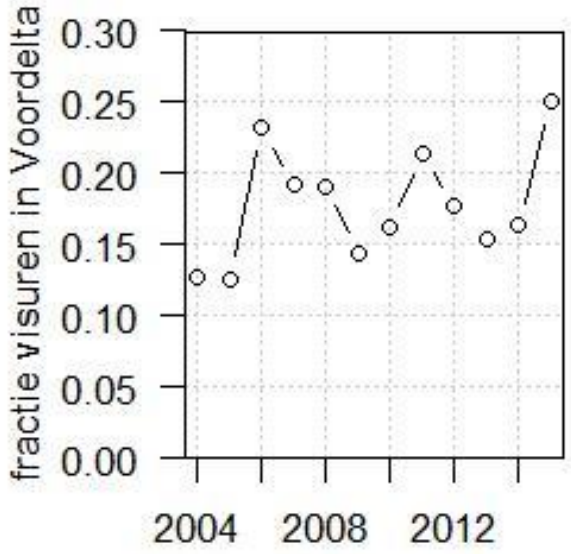

jaar

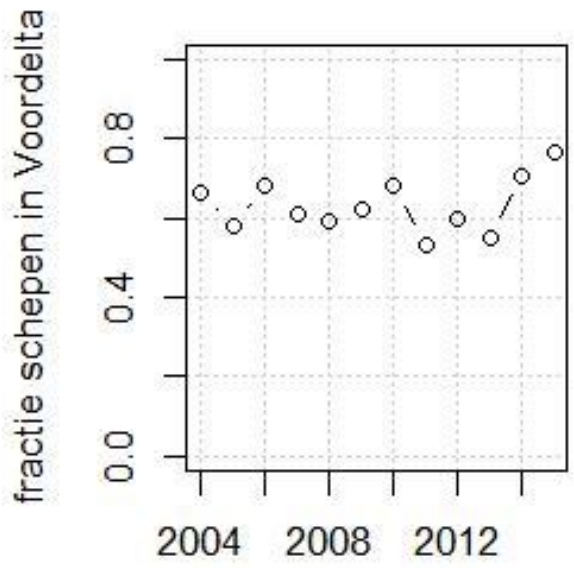

jaar

Figuur 0-20. Het aandeel visserij in de Voordelta van de 74 garnalenkotters die tussen 2004-2015 in de Voordelta actief zijn geweest, van de Noordzeebrede visserij van deze kotters. Fractie visuren in Voordelta: fractie van het aantal visuren in de Voordelta is doorgebracht. Fractie schepen in Voordelta: fractie van het aantal schepen dat (ook) in de Voordelta heeft gevist. 
De meeste actieve garnalenkotters vissen veel in de Voordelta, in vergelijking met een platviskotter (hoofdstuk 3.1.6); een actieve garnalenkotter besteed gemiddeld 24\% van zijn jaarlijkse inspanning in de Voordelta, terwijl een actieve platviskotter maar $7 \%$ hier doorbrengt. Ook brengen steeds meer garnalenkotters veel tijd door in de Voordelta (Figuur 0-21). De fractie van hun tijd die ze in de Voordelta doorbrengen varieert van jaar tot jaar, maar ligt gemiddeld rond de $10 \%$.

De Voordelta wordt niet in elke visreis aangedaan; in $62 \%$ van de visreizen wordt de Voordelta niet bezocht. In $37 \%$ van de visreizen wordt de Voordelta (ook) bezocht, waarbij $23 \%$ van de visreizen alleen in de Voordelta wordt doorgebracht. Visreizen door de garnalenvisserij lijken dus meer ruimtelijk geconcentreerd te zijn dan visreizen door de platvisvisserij (hoofdstuk 3.1.6); binnen een visreis wordt binnen een kleiner gebied gevist.

Deze kleinere schaal van vissen per visreis zou wellicht het meer grillige verloop van de jaartrends (dan die van de platvisvisserij) kunnen verklaren. Daarnaast zou de kortere levenscyclus van garnaal een rol kunnen spelen; waar een schip gaat vissen is hierbij waarschijnlijk meer afhankelijk van waar dat jaar toevallig de grootste dichtheden zijn.

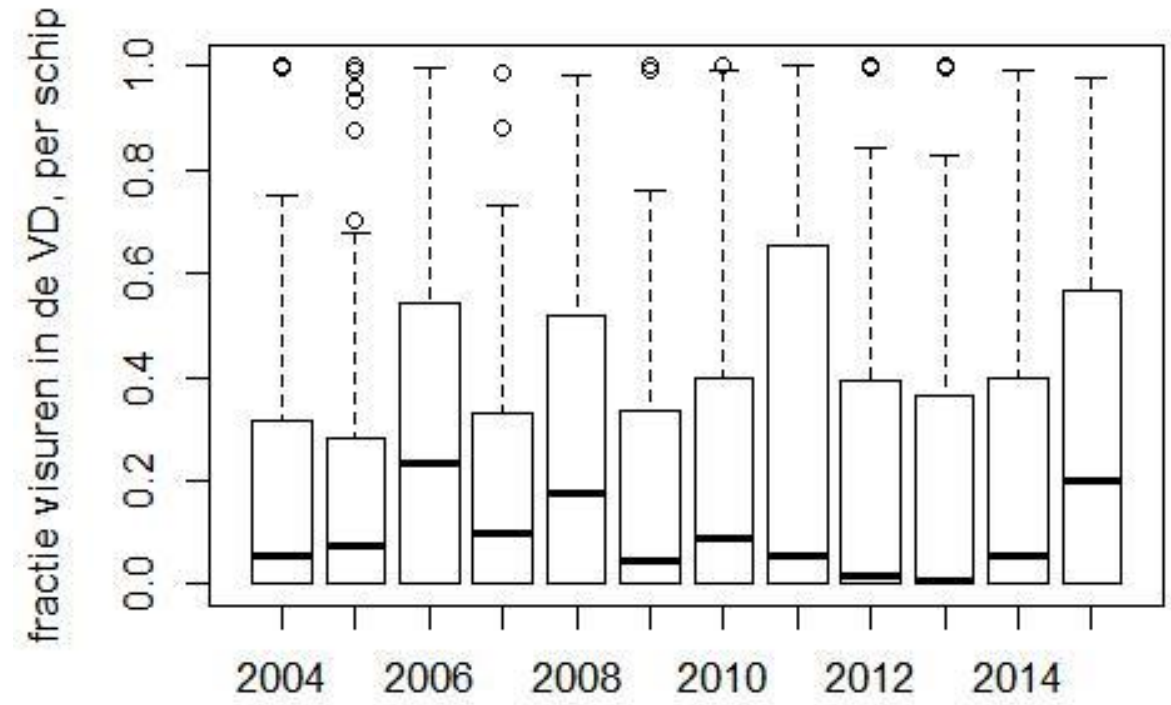

jaar

Figuur 0-21 Boxplot van de fractie visserij in de Voordelta van de 79 garnalenkotters die tussen 2004-2015 in de Voordelta actief zijn geweest, van de Noordzeebrede visserij van deze kotters. 


\subsubsection{Ruimtelijke verspreiding}

De garnalenvisserij vind plaats over de hele Voordelta en ook in het buitengebied. Het heeft een hoge intensiteit in het BBG. Door de jaren heen heeft de visserij zich ontwikkeld en steeds meer de nadruk gelegd op het BBG. Daarbuiten vindt vooral garnalenvisserij net onder de Voordelta plaats.

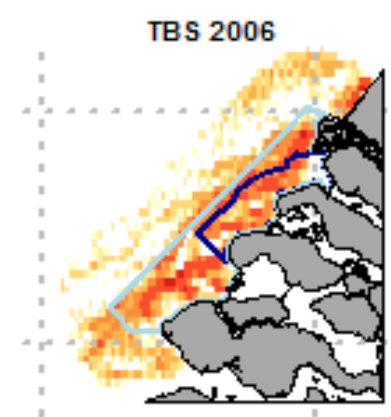

TBS 2009

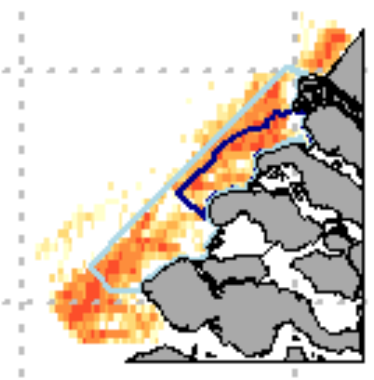

TBS 2012

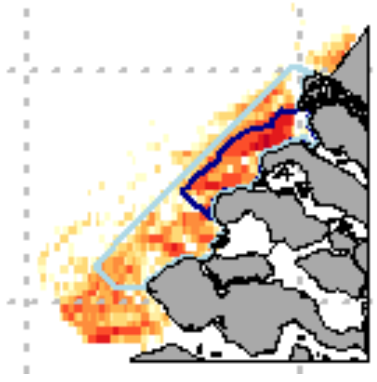

TBS 2007

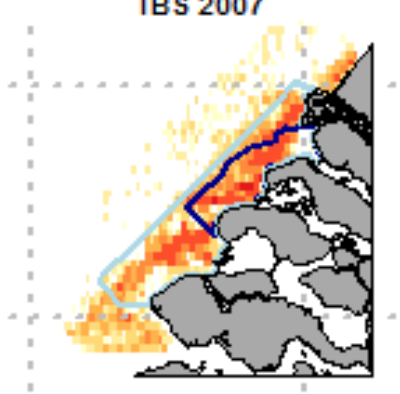

TBS 2010

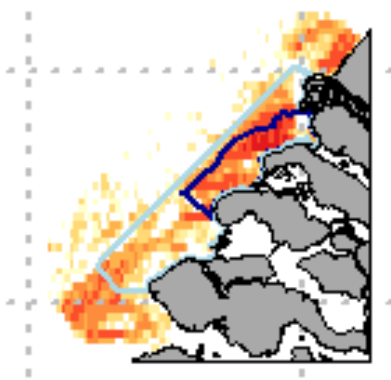

TBS 2013

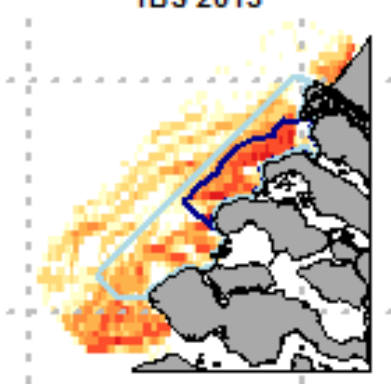

TBS 2008

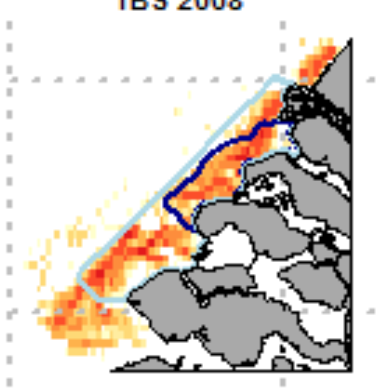

TBS 2011

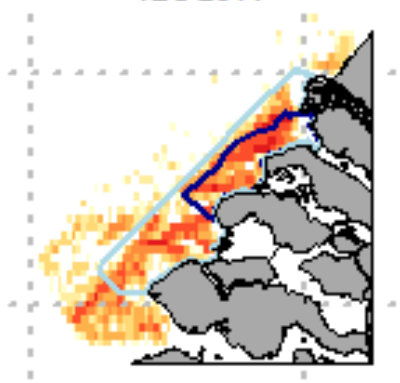

TBS 2014

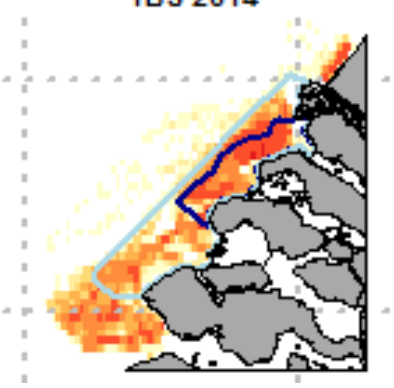

Figuur 0-22 Ruimtelijke verdeling van de jaarlijkse inspanning (in visuren) per $1 \mathrm{~km}$ gridcel van de garnalenkotters in de Voordelta (lichtblauw omlijnd) en het BBG (blauw omlijnd) tussen 2006 en 2014.

\subsection{Combinatie garnaal- en platvisvisserij}

Van de 68 schepen die tussen 2004 en 2015 met platvistuig hebben gevist (hoofdstuk 3.1) vist het merendeel ook met andere tuigen (58\%, hoofdstuk 2.1.4). Het grootste deel van de inspanning in de Voordelta van deze 68 schepen wordt besteed aan de garnalenvisserij (Figuur 0-23). Dit aandeel neemt ook toe door de jaren heen, terwijl het aandeel platvisvisserij afneemt. Met andere tuigen wordt vrijwel niet gevist, en dit aandeel neemt ook af door de jaren heen. 


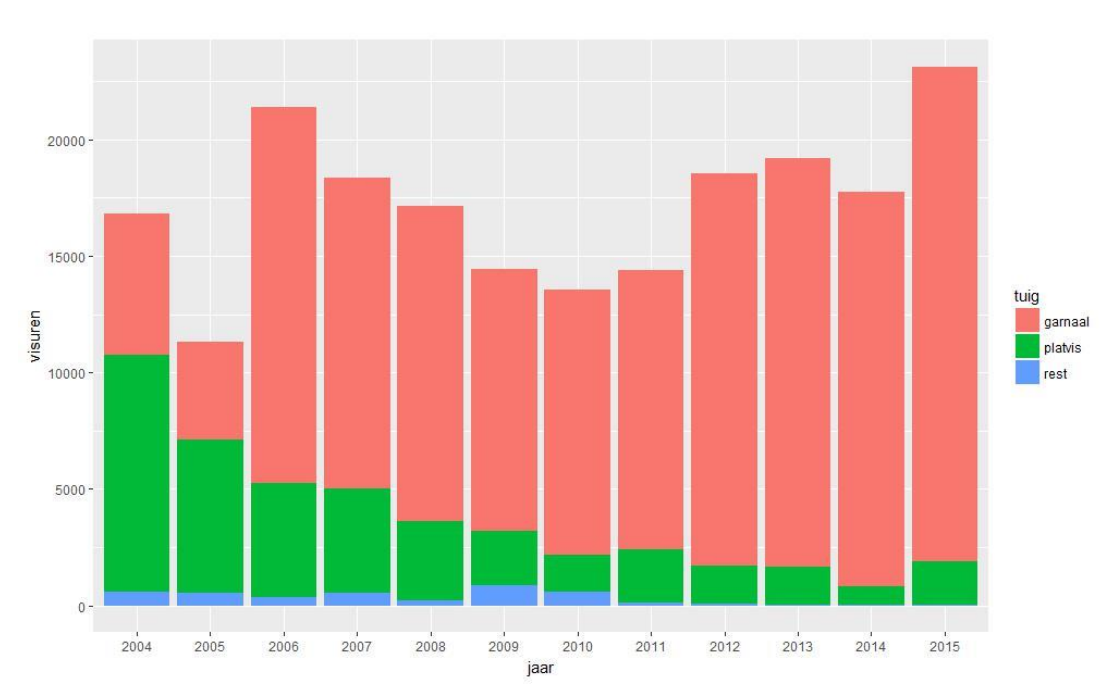

Figuur 0-23 Totale inspanning (visuren) in de Voordelta tussen 2004-2015 van de 68 schepen die met platvistuig gevist hebben, opgedeeld naar gebruikt tuigtype.

Komt de afname in het aandeel platvisvisserij door een wisseling van schepen van platvisvisserij naar garnalenvisserij? Om dit te onderzoeken zijn de schepen geselecteerd die tussen 2004 en 2015 met zowel garnalenkor als platviskor in de Voordelta hebben gevist ${ }^{10}$. In Figuur 0-24 wordt per schip de inspanning met beide tuigen getoond. Hierbij wordt om privacy redenen geen informatie over scheepsnaam gegeven. Veel van deze schepen hebben maar in enkele jaren in de Voordelta gevist met deze tuigen (Figuur 0-24). De schepen die wel veel jaren in de Voordelta hebben gevist, hebben hoofdzakelijk met garnalentuig gevist en vrijwel niet met platvistuig. Er zijn maar twee schepen die een duidelijke wissel hebben gemaakt, waarbij voor 2008 voornamelijk met platvistuig werd gevist en erna met garnalentuig (onderste rij $6^{\mathrm{e}}$ schip, bovenste rij $4^{\mathrm{e}}$ schip).

Samengevat is de afname van de platvisvisserij dus niet veroorzaakt door een toename van het aantal schepen dat met garnalentuig vist. De merendeel van de schepen vist in de hele tijdreeks hoofdzakelijk met garnalentuig.

\footnotetext{
${ }^{10}$ Het aantal schepen komt niet helemaal overeen tussen hoofdstuk 2.1.4 (40 schepen) en hier (41 schepen): Dit wordt veroorzaakt door de andere dataset waar mee gewerkt moet worden. Het $5^{\mathrm{e}}$ schip op de onderste rij komt niet voor in de analyses van hoofdstuk 2.1.4.
} 


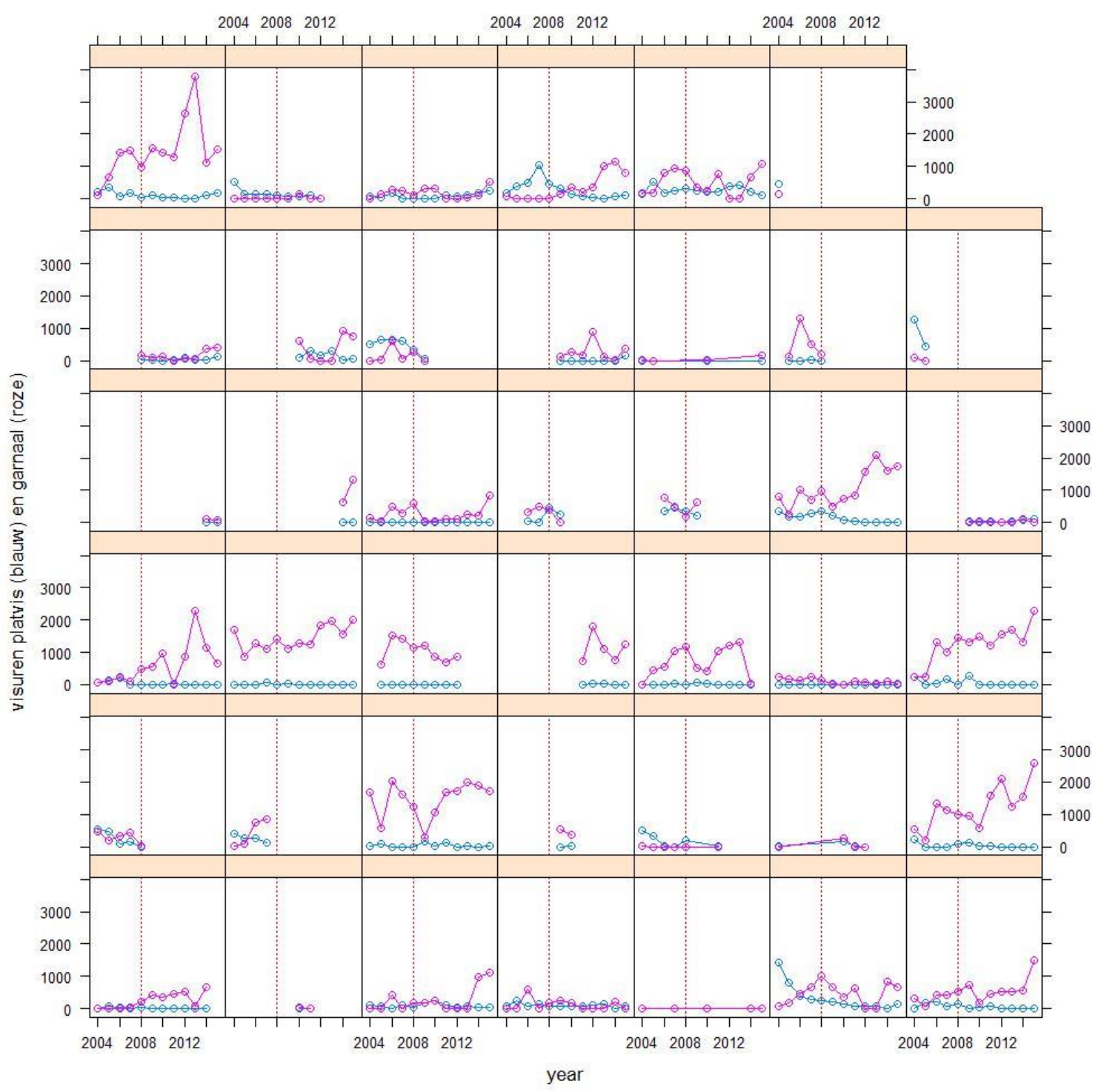

Figuur 0-24 Inspanning in de Voordelta tussen 2004-2015 van de schepen die zowel met platvistuig (blauw) als met garnalentuig (roze) gevist hebben. De rode verticale lijn is 2008; het jaar waarin het Bodembeschermingsgebied is ingesteld. 


\section{$4 \quad$ Trends in aanlandingen}

\subsection{Platviskotters in de Voordelta}

\subsubsection{Absolute aanlandingen}

De 68 platviskotters die tussen 2004 en 2015 in de Voordelta hebben gevist, landden in die jaren 2.929 ton vis en schelp/schaaldieren aan uit de Voordelta (Tabel 0-9). Deze bestond uit 44 soorten $^{11}$. De meest aangelande soort is bot, welke $44.5 \%$ van de totale aanlandingen uitmaakt. Bot, tong (26.4\%), schar (11.8\%) en schol (11.3\%) vormen $94.1 \%$ van de totale aanlandingen tussen 2004 en 2015. Gedetailleerdere analyses hieronder focussen daarom ook op deze vier soorten. Voor de absolute aanlandingen per soort per jaar voor alle soorten, zie Appendix 2.

Tabel 0-9 Totale aanlandingen tussen 2004-2015 van de platviskotters uit de Voordelta, en de soorten die minimaal $1 \%$ van de aanlandingen uitmaken. Voor de aanlandingen per soort per jaar, zie Appendix 2.

\begin{tabular}{llll}
\hline $\begin{array}{l}\text { Soort } \\
\text { totaal }\end{array}$ & Ton & \% & Cumulatief \% \\
bot & 2929 & & \\
tong & 1305 & 44.5 & 44.3 \\
schar & 774 & 26.4 & 71.0 \\
schol & 346 & 11.8 & 82.8 \\
kabeljauw & 331 & 11.3 & 94.1 \\
tarbot & 34 & 1.2 & 95.2 \\
\hline
\end{tabular}

De hoeveelheid aangelande vis is -zoals de hoeveelheid inspanning- sterk afgenomen vanaf 2004 (Figuur 0-25). In 2004 landen de platviskotters meer dan 850 ton vis aan, maar vanaf 2009 fluctueert de hoeveelheid tussen 76-166 ton. Bij alle vier prominente aangelande soorten is hetzelfde patroon zichtbaar, met hoge aanlandingen in de eerste jaren en consistent lage aanlandingen in de laatste jaren.

\footnotetext{
${ }^{11}$ Alleen soorten waarvan minimaal 50 kilogram wordt aangevoerd hoeven gerapporteerd te worden in de logboeken. Voor aangelande soorten die consequent in zeer lage hoeveelheid worden gevangen zijn geen gegevens beschikbaar.
} 

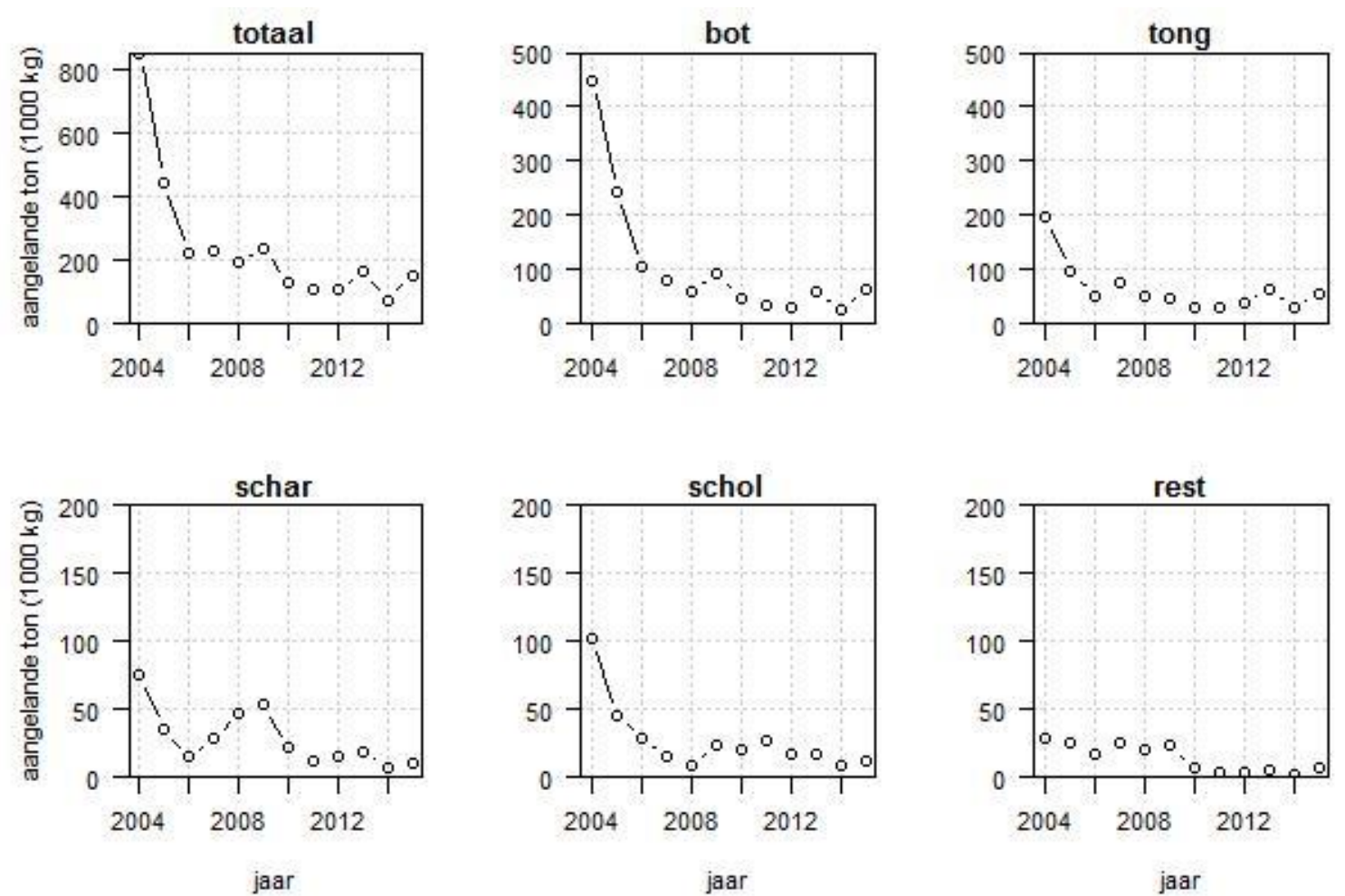

Figuur 0-25. De hoeveelheid aangelande ton vis uit de Voordelta van de platviskotters die tussen 2004-2015 in de Voordelta actief zijn geweest.

\subsubsection{Commercieel vangstsucces}

Het totale vangstsucces (ton per visuur) fluctueert tussen jaren maar lijkt geen duidelijke trend te vertonen
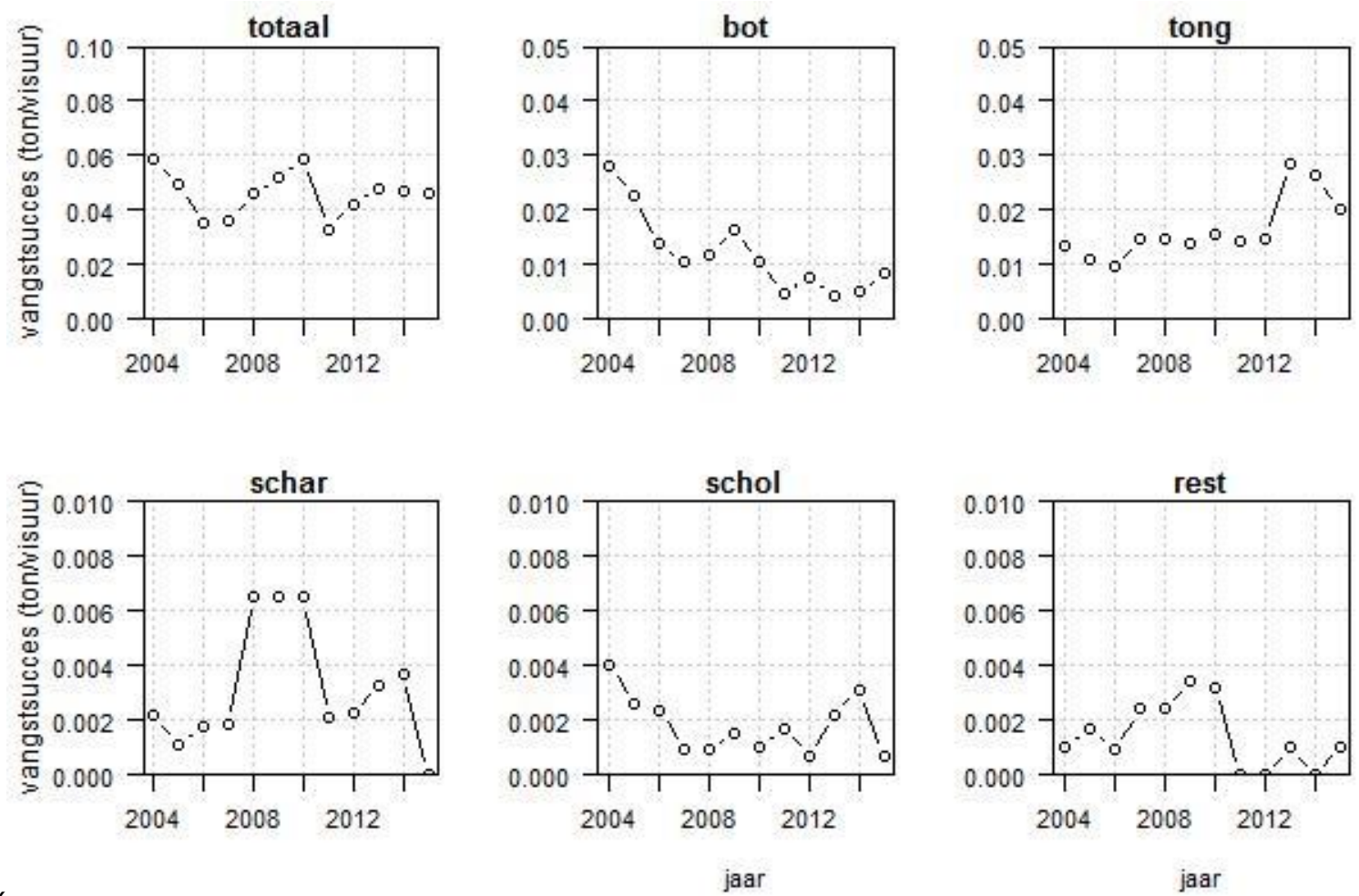

Figuur 0-26). Het vangstsucces van bot neemt sterk af over de hele tijdserie, en ook het vangstsucces van schol lijkt iets af te nemen. Het vangstsucces van tong neemt toe sinds 2012. Dit laatste zou kunnen samenhangen met het gebruik van de puls sinds 2011; deze leidt met name tot betere tongvangsten. Sinds 2011 is het vangstsucces voor de overige soorten minimaal, ook dit zou wellicht 
met het gebruik van de puls te maken kunnen hebben. Schar vertoont sterke fluctuaties maar zonder duidelijke trend.

Bij het interpreteren van deze vangstsuccessen moet onthouden worden dat platviskotters hoofdzakelijk gericht zijn op tong. De overige gevangen soorten zijn bijvangst.
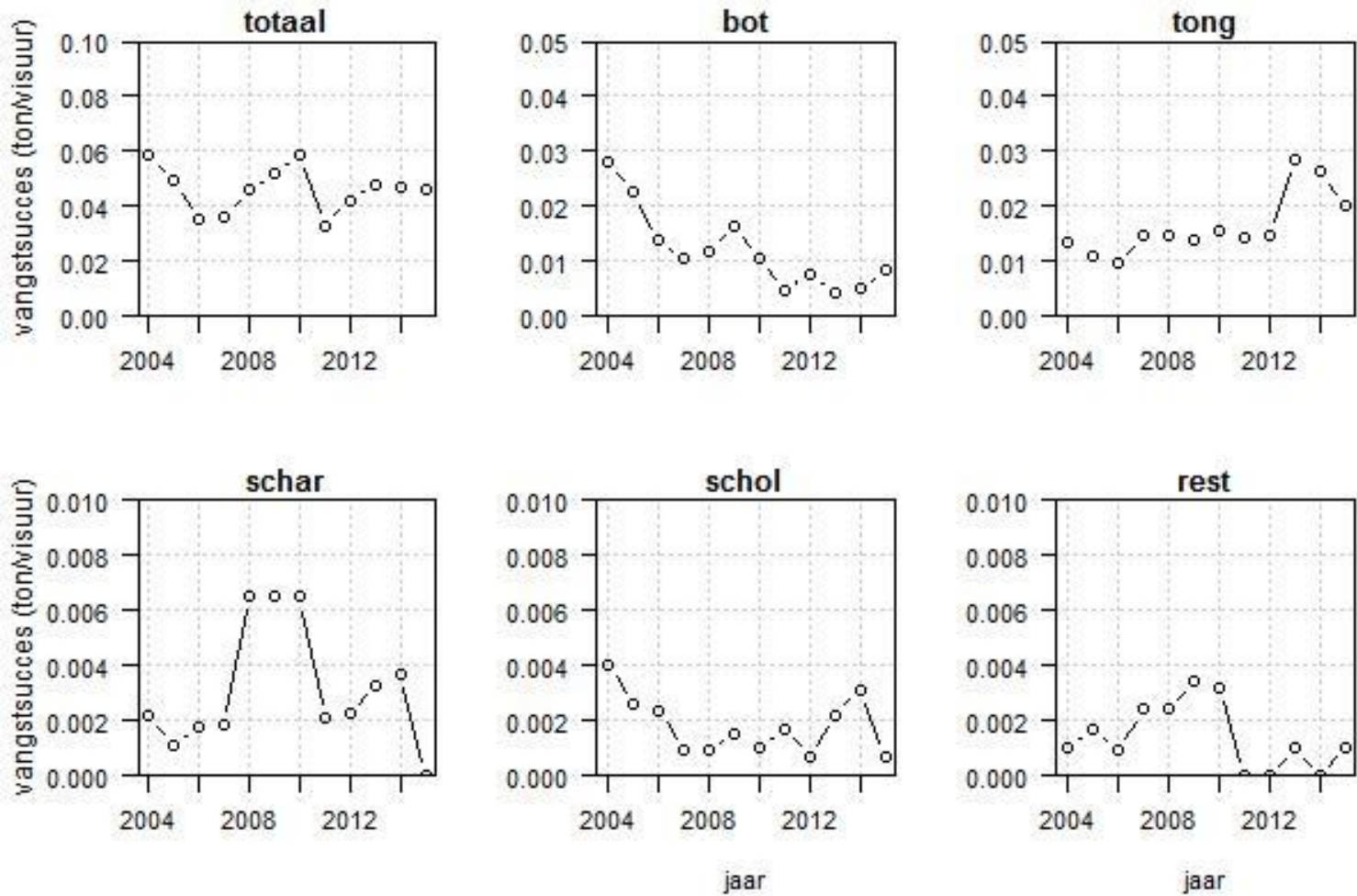

Figuur 0-26. Het vangstsucces (ton per visuur) in de Voordelta van de 68 platviskotters die tussen 2004-2015 in de Voordelta actief zijn geweest.

\subsubsection{Aanlandingen Noordzeebreed}

De 68 platviskotters die tussen 2004 en 2015 in de Voordelta hebben gevist, landden in die jaren in de gehele Noordzee 40.437 ton vis aan (Tabel 0-10). Hiervan is $7.2 \%$ in de Voordelta opgevist. De aanlandingen in de Voordelta beslaan dus maar een klein deel van de totale aanlandingen. De vier soorten die het merendeel van de aanlandingen uit de gehele Noordzee uitmaken zijn dezelfde als die in de Voordelta; schol, schar, tong en bot. Alleen het relatief belang verschilt; zo is in de gehele Noordzee tong de meest gevangen soort, en in de Voordelta bot.

Tabel 0-10 Totale aanlandingen van de 68 platviskotters in de gehele Noordzee (inclusief de Voordelta) tussen 2004-2015, en de soorten die minimaal $1 \%$ van de aanlandingen uitmaken.

\begin{tabular}{llll}
\hline Soort & Ton & \% & Cumulatief \% \\
totaal & 40437 & & \\
tong & 11825 & 29.2 & 29.2 \\
bot & 10060 & 24.9 & 54.1 \\
schol & 9702 & 24.0 & 78.1 \\
schar & 5464 & 13.5 & 91.6 \\
tarbot & 890 & 2.2 & 93.8 \\
kabeljauw & 650 & 1.6 & 95.4 \\
griet & 535 & 1.3 & 96.8 \\
rode poon & 453 & 1.1 & 97.9 \\
\hline
\end{tabular}

De patronen in aanlandingen verschillen tussen de Noordzee en de Voordelta (Figuur 0-27). Er is in het algemeen in de Noordzee geen afname sinds 2004: de aanlandingen fluctueren tussen opeenvolgende jaren, maar er is geen trend. Botaanlandingen nemen wel af. Het aandeel 
aanlandingen uit de Voordelta neemt sterk af tot grofweg 2009, waarna het stabiliseert (Figuur 0-28), gelijk aan de patronen in het aandeel inspanning (Figuur 0-17).
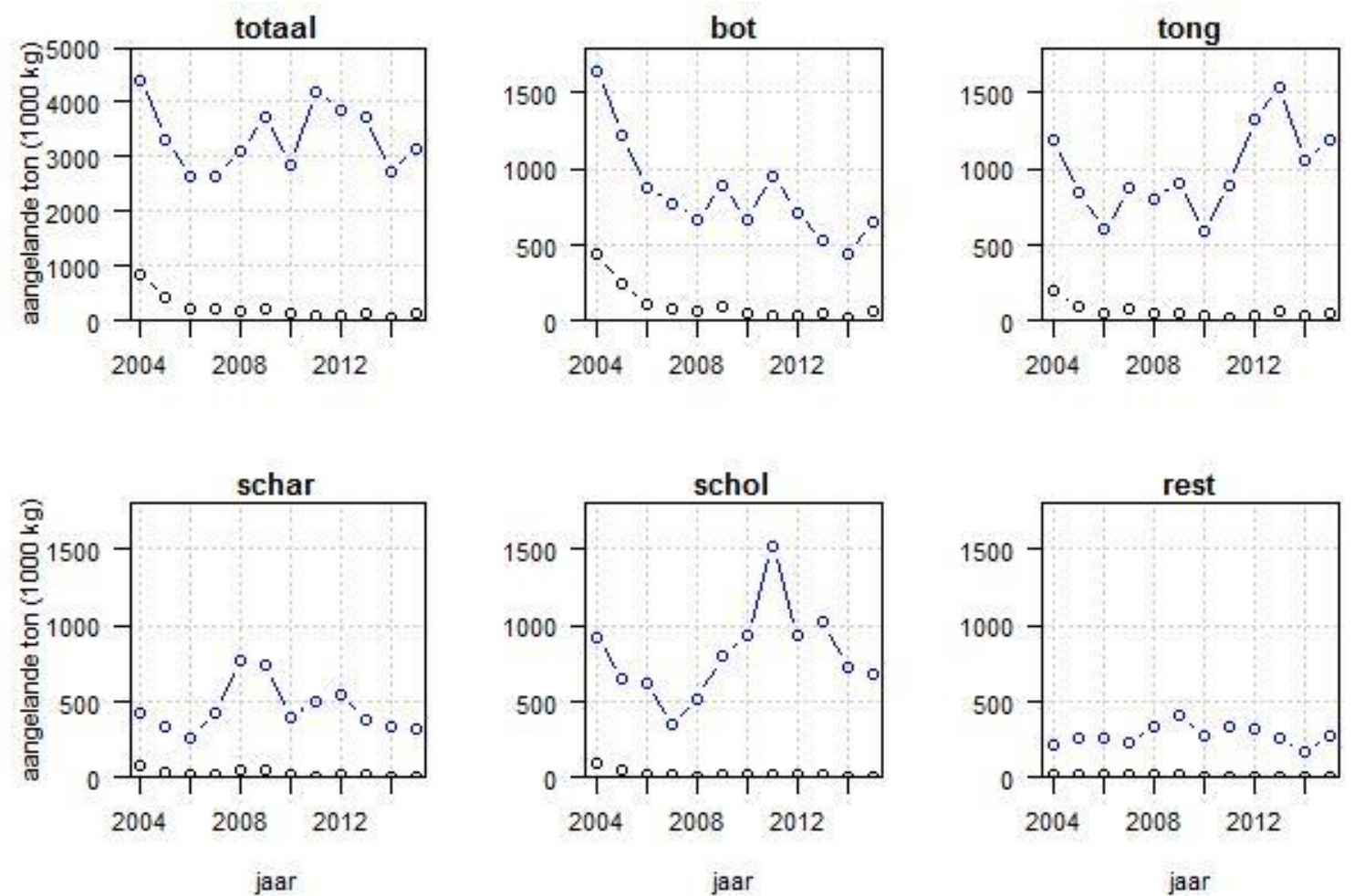

Figuur 0-27 Aanlanding van de 68 platviskotters die tussen 2004-2015 in de Voordelta actief zijn geweest: in de gehele Noordzee (blauw) en in de Voordelta (zwart).
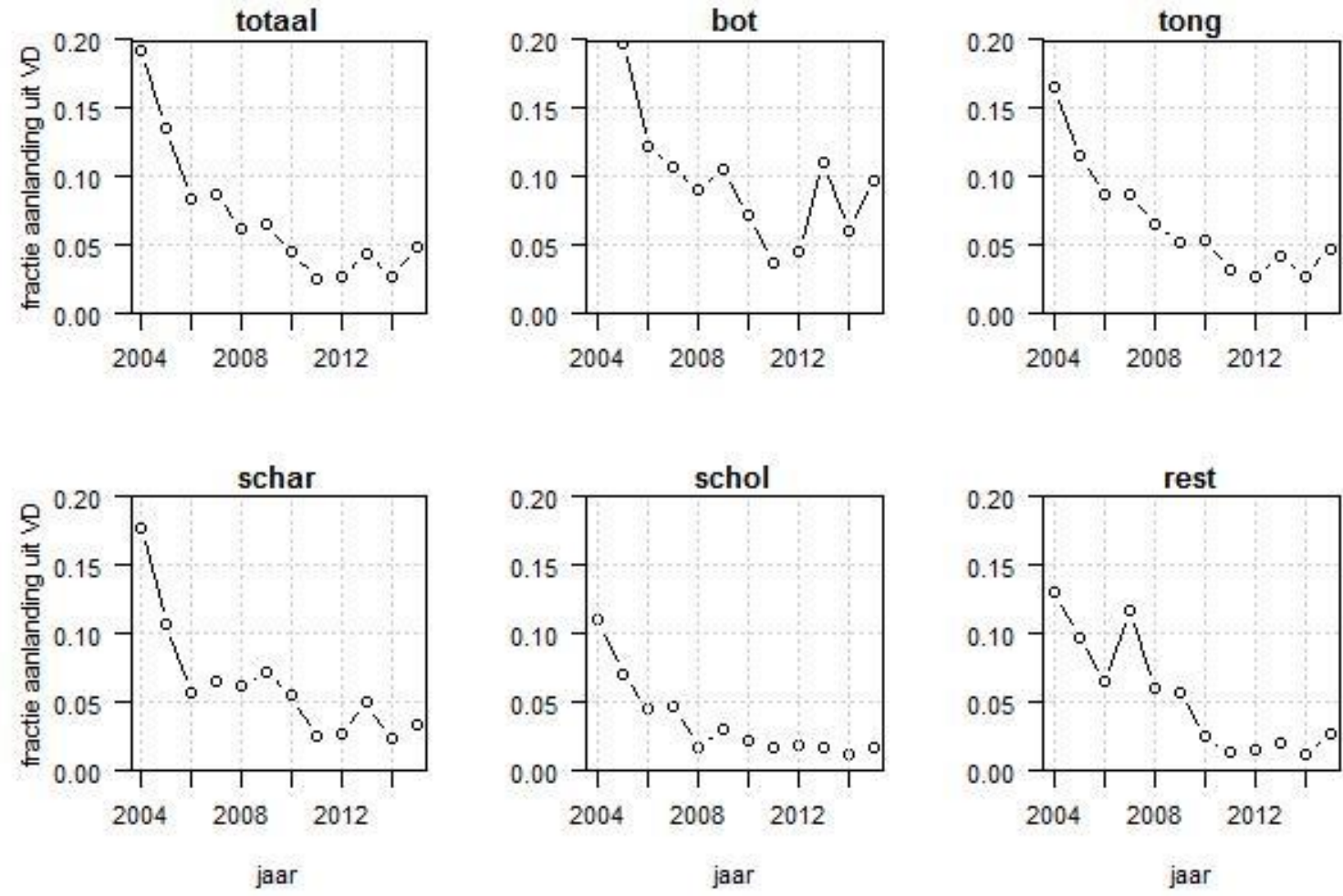

Figuur 0-28. Het aandeel aanlanding uit de Voordelta van de 68 platviskotters die tussen 2004-2015 in de Voordelta actief zijn geweest, van de gehele (Noordzeebrede) visserij van deze kotters. 
Het vangstsucces van tong, de doelsoort van de vloot, vertoont een gelijke trend Noordzeebreed en in de Voordelta, met een iets hoger vangstsucces in de Voordelta (Figuur 0-29). Het vangstsucces van de overige soorten vertoont andere patronen in de Noordzee dan in de Voordelta. Het totale vangstsucces in de Voordelta ligt voor 2011 gemiddeld hoger dan Noordzeebreed. Het vangstsucces van bot is veel hoger in de Voordelta: dit is te verwachten aangezien deze soort dicht op de kust leeft. De achteruitgang in het vangstsucces van bot in de Voordelta is ook niet Noordzeebreed terug te zien, maar dit kan samenhangen met het zeer geringe vangstsucces ( $<0.005$ ton per visuur) Noordzeebreed. Het vangstsucces van schol is juist hoger Noordzeebreed. Bij schol is ook de trend markant verschillend: een toename in de Noordzee maar een afname in de Voordelta.
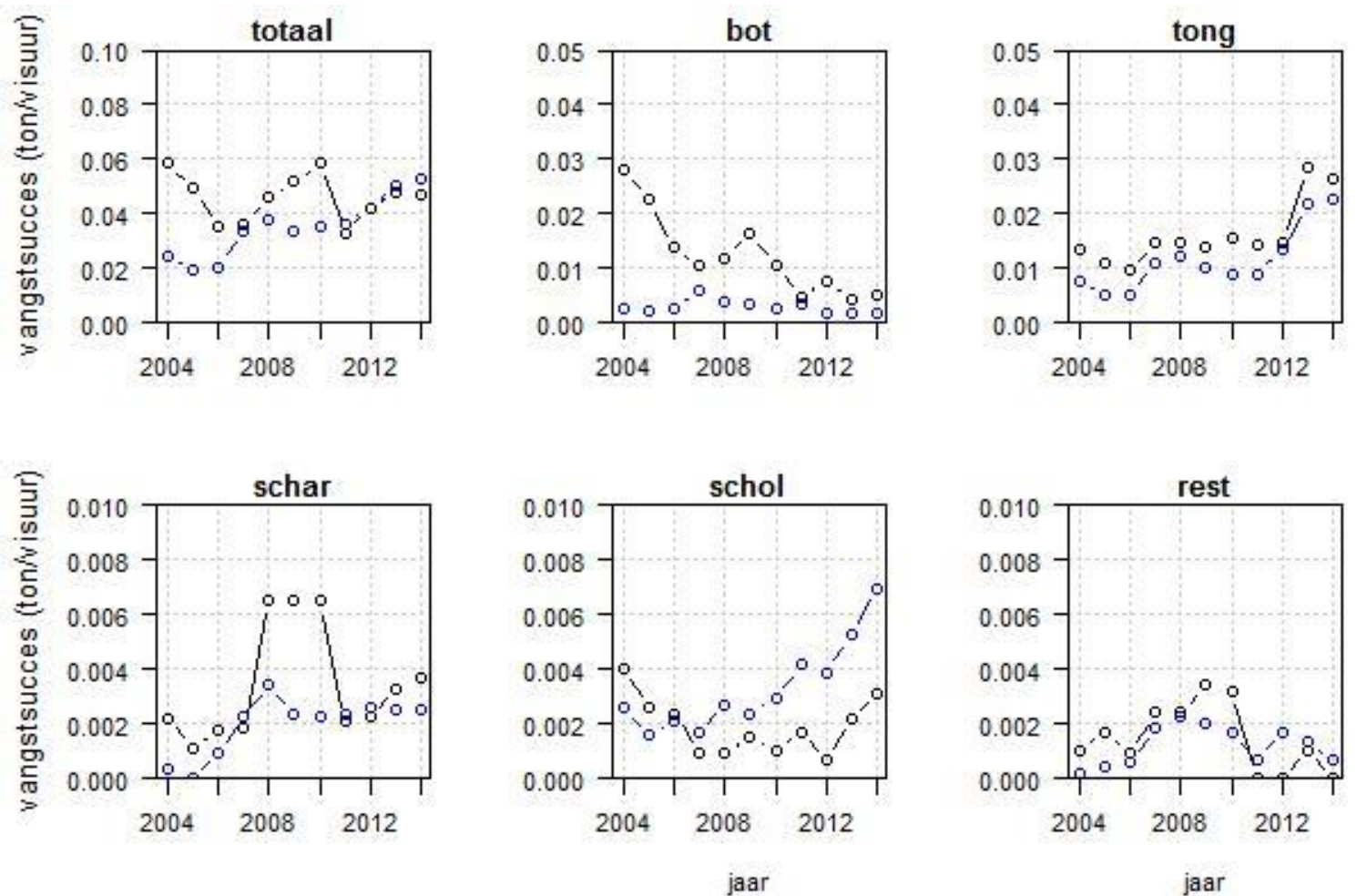

Figuur 0-29. Het vangstsucces (ton per visuur) van de 68 platviskotters die tussen 2004-2015 in de Voordelta actief zijn geweest: in de gehele Noordzee (blauw) en in de Voordelta (zwart). 


\subsubsection{Lange termijn trends}

\section{Lange termijn trends in de Voordelta}

Goede logboekgegevens van de platviskotters zijn beschikbaar vanaf 1998 voor ICES-kwadrant 32F3 (zie ook Figuur 1-1), waar de Voordelta onderdeel van is. Deze gegevens worden gebruikt voor de analyse van lange termijn trends in aanlandingen in de Voordelta. VMS-gegevens waarmee Voordeltaspecifieke trends opgewerkt kunnen worden, zijn pas vanaf 2004 beschikbaar. Voor het bekijken van trends over een langere termijn zal dus naar informatie op een hogere ruimtelijke schaal gekeken moeten worden. De logboekinformatie is genoteerd op het niveau van een visreis (en dus niet per vissende VMS-ping) en beschrijt per ICES-kwadrant hoeveel kilogram vis een schip per visreis gevangen heeft. Het kwadrant 32F3 bevat het grootste deel van de Voordelta (een klein deel valt binnen kwadrant 31F3) maar is wel groter dan alleen de Voordelta; vooral de diepere delen van 32F3 vallen niet in de Voordelta (Figuur 0-1). Ook de selectie van schepen die binnen dit gebied hebben gevist is niet helemaal gelijk; vier van de schepen komen niet voor in de gegevensset voor kwadrant $32 F 3$. De set wordt echter alleen gebruikt om naar grove veranderingen door de tijd heen te kijken en niet om absolute verschillen te bekijken.

De belangrijkste aangelande soorten sinds 1998 zijn dezelfde in $32 \mathrm{~F} 3$ als in de Voordelta; bot, tong, schar en schol. De sterke afname in aanlandingen in de Voordelta van 2004 (zwarte lijn in Figuur $0-30)$ naar latere jaren is deel van een langere trend: vanaf 1998 is een sterke afname in aanlandingen uit 32F3 te zien (grijze lijn in Figuur 0-30). Bot en tong laten in 2002-2004 wel nog een piek zien alvorens de daling doorzet. De aanlandingen uit de Voordelta nemen dus al minimaal sinds 1998 af.
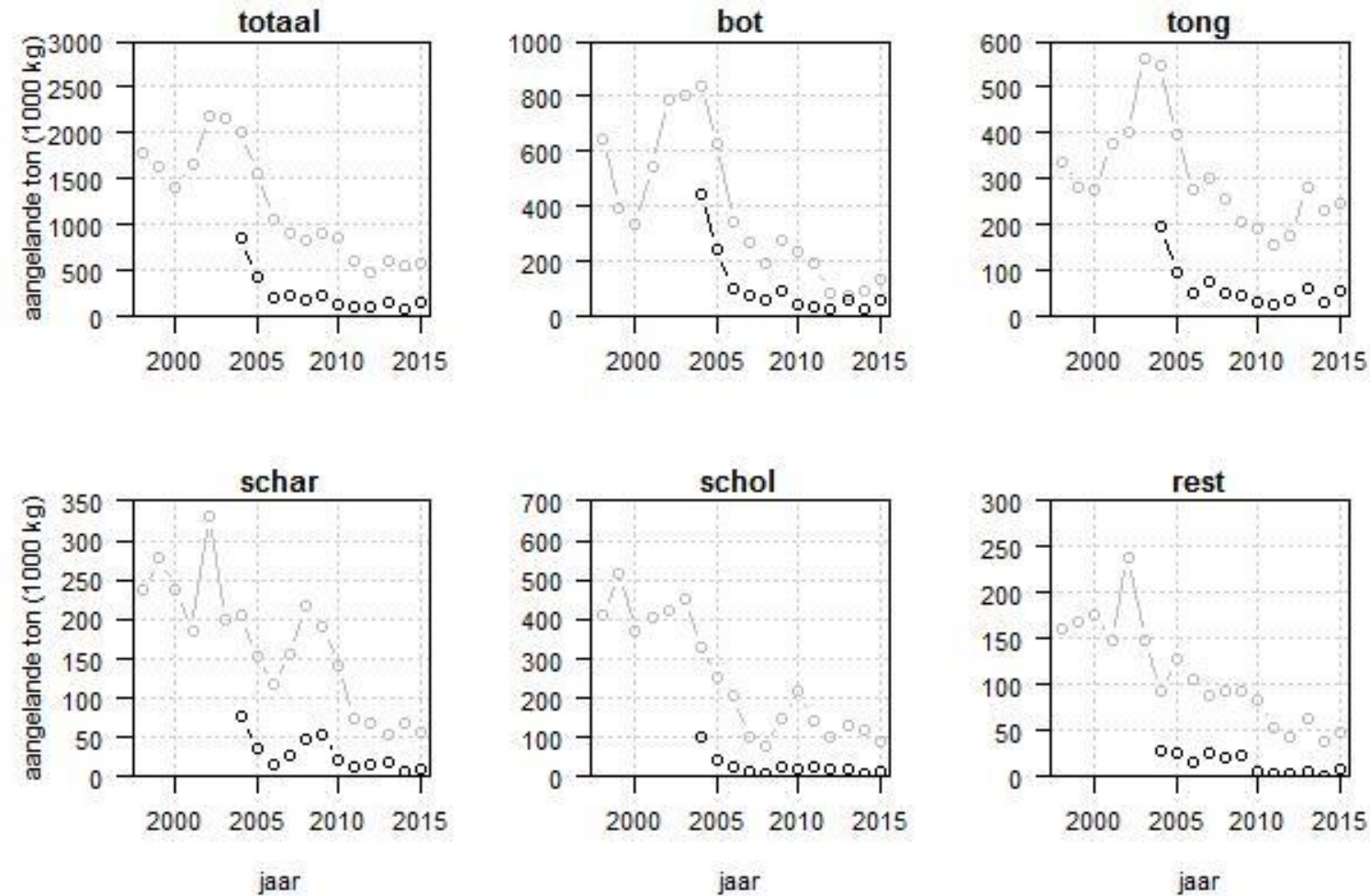

Figuur 0-30. Aanlandingen van de 68 platviskotters die tussen 2004-2015 in de Voordelta actief zijn geweest: in de Voordelta (zwart) en in ICES-kwadrant 32F3 (grijs). ICES-kwadrant 32 F3 beslaat het grootste deel van de Voordelta, maar omvat een groter (en dieper) gebied.

\section{Lange termijn trends Noordzeebreed}

Voor deze schepen is ook gekeken wat het lange termijn belang van de Voordelta (met als proxy ICES-kwadrant 32F3) is qua aanlandingen. Het aandeel van de aanlandingen dat in ICES-kwadrant $32 \mathrm{~F} 3$ wordt gevangen loopt sterk terug voor alle bestanden, tussen 2002 en 2012 (Figuur 0-31. Het belang van de Voordelta in de platvisvisserij nam dus al voor 2004 af. 

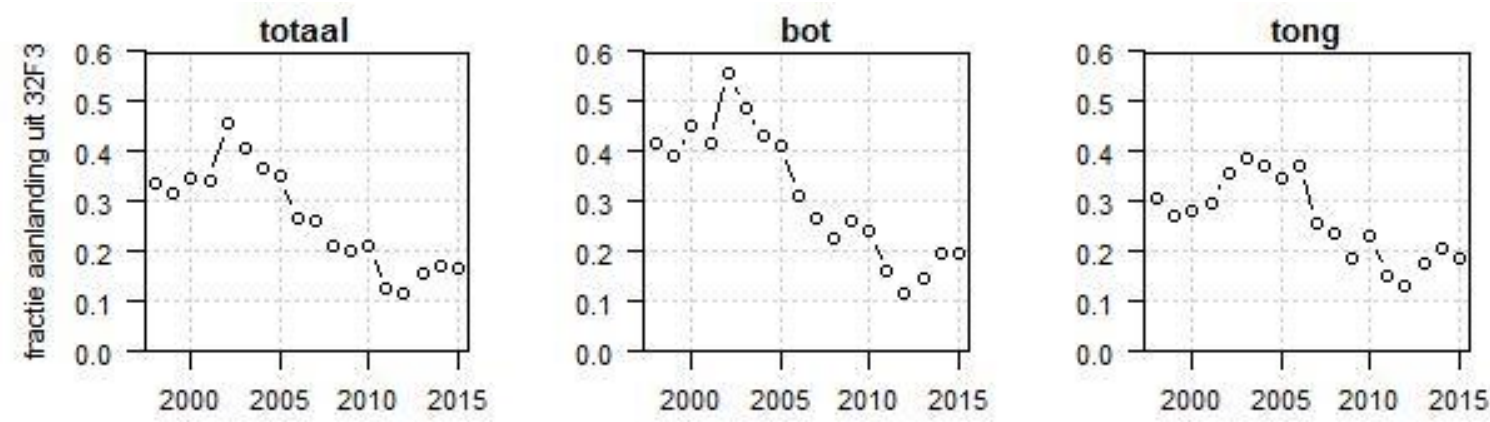

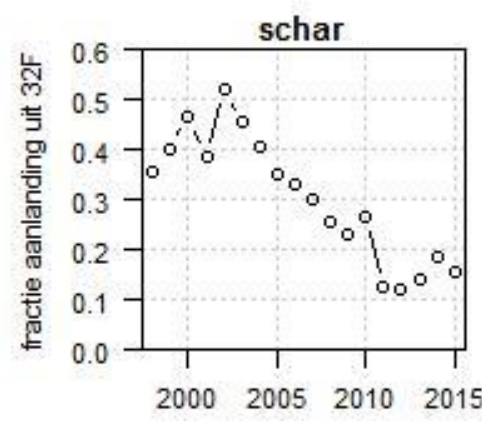

jaar

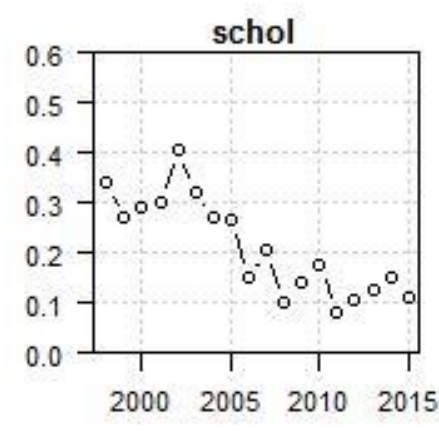

jaar

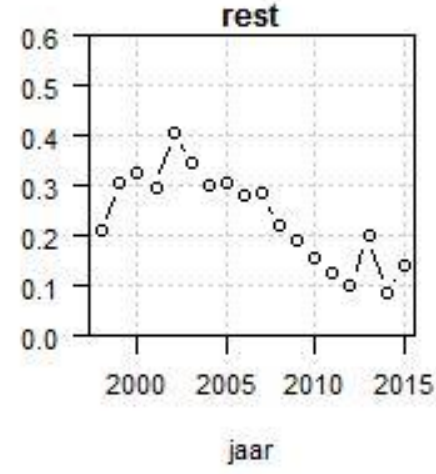

Figuur 0-31. Het aandeel vis aangeland vanuit ICES-kwadrant 32F3, van de gehele aanlandingen van de 68 platviskotters die tussen 2004-2015 in de Voordelta actief zijn geweest.

\subsection{Garnalenkotters in de Voordelta}

Niet alle logboekengegevens van garnalenkotters zijn compleet beschikbaar gesteld vanuit de NVWA/RVO. Vanuit verschillende gegevensbronnen is logboekinformatie over een groot deel van de vloot verzameld, maar de logboekgegevens van een aantal schepen missen. Zo zijn geen aanlandingsgegevens beschikbaar voor een aantal garnalenkotters tot nu toe en voor 2004 en 2005 zijn vrijwel geen logboekgegevens beschikbaar voor de hele vloot. In totaal zijn van $12 \%$ van de visreizen geen aanlandingsgegevens beschikbaar, vrijwel allemaal in 2004 en 2005. Representatieve aanlandingsreeksen beginnen dan ook in 2006 en gelden alleen voor de 69 kotters waar wel aanlandingsgegevens voor zijn. De gegevens zijn ook meer indicatief voor de absolute hoeveelheden en dienen vooral voor het onderscheiden van patronen.

\subsubsection{Absolute aanlandingen}

De 69 garnalenkotters met aanlandingsgegevens tussen 2006 en 2015 in de Voordelta, hebben in die jaren 10.454 ton garnaal uit de Voordelta gevist (Tabel 0-11). Garnaal vormt 93.1\% van de totale aanlandingen. Daarnaast bestond de aanlandingen uit 41 andere soorten ${ }^{12}$. Alleen schar (3.5\%) en bot $(1.7 \%)$ maken meer dan $1 \%$ van de totale aanlandingen uit. Garnaal is de dominante soort in de aanlandingen en de gedetailleerdere analyses hieronder focussen daarom ook alleen op garnaal.

De hoeveelheid aangelande garnaal was redelijk stabiel tot en met 2013 maar steeg sterk in 2014 en 2015 (

Figuur 0-32). Dit patroon loopt niet parallel met de inspanning, maar wel met het aantal actieve garnalenkotters (Figuur 0-18). Tussen 2006-2013 landen de kotters 500-1000 ton garnaal aan en in

\footnotetext{
${ }^{12}$ Alleen soorten waarvoor minimaal 50 kilogram wordt aangevoerd hoeven gerapporteerd te worden in de logboeken. Voor aangelande soorten die consequent in zeer lage hoeveelheid worden gevangen zijn geen gegevens beschikbaar.
} 
2014-2015 ca. 1500 ton. Voor de absolute aanlandingen per soort per jaar voor alle soorten, zie Appendix 2.

Tabel 0-11 Totale aanlandingen van de 69 garnalenkotters met aanlandingsgegevens uit de Voordelta tussen 2006-2015, en de soorten die minimaal $1 \%$ van de aanlandingen uitmaken. Voor de aanlandingen per soort per jaar, zie Appendix 2.

\begin{tabular}{llll}
\hline $\begin{array}{l}\text { Soort } \\
\text { totaal }\end{array}$ & Ton & \% & Cumulatief \% \\
garnaal & 11.235 & & \\
schar & 10.454 & 93.1 & 93.1 \\
bot & 397 & 3.4 & 96.6 \\
\hline
\end{tabular}
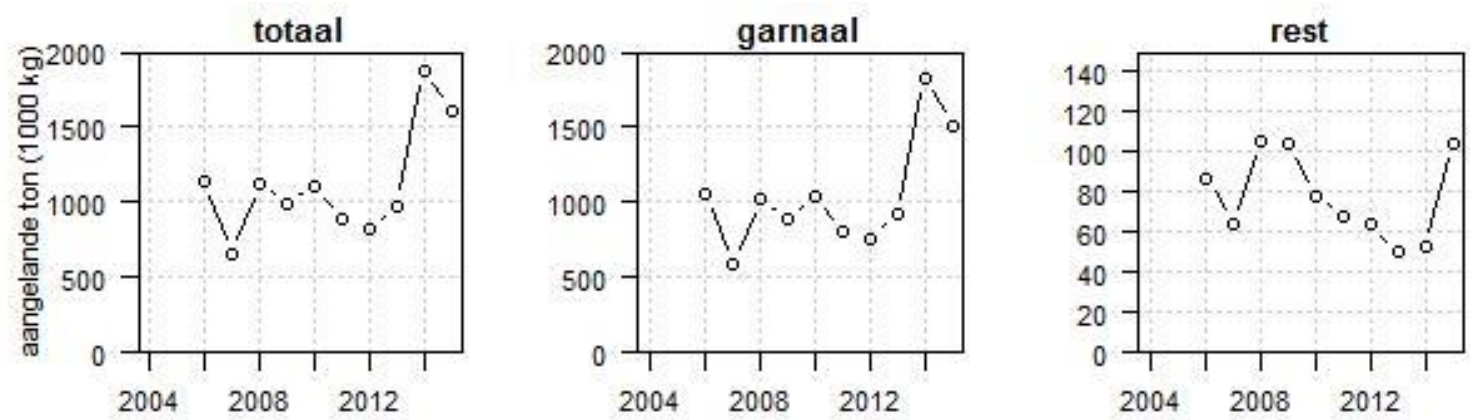

Figuur 0-32. Aanlanding uit de Voordelta van de 69 garnalenkotters tussen 2006-2015.

\subsubsection{Commercieel vangstsucces}

Het totale vangstsucces garnaal (ton per visuur) fluctueert tussen 2006 en 2015 maar zonder trend (Figuur 0-33). Het vangstsucces van de overige soorten is relatief laag en vertoont ook geen trend.
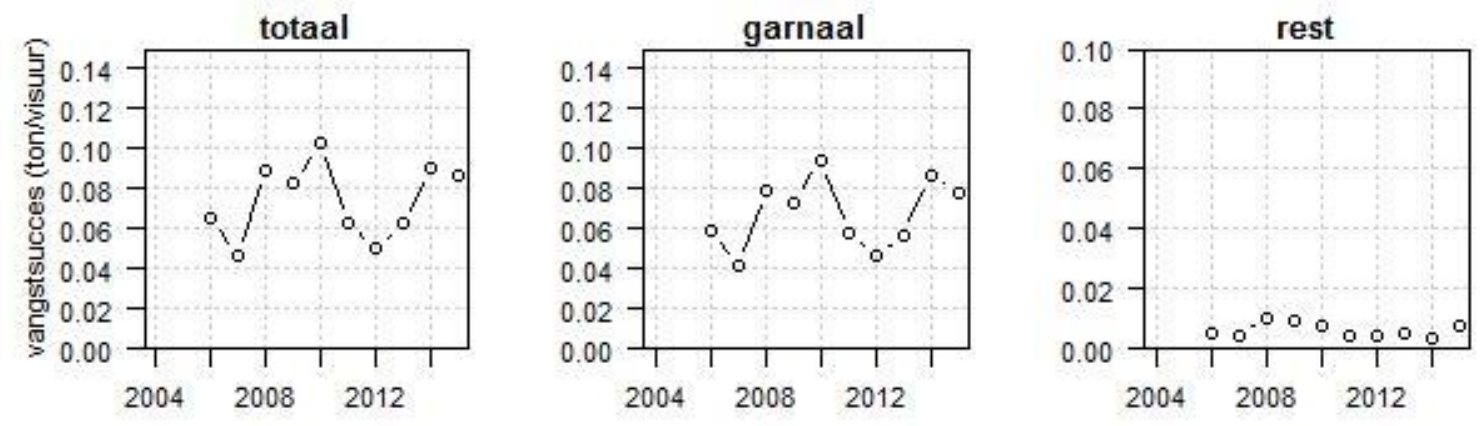

jaar

Figuur 0-33. Het vangstsucces (ton per visuur) in de Voordelta van de 69 garnalenkotters met logboekgegevens tussen 2006-2015. 


\section{$5 \quad$ Trends in discards}

In tegenstelling tot de aanlandingen worden discards niet genoteerd in de logboeken. Informatie over discards wordt verkregen uit speciale discardmonitoringprogramma's die onderdeel uitmaken van het Wettelijke Onderzoek Taken (WOT) programma dat Wageningen Marine Research uitvoert in opdracht van de overheid. Deze programma's zijn niet zeer uitgebreid en er is qua platvisvisserij geen enkel bemonsteringspunt in de Voordelta geweest (zie hoofdstuk 1.3.2). Qua garnalenvisserij zijn hooguit 12 bemonsteringspunten per jaar beschikbaar. Voor beide typen visserij zijn voor minimaal de helft van de jaren geen bemonsteringspunten beschikbaar. Er wordt daarom gewerkt met de aanname dat de verhouding tussen discards en inspanning gelijk is door de jaren heen, en tussen aangrenzende gebieden. Voor de benthosschattingen (buiten garnaal om) komen hier nog meer onzekerheden bovenop, die ertoe leiden dat deze benthosschattingen minimale schattingen zijn; waarschijnlijk is de hoeveelheid benthosdiscarding hoger (zie hoofdstuk 1.3.2). Het berekende vangstsucces van de discards is dan ook een grove schatting van het daadwerkelijk vangstsucces qua discards. Dit geschatte vangstsucces is vervolgens opgewerkt naar absolute hoeveelheid discards, door te vermenigvuldigen met de hoeveelheid inspanning zoals in hoofdstuk 3 uiteengezet. Ook deze absolute hoeveelheid discards zijn dus zeer grove schattingen.

\section{$5.1 \quad$ Platvisvisserij}

\subsubsection{Vis}

Voor de jaren 2004-2015 wordt geschat dat er door de platviskotters die in de Voordelta hebben gevist 504.7 ton visdiscards overboord gegooid werd (Tabel 0-12). Deze discards bestonden uit 62 soorten vis. De meest gediscarde vissoort is schar, welke $22.6 \%$ van de totale discards uitmaakt. Schol $(12.1 \%)$, tong $(5.0 \%)$, hondshaai $(4.8 \%)$, bot $(4.7 \%)$ en schar vormen samen bijna de helft van de totale discards tussen 2004 en 2015.

Er werden 62 verschillende soorten vis waargenomen in de discardmonsters. De figuren hieronder focussen op deze meest gediscarde vissoorten (top-20 in gewicht). Voor de absolute discards per soort per jaar voor alle soorten vis, zie Appendix 2.

De totale hoeveelheid discards per jaar neemt -zoals de visserijinspanning- sterk af in de periode 2004-2015 (Figuur 0-34). Deze geschatte afname is ook direct veroorzaakt door de afname in visserijinspanning: er is geen informatie over de discards tussen 2004-2009 beschikbaar en de geschatte relatie tussen discards en inspanning van 2010-2015 is gebruikt om op basis van de hoeveelheid inspanning in 2004-2009 de hoeveelheid discards voor deze jaren te schatten.

Behalve de algemene afname van totale hoeveelheid discards per jaar, is er weinig patroon in de soorten onderling (Figuur 0-35). De sterkste patronen (afname in de eerste jaren van de tijdreeks) worden ook hier veroorzaakt door de inspanningsafname in de beginjaren. 
Tabel 0-12: Totale discardschattingen van vis in de platvisvisserij in de periode 2004-2015 in de Voordelta (top-20 in gewicht).Voor de schattingen per soort per jaar, zie Appendix 2.

\begin{tabular}{lccc}
\hline Soort & Ton & $\%$ & Cumulatief $\%$ \\
\hline Totaal & 504.7 & & \\
Schar & 114.0 & $22.6 \%$ & $22.6 \%$ \\
\hline Schol & 61.0 & $12.1 \%$ & $34.7 \%$ \\
\hline Tong & 25.0 & $5.0 \%$ & $39.6 \%$ \\
\hline Hondshaai & 24.2 & $4.8 \%$ & $44.4 \%$ \\
\hline Bot & 24.0 & $4.7 \%$ & $49.2 \%$ \\
\hline Tarbot & 20.9 & $4.1 \%$ & $53.3 \%$ \\
Wijting & 16.9 & $3.3 \%$ & $56.7 \%$ \\
\hline Zeedonderpad & 16.8 & $3.3 \%$ & $60.0 \%$ \\
\hline Slakdolf & 16.2 & $3.2 \%$ & $63.2 \%$ \\
\hline Kabeljauw & 15.4 & $3.1 \%$ & $66.3 \%$ \\
Adderzeenaald & 14.5 & $2.9 \%$ & $69.1 \%$ \\
\hline Stekelrog & 10.4 & $2.1 \%$ & $71.2 \%$ \\
\hline Haring & 10.1 & $2.0 \%$ & $73.2 \%$ \\
\hline Griet & 10.1 & $2.0 \%$ & $75.2 \%$ \\
\hline Sterrog & 10.0 & $2.0 \%$ & $77.2 \%$ \\
\hline Tongschar & 8.3 & $1.7 \%$ & $78.8 \%$ \\
\hline Zeeprik & 7.8 & $1.5 \%$ & $80.4 \%$ \\
\hline Steenbolk & 6.9 & $1.4 \%$ & $81.7 \%$ \\
\hline Gevlekte lipvis & 6.4 & $1.3 \%$ & $83.0 \%$ \\
\hline Harnasmannetje & 6.3 & $1.2 \%$ & $84.2 \%$ \\
\hline
\end{tabular}

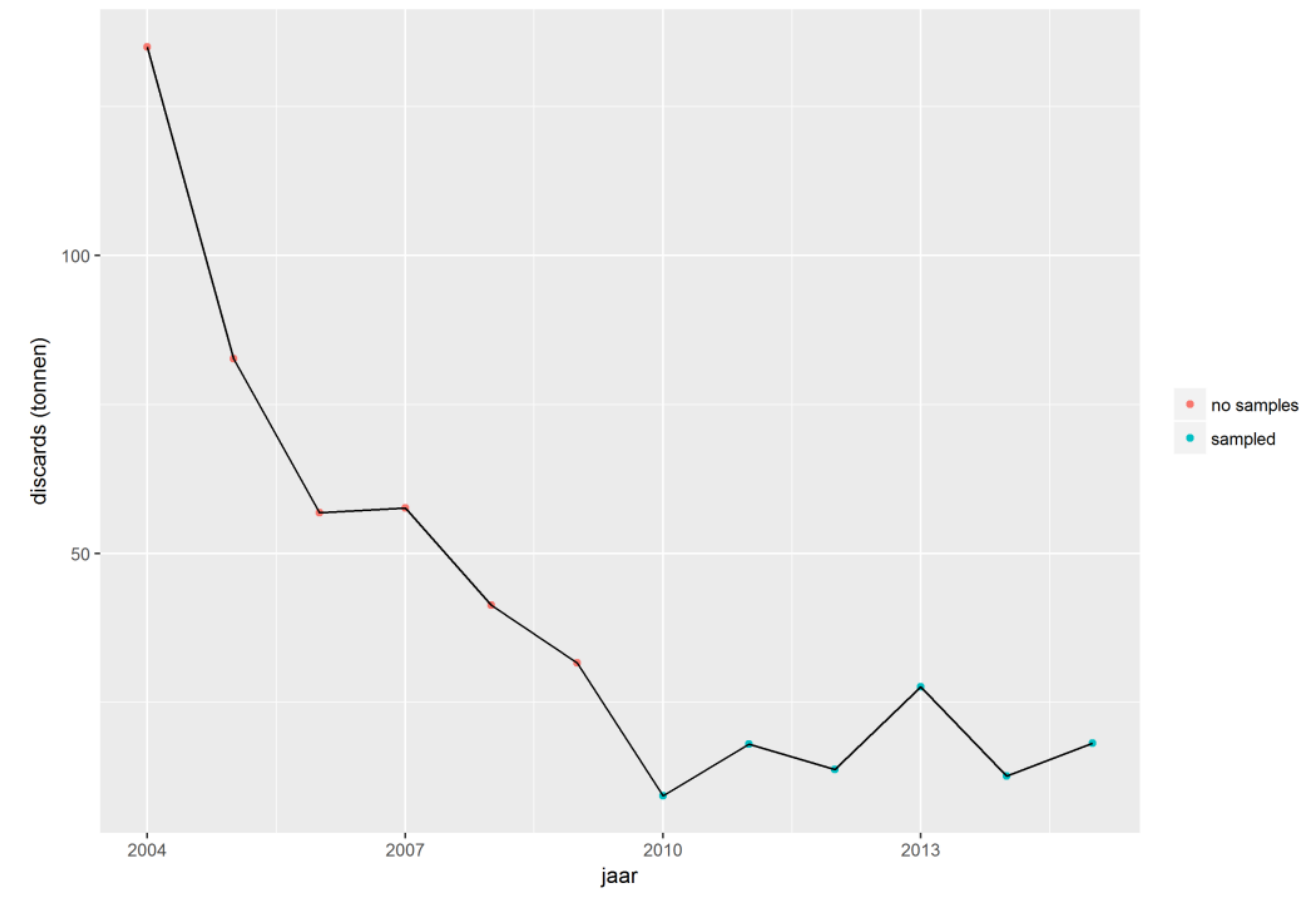

Figuur 0-34: Totale geschatte hoeveelheid visdiscards (ton) uit de platvisvisserij over de periode 2004-2015. Rode punten geven de jaren waar geen monsters beschikbaar. De gegevens uit de jaren met monsters (blauwe punten) zijn gebruikt om de discards voor de jaren zonder monsters op te werken. 


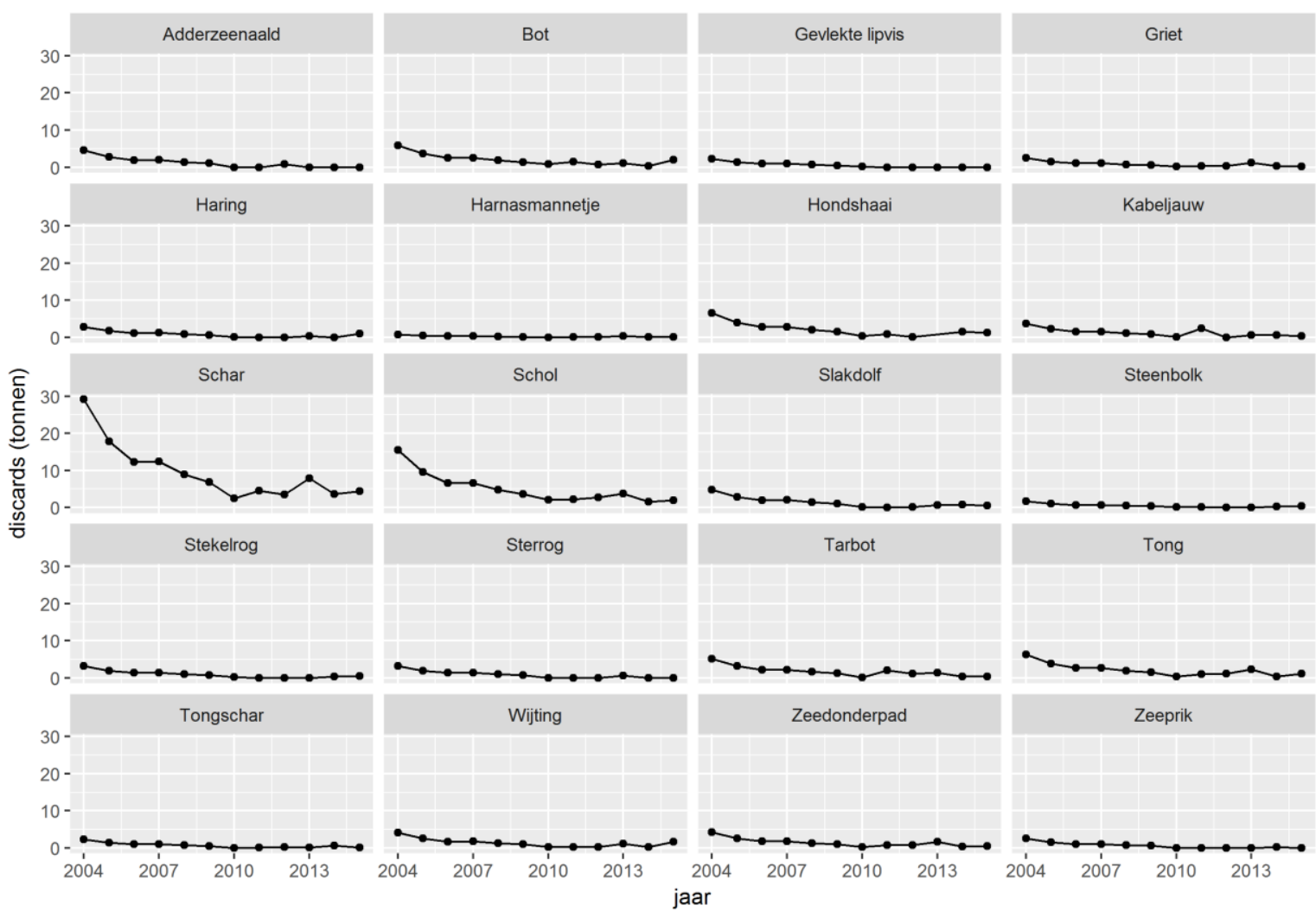

Figuur 0-35: Discardschattingen (ton) voor de meest gediscarde soorten vis in de platvisvisserij over de periode $2004-2015$.

\subsubsection{Benthos}

Voor de jaren 2004-2015 wordt geschat dat er door de platviskotters, die in de Voordelta hebben gevist 394 ton benthosdiscards overboord gegooid werd (Tabel 0-13). Deze discards bestonden uit 38 soorten benthos. Benthosdiscards nemen af door de jaren en lijken de laatste jaren te stabiliseren (Figuur 0-36). De dominante soort in de benthosdiscards is zeester, welke $51 \%$ van de totale discardbiomassa uitmaakt. Deze dominantie speelt gedurende de hele tijdserie (Figuur 0-37); in de laatste jaren wordt vrijwel alleen maar zeester gediscard. Voor de absolute discards per soort per jaar voor alle soorten benthos, zie Appendix 2.

Tabel 0-13: Totale discardschattingen (in tonnen biomassa) van benthos in de platvisvisserij in de periode 2004-2015 in de Voordelta (top-20 in gewicht). Voor de schattingen per soort per jaar, zie Appendix 2.

\begin{tabular}{lccc}
\hline Soort & Ton & \% & Cumulatief \% \\
Totaal & 394.17 & & \\
Zeester & 202.75 & 51 & 51 \\
Slangster & 71.49 & 18 & 70 \\
Gewone zwemkrab & 62.84 & 16 & 86 \\
Zeeappel & 28.52 & 7 & 93 \\
Blauwpootzwemkrab & 5.20 & 1 & 94 \\
Gewone heremietkreeft & 3.89 & 1 & 95 \\
Nonnetje & 3.65 & 1 & 96 \\
Gevlochten fuikhoorn & 2.45 & 1 & 97 \\
Tapijtschelp & 2.24 & 1 & 97 \\
Mossel & 1.69 & $<1$ & 98 \\
Fluwelen zwemkrab & 1.25 & $<1$ & 98 \\
Fluwelen zeemuis & 1.16 & $<1$ & 98 \\
Hartegel & 0.98 & $<1$ & 98 \\
\hline
\end{tabular}




\begin{tabular}{lccc}
\hline Soort & Ton & \% & Cumulatief \% \\
Strandkrab & 0.72 & $<1$ & 99 \\
Stevige strandschelp & 0.65 & $<1$ & 99 \\
Helmkrab & 0.64 & $<1$ & 99 \\
Halfgeknotte strandschelp & 0.53 & $<1$ & 99 \\
Witte dunschaal & 0.51 & $<1$ & 99 \\
Kleine slangster & 0.49 & $<1$ & 99 \\
Grof geribde fuikhoorn & 0.47 & $<1$ & 99 \\
\hline
\end{tabular}

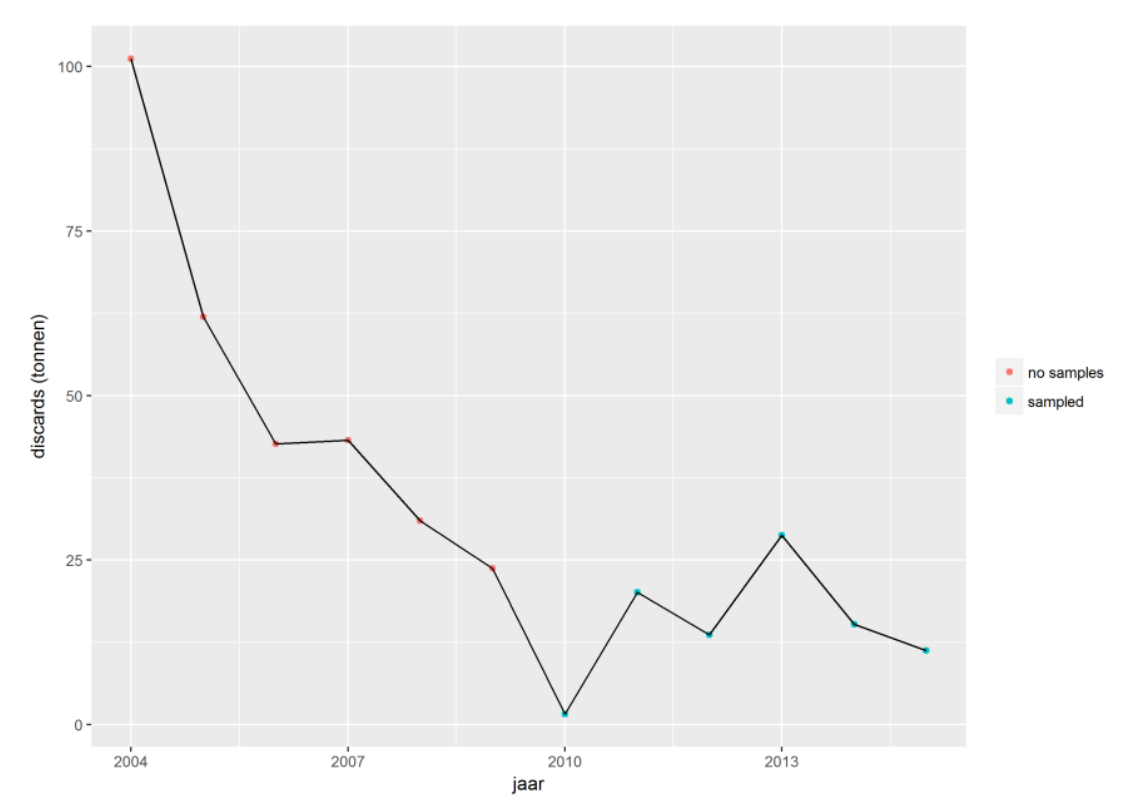

Figuur 0-36 Totale geschatte hoeveelheid benthosdiscards (biomassa in ton) uit de platvisvisserij over de periode 2004-2015. Rode punten geven de jaren waar geen monsters beschikbaar zijn. De gegevens uit de jaren met monsters (blauwe punten) zijn gebruikt om de discards voor de jaren zonder monsters op te werken. 


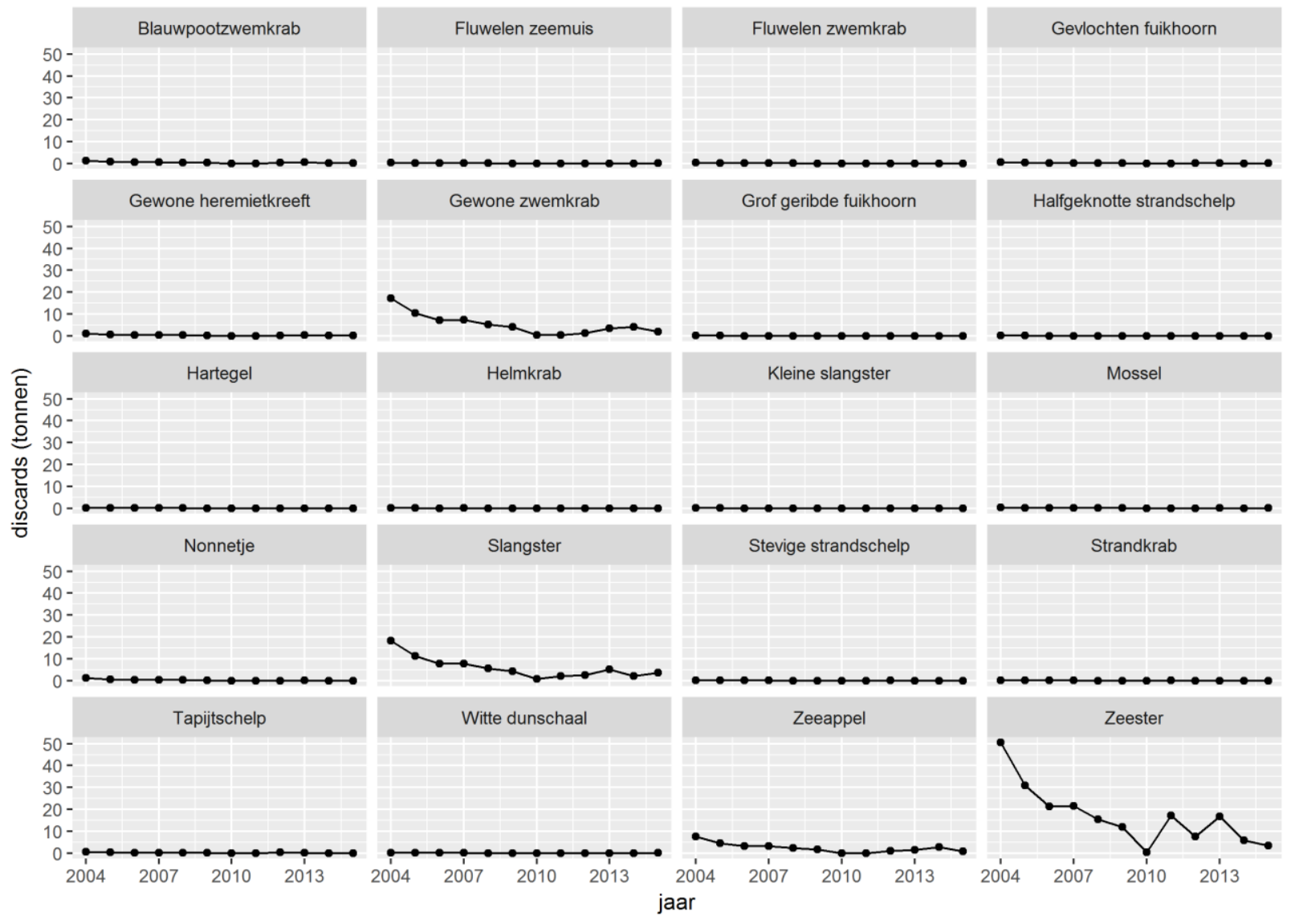

Figuur 0-37 Discardschattingen (in ton biomassa) voor de meest gediscarde soorten benthos over de periode $2004-2015$.

\subsection{Garnalenvisserij}

\subsubsection{Reguliere monitoringsprogramma}

Volgens het discardmonitoringsprogramma gericht op garnalenkotters wordt er voor de periode 20082015 in totaal 10768.8 ton vis- en garnaaldiscards geschat (Tabel 0-14). Deze discards bestonden uit 45 verschillende soorten. De meest gediscarde soort is garnaal, welke $86.1 \%$ van de totale discards uitmaakt. Wijting (4.1\%) en schol $(2.0 \%)$ vormen samen met garnaal de hoofdmoot van de totale discards (qua vis en garnaal) tussen 2004 en 2015. Voor de absolute discards per soort per jaar voor alle soorten vis en benthos, zie Appendix 2.

De totale discards fluctueren sterk tussen de jaren, zonder duidelijk patroon

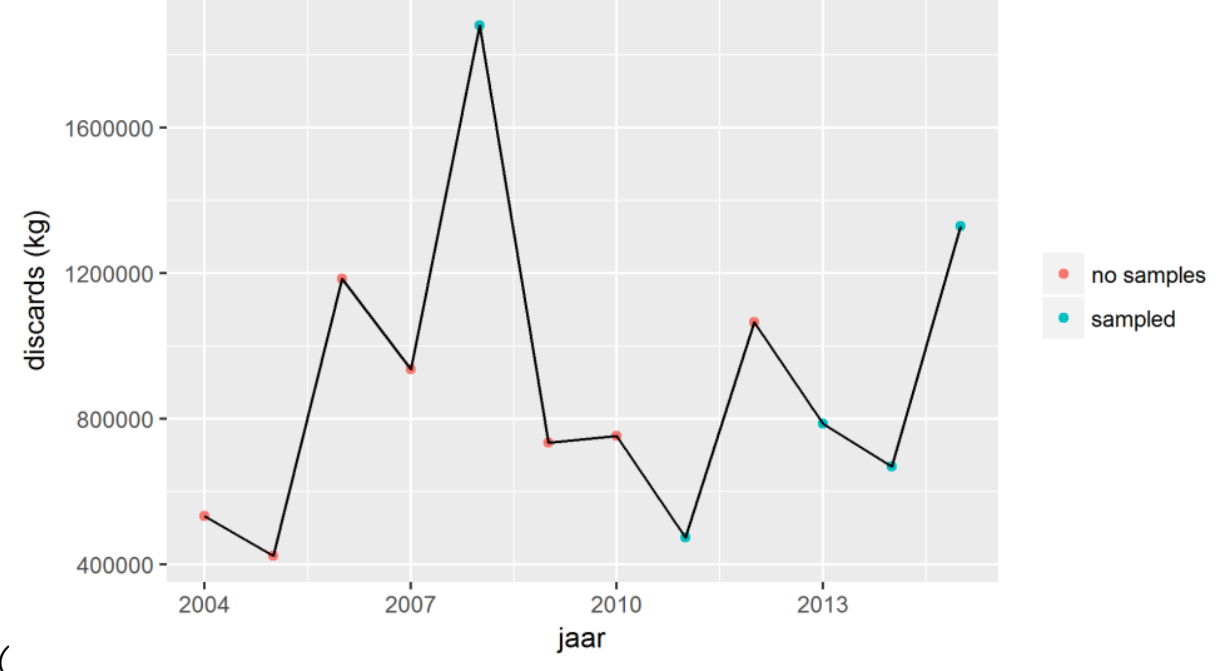


Figuur 0-38). Deze trend is vrijwel identiek aan die van de discards van alleen garnaal.

Nota Bene: Van de benthossoorten is alleen garnaal bemonsterd in de programma's. Voor de overige benthossoorten is geen informatie beschikbaar.

Tabel 0-14: Totale discardschattingen van vis en garnaal in de garnalenvisserij in de periode 2004-2015 in de Voordelta (top-20 in gewicht).

\begin{tabular}{l|ccc}
\hline Soort & Ton & \% & Cumulatief \% \\
\hline Totaal & 10768.8 & & \\
Gewone garnaal & 9268.3 & $86.1 \%$ & $86.1 \%$ \\
Wijting & 436.4 & $4.1 \%$ & $90.1 \%$ \\
Schol & 218.0 & $2.0 \%$ & $92.1 \%$ \\
Grondel & 191.2 & $1.8 \%$ & $93.9 \%$ \\
Haring & 152.7 & $1.4 \%$ & $95.3 \%$ \\
Schar & 96.7 & $0.9 \%$ & $96.2 \%$ \\
Sprot & 58.5 & $0.5 \%$ & $96.8 \%$ \\
Harnasmannetje & 53.2 & $0.5 \%$ & $97.3 \%$ \\
Tong & 47.5 & $0.4 \%$ & $97.7 \%$ \\
Zeedonderpad & 43.7 & $0.4 \%$ & $98.1 \%$ \\
Pitvis & 36.4 & $0.3 \%$ & $98.5 \%$ \\
Dwergbolk & 28.0 & $0.3 \%$ & $98.7 \%$ \\
Spiering & 20.7 & $0.2 \%$ & $98.9 \%$ \\
Dwergtong & 15.8 & $0.1 \%$ & $99.1 \%$ \\
Vijfdradige meun & 12.0 & $0.1 \%$ & $99.2 \%$ \\
Dikkopje & 11.9 & $0.1 \%$ & $99.3 \%$ \\
Bot & 10.4 & $0.1 \%$ & $99.4 \%$ \\
Glasgrondel & 10.1 & $0.1 \%$ & $99.5 \%$ \\
Puitaal & 7.5 & $0.1 \%$ & $99.5 \%$ \\
Schurftvis & 6.1 & $0.1 \%$ & $99.6 \%$ \\
\hline
\end{tabular}

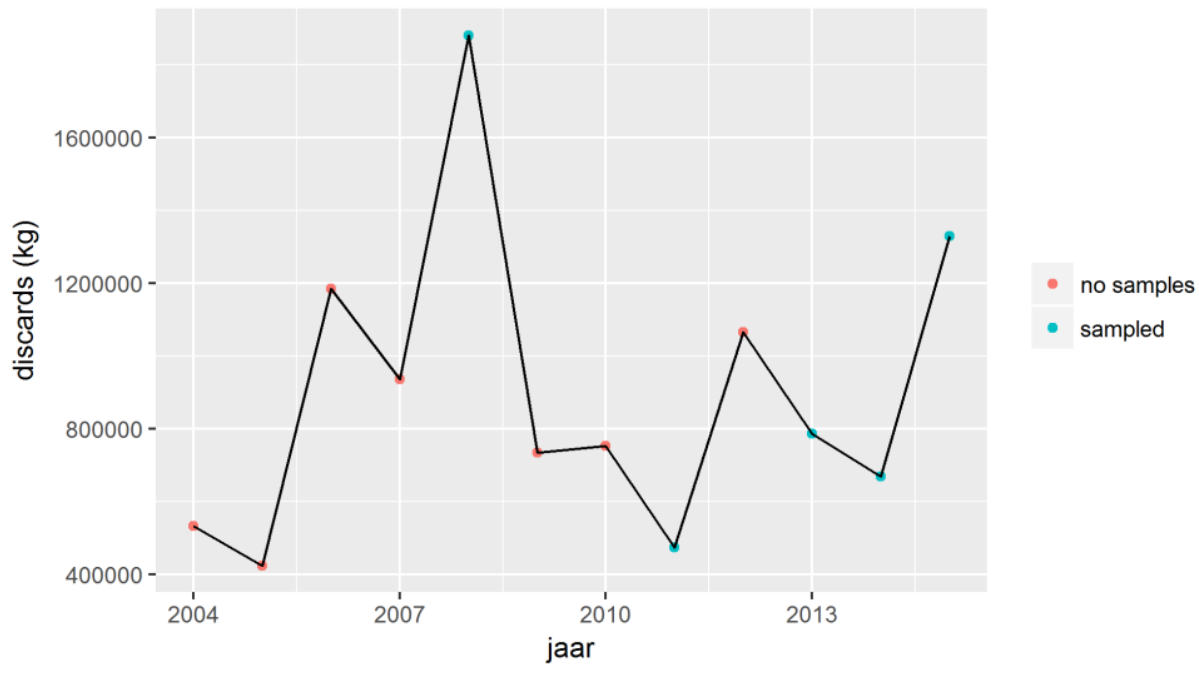

Figuur 0-38 Totale geschatte hoeveelheid garnaal- en visdiscards ( $\mathrm{kg}$ ) uit de garnalenvisserij over de periode 2004-2015. Rode punten geven de jaren waar geen monsters beschikbaar zijn. De gegevens uit de jaren met monsters (blauwe punten) zijn gebruikt om de discards voor de jaren zonder monsters op te werken. 


\subsubsection{Garnalenexperimenten}

\section{Garnalenexperiment PMR}

Voor de jaren 2010, 2011 en 2012 is een alternatieve bron van gegevens over de bijvangsten van garnalenvisserij beschikbaar, namelijk het garnalenexperiment dat is uitgevoerd in de Voordelta in verband met de instelling van het BBG (hoofdstuk 1.3.2 en Schellekens et al. 2014). Hierbij zijn zes opeenvolgende maanden (juni-november) zes proefvakken experimenteel bevist (zes keer achter elkaar, per maand). Uit deze gegevens zijn alle visvangsten met vissen $<=10 \mathrm{~cm}$ geselecteerd (met als aanname dat de grotere vissen geweerd worden door het gebruik van de zeeflap) en alleen de eerste twee trekken. Dit leidt tot het volgende beeld:

Voor maatse garnalen is een duidelijk seizoenspatroon in de maanden juni-november in de grootte van de vangst te zien, met grotere vangsten later in het seizoen (Tabel 0-15). Ook de commerciële garnalenvisserij vindt vooral in de maanden september, oktober en november plaats. Een belangrijk deel van de discards is ondermaatse garnaal (Tabel 0-15 en Tabel 0-16). Verder bestaan de discards voor een deel uit de vier meest aangelande platvissoorten, al is het aandeel t.o.v. het totaal aan andere vissen meestal laag. Het aandeel discards vertoont -in tegenstelling tot de vangst aan maatse garnaal- geen duidelijk seizoenspatroon in de maanden juni-november.

De vangst per visuur in het experiment is opgewerkt naar geschatte vangst in de hele garnalenvisserij in de Voordelta, door te vermenigvuldigen met het aantal visuren van de garnalenvloot. Hieruit volgt de schatting dat er 1000, 734, 1021 ton garnaal is aangeland in respectievelijk 2010-2012 (Figuur 0-39, Tabel 0-17). Dit komt redelijk goed overeen met de aanlandingen in de logboeken (1006, 812, 751, Appendix 2). Ook de schatting van de hoeveelheid discards komen redelijk goed overeen: 831, 434 en 901 ton garnaal in het garnalenexperiment en 645, 347 en 911 in het reguliere monitoringsprogramma. De totale discards zijn iets kleiner dan de totale vangst van maatse garnaal.

De gegevens van dit experiment ondersteunen dus de schattingen qua garnalendiscards zoals verkregen uit het reguliere monitoringprogramma.

Tabel 0-15 Gemiddelde vangst (ton) per uur vissen, voor de zes experimentele bevissingen uitgevoerd in $2010 \mathrm{t} / \mathrm{m} 2012$.

\begin{tabular}{|c|c|c|c|c|c|c|c|c|c|}
\hline jaar & $\begin{array}{c}\text { Week } \\
\text { nr }\end{array}$ & maand & $\begin{array}{l}\text { Garnaal } \\
>50 \mathrm{~mm}\end{array}$ & $\begin{array}{c}\text { Garnaal } \\
<=50 \mathrm{~mm}\end{array}$ & $\begin{array}{c}\text { Bot } \\
<=10 \mathrm{~cm}\end{array}$ & $\begin{array}{c}\text { Schar } \\
<=10 \mathrm{~cm}\end{array}$ & $\begin{array}{c}\text { Schol } \\
<=10 \mathrm{~cm}\end{array}$ & $\begin{array}{c}\text { Tong } \\
<=10 \mathrm{~cm}\end{array}$ & $\begin{array}{c}\text { Overig } \\
\text { (vis) } \\
<=10 \mathrm{~cm}\end{array}$ \\
\hline 2010 & 24 & 6 & 0.014 & 0.004 & 0.000 & 0.001 & 0.002 & 0.000 & 0.002 \\
\hline 2010 & 29 & 7 & 0.012 & 0.011 & 0.000 & 0.000 & 0.004 & 0.000 & 0.012 \\
\hline 2010 & 34 & 8 & 0.069 & 0.129 & 0.000 & 0.001 & 0.003 & 0.002 & 0.023 \\
\hline 2010 & 39 & 9 & 0.099 & 0.072 & 0.000 & 0.000 & 0.000 & 0.000 & 0.010 \\
\hline 2010 & 44 & 10 & 0.151 & 0.073 & 0.000 & 0.002 & 0.001 & 0.001 & 0.012 \\
\hline 2010 & 49 & 11 & 0.080 & 0.062 & 0.000 & 0.004 & 0.001 & 0.001 & 0.037 \\
\hline 2011 & 22 & 5 & 0.049 & 0.017 & 0.000 & 0.003 & 0.002 & 0.001 & 0.005 \\
\hline 2011 & 26 & 6 & 0.031 & 0.008 & 0.000 & 0.001 & 0.002 & 0.000 & 0.014 \\
\hline 2011 & 30 & 7 & 0.033 & 0.031 & 0.000 & 0.001 & 0.006 & 0.000 & 0.012 \\
\hline 2011 & 34 & 8 & 0.024 & 0.024 & 0.000 & 0.000 & 0.000 & 0.000 & 0.006 \\
\hline 2011 & 38 & 9 & 0.080 & 0.062 & 0.000 & 0.001 & 0.001 & 0.000 & 0.035 \\
\hline 2011 & 42 & 10 & 0.091 & 0.040 & 0.000 & 0.001 & 0.001 & 0.000 & 0.044 \\
\hline 2012 & 22 & 5 & 0.051 & 0.022 & 0.000 & 0.000 & 0.005 & 0.000 & 0.016 \\
\hline 2012 & 26 & 6 & 0.044 & 0.021 & 0.000 & 0.000 & 0.013 & 0.000 & 0.015 \\
\hline 2012 & 30 & 7 & 0.015 & 0.016 & 0.000 & 0.000 & 0.001 & 0.000 & 0.010 \\
\hline 2012 & 34 & 8 & 0.019 & 0.034 & 0.000 & 0.000 & 0.000 & 0.000 & 0.011 \\
\hline 2012 & 38 & 9 & 0.039 & 0.032 & 0.000 & 0.002 & 0.002 & 0.001 & 0.017 \\
\hline 2012 & 42 & 10 & 0.143 & 0.149 & 0.000 & 0.003 & 0.009 & 0.001 & 0.070 \\
\hline
\end{tabular}


Tabel 0-16. Verhouding tussen bijvangsten ten opzichte van maatse garnalenvangst, voor de zes experimentele bevissingen uitgevoerd in $2010 \mathrm{t} / \mathrm{m} 2012$.

\begin{tabular}{|c|c|c|c|c|c|c|c|c|}
\hline jaar & $\begin{array}{c}\text { Week } \\
\text { nr }\end{array}$ & maand & $\begin{array}{l}\text { Garnaal } \\
<=50 \mathrm{~mm}\end{array}$ & $\begin{array}{l}\text { Bot } \\
<=10 \mathrm{~cm}\end{array}$ & $\begin{array}{l}\text { Schar } \\
<=10 \mathrm{~cm}\end{array}$ & $\begin{array}{l}\text { Schol } \\
<=10 \mathrm{~cm}\end{array}$ & $\begin{array}{l}\text { Tong } \\
<=10 \mathrm{~cm}\end{array}$ & $\begin{array}{l}\text { Overig (vis) } \\
<=10 \mathrm{~cm}\end{array}$ \\
\hline 2010 & 24 & 6 & 0.29 & 0.00 & 0.06 & 0.13 & 0.00 & 0.18 \\
\hline 2010 & 29 & 7 & 0.98 & 0.00 & 0.00 & 0.32 & 0.00 & 1.07 \\
\hline 2010 & 34 & 8 & 1.86 & 0.00 & 0.01 & 0.05 & 0.02 & 0.33 \\
\hline 2010 & 39 & 9 & 0.73 & 0.00 & 0.00 & 0.00 & 0.00 & 0.10 \\
\hline 2010 & 44 & 10 & 0.49 & 0.00 & 0.01 & 0.01 & 0.00 & 0.08 \\
\hline 2010 & 49 & 11 & 0.78 & 0.00 & 0.05 & 0.01 & 0.01 & 0.46 \\
\hline 2011 & 22 & 5 & 0.34 & 0.00 & 0.06 & 0.04 & 0.03 & 0.10 \\
\hline 2011 & 26 & 6 & 0.25 & 0.00 & 0.02 & 0.08 & 0.00 & 0.46 \\
\hline 2011 & 30 & 7 & 0.95 & 0.00 & 0.02 & 0.19 & 0.01 & 0.35 \\
\hline 2011 & 34 & 8 & 1.04 & 0.00 & 0.01 & 0.01 & 0.00 & 0.24 \\
\hline 2011 & 38 & 9 & 0.77 & 0.00 & 0.01 & 0.02 & 0.00 & 0.44 \\
\hline 2011 & 42 & 10 & 0.44 & 0.00 & 0.01 & 0.02 & 0.00 & 0.48 \\
\hline 2012 & 22 & 5 & 0.43 & 0.00 & 0.00 & 0.09 & 0.01 & 0.32 \\
\hline 2012 & 26 & 6 & 0.48 & 0.00 & 0.01 & 0.31 & 0.00 & 0.33 \\
\hline 2012 & 30 & 7 & 1.09 & 0.00 & 0.01 & 0.09 & 0.00 & 0.68 \\
\hline 2012 & 34 & 8 & 1.78 & 0.00 & 0.01 & 0.02 & 0.02 & 0.57 \\
\hline 2012 & 38 & 9 & 0.82 & 0.00 & 0.04 & 0.04 & 0.04 & 0.45 \\
\hline 2012 & 42 & 10 & 1.04 & 0.00 & 0.02 & 0.06 & 0.00 & 0.49 \\
\hline
\end{tabular}
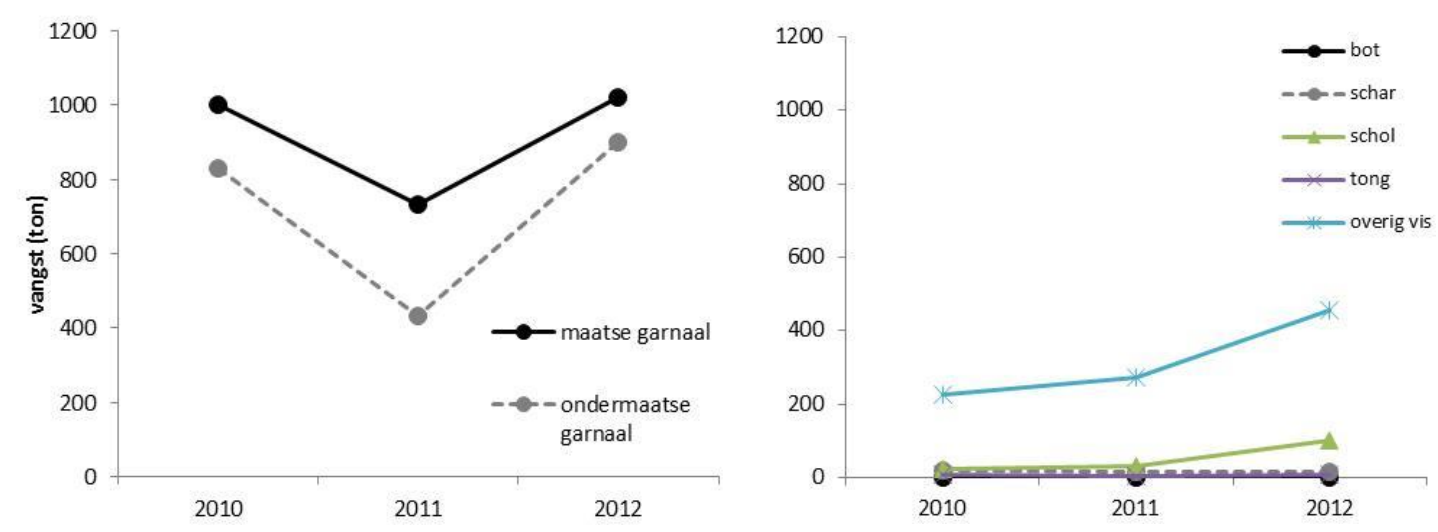

Figuur 0-39 Geschatte vangst (ton $=1000 \mathrm{~kg}$ ) aan maatse en ondermaatse garnaal (links) en vis $<=10 \mathrm{~cm}$ (rechts) van de garnalenkotters in de Voordelta, gebaseerd op vangstgegevens van het garnaalexperiment Voordelta en de logboekgegevens van de commerciële garnalenvloot.

Tabel 0-17 Geschatte vangst aan maatse en ondermaatse garnaal en vis $<=10 \mathrm{~cm}$ van de garnalenkotters in de Voordelta, gebaseerd op vangstgegevens van het garnaalexperiment Voordelta en de visuren uit de logboeken van de commerciële garnalenvloot.

\begin{tabular}{|ccccccccc|}
\hline & & & & & & & & \multicolumn{2}{l|}{$\begin{array}{l}\text { overig } \\
\text { (vis) }\end{array}$} \\
jaar & visuren & $\begin{array}{l}\text { garnaal } \\
>50 \mathrm{~mm}\end{array}$ & $\begin{array}{l}\text { garnaal } \\
<=50 \mathrm{~mm}\end{array}$ & $\begin{array}{l}\text { bot } \\
<=10 \mathrm{~cm}\end{array}$ & $\begin{array}{l}\text { schar } \\
<=10 \mathrm{~cm}\end{array}$ & $\begin{array}{l}\text { schol } \\
<=10 \mathrm{~cm}\end{array}$ & $\begin{array}{l}\text { tong } \\
<=10 \mathrm{~cm}\end{array}$ & $\begin{array}{l}<\mathrm{cm} \\
2010\end{array}$ \\
\hline 14158 & 1000 & 831 & 0.2 & 19 & 25 & 7 & 228 \\
2011 & 14268 & 734 & 434 & 0 & 15 & 32 & 5 & 274 \\
2012 & 19649 & 1021 & 901 & 0.2 & 16 & 101 & 9 & 457 \\
\hline
\end{tabular}




\section{Garnalendiscards in N2000-gebieden}

Voor de jaren 2012, 2013 en 2014 zijn gegevens over de seizoensvariatie in bijvangsten van garnalenvisserij beschikbaar uit de studie van garnalendiscards in N2000 gebieden, die onder andere ook in de Voordelta is uitgevoerd (Glorius et al. 2015). Over drie jaar heen is elk kwartaal de vangstsamenstelling van 8-17 trekken in de Voordelta van de commerciële garnalenvisserij door de bemanning zelf bemonsterd (Tabel $0-2$ ). Het geschatte vangstsucces per kwartaal van de vier meest aangelande vissoorten (schol, tong, schar en bot) en de maatse garnaal wordt hier als schatting voor het gemiddelde vangstsucces per kwartaal voor de jaren 2012-2014 genomen. Een schatting van de totale visbiomassa en de ondermaatse garnaal kan door de gebruikte proefopzet niet gemaakt worden (zie hoofdstuk 1.3.2).

Het vangstsucces van maatse garnaal loopt sterk op door het jaar heen. De hoeveelheid gediscarde vis toont ook seizoensvariatie. Het vangstsucces van gediscarde bot is hoog in het eerste kwartaal, maar deze soort wordt bijna niet gevangen in de overige kwartalen (Figuur 0-40). Schar wordt met name in de winterhelft (kwartaal 1 en 4) gediscard en schol in kwartalen 1, 3 en 4. Tong is in alle kwartalen nauwelijks gevangen in de bemonsterde reizen. De discards van deze vier soorten opgeteld in het eerste kwartaal verhouden zich $53 \%$ van de garnaalaanlandingen in deze visserij. In de overige kwartalen zijn de discards van deze soorten veel lager: 5-11\%. Dit komt doordat de garnaalaanlandingen toenemen door het jaar heen en doordat de discards in het eerste kwartaal het hoogst zijn.

Gemiddeld over alle kwartalen heen zijn de discards van deze vier soorten $19 \%$ van de garnaalaanlandingen. Dit komt grofweg overeen met het aandeel zoals berekend in het garnalenexperiment van PMR in 2012 (12\%).
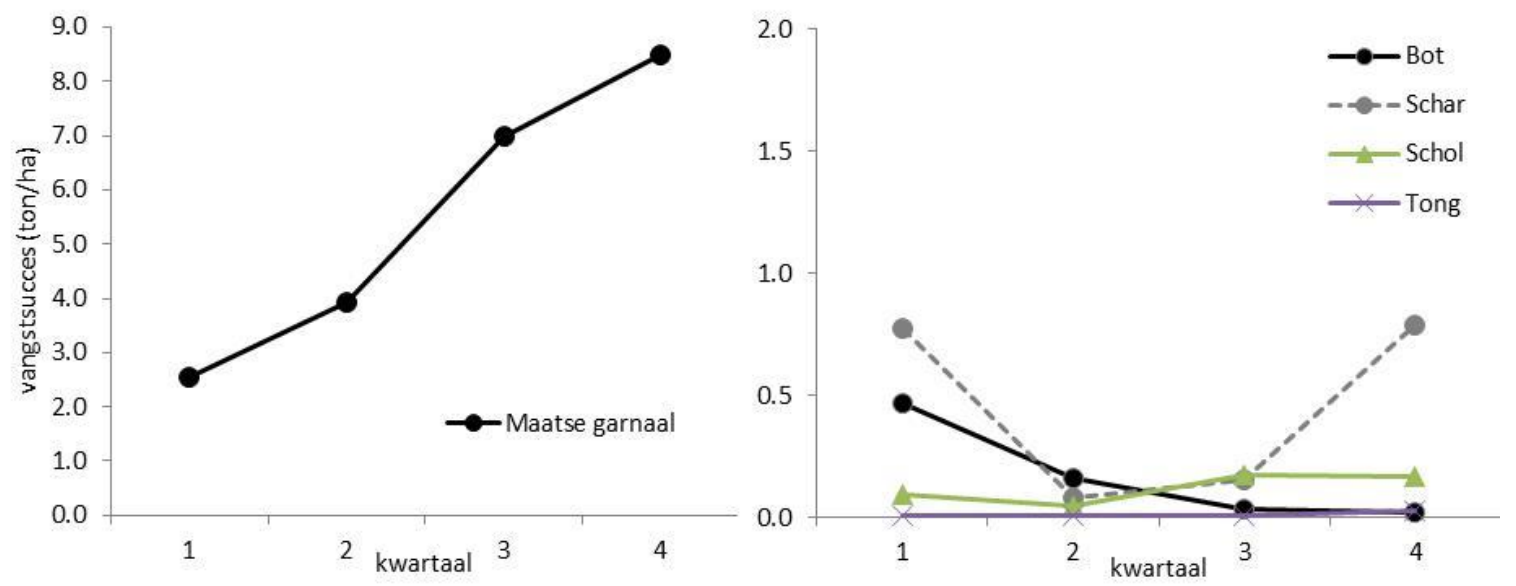

Figuur 0-40 Geschatte commercieel vangstsucces (ton per hectare) aan maatse garnaal (links) en vis (rechts) van de garnalenkotters in de Voordelta, gebaseerd op vangstgegevens uit de Voordelta van de garnaaldiscardstudie in N2000 gebieden.

\section{Conclusie aanvullende garnalenexperimenten}

De discardschattingen voor garnaal (hoofdstuk 5.2.1) zijn met grote aannames gemaakt en hebben daardoor grote onzekerheidsmarges. Dit geldt zowel voor absolute schattingen per jaar (omdat er weinig/geen bemonsteringslocaties in de Voordelta waren) als voor de trend door de tijd heen (omdat voor veel jaar helemaal geen data beschikbaar was). Echter, de aanvullende gegevens vanuit de twee garnalenexperimenten ondersteunen in grove lijn de schattingen uit de reguliere monitoringsprogramma's, voor de jaren waarin deze experimenten plaatsvonden. 


\section{Impact van visserij-onttrekking op de commerciële bestanden}

In dit hoofdstuk wordt de impact van de onttrekking van vis en benthos door de visserij (aanlandingen en discards) op de bestanden geëvalueerd: Het ecologische effect van visserij-onttrekking is niet alleen afhankelijk van de hoeveelheid vis en benthos die onttrokken wordt, maar ook van de grootte van het bestand. Als bijvoorbeeld de hoeveelheid onttrokken vis toeneemt door de jaren, maar de hoeveelheid vis in het bestand veel sterker toeneemt, dan is het effect op het bestand juist gedaald.

Garnaal is de belangrijkste onttrokken soort in de garnalenvisserij; deze soort is $93 \%$ van de hoeveelheid aanlandingen en $87 \%$ van de discards in de garnalenvisserij. Schol, schar, bot en tong zijn de vier belangrijkste aangelande soorten van de platviskotters; ze zijn samen $94 \%$ van de hoeveelheid aanlandingen. De impact van de boomkorvisserij op de bestanden van deze soorten zal dus worden besproken hier. Daarnaast worden ook andere bestanden bekeken die veel gediscard worden in de Voordelta (zie hoofdstuk 5, tabel 5.1). Voor een aantal van de bestanden die samen $95 \%$ van de totale hoeveelheid discards maken, kan de impact van de visserij ook onderzocht worden; wijting, tongschar, zandspiering en griet (hoofdstuk 6.1.6).

Voor het schatten van de impact zijn schattingen van de bestandsgrootte nodig. Er is gewerkt met de modeluitkomsten die ICES publiceert, waarin alle relevante informatie uit wetenschappelijke surveys en commerciële visserijgegevens zijn gebruikt om een schatting te geven van de bestandsgrootte. Bij voorkeur wordt de visserij-inspanning afgezet tegen de totale biomassa in de Voordelta. Voor garnaal zijn hiervoor schattingen beschikbaar (op basis van modellen ontwikkeld voor de Noordzee (ICES 2015c; Tulp et al. 2016). Echter, voor de visbestanden is hier geen informatie voor beschikbaar. Er is alleen een bestandsschatting beschikbaar op Noordzee-schaal of hoger, omdat de relevante bestanden op deze schaal leven.

\subsection{Schol}

De schol die gevangen wordt in de Voordelta is onderdeel van het bestand van de Noordzee/Skagerrak. Voor dit bestand wordt door ICES per jaar een bestandsschatting gemaakt (ICES 2017). Het scholbestand is in zeer goede staat en is de laatste tien jaar steeds groter geworden (Figuur 0-41). De visserijsterfte ligt al jaren rond streefwaarde $\mathrm{F}_{\mathrm{MSY}}{ }^{13}$. Dit is de waarde van visserijsterfte waarbij in theorie duurzame maximale vangsten gewaarborgd zijn.

Het belang van de Nederlandse boomkorkotters in de Voordelta ten opzichte van de gehele visserij in de Noordzee is zeer klein: $0.016-0.69 \%$ van alle onttrekkingen zijn voor rekening van de vangsten van de boomkorkotters in de Voordelta (Tabel 0-18). Het deel van het scholbestand dat wordt onttrokken in de Voordelta door de Nederlandse boomkorkotters is ook zeer klein; $0.002-0.022 \%$. Dit aandeel is ook sterk gedaald door de jaren heen (Figuur 0-41), wat verklaard kan worden door zowel een toename in totale biomassa (Figuur 0-41) en een afname in aanlandingen in de Voordelta (Figuur $0-25)$. Overigens daalt ook het aandeel van het paaibestand dat door de gehele internationale vloot wordt aangeland in de gehele Noordzee, maar het aandeel gevangen door de Nederlandse boomkorkotters in de Voordelta daalt hierbij nog sterker (rechterkolom in Tabel 0-18).

\footnotetext{
${ }^{13}$ MSY staat voor Maximum Sustainable Yield, een Europese doelstelling waarin voorzien wordt dat op de lange termijn een maximale duurzame oogst gerealiseerd kan worden zolang er met een maximale visserij ter hoogte van $F_{\text {msy }}$ gevist wordt
} 


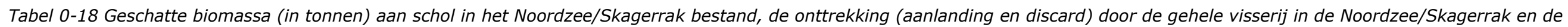

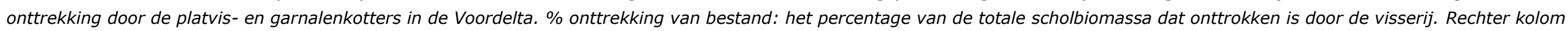

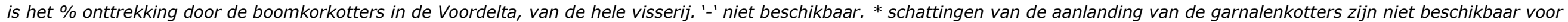
2004 en 2005 maar gezien de lage schattingen in de jaren erna, worden deze aangenomen verwaarloosbaar te zijn.

\begin{tabular}{|c|c|c|c|c|c|c|c|c|c|c|c|}
\hline jaar & $\begin{array}{l}\text { scholbe } \\
\mathrm{NZ} /\end{array}$ & $\begin{array}{c}\text { totaal } \\
\text { bestand }\end{array}$ & aanlanding & $\begin{array}{l}\text { NZle visse } \\
\text { discards }\end{array}$ & $\begin{array}{c}\% \\
\text { onttrekking } \\
\text { van } \\
\text { bestand } \\
\end{array}$ & $\begin{array}{c}\text { aanlanding } \\
\text { platviskotters }\end{array}$ & $\begin{array}{c}\text { boomkorkotters } \\
\text { aanlanding } \\
\text { garnalenkotters }\end{array}$ & $\begin{array}{l}\text { n de Voordelta } \\
\text { discards } \\
\text { platviskotters }\end{array}$ & $\begin{array}{c}\text { discards } \\
\text { garnalenkotters }\end{array}$ & $\begin{array}{l}\% \text { onttrekking } \\
\text { van bestand* }\end{array}$ & $\begin{array}{l}\text { \% onttrekking door } \\
\text { boomkorkotters in } \\
\text { de Voordelta, van } \\
\text { totale onttrekking* }\end{array}$ \\
\hline 2000 & 256904 & 376107 & 90754 & 44311 & 35.9 & & & & & & - \\
\hline 2001 & 303421 & 433576 & 92912 & 100309 & 44.6 & & & & & & - \\
\hline 2003 & 261400 & 400477 & 74722 & 79275 & 38.5 & & & & & & - \\
\hline 2004 & 242136 & 404951 & 70511 & 57478 & 31.6 & 62 & - & 16 & 11 & 0.022 & 0.069 \\
\hline 2005 & 284394 & 405889 & 62796 & 56250 & 29.3 & 25 & - & 10 & 8 & 0.011 & 0.036 \\
\hline 2006 & 295586 & 443890 & 67143 & 64160 & 29.6 & 25 & 0.1 & 7 & 24 & 0.013 & 0.042 \\
\hline 2007 & 300157 & 425243 & 58576 & 42373 & 23.7 & 13 & 0.0 & 7 & 19 & 0.009 & 0.038 \\
\hline 2008 & 391203 & 535632 & 58336 & 46993 & 19.7 & 11 & 0.1 & 5 & 44 & 0.011 & 0.057 \\
\hline 2009 & 431357 & 596422 & 62360 & 45902 & 18.2 & 11 & 0.0 & 4 & 15 & 0.005 & 0.027 \\
\hline 2010 & 523991 & 699784 & 70340 & 46570 & 16.7 & 11 & 0.1 & 2 & 15 & 0.004 & 0.024 \\
\hline 2012 & 555199 & 756780 & 82018 & 59914 & 18.8 & 15 & 0.1 & 3 & 21 & 0.005 & 0.028 \\
\hline 2013 & 619281 & 837073 & 86222 & 40025 & 15.1 & 11 & 1.0 & 4 & 16 & 0.004 & 0.025 \\
\hline 2014 & 774978 & 1006750 & 80686 & 52937 & 13.3 & 7 & 0.5 & 2 & 12 & 0.002 & 0.016 \\
\hline 2015 & 754812 & 896659 & 85360 & 49100 & 15.0 & 10 & 0.8 & 2 & 28 & 0.005 & 0.031 \\
\hline
\end{tabular}



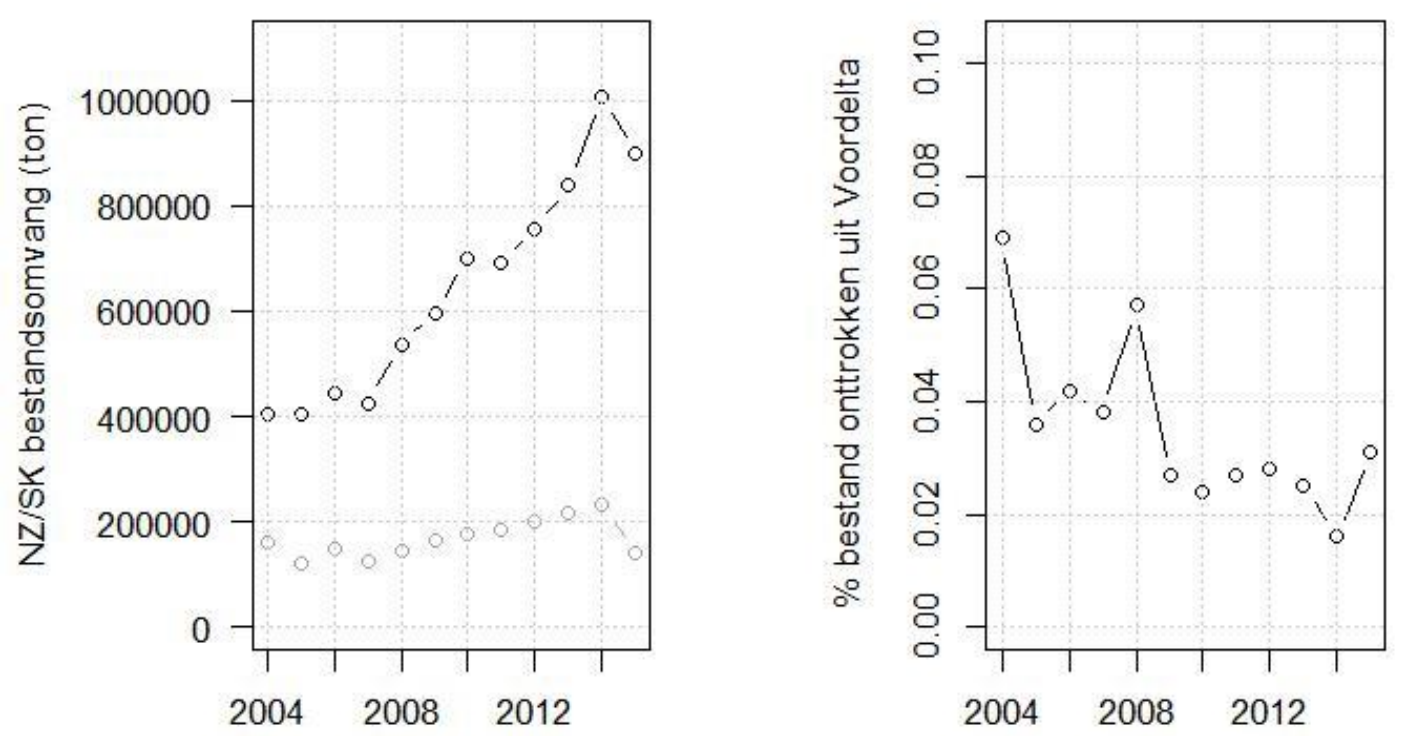

Figuur 0-41. Bestandsomvang van schol (gehele bestand in zwart, juveniel bestand in grijs) in Noordzee/Skagerrak (links) en percentage van het bestand dat onttrokken door de Nederlandse boomkorkotters in de Voordelta (rechts).

\subsection{Tong}

De tong die gevangen wordt door de boomkorkotters in de Voordelta is onderdeel van het bestand van de Noordzee. Voor dit bestand wordt door ICES per jaar een bestandsschatting gemaakt. Het tongbestand is in goede staat en groeit sinds tien jaar (Figuur 0-42Fout! Verwijzingsbron niet gevonden.). De visserijsterfte is te hoog en ligt iets hoger dan $F_{\text {msy }}$ (ICES 2015c).

Het belang van de Nederlandse boomkorkotters in de Voordelta ten opzichte van de gehele visserij in de Noordzee is zeer klein: minder dan $1 \%$ van alle onttrekkingen zijn voor rekening van de vangsten van de boomkorkotters in de Voordelta (Tabel 0-19). Het deel van het tongbestand dat wordt onttrokken in de Voordelta door de Nederlandse boomkorkotters is ook zeer klein: in $20150.08 \%$. Het aandeel is sterk gedaald door de jaren heen (Figuur 0-42), wat verklaard kan worden door zowel een toename in totale bestandsbiomassa en een afname in aanlandingen in de Voordelta (ICES 2015c). Overigens daalt ook het aandeel van het paaibestand dat door de gehele internationale vloot wordt aangeland in de gehele Noordzee, maar het aandeel gevangen door de Nederlandse boomkorkotters in de Voordelta daalt hierbij nog sterker (rechterkolom in Tabel 0-19). 


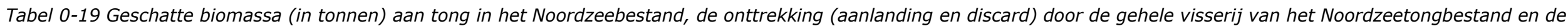

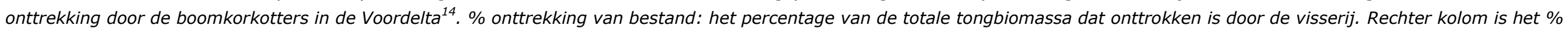

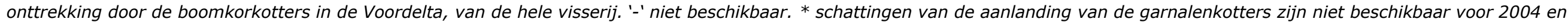
2005 maar gezien de lage schattingen in de jaren erna, worden deze aangenomen verwaarloosbaar te zijn.

\begin{tabular}{|c|c|c|c|c|c|c|c|c|c|c|c|}
\hline jaar & $\begin{array}{l}\text { tongbes } \\
\text { Noord }\end{array}$ & $\begin{array}{l}\text { totaal } \\
\text { bestand }\end{array}$ & aanlanding & $\begin{array}{l}\text { ehele visse } \\
\text { Noordzee } \\
\text { discards }\end{array}$ & $\begin{array}{l}\text { ij } \\
\text { \% } \\
\text { onttrekking } \\
\text { van } \\
\text { bestand }\end{array}$ & $\begin{array}{c}\text { aanlanding } \\
\text { platviskotters }\end{array}$ & $\begin{array}{c}\text { boomkorkotter } \\
\text { aanlanding } \\
\text { garnalenkotters }\end{array}$ & $\begin{array}{c}\text { discards } \\
\text { platviskotters }\end{array}$ & $\begin{array}{c}\text { discards } \\
\text { garnalenkotters }\end{array}$ & $\begin{array}{l}\% \text { onttrekking } \\
\text { van bestand* }\end{array}$ & $\begin{array}{c}\% \text { onttrekking } \\
\text { door } \\
\text { boomkorkotters } \\
\text { in de Voordelta, } \\
\text { van totale } \\
\text { onttrekking* }\end{array}$ \\
\hline 2000 & 40595 & 62031 & 20461 & 2610 & 37.2 & & & & & & - \\
\hline 2001 & 34640 & 56205 & 18453 & 2247 & 36.8 & & & & & & - \\
\hline 2002 & 35489 & 55650 & 16617 & 1817 & 33.1 & & & & & & - \\
\hline 2003 & 27520 & 60187 & 16691 & 3007 & 32.7 & & & & & & - \\
\hline 2004 & 39574 & 53541 & 17420 & 2800 & 37.8 & 152 & - & 6.2 & 2.4 & 0.30 & 0.80 \\
\hline 2005 & 31191 & 40504 & 12936 & 1535 & 35.7 & 68 & - & 3.8 & 1.9 & 0.18 & 0.51 \\
\hline 2006 & 25213 & 41186 & 10577 & 1078 & 28.3 & 54 & 0.8 & 2.6 & 5.4 & 0.15 & 0.53 \\
\hline 2007 & 18415 & 47043 & 9460 & 1576 & 23.5 & 75 & 1.3 & 2.7 & 4.3 & 0.18 & 0.76 \\
\hline 2008 & 36219 & 49634 & 13352 & 1836 & 30.6 & 61 & 1.7 & 1.9 & 14.6 & 0.16 & 0.52 \\
\hline 2009 & 31630 & 46688 & 12399 & 1480 & 29.7 & 33 & 0.4 & 1.5 & 3.4 & 0.08 & 0.28 \\
\hline 2011 & 30767 & 68979 & 11997 & 2015 & 20.3 & 34 & 0.5 & 1.0 & 0.5 & 0.05 & 0.26 \\
\hline 2012 & 38452 & 51574 & 14339 & 2147 & 32.0 & 34 & 0.9 & 1.2 & 4.9 & 0.08 & 0.25 \\
\hline 2013 & 48012 & 56033 & 15059 & 1602 & 29.7 & 49 & 0.6 & 2.3 & 2.0 & 0.10 & 0.32 \\
\hline 2014 & 45163 & 59678 & 13302 & 1398 & 24.6 & 26 & 1 & 0.4 & 3.8 & 0.05 & 0.21 \\
\hline 2015 & 49142 & 78372 & 12630 & 1663 & 18.2 & 52 & 6 & 1.1 & 0.8 & 0.08 & 0.42 \\
\hline
\end{tabular}

| 58 van 106 | Wageningen Marine Research rapport C105/17 

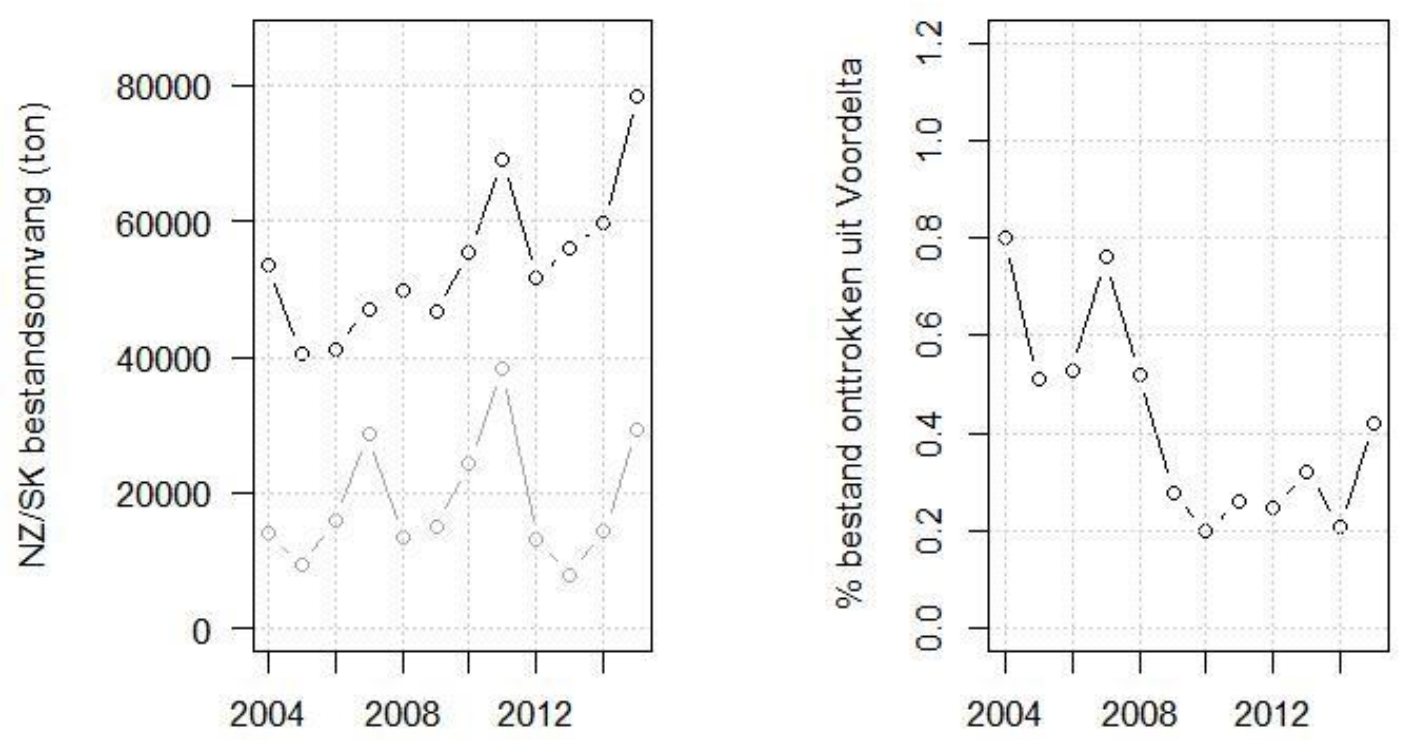

Figuur 0-42. Bestandsomvang van tong (gehele bestand in zwart, juveniel bestand in grijs) in Noordzee/Skagerrak (links) en percentage van het bestand dat onttrokken wordt door de Nederlandse platviskotters in de Voordelta (rechts)

\subsection{Bot}

De bot die gevangen wordt door de boomkorkotters in de Voordelta is onderdeel van het bestand van de Noordzee, het Skagerrak en het Kattegat. Voor dit bestand wordt door ICES geen bestandsschatting gemaakt en zijn geen tijdreeksen over de hoeveelheid discards beschikbaar. Wel wordt naar relatieve veranderingen in een index van de bestandsgrootte gekeken en zijn gegevens over de aanlandingen beschikbaar (ICES 2015b).

Voor dit bestand kan dus niet zoals bij schol en tong direct gekeken worden naar bestandsomvang en het percentage onttrekking uit het bestand, maar alleen naar trends in bestandsomvang en hoe de trend in onttrekking daaraan relateert.

Het botbestand vertoont veel fluctuatie maar geen duidelijke trend in bestandsomvang, met een toename in 2005 en een afname in 2012-2015 (Tabel 0-20, Figuur 0-43). De hoeveelheid bot die wordt aangeland vanuit de Voordelta door de Nederlandse boomkorkotters is afgenomen door de jaren heen (Tabel 0-20). Ook daalt het aandeel van de totale aanlandingen door de boomkorkotters in de Voordelta (Tabel 0-20, Figuur 0-43). 


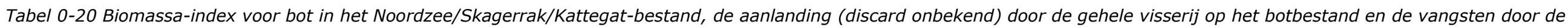

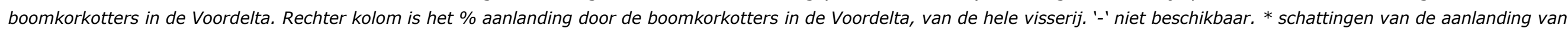
de garnalenkotters zijn niet beschikbaar voor 2004 en 2005 en gezien de hoge schattingen in de jaren erna, wordt het percentage aanlanding pas vanaf 2006 berekend.

\begin{tabular}{|c|c|c|c|c|c|c|c|}
\hline \multirow[b]{2}{*}{ jaar } & \multirow{2}{*}{$\begin{array}{l}\text { botbestand } \\
\mathrm{NZ/SK/KG} \\
\text { biomassa- } \\
\text { index }\end{array}$} & \multirow{2}{*}{$\begin{array}{c}\text { gehele visserij } \\
\text { NZ/SK/KG } \\
\text { aanlanding }\end{array}$} & \multicolumn{4}{|c|}{ boomkorkotters in de Voordelta } & \multirow{2}{*}{$\begin{array}{c}\% \text { aanlanding door } \\
\text { boomkorkotters in de Voordelta, } \\
\text { van totale aanlanding* }\end{array}$} \\
\hline & & & $\begin{array}{l}\text { aanlanding } \\
\text { platviskotters }\end{array}$ & $\begin{array}{c}\text { aanlanding } \\
\text { garnalenkotters }\end{array}$ & $\begin{array}{c}\text { discards } \\
\text { platviskotters }\end{array}$ & $\begin{array}{c}\text { discards } \\
\text { garnalenkotters }\end{array}$ & \\
\hline 2000 & 3.09 & 3821 & & & & & - \\
\hline 2001 & 2.74 & 3727 & & & & & - \\
\hline 2002 & 1.9 & 4414 & & & & & - \\
\hline 2003 & 2.76 & 4110 & & & & & - \\
\hline 2004 & 2.87 & 4772 & 340 & - & 5.9 & 0.7 & - \\
\hline 2005 & 4.91 & 4428 & 193 & - & 3.6 & 0.5 & - \\
\hline 2006 & 3.94 & 5007 & 107 & 32 & 2.5 & 1.5 & 2.86 \\
\hline 2007 & 4.28 & 4067 & 73 & 23 & 2.5 & 1.2 & 2.45 \\
\hline 2008 & 4.86 & 3241 & 71 & 25 & 1.8 & 1.1 & 3.04 \\
\hline 2009 & 3.95 & 3089 & 65 & 24 & 1.4 & 0.9 & 2.98 \\
\hline 2010 & 4.84 & 3364 & 42 & 21 & 0.8 & 1.0 & 1.92 \\
\hline 2011 & 3.89 & 3191 & 65 & 19 & 1.5 & 0.0 & 2.68 \\
\hline 2012 & 2.97 & 2305 & 34 & 11 & 0.7 & 1.4 & 2.04 \\
\hline 2013 & 3.17 & 1875 & 35 & 6 & 1.1 & 0.0 & 2.26 \\
\hline 2014 & 2.44 & 2062 & 17 & 8 & 0.3 & 0.0 & 1.22 \\
\hline 2015 & 3.66 & - & 51 & 12 & 2.0 & 2.0 & - \\
\hline
\end{tabular}



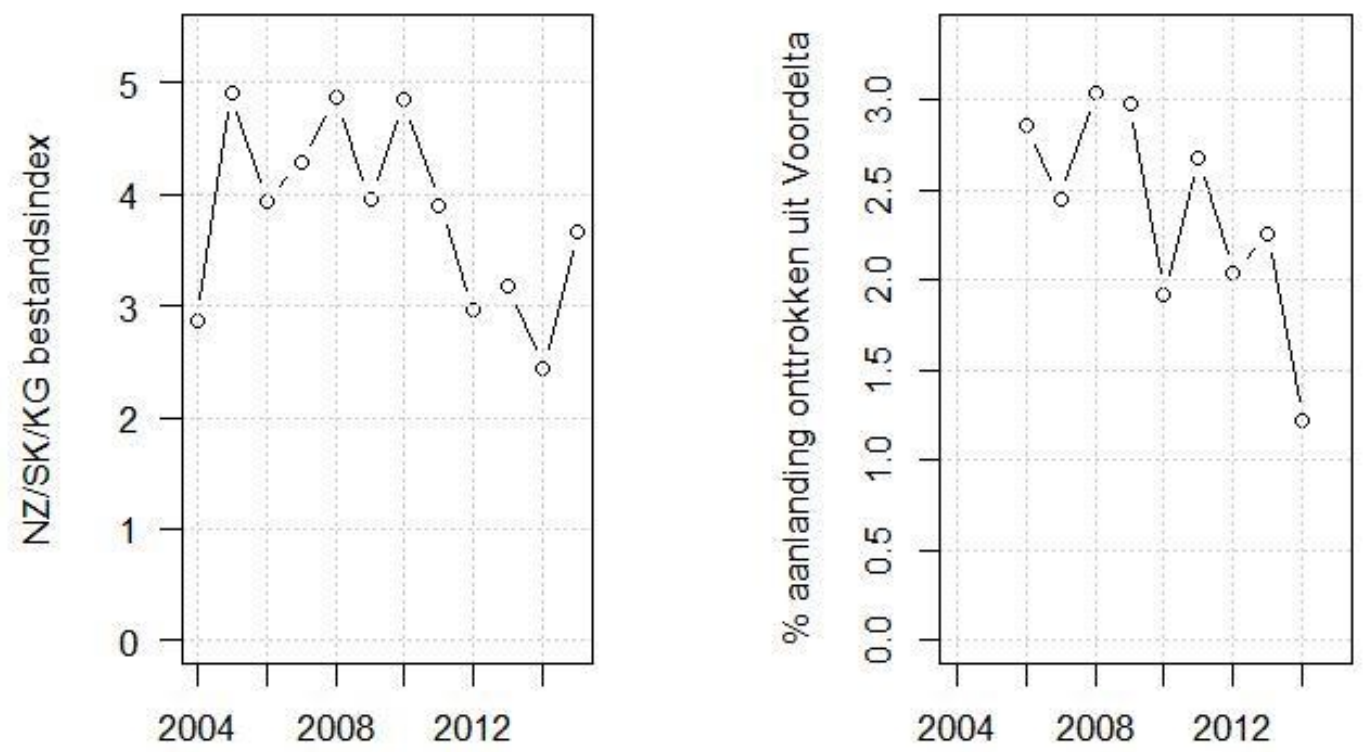

Figuur 0-43. Bestandsindex van bot in Noordzee/Skagerrak/Kattegat (links) en percentage aanlanding (van de totale Noordzeebrede aanlanding) van de Nederlandse boomkorkotters in de Voordelta (rechts)

\subsection{Schar}

De schar die gevangen wordt door de boomkorkotters in de Voordelta is onderdeel van het bestand van de Noordzee, het Skagerrak en het Kattegat. Voor dit bestand kan momenteel geen bestandsschatting gemaakt worden en er zijn geen tijdreeksen in de hoeveelheid discards beschikbaar. Er wordt door ICES naar relatieve veranderingen in een index van de bestandsgrootte gekeken en er zijn gegevens over de aanlandingen beschikbaar (ICES 2015a). Ook is voor 2012-2014 bekend dat de hoeveelheid discards een factor 6-12 hoger ligt dan de hoeveelheid aanlandingen. Voor dit bestand kan dus niet zoals bij schol en tong direct gekeken worden naar bestandsomvang en het percentage onttrekking uit het bestand, maar alleen naar trends in bestandsomvang en hoe de trend in aanlanding daaraan relateert.

Het scharbestand vertoont geen duidelijke trend in bestandsomvang (Tabel 0-21 en Figuur 0-44), terwijl de aanlandingen vanuit het gehele bestand sterk afnemen door de jaren (Tabel 0-21). De hoeveelheid schar die wordt aangeland vanuit de Voordelta door de Nederlandse boomkorkotters vertoont ook geen duidelijke trend (Tabel 0-21). Het aandeel van de totale scharaanlandingen dat de Nederlandse boomkorkotters in de Voordelta voor rekening nemen vertoont dus ook geen duidelijke trend (Tabel 0-21, Figuur 0-44).

Echter, de onttrekking van schar zal waarschijnlijk voornamelijk voor rekening van de discards komen, aangezien deze Noordzeebreed een factor 6-12 hoger liggen dan de aanlandingen. 


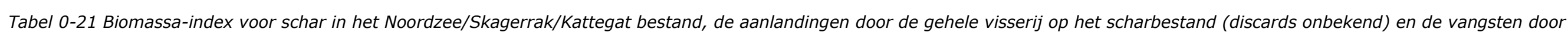

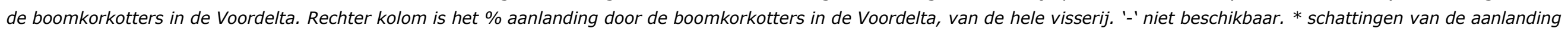
van de garnalenkotters zijn niet beschikbaar voor 2004 en 2005 en gezien de hoge schattingen in de jaren erna, wordt het percentage aanlanding pas vanaf 2006 berekend.

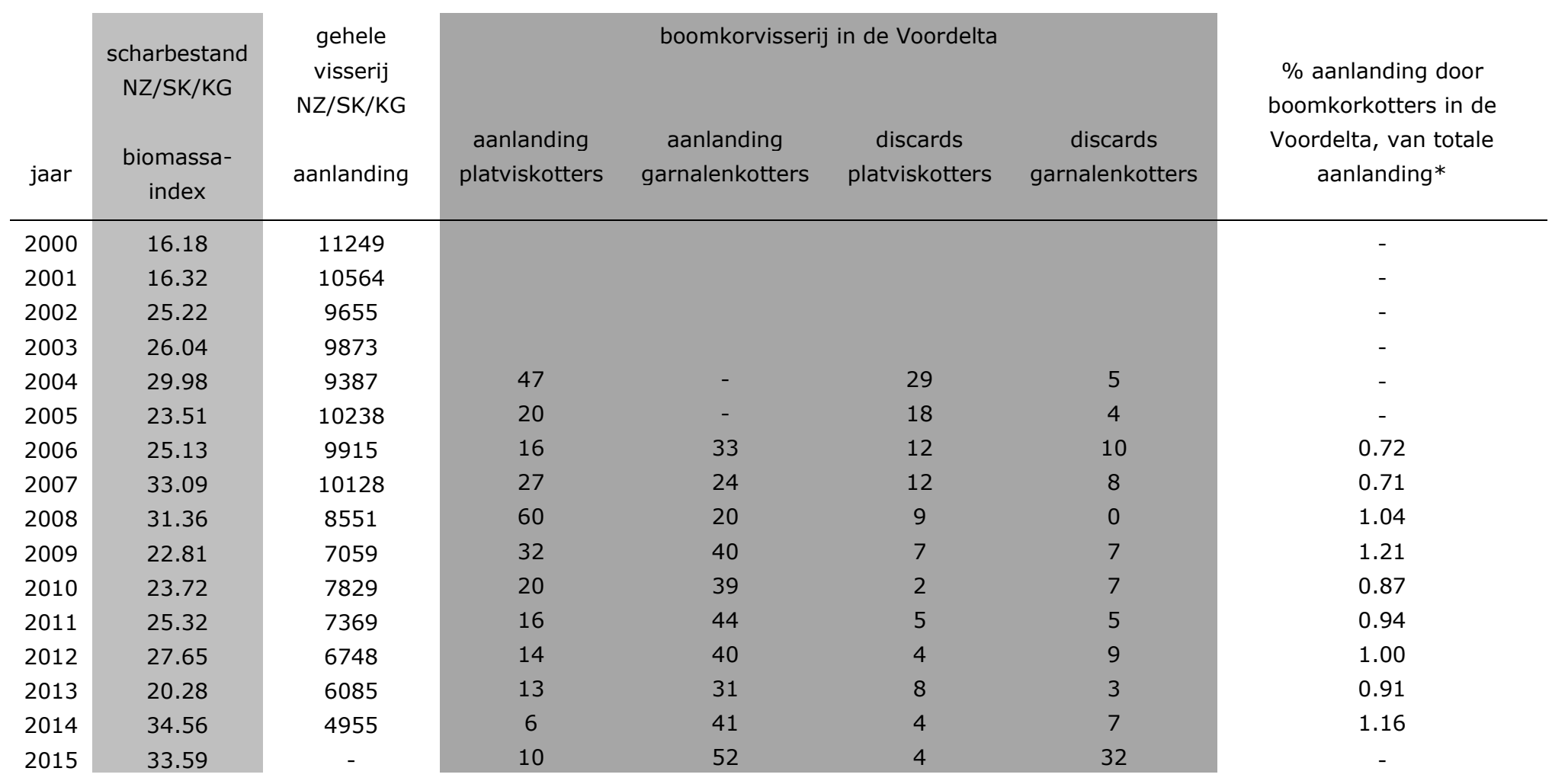



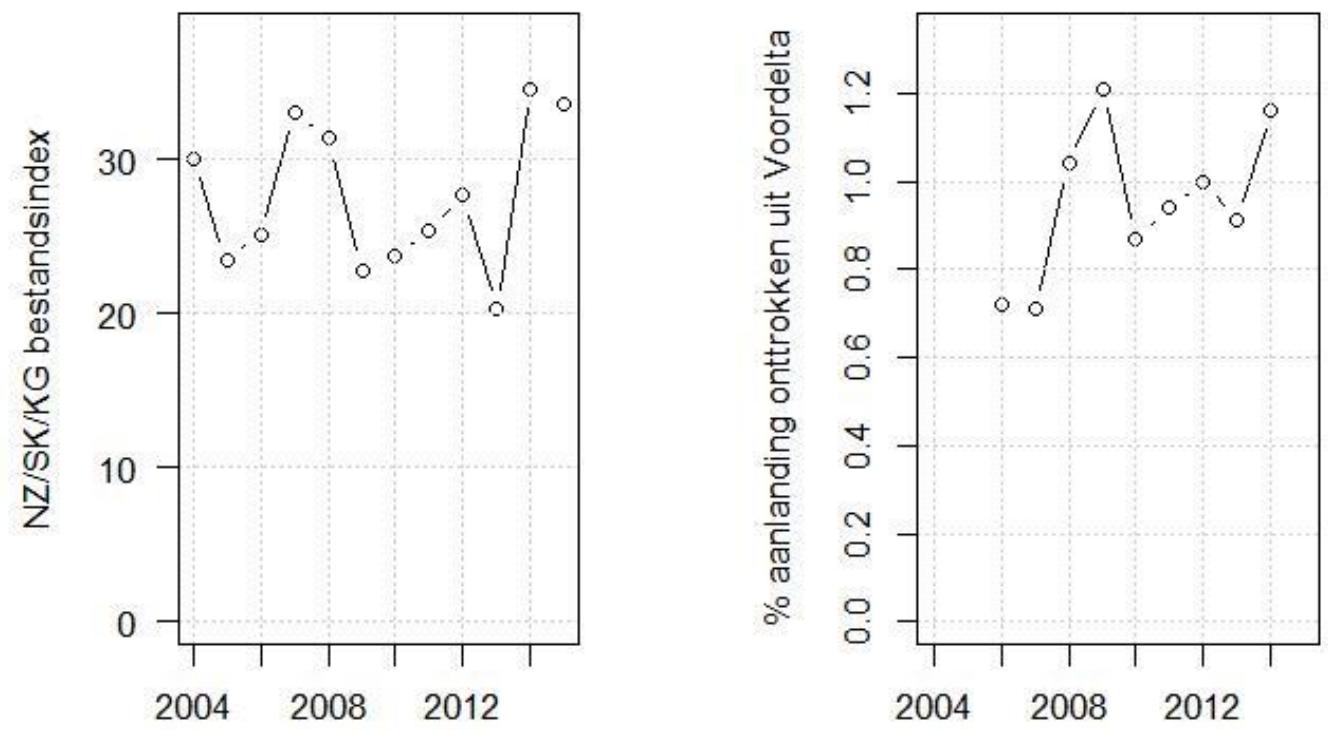

Figuur 0-44. Bestandsindex van schar in Noordzee/Skagerrak/Kattegat (links) en percentage aanlanding (van de totale Noordzeebrede aanlanding) van de Nederlandse boomkorkotters in de Voordelta (rechts)

\subsection{Garnaal}

Garnaalaanlandingen nemen al decennialang toe, terwijl de hoeveelheid garnaal in de Noordzee niet verandert. De visserijsterfte neemt daarom ook toe Noordzeebreed. Garnaal heeft markant andere populatiedynamica dan vis; er is geen duidelijke leeftijdsstructuur en reproductie vindt jaarrond plaats. Daarom zijn voor dit bestand andere modellen ontwikkeld, waarbij de jaarlijkse productie aan garnaal ( $>=50 \mathrm{~mm}$ ) wordt berekend met als basis het vangstsucces in de DFS-survey (ICES 2015c; Tulp et al. 2016). Met deze modellen kunnen ook voor de deelgebieden van de DFS-survey productieschattingen gemaakt worden. Gezien de relatief kleine ruimtelijke schaal van het leefgebied van garnaal levert dit waarschijnlijk ook biologisch gezien een realistische schatting van de lokale productie op. DFS-gebied 401 omvat de gehele Voordelta (Figuur 0-45). Voor dit gebied is daarom de jaarlijkse productie aan garnaal $(>=50 \mathrm{~mm}$ ) geschat, als proxy voor de hoeveelheid garnaal in de Voordelta.

De productie in DFS-deelgebied 401 kan sterk verschillen van jaar op jaar. Wel lijkt de productie toe te nemen over de periode 2006-2015. De garnalenkotters landen de garnalen vanaf grofweg 50mm lengte aan. Voor het schatten van de onttrekking vanuit de productie aan $>=50 \mathrm{~mm}$ garnaal kan dus gerekend worden met de aanlandingen (en de discards kunnen buiten beschouwing worden gelaten). Het aandeel van de jaarlijkse garnaalproductie in DFS-gebied 401 dat wordt onttrokken als aanlanding vanuit de Voordelta door de Nederlandse garnaalkotters is groot: in $201517.8 \%$ ( 
Tabel 0-22 en Figuur 0-46). Ook dit percentage onttrekking verschilt sterk van jaar op jaar.

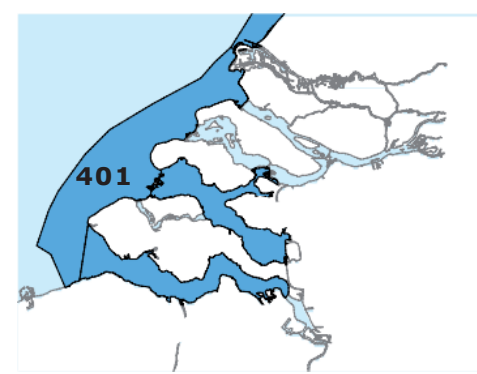

Figuur 0-45 DFS-deelgebied 401, voor de kust van Zeeland en Zuid-Holland. 
Tabel 0-22 Geschatte biomassaproductie per jaar (in tonnen) aan garnaal (>=50mm) in DFS-gebied 401, de onttrekking door de garnalenvisserij in de Voordelta en \% onttrekking van het bestand (>= 50mm): het percentage van de jaarlijkse productie aan garnaal $(>=50 \mathrm{~mm})$ in de Voordelta dat onttrokken is als aanlanding door de garnalenkotters.

\begin{tabular}{ccccc} 
garnaalproductie in DFS-401 & \multicolumn{3}{c}{ garnaalkotters in Voordelta } \\
jaar & biomassa (> 50mm) & aanlanding & discards & $\begin{array}{c}\text { ontrekking } \\
\text { van productie >=50mm }\end{array}$ \\
\hline 2006 & 8121 & 1018 & 1014 & 12.5 \\
2007 & 4163 & 578 & 801 & 13.9 \\
2008 & 6135 & 982 & 1781 & 16.0 \\
2009 & 7927 & 863 & 628 & 10.9 \\
2010 & 11029 & 1006 & 645 & 9.1 \\
2011 & 8414 & 812 & 347 & 9.7 \\
2012 & 7907 & 751 & 911 & 9.5 \\
2013 & 13403 & 880 & 732 & 6.6 \\
2014 & 9604 & 1818 & 512 & 18.9 \\
2015 & 7894 & 1406 & 1079 & 17.8
\end{tabular}
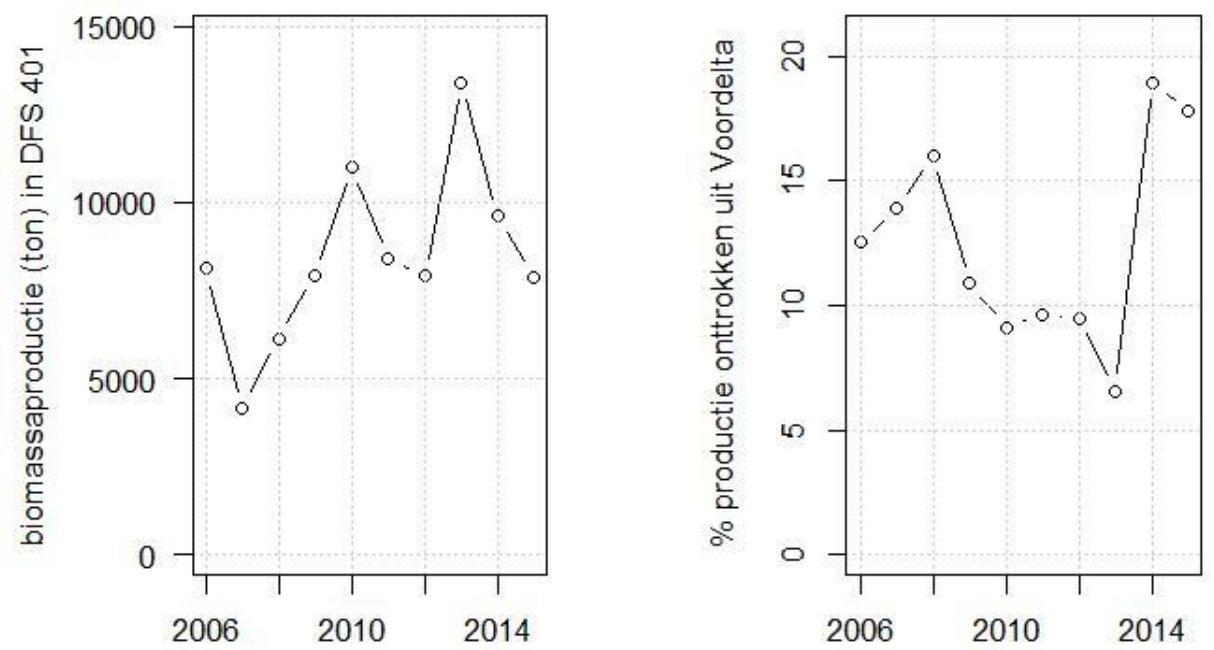

Figuur 0-46 Biomassaproductie van garnaal (>=50mm) in DFS-deelgebied 401 (links) en percentage van deze productie dat onttrokken wordt als aanlanding door de Nederlandse garnaalkotters in de Voordelta (rechts) 


\subsection{Overige soorten}

Van de bestanden die samen $95 \%$ van de discards van de platviskotters maken, wordt door ICES voor vijf bestanden ook visserij-advies gegeven: wijting, tongschar, tarbot, zandspiering en griet. Voor geen van deze bestanden is de inschatting dat de Voordelta-visserij een grote impact heeft op het bestand (zie Appendix 3 voor de details). Alleen voor wijting wordt een absolute bestandsschatting gemaakt.

\section{Wijting}

De wijting die gevangen wordt in de Voordelta is onderdeel van het bestand van de Noordzee en het oostelijk deel van het Kanaal. Voor dit bestand wordt door ICES jaarlijks bestandsschattingen gemaakt. Het wijtingbestand is niet in goede staat: De bestandsgrootte is lager dan gewenst en daalt sinds 1990 (ICES 2017). Aanwas van nieuwe vis is laag sinds 2003. De visserijsterfte is de gehele

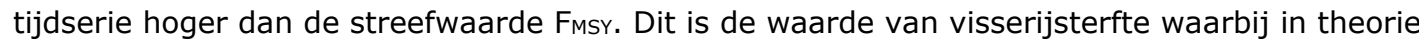
duurzame maximale vangsten gewaarborgd zijn.

Minder dan $0.03 \%$ van het wijtingbestand wordt onttrokken door de boomkorkotters in de Voordelta. Het percentage onttrekking neemt wel toe in de laatste jaren van de tijdreeks.

Het belang van de Nederlandse boomkorkotters in de Voordelta ten opzichte van de gehele visserij in de Noordzee is zeer klein: $0.03-0.33 \%$ van alle onttrekkingen zijn voor rekening van de vangsten van de boomkorkotters in de Voordelta (tabel A3.1 in Appendix 3).

\section{Overig}

Van de gehele visserij op tongschar vindt minder dan $0.002 \%$ plaats door boomkorkotters (alleen platviskotters) in de Voordelta. Van de gehele visserij op tarbot vindt minder dan $0.15 \%$ plaats door boomkorkotters in de Voordelta. Het percentage onttrekking neemt af door de tijdreeks heen. De gegevens over zandspiering en griet zijn te beperkt om uitspraken over te doen. 


\section{Totale visserij-onttrekking voor en na instelling van het BBG.}

De evaluatievraag uit het monitoringsplan (Tulp et al. 2015) die wordt behandeld in dit rapport is:

- "Wat is het effect van verschillende vormen van bodemberoerende visserij op het ecosysteem (in termen van geschatte bijvangst, onttrekking van vis, verstoring) geweest in de periode T0 (2004-2008), T1 (2009-2013) en T2 (2014-2018)?".

Deze is vertaald in de onderzoeksvraag:

- $\quad$ "Hoe groot was de onttrekking van vis en andere (bij)vangsten in de periode T0 (2004-2008), T1 (2009-2013) en T2 (2014-2018)?".

De onderzoeksvraag wordt behandeld in hoofdstuk 7.1. In hoofdstuk 7.2 wordt getracht informatie te verschaffen die kan helpen bij het beantwoorden van de evaluatievraag: Er wordt een schatting gegeven van het effect van de boomkorvisserij op de commerciële bestanden van schol, tong, wijting en garnaal, in termen van totale onttrekking (vangst, bijvangst en discards) in de drie periodes. Voor de vissoorten kan deze schatting alleen gegeven worden met betrekking tot de gehele bestanden; op Noordzeeschaal en hoger. Dit is namelijk de enige schaal waarop de bestanden leven en bestandsschattingen beschikbaar zijn. Voor garnaal is het wel mogelijk om op het niveau van de Voordelta de impact in te schatten.

Wat betreft de drie periodes (T0, T1 en T2) zoals gedefinieerd door de opdrachtgever: er zijn niet voor alle jaren in de periodes T0 en T1 gegevens beschikbaar. In hoofdstuk 7.1 en 7.2 wordt expliciet aangegeven voor welke jaren per periode wel gegevens beschikbaar waren.

\subsection{Totale onttrekking vis en benthos voor en na instelling van het BBG}

De gemiddelde hoeveelheid onttrekkingen per jaar door de garnaal- en platviskotters kan berekend worden uit de gegevens in hoofdstuk 4 en 5 . Hierbij zijn voor de door de opdrachtgever gedefinieerde periode T2 (2014-2018) alleen de gegevens van 2014 en 2015 beschikbaar. Voor periode T0 (20042008) kan alleen gewerkt worden met de gegevens vanaf 2006, omdat voor die tijd geen informatie over de aanlandingen van de garnaalkotters beschikbaar is. De discardschattingen van benthos (anders dan garnaal) worden te onbetrouwbaar geacht om mee te nemen in de opwerking: (a) uit de garnalenvisserij zijn alleen biomassaschattingen van garnalendiscards beschikbaar, terwijl ook andere benthossoorten gediscard worden en (b) uit de platvisvisserij zijn de schattingen van benthosdiscards niet representatief genoeg om te sommeren met de overige onttrekkingsschattingen (hoofdstuk 1.3.2).

Tussen T0 en T1 is de onttrekking (aanlanding en discards) van vis uit de Voordelta meer dan gehalveerd en tussen de T1 en T2 is deze nog verder afgenomen (Tabel 0-23). De aanlanding van garnaal door garnalenkotters is gelijk gebleven tussen T0 en T1, maar daarna fors gestegen. De totale onttrekking van benthos (i.e., de aanlandingen van garnaal en andere benthos en de discards van garnaal) is iets afgenomen van T0 naar T1, maar sterk toegenomen in T2. In Figuur 0-47 zijn de totale aanlandingen per jaar van de garnalen- en platviskotters uitgezet. De garnalenvisserij onttrok qua marktwaardige biomassa in alle jaren de meeste biomassa. 
Tabel 0-23 Gemiddelde onttrekking (aanlanding en discards, in ton biomassa) per jaar voor de drie periodes T0 (2006-2008), T1 (2009-2013) en T2 (2014-2015), voor de platviskotters en de garnalenkotters, opgedeeld in vis en benthos en onderverdeeld in aanlandingen en discards. Voor de garnalenkotters zijn in periode T0 alleen gegevens beschikbaar vanaf 2006, en daarom is alleen vanaf 2006 gemiddeld. *Van de benthosdiscards zijn alleen betrouwbare schattingen van garnaal beschikbaar, niet van andere benthossoorten.

\begin{tabular}{|c|c|c|c|c|c|c|c|c|c|}
\hline \multirow[b]{2}{*}{ Vis } & \multicolumn{3}{|c|}{ Platviskotters } & \multicolumn{3}{|c|}{ Garnalenkotters } & \multicolumn{3}{|c|}{ Alle kotters } \\
\hline & TO & $\mathrm{T} 1$ & $\mathrm{~T} 2$ & то & $\mathrm{T} 1$ & $\mathrm{~T} 2$ & T0 & $\mathrm{T} 1$ & $\mathrm{~T} 2$ \\
\hline Aanlanding & 772 & 302 & 229 & 76 & 68 & 70 & 848 & 370 & 299 \\
\hline Discards & 74 & 20 & 15 & 109 & 110 & 203 & 183 & 130 & 218 \\
\hline Totaal vis & 846 & 322 & 244 & 185 & 178 & 273 & 1031 & 500 & 517 \\
\hline \multicolumn{10}{|l|}{ Benthos } \\
\hline Aanlanding & 5 & 0.3 & 0.2 & 860 & 863 & 1613 & 865 & 863 & 1613 \\
\hline Discards garnaal* & 0 & 0 & 0 & 883 & 653 & 796 & 883 & 653 & 796 \\
\hline Totaal benthos* & 5 & 0.3 & 0.2 & 1743 & 1516 & 2409 & 1748 & 1516 & 2409 \\
\hline Totaal vis en benthos & 851 & 322 & 244 & 1928 & 1694 & 2682 & 2779 & 2016 & 2926 \\
\hline
\end{tabular}

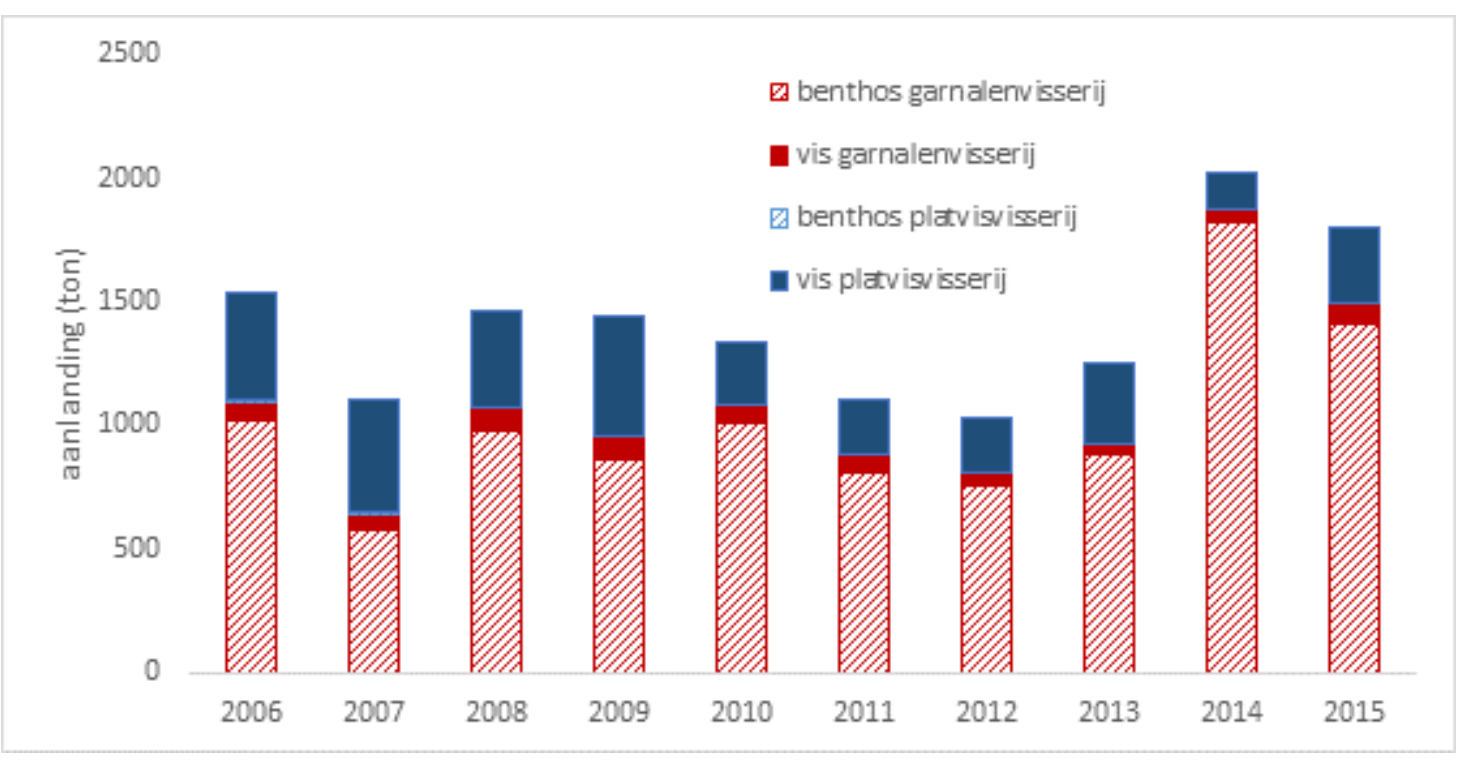

Figuur 0-47 Geschatte hoeveelheid aanlanding benthos en vis van de garnalen- en platvisvisserij, in ton biomassa per jaar.

\subsection{Effecten onttrekking vis en garnaal op commerciële bestanden voor en na de instelling van het BBG}

Om de evaluatievraag te helpen beantwoorden, is in hoofdstuk 6 voor een aantal commerciële bestanden onderzocht wat het effect van de onttrekking is geweest op het bestand. Immers, het ecologische effect van visserij-onttrekking is niet alleen afhankelijk van de hoeveelheid vis en benthos die onttrokken wordt, maar ook van de grootte van het bestand.

Voor de bestanden waarvoor schattingen van de absolute bestandsomvang beschikbaar zijn, kan vervolgens berekend worden hoeveel van het bestand wordt onttrokken in de Voordelta. Dit was mogelijk voor schol, tong, garnaal en wijting. Alleen voor garnaal kon een schatting van de 
biomassaomvang gegeven worden voor het gebied dat ongeveer de Voordelta omsloot (het gebied is iets groter, zie Figuur 0-45). Voor de vissoorten kon alleen een schatting op bestandsniveau gegeven worden. De visbestanden leven in een gebied dat groter is dan alleen zelfs de Noordzee. Het is ook deze schaal waarvoor bestandsschattingen gemaakt worden. Hieruit volgend is van alle bestanden garnaal ook het bestand waarvan de grootste fractie wordt onttrokken door de visserij ieder jaar (Tabel 0-24).

Voor tong en schol neemt de impact van de boomkorvisserij op het bestand af in de loop van de periodes. Voor garnaal en wijting is er geen duidelijke trend.

Tabel 0-24 Gemiddelde percentuele onttrekking (aanlanding en discard, in ton biomassa) uit het bestand, per jaar voor de drie periodes TO (2004-2008), T1 (2009-2013) en T2 (2014-2015). NB: Voor wijting en garnaal bestaat periode TO uit de jaren 2006-2008. De onttrekking van garnaal betreft garnaal $>=50 \mathrm{~mm}$. Leefgebied: $N Z=$ Noordzee, $S K=$ Skagerrat, oK= oostelijk deel van het Kanaal, DFS-401=het gebied 401 van de DFS (zie Figuur 0-45)

\begin{tabular}{ll|lll} 
& Leefgebied & T0 & T1 & T2 \\
schol & $\mathrm{NZ} / \mathrm{SK}$ & $0.013 \%$ & $0.005 \%$ & $0.003 \%$ \\
\hline tong & $\mathrm{NZ}$ & $0.194 \%$ & $0.072 \%$ & $0.064 \%$ \\
\hline wijting & $\mathrm{NZ} / \mathrm{oK}$ & $0.011 \%$ & $0.006 \%$ & $0.022 \%$ \\
\hline garnaal & $\mathrm{DFS}-401$ & $14.14 \%$ & $9.14 \%$ & $18.37 \%$ \\
\hline
\end{tabular}

De effecten op residente soorten in de Voordelta is niet behandeld in deze analyse omdat geen van deze van significante commerciële waarde zijn, waarvoor zodoende niet voldoende gegevens beschikbaar zijn om uitspraken te doen. 


\section{$8 \quad$ Gesprekken met vissers}

In 2016 zijn interviews afgenomen met zes vissers en twee informanten uit de Voordelta. De vissers waren geselecteerd omdat ze tussen 2004 en 2007 in de Voordelta op platvis visten. We waren in de interviews met name geïnteresseerd om van de vissers te horen welke oorzaken volgens hen de afname van platvisvisserij in de Voordelta hebben veroorzaakt (hoofdvraag 2 van dit rapport, zie hoofdstuk 1.2). Daarnaast wilden we inventariseren hoe de vissers die actief waren in de Voordelta voor 2008, de invoering van het BBG en de rustgebieden beleefd hebben. Begin 2017 werd nog een 'focused group' gehouden met een grotere groep vissers en informanten. Daarin werden de voorlopige uitkomsten van het onderzoek gepresenteerd om feedback te krijgen. Daarnaast werd ook deze vissers gevraagd welke ideeën zij hadden over de afname van de platvisvisserij in de Voordelta (meer dan elders).

Zoals ook uit de VMS-gegevens naar voren kwam (bijvoorbeeld hoofdstuk 2.1.4), kwam gedurende de interviews naar voren dat de vissers die we spraken niet eenzijdig gedefinieerd kunnen worden als 'platvisvissers'. Het zijn vissers die een gemengde visserij beoefenen, waaronder het vissen op platvis. Een tweede complexiteit is dat de Voordelta maar een van de visgebieden is van de vissers (hoofdstuk 3.1.6). De vissers maken beslissingen voor hun bedrijf op basis van een veel breder perspectief. Hun (variabele) inzet op de Voordelta in de afgelopen jaren is dan ook onderhevig aan meerdere factoren. Niettemin hebben we uit de gesprekken wel een beeld gekregen van de betekenis van de Voordelta voor de platvisvisserij en van de beleving van het BBG en de rustgebieden voor deze groep vissers.

Hieronder geven we voor verschillende onderwerpen de respons van de geïnterviewde vissers (aangeduid als visser $1 \mathrm{t} / \mathrm{m} 6$ ) en informanten (aangeduid als respondent $7 \& 8$ ) weer alsook de ideeën die vissers in de 'focused group' sessie aandroegen voor redenen van afname van de platvisvisserij in de Voordelta. In hoofdstuk 9 wordt deze informatie gebruikt om de vraag te proberen te beantwoorden waarom de platvisvisserij is afgenomen in dit gebied.

\subsection{Visserij in de Voordelta}

De Voordelta is met name van belang voor vissers uit de regio (resp 7). Veel vissers wisselen van haven in deze regio, tussen Stellendam, Scheveningen, Colijnsplaat. Scheveningen is ook standaard geworden voor Stellendamse vissers omdat de geul bij de sluis van Stellendam vaak dichtgeslibd is (iets dat volgens visser $\mathbf{3}$ erger is geworden door de MV2; ook respondent 8 benoemt dit probleem nadrukkelijk). Daar wijken ze naar uit. Veel van de vissers vissen in de zomer op platvis en in het najaar/de winter op garnalen. De vissers zelf komen veel uit Zeeland en Zuid-Holland: Goedereede, Stellendam, Zeeland, Tholen, Yerseke (Resp 7). Wat het vissen daar aantrekkelijk maakt: het is er ondiep en luw, je kan er goed terecht met slecht weer. En in de geulen zitten veel vissen die profiteren van het rijke voedselaanbod in de monding van de delta (Resp 7).

De vissers die we gesproken hebben, zijn allemaal vissers die gemengde bedrijven hebben, met eurokotters (<300 PK). Ze vissen zowel op garnalen als op vis, de verhouding tussen de twee verschilt per bedrijf en over de jaren. En met vis hebben ze vaak ook niet alleen op tong en schol maar ook op andere soorten gevist: kabeljauw, tongschar, schar, paling, kreeft, zeebaars, makreel, sprot en ansjovis. Ook vissen ze of hebben ze gevist met verschillende tuigen: garnalentuigen, kreeftenvisserij, tongentuigen (al of niet met puls), borden en ook korven. De gemengde visserij lijkt echt een kenmerk te zijn van de Voordelta vissers, sommige vissers wisselden zelfs per reis van tuigen.

Visser 6: "Als wij hier visten met de wekkerkettingen met traditioneel tuig, dan zagen we een school zeebaars aankomen dan was het hup tuigen aan dek, twee connectoren los van de vislijnen, borden eraan en een half uur later stond je met de borden eraan.(...) Dat kon zo wezen dat voor die tong het water nog net te helder was, dan ving je ze bijna niet en dan 
kwam er een fel tij, een straf tij, dan die zeebaars, dan zag je een pluk meeuwen aankomen ${ }^{15}$ dan was het jongens tuigen aan dek, de borden stonden al aan de zij, vislijnen erop en netrol afrollen en daar ging die. Dan had je soms van een paar slepen 500-600 kg zeebaars, dat kon je wel optellen".

Bovendien wordt uit de gesprekken duidelijk dat vissers gedurende de reis zich richten op verschillende doelsoorten. Visser 3 legt uit hoe hij verschillende vissoorten als doelsoort had, afhankelijk van gebied en tijd (dag / nacht).

Visser 3; "En tevens als ik hier zat, overdag Oosterschelde, 's nachts daar naartoe dan ving je soms op een nacht $200 \mathrm{~kg}$ grove tong, zeebaars erbij, overdag weer terug. Op den duur zeiden ze 'nou dit gebied gaat dicht' dus als je overdag op de Oosterschelde viste, dat wordt's nachts minder - dan ga je niet effetjes die kant op [langs de Belgische kust], daar is gewoon de afstand te groot voor. Dan moet je echt daar blijven hè".

Visser 3: "Wij vinden het zelf ook veel afwisselender om een paar dagen tong te kunnen vissen, en op een gegeven moment zie je dat de makreel of de mul goed is, of de zeebaars, nou dan doen we een dagje dat. Of kreeft, ik vind het gewoon mooi om dat af te kunnen wisselen. Ook voor die bemanning anders .. tenminste ik vind het best wel eentonig om een heel jaar dezelfde visserij .. dan hebben we van januari tot maart kabeljauw gevist".

Bovendien vertelde hij ook, hoe hij - doordat hij daar was - observaties deed voor zijn vader die met een klein bootje een aantal verschillende visserijen deed, o.a. op zeebaars.

Visser 3: "Plus als ik hier zat, dan zag je vaak in juli, augustus, van oh, hier ga je een beetje zeebaars zien langs die banken, hè dat gaat een beetje opleven. Mijn vader die viste steeds veel met de ringzegen op harder en zeebaars, daar had ik dan contact mee. Dan waren we hier aan het vissen 's nachts, belde ik naar huis en dan zag je met de dag die meeuwen allemaal duiken op die aasvis en dan belde ik mijn vader en dan zei ik de zeebaars is actief en dan kwam hij van zijn boot af. Zo kon je elkaar helpen en dan ging hij met de ringzegen langs die plaatjes en dan had hij daar een mooie dag met zeebaars". Onderzoeker 1: "En als je er nu niet meer op tong vist dan heb je niet meer zo veel gevoel bij de zeebaars ook?" Visser $\mathbf{3}$ : "ja dat is natuurlijk een combinatie van hè. Het is een paar weken dan zie je in juli dan gaat dat beginnen dan gaan ze jagen. Dan zijn ze actief en dan gaf je dat door, ja als ik niet meer in dat gebied actief mag wezen 's nachts, dan kom je daar niet meer dus je kan dat ook niet meer waarnemen. Dus het was vaak, dan moest hij zelf er naar toe en kijken, 'is het nog wat?'".

\footnotetext{
${ }^{15}$ De meeuwen jagen op vis die door een school zeebaarzen opgejaagd worden.
} 
Tabel 0-25 overzicht van visserij die de vissers nu beoefenen, waar en wanneer.

\begin{tabular}{|c|c|c|c|}
\hline & Wat: & Waar: & Wanneer: \\
\hline \multirow[t]{2}{*}{ Visser 1} & Garnalen & Hollandse kust & \\
\hline & Tong & Hollandse kust & \\
\hline \multirow[t]{2}{*}{ Visser 2} & Garnalen & Voordelta en kustzone & najaar, winter \\
\hline & Tong & Langs hele NL kust & zomer \\
\hline \multirow[t]{3}{*}{ Visser 3} & Garnalen & & najaar \\
\hline & Tong & & voorjaar \\
\hline & Borden (zeebaars) & & zomer \\
\hline Visser 4 & Garnalen & Tot aan Denemarken aan toe & hele jaar \\
\hline \multirow[t]{2}{*}{ Visser 5} & Garnalen & Hele voordelta & aug-jan \\
\hline & Tong / schol & Belgische kust & maart-juni (3-4 wkn) \\
\hline \multirow[t]{2}{*}{ Visser 6} & $\begin{array}{l}\text { Garnalen, } \\
\text { Tong }\end{array}$ & $\begin{array}{l}\text { Voordelta en kustzone } \\
\text { Noordzee }\end{array}$ & $\begin{array}{l}\text { Najaar, winter } \\
\text { maart - september ( } 8 \\
\text { wkn) }\end{array}$ \\
\hline & Kreeft & $\begin{array}{l}\text { Noordzee, boven de } \\
\text { Waddeneilanden }\end{array}$ & zomer \\
\hline Respondent 7 & $\begin{array}{l}\text { Betrokkene bij Voordelta } \\
\text { visserij }\end{array}$ & & \\
\hline Respondent 8 & $\begin{array}{l}\text { Betrokkene bij Voordelta } \\
\text { visserij }\end{array}$ & & \\
\hline
\end{tabular}

\subsection{Impact van het BBG op de visserij}

Alle vissers $(\mathrm{N}=6)$ geven aan dat de maatregelen het meeste impact hebben gehad op hun garnalenvisserij.

Onderzoeker 1: "De maatregelen in de Voordelta, (...) op welke van uw visserij is dat het meest ingrijpend geweest?" Visser 4: "Op de garnalenvisserij".

Onderzoeker 2: "Dus wat nu BBG is, daar viste je vroeger?" Visser 6: "Ja, zeker voor de garnalen. Dat is absoluut zo. Het beschermingsgebied wat dat je nu hebt, waar die boeitjes nu liggen [dat zijn de rustgebieden], dat was gewoon ons visbestek voor de garnalen".

Onderzoeker 1:"Is het ingrijpender geweest voor de platvisvisserij of voor de garnalenvisserij (het hele pakket aan maatregelen)?" Visser 5: "Niet voor de platvisvisserij hoor, voor de garnalenvisserij. Ja de garnalenvissers waren daar gewoon altijd actief. Nog steeds, maar in mindere mate nu. Onderzoeker 1: "Maar er waren ook platvisvissers actief toch?" Visser 5:"Ja maar niet zoveel".

Visser $\mathbf{2}$ is er heel uitgesproken over dat hij met name in zijn garnalenvisserij is geraakt door de maatregelen in de Voordelta, dat geldt voor hemzelf en hij is er 'absoluut zeker' van dat dit ook geldt voor de visserij in het algemeen.

Die impact op de garnalenvisserij is er op drie verschillende manieren.

1) Allereerst omdat bepaalde gebieden afgesloten zijn voor de garnalenvisserij (binnen de boeien mag niet gevist worden) en het waren goede gebieden; 


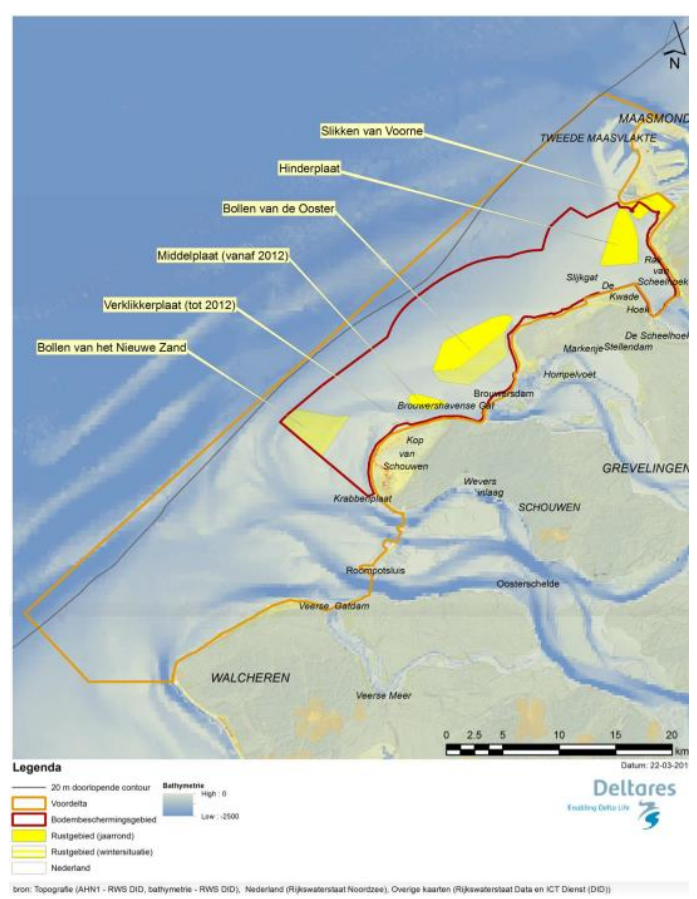

Visser 6: "Ja garnalen zoeken op een gegeven moment de droogte weer op, als er bepaalde temperaturen zijn. (...) Dat zijn echt garnalenbestekken op bepaalde periodes. Die zitten er niet altijd, maar dat begint wel weer te komen. Dat is meestal in het najaar hè."

Visser 5: "Het is ook gewoon een goede visplek. En vooral dit hoekje, het Brouwershavensegat (tekent in op kaart). Er zitten gewoon enorm veel garnalen, sommige dagen".

2) ten tweede omdat die gebieden bij slecht weer wel geschikt waren om te vissen omdat ze relatief beschut zijn voor de deining;

Visser 5: "Want vooral ja, die gesloten gebieden zeker in de winterdag of in het najaar dat was ook voor ons dat het een beetje een beschermd gebied, een schuilplaats was tegen de najaarsstormen. Maar ja nu is dat gebied gesloten".

3) ten derde omdat het de visserij kan onderbreken (vissers moeten hun tuigen ophalen). Hun visvisserij is meer geraakt geweest door de aanleg van de Tweede Maasvlakte dan door de sluiting van het BBG in de Voordelta.

Visser 4: " En dan, dan stopt het hier. Dus dan moet ik nog een paar uur wachten. En dan lig $i k$ hier opgesloten. Want ik kan dan niet meer verder. Want ik kan niet door dat gebiedje.

Dus dan blijven we hier vissen maar ja, dan is het natuurlijk... voor mij. Dan ga je maar weer die kant op. Ook of, of je vaart rond, en dan eh, gaat hier dat stukje weer. Je gebied, je bevisbare gebied wordt natuurlijk zo beperkt".

Uit de data blijkt dat de meeste visvisserij al voor 2008 sterk was afgenomen in de Voordelta (hoofdstuk 3). De meeste vissers die we nu spraken, gaven dan ook aan dat het BBG niet echt impact heeft gehad op hun platvisvisserij.

Onderzoeker 1: Want het BBG is in 2008 ingesteld, heeft dat ook effect gehad op uw visserij op tong? Visser 5: Nee hoor, nee, niet echt nee. We kwamen er wel eens maar niet veel. En dan was het nog een beetje buiten het gebied. Dus voor ons heeft het echt geen impact gehad.

Eén van de informanten waar we mee gesproken hebben, schetst de geschiedenis van de instelling van het BBG in de Voordelta en benoemt als mogelijke verklaring voor de afname van boomkorinzet voor 2008 dat veel vissers doordat ze al een aantal jaar (sinds 2002) op de hoogte waren van de ontwikkelingen in het gebied, de sluiting niet afgewacht hebben maar geanticipeerd hebben op de diverse sluitingsopties en hun visserij al zijn gaan verleggen (respondent 7). Visser $\mathbf{2}$ geeft aan dat hij het niet precies weet hoe het komt dat de boomkorvisserij al voor 2008 weg trok uit de Voordelta. Noemt dat dit een periode was dat er veel schepen uit gingen. Op de vraag wat mogelijke 
overwegingen voor mensen waren om te stoppen speculeert hij: 'geen opvolging, dure brandstofprijzen, en gewoon niet meer het positieve kunnen zien van de visserij'. Hij zegt ook dat de visserij ieder jaar anders is, dat je niet kan voorspellen wat er gaat gebeuren. Hij noemt ook nog dat vroeger in de Voordelta op kokkels en mosselen gevist werd, dat daardoor misschien een ander voedselaanbod ontstond. Ook visser 6 denkt dat een ander voedselaanbod een belangrijke verklaring is. Visser 1 noemt ook gebrek aan opvolging als reden voor het verdwijnen van bedrijven.

In de voor platvisvisserij gesloten gebieden visten de meesten al niet meer voor 2008, hooguit om doorheen te vissen op weg naar de goede gronden.

Onderzoeker 1: "Ja.. en als u nou morgen weer daar zou kunnen vissen zou u dan meteen weer daar gaan vissen? Visser 3: "Op de tong zou ik dat wel graag willen. Dat was ook zoiets, we hebben in mei hier onder de waterweg gevist dat is ook een plekje, net buiten de hinder zeg maar, net onder die geul van de nieuwe waterweg. Dan kwamen we uit de sluis gevaren hier en ja normaal vroeger dan zou je zeggen, ik zet hier en ik vis zo langs de Ooster naar boven naar hier. Kon je wel dat traject vissend afleggen. Nu moeten we heel dat stuk stomen naar hier. Dus we moeten eerst 3 uur varen om hier te komen, eer dat je pas met je visserij kan beginnen. Voor 2008 dan visten we hier zo langs de ooster en dan kon je zo.. dus dat is ook weer wat je ingeleverd hebt".

Volgens de vissers is de Voordelta al ver voor 2008 minder interessant geworden voor vis.

Visser 4: "Daar zit gewoon geen vis meer Afijn je ziet het ook gewoon d'r is hier eh, hier zeker dat stuk voor de kering (....). Affijn deze stukken ook. Deze (...) ja nou als daar garnalen zijn maar voor de rest, niet meer op wat anders". Onderzoeker 1: "En weet u ongeveer wanneer dat begon dat men daar niet meer kwam?" Visser 4: "Dat is van lieverlee verminderd eigenlijk. Ook sinds 2000 eigenlijk".

Visser 6: "15 jaar terug dan kwam 's maandags, dan lagen we van Westkapelle tot een beetje hier dit gebied, de monding van de Oosterschelde, dan lagen we met zes man te vissen op de tongschar eerst. Nou dan ving iedereen 4-5000 kg tongschar 's maandags, dan ging je 's nachts een beetje de tongbestekken opzoeken. Als je er nu komt, beoosten die lijn, nou je ziet gewoon niks meer".

Visser 6: "Als er geen vis zit, dan vis je er niet. Zo makkelijk is het. Kijk kan ik hier één mandje vangen en daar 2 mandjes, dan ga ik dat daar doen".

De belangrijkste verklaring zien ze in aanleg van de 'kunstwerken' (visser 5) en het kierbeheer: de dammen, sluizen en keringen. Die hebben het gebied zwaar beïnvloed en de vissers nemen aan dat dat (mede) invloed heeft gehad op de visstand.

Visser 3: "Ik denk ook door heel die verandering van de Maasvlakte en afsluiting van die zeearm dat gewoon bepaalde vissoorten er niet meer willen verblijven". (...) Dus wij denken dat het gewoon een andere oorzaak is. Niet de visserij maar dat het gewoon door afsluiting van die zee armen, dat dat een veel grotere impact [heeft] en die Oosterschelde kering. Want als je nu uit de Oosterschelde komt dan kom je al allerlei soorten wier tegen, veel vuil. Kom je op de Westerschelde, dat is een open zeearm, dan heb je dat niet. Het stroomt veel meer door, terwijl in de monding van de Westerschelde zie je veel meer trekvissen, hier zie je veel meer jonge vis, jonge zeebaars, hierzo [wijst op de kaart].

Visser 5: "dat ligt gewoon aan de kunstwerken zoals ze het noemen, net zoals de stormvloedkering, dammen en sluizen, die hebben het allemaal tegen gehouden".

Visser 6: "'Die voordelta is helemaal veranderd, je hebt natuurlijk de kering gekregen, alle keringen, dat is natuurlijk goed voor de bescherming, maar het verandert toch. En wij zien dat ook echt. Alles verlegd, het gaat allemaal naar binnen toe.(..) Je had vroeger de hinderplaat en de oosterplaat, die lagen veel meer in zee en daarachter [tussen de plaat en de kust] kon je dan veel beter vissen. (...) de hinderplaat is helemaal naar binnen gekomen". (...) Die harde stroming enzo, dat is verplaatst. En ik denk, voor mijn gevoel, dat die stuw zoveel water tegenhoudt, daar is geen stroming meer naar buiten toe, dat komt ook door de delta werken, verwacht ik zo dat je die stroming niet meer zo hard naar buiten toe hebt en iedere keer dat je wind hebt, dat is de enige factor die dan nog krachtig kan zijn en die huppelt 'm steeds verder naar binnen toe. Bij wijze van spreken. Dus de stroming heeft minder invloed dan de wind, en dan wat het vroeger geweest zou zijn".

Ook de aanleg van de tweede Maasvlakte wordt veelal $(\mathrm{N}=4 / 7)$ genoemd als verklaring voor veranderingen in het gebied. 
Visser 6: "Die visserij begon toen eigenlijk al te veranderen, dat is meer met de MV2 gekomen, dat dat gewoon minder werd, daar, een beetje droog om te vissen. Toen die tijd, deden we ook wel eens een keer, hier binnen de Ooster, dus bij Ouddorp daar bij de aardappelbult, daar deden we ook nog wel eens tongschar, op tongschar vissen, in de sleufgaten. Maar ja die Ooster is ook helemaal naar binnen toe gekomen, dat is een stuk droger geworden, dus dat is ook moeilijker om te gaan vissen daarzo. Je hoort er ook niet meer van, van tongscharvangsten.".

Resp 7: "Vissers merkten ook op dat door de bouw van de MV2 er meer stof in het water was, wat niet goed was voor de tongvangsten, want die vang je liefst met helder water. RWS deed hier wel metingen van, maar het was moeilijk hard te maken, en volgens de vissers maten ze op de verkeerde momenten".

Voor een aantal van deze vissers was de Tweede Maasvlakte ook gewoon een mooi visgebied.

Visser 1: "Dan denk ik jongens... het was zo een mooi visgebied, er zat zoveel jong broed altijd". [wijst op stukje zee op kaartje waar nu MV2 ligt].

Visser 3: "Wij visten hier waar nu de Maasvlakte ligt, die tweede, daar visten we altijd kabeljauw net buiten die dam. Dat gebied is ook gesloten nu, daar kun je niet meer komen dat is haven geworden".

Ook voor visser 2 was de Tweede Maasvlakte interessant, hij viste daar op grote tongen en schollen. $\mathrm{Nu}$ vist hij wat meer zuidelijk van de MV2 dan voorheen en eromheen.

Een aantal vissers geeft aan te zijn gestopt met de tongenvisserij vanwege competitie. Eén wijst op de toename van het aantal schepen dat in de 12-mijl kwam vissen (rond 2000), en verteld de overstap gemaakt te hebben naar de kreeftenvisserij (visser 6). Twee anderen wijzen op de komst van de puls. Ze vissen niet meer op tong omdat het niet meer rendabel is om dat te doen zonder puls (met name na 2014).

Visser 5: "Sinds de puls is het voor ons niet meer rendabel, om zonder puls met de traditionele boomkor tong te vissen. Dat is niet meer rendabel voor ons".

Vissen in de Voordelta betekent dat je goed je bestekken moet kennen.

Visser 3: "maar voor de rest op de tongvisserij waren wij een van de weinigen die dat deden [bij de bollen van het nieuwe zand - MK]. Omdat het best wel, je moet precies die geultjes weten en die bankjes. De meeste mensen die zien daar toch een beetje van af om dat het ieder jaar verschuift. Het is natuurlijk het gevaar dat je aan de grond loopt".

Hij vertelt dat hij die precieze kennis van zijn vader geërfd heeft, die geleerd heeft, in zijn zeebaars visserij om precies de randen van de banken te zien aan de stroom 'rafelingetjes' op het water ("dan zie je dat tij erover gooien").

Visser 3: "Het was een mooi gebied, het is jammer dat het weg gehaald is". Aangezien een kustzone ieder jaar weer anders is, het is een dynamisch gebied, laat de visserij inspanning ook veel variatie zien (resp 7). Vissers 2 en 6 onderschrijven deze dynamiek. Veel vissers geven dan ook aan dat ze graag wel weer zouden willen proberen te vissen in de gesloten gebieden om even te kijken hoe het er voorstaat. Daarnaast benadrukken een aantal vissers dat ze het vreemd vinden dat de gebieden vast liggen terwijl het gebied aan veel verandering onderhevig is, waardoor ook de soorten zich verplaatsen (o.a. zeehonden en vogels).

In de focused group worden een aantal mogelijke oorzaken genoemd voor de sterke afname van de platvisvisserij in de Voordelta. Net zoals de vissers die geïnterviewd zijn benoemen ze met name de invloed van de deltawerken op het gebied: de Oosterschelde is enorm veranderd, de stroming, de stroomsterkte. De kraamkamer functie van het gebied is o.a. onder invloed van die ingrepen enorm veranderd.

Visser FG1: "De verandering van de VD hangt samen met de watersnood ramp. Dat heeft geleid tot een ingreep in de natuur, dat kun je verklaren. Ja er is minder visserij, maar er is ook geen kraamkamer functie meer in de Oosterschelde".

Visser FG2: "Als het water troebel is, dat noemen we dik water - dan heb je voedsel voor de vis. Vroeger zwommen de tongen tot Tholen - toen was er natuurlijke stroming, maar nu zie je een donkere massa water in de Oosterschelde. In de Westerschelde is het troebel. In helder water zit niks". 
Andere invloeden die genoemd zijn waren: baggeren in het slijkgat, de toename van het aantal zeehonden in het gebied, temperatuurstijging van het water onder invloed van klimaatverandering. Ook werd gewezen op mogelijke indirecte effecten zoals het voedselaanbod voor vis (plankton).

\subsection{Nut van de maatregelen}

Volgens visser 2 hebben de maatregelen op de Voordelta totaal geen zin gehad. De zwarte zee-eend komt juist waar gevist wordt, 'in die zandbergen' kunnen de vogels volgens visser 2 anders geen eten vinden. Ook is het gebied heel dynamisch, de zandbanken veranderen steeds, dus het sluiten van zo'n gebied voor visserij heeft volgens deze visser geen zin. Visser 1, geeft n.a.v. discussie Vlakte van Raan ook een voorbeeld hoe lastig het is om gesloten gebieden te realiseren in een gebied met verschillende dieptes die zich ook verplaatsen:

Visser 1: "Ik begrijp het ook wel, kijk uit dat oogpunt begrijp ik het wel, maar ja het stikt bijvoorbeeld al van de wrakken daar zo, daar moeten we al om heen vissen weet je wel, dus zulke kleine dingetjes. Die maken het gewoon lastig kijk en dit gebied is weer dan kom je hierzo aan vissen, en nu vroeger kon je dan door maar nu zit je op die bank als ik het zo uit mijn hoofd goed heb, dus dan moet je in principe gaan halen om die bank over te kunnen en dan kan je weer zo verder".

Visser 5 reageert op de vraag 'heeft $u$ het idee dat het iets heeft veranderd?'

Visser 5: "Totaal niets, het is gewoon om het even. Nee hoor, er is gewoon niets veranderd, absoluut niets. Ja voor ons (grinnikt) maar niet ecologisch, niks. (...) De natuur moet je gewoon zijn gang laten gaan. (...) Die paar bewegingen van die vissers. (...) Wat is nog natuur? Natuur is wat je daar gewoon in zijn waarde laat. Maar niet een stormvloedkering bouwen, een Haringvlietsluizen gaan bouwen, een Maasvlakte, een Tweede Maasvlakte, dan praat je niet meer over natuur. Dan is het over natuurbehoud. Ja wat er dan nog is, dat stukje, dat moeten we maar sluiten dan ja..., ja... dat trekt gewoon helemaal nergens op. Wat is nog natuur? Gewoon de natuur de natuur laten. (...) Het regelt zichzelf, die kunnen we niet sturen".

Onderzoeker 2 bevraagt visser 6 over zijn inschatting dat de BBG geen effect hebben, dat hij dat beziet vanuit de visserij. Dat het voor vis/garnaal geen effect heeft.

Visser 6: "Ja ja ik weet niet wat voor 'n ecologie dat op zo'n zandplaat zelf zit, wat daaraan verandert, maar ik weet wel dat als zo'n zandplaat elk jaar zo'n 10 of $15 \mathrm{~cm}$ verzet wordt, naar binnen toe, wat ie dus doet, nou hoeveel miljoenen tonnen met zand gaat er over heen? Nou dat is wel effe anders, dan dat ik er met mijn klosje langs heen kom. Maar dat plantje wat of er dan is, dat komt er dan ook niet, want dat verzandt dan ook, snap je wat dat ik bedoel? En dat, ja dat vind ik het teleurstellende ervan, dat ze daar geen erg in houden, van nou wat doet de natuur nou zelf".

In de focused group hebben we vissers niet direct bevraagd over het nut van de maatregelen. Wel werd het onderwerp vanzelf aangesneden door een aantal vissers. Het nut van de natuurcompensatie werd betwijfeld. De impact van de natuur op de bodem (stroming, storm, getij) werd door de vissers als veel groter ingeschat in vergelijking met dat van bodemtuigen. Ook werd genoemd dat de PMR vooral een politieke oplossing was; natuurcompensatie door het uitruilen van gebruiksfuncties (landwinning voor visserijvermindering). Het verbaasde de informanten niet dat er waarschijnlijk geen noemenswaardige effecten gevonden zijn. 


\section{$9 \quad$ Oorzaken van de veranderde platvisvisserij}

\subsection{Vragen}

Zoals in fase 1 van het PMR project ook is vastgesteld, is de visserij-inspanning van de platviskotters in de Voordelta sinds 2004 gedaald. Deze daling wordt veroorzaakt door zowel een daling van het aantal actieve platviskotters als van de inspanning per actief schip (Figuur 0-7). Ook de aanlandingen vanuit de Voordelta zijn sinds 2004 afgenomen (Figuur 0-25). Wat zijn de redenen achter deze veranderingen? Deze vraag wordt hier op de volgende manier benaderd:

\section{Hoe uniek zijn de veranderingen?}

a. Zijn de veranderingen uniek voor de Voordelta of hebben de vissers hun gedrag in een groter visgebied aangepast? Hierbij wordt onderscheid gemaakt tussen de gehele visserij (Noordzeebreed) en de kustvisserij van deze kotters. Als de patronen ook in een groter visgebied te zien zijn, dan zijn ze dus niet uniek voor de Voordelta.

b. Zijn deze veranderingen uniek voor de periode vanaf 2004 of spelen ze al langer?

2. Als er veranderingen uniek voor de Voordelta in de periode 2004-2015 zijn:

Wat is de oorzaak van de veranderingen in de Voordelta? En meer specifiek: Heeft de instelling van het Bodembeschermingsgebied een rol gespeeld?

\subsection{Hoe uniek zijn de veranderingen?}

\subsubsection{Voordelta versus Noordzee}

- De totale hoeveelheid inspanning: Het aantal visuren van deze kotters is ook Noordzeebreed sterk afgenomen (Figuur 0-13). Echter, de inspanning in de Voordelta neemt harder af (Figuur 0 -14). De reden voor de afname van de visserij in de Voordelta is dus deels op hogere schaal te vinden, maar ook deels Voordelta-specifiek.

- Het aantal actieve platviskotters: In de gehele Noordzee en in de Voordelta neemt het aantal actieve schepen even hard af (Figuur 0-13). Het aandeel van de actieve schepen dat (ook) in de Voordelta vist, verandert niet door de jaren heen (Figuur 0-14). Er is dus geen Voordeltaspecifieke afname in aantal actieve platviskotters.

- De gemiddelde inspanning per actief schip: Deze neemt af in de Noordzee tot en met 2008, maar niet in even grote mate als in de Voordelta (Figuur 0-7 en Figuur 0-13); met 22\% van 2004 naar 2008 in de Noordzee, en met 44\% in de Voordelta. Er lijkt dus deels een Voordeltaspecifieke afname in inspanning per actief schip te zijn.

- $\quad$ Ook een visser geeft in de interviews (hoofdstuk 7) aan dat veel schippers in zijn geheel zijn gestopt aan het begin van de eeuw.

Conclusie: De afname in visserij van de platviskotters in de Voordelta is grotendeels terug te zien in Noordzeebrede ontwikkelingen. Het is dus niet zo dat de visserij alleen in de Voordelta is afgenomen. Zo is de afname in het aantal actieve schepen gelijk tussen de Voordelta en de Noordzee. Echter, de afname in inspanning in de Voordelta is wel groter dan Noordzeebreed.

\subsubsection{Voordelta versus Noordzeekust}

De totale hoeveelheid inspanning/het aantal actieve platviskotters/de gemiddelde inspanning per actief schip: De patronen van de visserij in de kustzone (binnen de 12-mijl-zone en binnen de 6-mijl-zone) zijn gelijk aan die van de gehele Noordzee (Figuur 0-16). Ook de trend in het aandeel van de visserij in de Voordelta ten opzichte van de kust vertoont hetzelfde patroon als 
ten opzichte van de gehele Noordzee (Figuur 0-17). Er lijkt dus geen kust-specifieke ontwikkeling in platvisvisserij te hebben plaatsgevonden.

Conclusie: De visserij van de 68 platviskotters heeft zich hetzelfde ontwikkeld in de Noordzeekust (binnen de 12-mijl-zone en binnen de 6-mijl-zone) als Noordzeebreed. De afname in inspanning in specifiek de Voordelta is dus niet te verklaren vanuit een verandering in de kustvisserij.

\subsubsection{Tijdsperiode}

- $\quad$ De afname in de Voordelta tussen 2004-2015 is deel van een langere trend: vanaf het begin van de tijdreeks (1997) is al een sterke reductie in het belang van het gebied (32F3) te zien (Figuur 0-31). De sterkste afname lijkt net na de eeuwwisseling ingezet te zijn.

- Ook de vissers geven in interviews aan (hoofdstuk 7), dat hun verminderde interesse in de Voordelta al veel langer speelt. Een veel genoemde reden zijn de 'kunstwerken' die in de Voordelta zijn aangelegd, zoals het Haringvliet en de Oosterscheldekering. Dit heeft het gebied op meerdere manieren onaantrekkelijker gemaakt als visgrond.

- $\quad$ Rond 2008/2009 lijkt het belang van de Voordelta in de gehele platvisvisserij zich te stabiliseren op een laag niveau (Figuur 0-14, Figuur 0-15). Het feit dat deze stabilisatie plaatsvindt ten tijde van de creatie van de Maasvlakte2 en het BBG roept de vraag op of er wellicht meerdere processen tegelijk spelen: (1) een afname van de Voordelta-visserij die over een grotere tijdsperiode plaatsvindt, veroorzaakt door andere factoren, vermengd met (2) een invloed van de Maasvlakte2 en het BBG later in de tijd.

Conclusie: De afname in het relatieve belang van de Voordelta-platvisvisserij lijkt deel te zijn van een trend die al veel langer aan de gang is. De grootste afnames vonden plaats voorafgaand aan 2004. Wel lijkt rond 2008/2009 het belang van de Voordelta te stabiliseren op een laag niveau. Dit impliceert een mogelijke invloed van MV2/BBG in de laatste jaren van de tijdreeks.

Deze laatste hypothese kan verder onderzocht worden, als de visserijgegevens opgesplitst worden naar de schepen die blijven vissen in de Voordelta na de instelling van het BBG en de schepen die stoppen (Figuur 0-48). Schepen die alleen voorafgaand aan 2008 in de Voordelta vissen, zijn al vanaf 2005 vrijwel niet meer aanwezig in de Voordelta. Schepen die blijven vissen in de Voordelta, brengen pas vanaf 2008 minder tijd door in de Voordelta. Dit bevestigt het idee dat er twee processen hebben plaatsgevonden.

De vissers die gestopt zijn speelden alleen in 2004 een redelijk grote rol in de Voordelta (40\% van de totale Voordelta-inspanning), vanaf 2005 bestond de Voordelta-visserij voornamelijk uit vissers die ook in latere jaren hier bleven vissen.
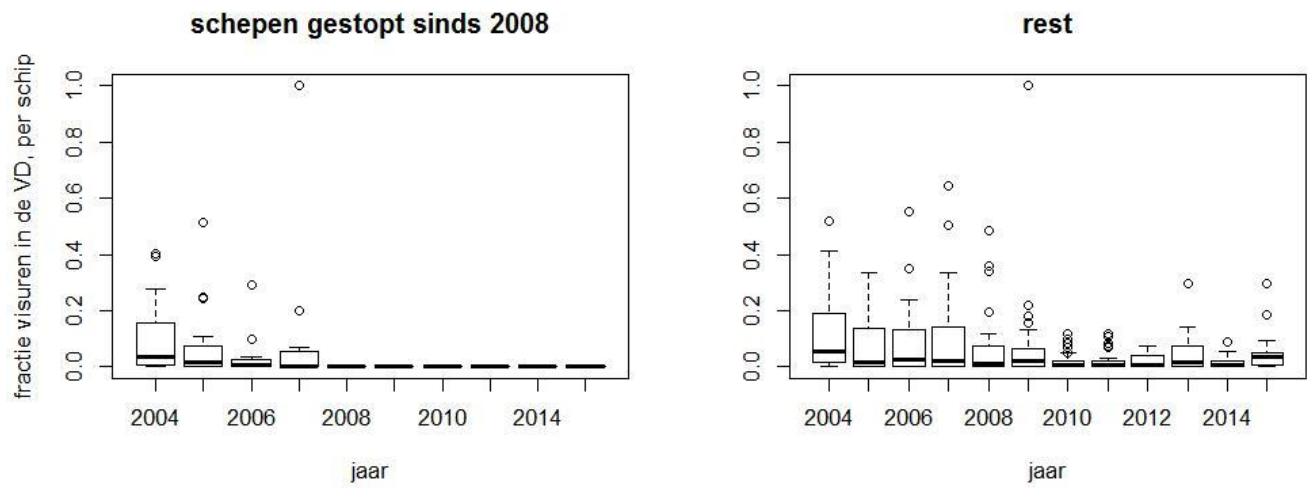

Figuur 0-48 Boxplot van de fractie visserij inspanning in de Voordelta van de 68 platviskotters die tussen 2004-2015 in de Voordelta actief zijn geweest, van hun totale inspanning als platviskotter: opgesplitst naar kotters die niet meer gevist hebben in de Voordelta sinds 2008, en de rest. 


\subsection{Wat is de oorzaak voor de verandering in specifiek de Voordelta?}

Hoewel het grootste deel van de afname in Voordelta-visserij verklaard kan worden door Voordeltaoverstijgende factoren, zijn er wel ook signalen dat de instelling van het BBG/MV2 een aanvullende rol kan hebben gespeeld. Wat kunnen de oorzaken zijn van de Voordelta-specifieke veranderingen? De redenen worden opgedeeld in twee categorieën; (i) negatieve veranderingen in de platvisbestanden, en (ii) veranderingen in de vloot en het beleid (waaronder de instelling van het BBG).

\subsubsection{Ontwikkelingen in de platvisbestanden}

Een mogelijke reden is dat de hoeveelheid maatse platvis specifiek in de Voordelta is achteruitgegaan sinds 2004, waardoor de vloot in andere gebieden is gaan vissen. Deze hypothese wordt niet ondersteund als het commerciële vangstsucces van de Voordelta wordt vergeleken met het vangstsucces Noordzeebreed (Figuur 0-29). Het commercieel vangstsucces in de Voordelta is in de meeste jaren hoger dan die Noordzeebreed. Ook neemt het vangstsucces binnen de Voordelta niet af door de jaren, en neemt deze voor tong zelfs redelijk sterk toe. Patronen in vangstsucces zijn echter niet eenduidig op deze manier te interpreteren om twee redenen. Ten eerste kunnen vissers wellicht met een paar trekken inschatten hoeveel vis aanwezig is in een gebied en stoppen met vissen voordat hun vangstsucces afgenomen is. Het is dus an sich geen overtuigend bewijs dat de platvis in het gebied niet is afgenomen. Ten tweede is de schatting van het vangstsucces in de Voordelta een grovere schatting dan die Noordzeebreed ${ }^{16}$. Patronen in de Voordelta moeten dus ook met meer terughoudendheid geïnterpreteerd worden. Echter, ook met deze terughoudendheid wijst het vangstsucces in de Voordelta niet op afnemende bestanden: het vangstsucces neemt niet af en ligt niet lager dan in de Noordzee.

Een ander indirect signaal komt uit de bestandschatting van de doelsoort van de platvisvisserij: Volwassen tong neemt in zijn gehele Noordzeebestand toe door de jaren (Figuur 0-42). De hoeveelheid tong in de Voordelta is niet gelijk aan de totale hoeveelheid (de hoeveelheid in de Voordelta kan afnemen terwijl deze bestandswijd toeneemt), maar een sterke toename van het tongbestand maakt een afname van Voordelta-tong wel onwaarschijnlijker.

Vanuit eerdere studies zijn er aanwijzingen dat de verspreiding van platvis opgeschoven is naar dieper water. Deze verschuiving heeft zich echter al voorgedaan aan het einde van de vorige eeuw (van Keeken et al. 2007) en kan daardoor geen verklaring zijn voor de veranderingen vanaf 2004. Bovendien zou dit de inspanning van de gehele kustvisserij moeten beïnvloeden en niet alleen de Voordelta.

De vissers geven in interviews aan dat de bestanden in de Voordelta wel zijn afgenomen, maar dat dit in eerdere jaren plaatsvond, ingegeven door de grote structurele werken zoals de Oosterscheldekering (hoofdstuk 7).

Conclusie: De voorzichtige conclusie is dat de redenen voor de verminderde inspanning van de platvisvisserij sinds 2004 in de Voordelta niet lijkt samen te hangen met Voordeltaspecifieke ontwikkelingen in de doelsoort van de visserij sinds 2004.

\subsubsection{Ontwikkelingen in de vloot en het beleid}

Ontwikkelingen in de platvisvloot in de Voordelta kunnen ook veroorzaakt zijn door andere factoren dan de doelsoorten waar ze op vissen. Zo kan de toename in de garnalenvisserij en/of de instelling van het BBG een rol hebben gespeeld. Hieronder worden vier mogelijke processen uiteengezet en wordt gekeken of de beschikbare gegevens deze hypotheses ondersteunen.

${ }^{16}$ De totale aanlanding van een visreis wordt evenredig verdeeld over de 'vissende pings' in die reis; zowel binnen als buiten de Voordelta. Er is dus niet voor de Voordelta-locaties een directe schatting van het vangstsucces te maken. 
(i) Vissers zijn overgestapt van platvisvisserij op garnalenvisserij in de Voordelta.

Dit kan veroorzaakt zijn door de instelling van het BBG, of bijvoorbeeld omdat de productiviteit van garnaal in specifiek de Voordelta gestegen is.

De vissers die tussen 2004 en 2015 met beide tuigen hebben gevist vissen vrijwel allemaal hoofdzakelijk als garnalenkotter in alle jaren (Figuur 0-24). Er is maar bij twee schepen - met weinig inspanning- een omschakeling te zien van platvisvisserij naar garnalenvisserij rond 2008.

Ook de vissers geven in de interviews niet aan dat omschakeling naar garnaalvisserij meespeelde in het besluit minder in de Voordelta te vissen (hoofdstuk 7).

Conclusie: De kotters hebben in deze tijdperiode altijd hoofdzakelijk op garnaal gevist in de Voordelta. Het belang van de garnalenvisserij is wel toegenomen.

(ii) Platviskotters zijn vertrokken naar andere gebieden door toenemende drukte door de groeiende garnalenvisserij.

De tijdreeksen van de inspanning van de twee visserijen (Figuur 0-7 en Figuur 0-18) ondersteunen deze hypothese niet. De platvisvisserij neemt vanaf 2004 vrij consistent af tot en met 2009 en blijft daarna stabiel. In de jaren van dalende garnalenvisserij (2004 naar 2005 en 2006 tot aan 2009) neemt ook de platvisvisserij af. In de jaren van groeiende garnalenvisserij (2010 tot aan 2015) blijft de platvisvisserij juist stabiel.

Ook een verdere analyse van de patronen in de inspanning per hectare visgrond spreekt deze hypothese tegen. Het oppervlak aan visgrond in de Voordelta is door het instellen van het BBG met $30 \%$ afgenomen (zie Appendix 4 voor de berekening). Dit kan een toenemende drukte in het resterende gebied van de Voordelta vanaf 2008 tot gevolg hebben gehad: de visserij-inspanning neemt af, maar de hoeveelheid beschikbare visgrond ook. Echter, de hoeveelheid inspanning per hectare visgrond in 2009 en 2010 is lager dan in 2006 en 2007, voor zowel de platvis- als garnalenvisserij (zie Appendix 4). De drukte in de Voordelta lijkt dus afgenomen te zijn.

Ook de vissers geven in de interviews niet aan dat toenemende drukte meespeelde in het besluit minder in de Voordelta te vissen (hoofdstuk 7).

Conclusie: Toenemende drukte door de garnalenvisserij rondom 2008 speelde geen rol. 
(iii) Door het verdwijnen van visgronden zijn de platviskotters vanaf 2008 buiten de Voordelta gaan vissen.

Het oppervlak aan visgrond wat betreft platvis in de Voordelta is door het instellen van het BBG met $30 \%$ afgenomen (zie ii). Als er geen displacement plaatsvindt, kan verwacht worden dat de inspanning evenredig afneemt. De inspanning per jaar is echter met $58 \%$ afgenomen (van gemiddeld 3910 visuren in 2006-2007 naar 1630 visuren in 2008-2009, zie Appendix 4). Dit is meer dan op basis van het oppervlak bevisbaar visgronden te verwachten is. Displacement naar de rest van de Voordelta lijkt dus geen dominante rol te spelen, en de afname van visserij in het gebied zou dus deels verklaard kunnen worden door het verlies aan visgronden.

In de interviews geven de vissers echter aan dat het verlies aan visgronden geen rol heeft gespeeld (hoofdstuk 7).

Een additioneel potentieel proces is dat het verminderde en gefragmenteerde oppervlak aan beschikbare visgronden, visserij in de Voordelta onaantrekkelijk heeft gemaakt; de overgebleven stukken visgrond zijn niet praktisch rendabel te bevissen, omdat de vissers verder moeten stomen dan voorheen, om bij nabijgelegen visgronden te komen.

In de interviews geven vissers aan dat dit meespeelt: de Voordelta is sinds de Maasvlakte2 en het BBG minder aantrekkelijke visgrond, omdat het gebied te gefragmenteerd is (hoofdstuk 7). Kotters maken bij de meeste visreizen gebruik van een groter gebied dan alleen de Voordelta. Door de 'obstakels' (MV2 en BBG) moet nu veel gestoomd worden voordat andere visgronden bereikt worden.

\section{Conclusie: Door het verdwijnen van visgrond en de fragmentatie van het gebied zou de platvisvisserij kunnen zijn afgenomen.}

(iv) Met het vooruitzicht van de toekomstige instelling van het Bodembeschermingsgebied, zijn de vissers eerder dan 2008 buiten de Voordelta gaan vissen.

Vissers hebben tijd nodig om een gebied te leren kennen en de beste visgronden te ontdekken. Met de onzekerheid en uiteindelijk het vooruitzicht van het BBG zouden vissers al in de paar jaren voorafgaand aan de instelling in andere gebieden zijn gaan vissen.

De gegevens ondersteunen deze hypothese niet. De verwachting zou zijn dat de vissers maximaal een klein aantal jaar eerder hun gedrag zouden hebben aangepast. Juist in de paar jaar voorafgaand aan 2008 (2006, 2007) vindt er geen opvallende verandering in de hoeveelheid inspanning van de platviskotters in de Voordelta te zijn (Figuur 0-15).

Ook geven de vissers zelf in de interviews niet aan dat dit een rol heeft gespeeld (hoofdstuk 7). Alleen een informant geeft dit als potentiele reden aan dat de discussie rond 2002 begon, dezelfde periode waarin de visserij-inspanning begint met afnemen (Figuur 0-31).

Als deze informant gelijk heeft, dan zijn de vissers dus sinds 2002 sterk gaan verminderen in hun Voordelta-visserij, en zijn ze dit naderhand vergeten, of is dit onbewust gebeurd. Het is onwaarschijnlijk dat geen van de vissers zich hiervan bewust zou zijn geweest.

Conclusie: Het vooruitzicht van de toekomstige instelling van het

Bodembeschermingsgebied lijkt geen rol te hebben gespeeld in de paar jaren voorafgaand eraan. Het is niet uit te sluiten dat het vooruitzicht al vanaf 2002 een rol speelt, maar ook dit lijkt niet waarschijnlijk. 


\section{Conclusies}

Boomkorvisserij in de Voordelta is een complex gebeuren, waarbij schepen meestal vissen met meerdere tuigen, op meerdere doelsoorten en vanuit meerdere havens. Een groot deel van de kotters die op platvis vist in de Voordelta vist ook - en vooral - op garnaal in de Voordelta. Bovendien zijn geen van de kotters gespecialiseerd in de Voordelta maar is dit slechts een klein deel van hun visgebied.

Dit rapport heeft twee hoofdvragen (zie hoofdstuk 1.2). Hoofdvraag 2 is wat de oorzaken zijn van de verminderde platvisvisserij in de Voordelta. Op basis van de beschikbare gegevens over de onttrekking door boomkorkotters kan het volgende geconcludeerd worden:

De grootste afname in de platvisvisserij lijkt Noordzeebreed plaats te vinden: de platviskotters gaan in hun hele visgebied minder vissen over de jaren 2004-2015 heen. Binnen de Voordelta lijkt er wel een extra grote afname te zijn. Echter, het begin van deze Voordelta-specifieke afname lijkt eerder ingezet dan in de periode 2004-2015 en heeft waarschijnlijk niet te maken met het instellen van het BBG. Wel lijkt rond 2008/2009 de visserij-inspanning in de Voordelta te stabiliseren op een laag en basaal niveau. Andere redenen uitgesloten hebbende, is het mogelijk dat de komst van het BBG en de Maasvlakte2 hier een rol bij hebben gespeeld. Het instellen van het BBG kan dus een kleine, aanvullende rol hebben gespeeld in de afname van de bodemberoerende visserij in het gebied.

Hoofdvraag 1 is; hoe groot was de onttrekking van vis en garnaal door de platvis- en garnalenkotters voor en na de instelling van het BBG en wat is het effect van deze onttrekking geweest op de omvang van de commerciële bestanden? De volgende schattingen zijn gemaakt:

De impact van de platviskotters in termen van inspanning en onttrekking van biomassa (vis en benthos) was in 2004 al relatief klein, en is sterk afgenomen tussen 2004 en $2015^{17}$. Tussen T0 en T1 is de jaarlijkse onttrekking meer dan gehalveerd van 851 naar 322 ton biomassa en tussen T1 en T2 nog verder afgenomen naar 244. De onttrekking door de garnalenvisserij is veel groter dan van de platvisvisserij. Ook is deze onttrekking juist toegenomen in de periode 2006-2015. Tussen T0 (2006-2007) en T1 (2008-2011) is de onttrekking iets afgenomen van 1928 naar 1694 ton biomassa, maar in T2 (2012-2015) neemt deze weer sterk toe naar 2682. Opgeteld over beide typen visserij is de onttrekking van biomassa van T0 naar T1 sterk afgenomen van 2779 ton naar 2016 ton maar in T2 juist weer sterk toegenomen naar 2926 ton.

Wat betreft de impact van de visserij op het ecosysteem in de Voordelta, kan geconcludeerd worden dat de impact van de bodemberoerende visserij op de schol en tong bestanden waarschijnlijk consistent is afgenomen over de drie periodes heen. Voor wijting is geen duidelijke trend te zien (afname van T0 naar T1 en toename naar T2). De aanname hierbij is dat de biomassaontwikkelingen van deze soorten in de Voordelta gelijk zijn als die bestandwijd (i.e., op Noordzeeschaal en hoger). De impact op de garnaal die leeft in de Voordelta is afgenomen van T0 naar T1 maar toegenomen in T2. Voor de overige commerciële bestanden bestaan geen goede bestandsschattingen en kon de vraag dus niet benaderd worden.

\footnotetext{
${ }^{17}$ Discards van benthos anders dan garnaal zijn niet meegenomen hierin.
} 


\section{Literatuur}

Catchpole, T. L., A. S. Revill, J. Innes, and S. Pascoe. 2008. Evaluating the efficacy of technical measures: a case study of selection device legislation in the UK Crangon crangon (brown shrimp) fishery. Ices Journal of Marine Science 65:267-275.

Eigaard, O. R., F. Bastardie, M. Breen, G. E. Dinesen, N. T. Hintzen, P. Laffargue, L. O. Mortensen, J. R. Nielsen, H. C. Nilsson, F. G. O'Neill, H. Polet, D. G. Reid, A. Sala, M. Skold, C. Smith, T. K. Sorensen, O. Tully, M. Zengin, and A. D. Rijnsdorp. 2016. Estimating seabed pressure from demersal trawls, seines, and dredges based on gear design and dimensions. Ices Journal of Marine Science 73:27-43.

Glorius, S. T., J. A. M. Craeymeersch, T. v. d. Hammen, A. D. Rippen, J. Cuperus, B. E. v. d. Weide, J. Steenbergen, and I. Y. M. Tulp. 2015. Effecten van garnalenvisserij in Natura 2000 gebieden. Wageningen Marine Research, Den Helder.

ICES. 2015a. 6.3.7 Dab (Limanda limanda) in Subarea IV and Division IIIa (North Sea, Skagerrak and Kattegat). ICES Advice on fishing opportunities, catch, and effort. Greater North Sea and Celtic Seas Ecoregions. http://www.ices.dk/sites/pub/Publication\%20Reports/Advice/2015/2015/dabnsea.pdf.

ICES. 2015b. 6.3.8 Flounder (Platichthys flesus) in Subarea IV and Division IIIa (North Sea, Skagerrak and Kattegat). ICES Advice on fishing opportunities, catch, and effort. Greater North Sea and Celtic Seas Ecoregions. http://www.ices.dk/sites/pub/Publication\%20Reports/Advice/2015/2015/flensea.pdf.

ICES. 2015c. Report of the Working Group on Crangon Fisheries and Life History (WGCRAN). http://ices.dk/sites/pub/Publication\%20Reports/Expert\%20Group\%20Report/SSGEPD/2015/01\%20 WGCRAN\%20-

\%20Report\%20of\%20the\%20Working\%20Group\%20on\%20Crangon\%20Fisheries\%20and\%20Life $\% 20$ History.pdf.

ICES. 2016. ICES Special Request Advice. OSPAR request for further development of fishing intensity and pressure mapping.

ICES. 2017. Report of the Working Group on the Assessement of Demersal Stocks in the North Sea and Skagerrak (WGNSSK). ICES Advice on fishing opportunities, catch, and effort. Greater North Sea and Celtic Seas Ecoregions. ICES CM 2016/ACOM: 14.

Jongbloed, R. H., N. T. Hintzen, M. A. M. Machiels, and A. S. Couperus. 2014. Nadere effecten analyse staandwantvisserij - bruinvis in Natura 2000 gebied Vlakte van Raan in Wageningen Marine Research, ed.

Prins, T. C., G. H. van der Kolff, A. R. Boon, J. Reinders, C. Kuijper, G. Hendriksen, H. Holzhauer, V. T. Langenberg, J. A. M. Craeymeersch, I. Y. M. Tulp, M. J. M. Poot, H. C. M. Seegers, and J. Adema. 2014. PMR Monitoring natuurcompensatie Voordelta. Eindrapport 1e fase 2009-2013 in Deltares, ed. Deltares.

Schellekens, T., V. Escaravage, K. Goudswaard, M. van Asch, and J. A. M. Craeymeersch. 2014. Garnalenvisserij experiment Voordelta in I. R. C154/14, ed.

Tulp, I. Y. M., C. Chen, H. Haslob, K. Schulte, V. Siegel, J. Steenbergen, A. Temming, and M. Hufnagl. 2016. Annual brown shrimp (Crangon crangon) biomass production in NOrthwestern Europe contrasted to annual landings. Ices Journal of Marine Science doi:10.1093/icesjms/fsw141.

Tulp, I. Y. M., T. C. Prins, N. S. H. Tien, J. A. M. Craeymeersch, and M. T. van der Sluis. 2015. Monitoringsen onderzoeksplan vervolg Monitoring PMR-NCV.

van Keeken, O. A., M. van Hoppe, R. E. Grift, and A. D. Rijnsdorp. 2007. Changes in the spatial distribution of North Sea plaice (Pleuronectes platessa) and implications for fisheries management. . J. Sea Res. 57:187-197. 


\section{Appendix 1 Methodiek}

\section{A1.1 Experiment garnalenvisserij Voordelta 2010-2012}

\section{Opzet}

$\mathrm{Bij}$ de instelling van het BBG is afgesproken om onderzoek te doen naar de specifieke effecten van garnalenvisserij op de bodemhabitats in de Voordelta. Daarom is hier in 2010-2012 onderzoek naar gedaan. De kernvraag was of de beoogde natuurcompensatie gehaald kan worden bij voortzetting van de garnalenvisserij.

In elk van zes proefvakken (Figuur A1.1) zijn twee deelgebieden onderscheiden, waarvan er één experimenteel bevist werd. Het andere moest jaar rond onbevist (=controle) blijven (Schellekens et al 2014). Bij de opzet is rekening gehouden met een analyse van de punten op proefvak-, deelproefvaken monsterpuntniveau. Bij de start van het onderzoek is uitgegaan van een drie jaar durende experimentele bevissing. Uitspraken over effect van visserij zijn dus mogelijk over de looptijd van het experiment. Vergelijkingen tussen bevist en onbevist vormden de basis voor het onderzoek. De experimentele bevissing werd uitgevoerd door een garnalenvisser, en was afgestemd op de gangbare visserijdruk (vastgesteld i.s.m. de sector). Aan de uitvoering van deze experimentele visserij is qua visgedrag en vistuig geen verandering vanuit het onderzoek toegevoegd en de bevissing is daarmee uitgevoerd alsof het een gewone commerciële visserij betrof. De afstelling van de twee $9 \mathrm{~m}$ brede netten is door de visser steeds aangepast aan de lokale situatie (door bv. bijstellen van de klossen), zoals hij normaal ook zou doen. Bevissing vond zes maal per jaar plaats, tussen mei en november. De bevissing heeft plaatsgevonden in 2010, 2011 en 2012. In de te bevissen gebieden werden telkens 6 trekken uitgevoerd in de lengterichting van het proefvak, over de hele lengte van het onderzoeksgebied.

Alle vangsten zijn per trek aan boord onmiddellijk na het aan dek halen uitgezocht, alle organismen zijn gedetermineerd en geteld. Van iedere vangst is een foto gemaakt. Van de vissen is de lengte bepaald, en via een lengte-gewichtregressie de biomassa.

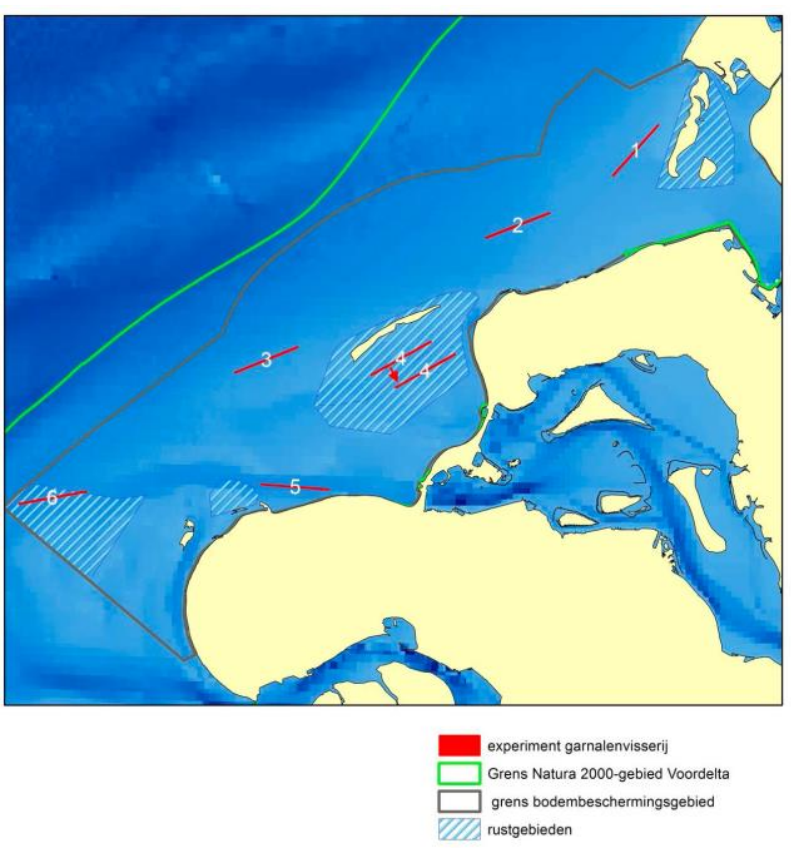

Figuur A1.1. Ligging van de 6 proefvakken in het bodembeschermingsgebied bij de start van het onderzoek. Proefvak 4 is in de loop van het onderzoek verplaatst naar het zuidoosten 


\section{Vangstregistratie garnalennet}

De vangst (vis en bodemdieren) is per trek vastgesteld aan boord. Het gebruikte garnalennet ( $9 \mathrm{~m}$ breed) is van het type met een zeeflap waarbij grote vis wordt gescheiden van de kleine en waarbij een deel van de kleinere grote soorten door de grofmazige netten kunnen ontsnappen.

Voor dit onderzoek is de zeeflap in deze bevissing dichtgebonden en de vangst hiervan is aan de totale vangst toegevoegd. De grote fractie is daardoor oververtegenwoordigd in de vangsten, in vergelijking met de vangsten van een commerciële garnalenvisser.

De gehele vangst van deze bevissing is voor elke trek gekarakteriseerd door alle vis en benthos uit beide netten te betrekken in de totale vangst. De totale vangst kan in twee delen worden gescheiden, $\mathrm{nl}$. dat wat door de zeeflap wordt tegengehouden en dat wat in het uiteinde van het fijnmazig garnalen net met een maaswijdte van $22 \mathrm{~mm}$ wordt vastgehouden. Door deze kleine maaswijdte worden er veel vissoorten meegevangen. Om de bijvangst van deze soorten te verminderen zijn garnalenvissers in Nederland verplicht tot het gebruik van een zeeflap. Een zeeflap bestaat uit een grofmazig net (maaswijdte 5-6 cm) voor de ingang van de boomkor, waardoor de grotere vis wordt tegengehouden en kan ontsnappen. Garnalen en kleinere vis worden doorgelaten en verzamelen zich in de staart van het net (Catchpole et al 2008).

De vangst van alle vis en krabben in het bakboord- en stuurboordnet die in de grofmazige zak zit, is volledig geteld. Wanneer er een grote hoeveelheden zeesterren of slangsterren inzitten, is daarvan een deelmonster geteld.

Van de vangst uit het fijnmazige net waar de garnaal in zit, is een deelmonster genomen, bijv. 20 liter. Daarnaast wordt de rest uitgestort en doorzocht op zeldzame vangsten. Deze zijn buiten het deelmonster om geregistreerd. In het deelmonster zijn alle soorten gescheiden en indien in grote aantallen van gelijke lengte is daarvan opnieuw een deelmonster genomen voor lengtemeting. Dit laatste geldt vrijwel altijd voor garnalen waarvan er rond de 50 stuks worden gemeten. Krabben, heremiet kreeften, zeesterren en schelpdieren zijn geteld maar niet gemeten.

De gegevens van beide bronnen zijn samengevoegd. De vangst door de zeeflap is daarmee niet meer te onderscheiden van de rest van de vangst. 


\section{A1.2 Interviews met Voordelta vissers}

\section{Doel}

We hebben met een selectie van de vissers die in de Voordelta actief zijn geweest interviews gehouden. De vissers zijn gekozen uit een groep vissers die geselecteerd waren omdat ze tussen 2004 en 2007 platvisvisserij in de Voordelta hebben bedreven (zie sectie 9.1 .3 over de selectie).

We zijn in de interviews met name geïnteresseerd om van de vissers te horen welke oorzaken zij zien voor een afname van platvisvisserij in de Voordelta en om een begrip te krijgen van hoe de vissers die actief waren op de Voordelta voor 2008, de invoering van het BBG en de rustgebieden beleefd hebben. Ten tweede verwachten we uit de gesprekken nuttige informatie te halen die kan dienen als input voor de kwantitatieve analyse. Uit de resultaten van de interviews komen naar verwachting nieuwe hypotheses naar voren. Deze hypotheses zijn daarna mogelijk te testen aan de hand van de visserijdata. Het is vaak het probleem in de data analyses dat men niet weet naar welke patronen gezocht moet worden, de interviewresultaten kunnen daarbij helpen.

\section{Selectie vissers}

Uit de data is een selectie gemaakt van 72 vissers die tussen 2004 en 2007 platvisvisserij in de Voordelta hebben bedreven.

Respondenten worden voor dit onderzoek niet random geselecteerd en zullen daarmee geen representatieve steekproef voor de gehele populatie zijn. Ten eerste is het aantal interviews te klein om iets over de gehele populatie te zeggen. Ten tweede is het van belang dat de interviews relevante en rijke informatie genereren. Daarom zal juist actief gepoogd worden, respondenten te vinden die kennis hebben van de Voordelta door hun eigen visserijgedrag en die ook een overzicht hebben van de hele visserij in de regio.

Het doel was initieel om acht vissers te interviewen, dat zijn er uiteindelijk 6 geworden (naast 2 interviews met informanten). Toen eind 2016 een tussentijdse analyse gedaan werd, is besloten om in plaats van meer vissers individueel te interviewen, een focused group sessie te houden met een grotere groep vissers. Deze sessie is gehouden op 7 april (zie hieronder).

\section{Interviews}

Van tevoren wordt niet precies vastgelegd wie er zal worden geïnterviewd. Enerzijds is dit niet mogelijk omdat we van tevoren niet kunnen weten wie aan een interview zal meewerken. Anderzijds biedt dit flexibiliteit om door middel van snowball sampling geschikte respondenten te vinden. Snowball sampling betekent dat nieuwe respondenten gekozen worden op aanraden van eerdere respondenten of via andere informanten.

De eerste vier vissers die wel van tevoren geselecteerd worden om te benaderen zijn:

- Een visser uit ons netwerk die belangrijke bestuurlijke activiteiten ontplooit in deze regio. Gezien de bestuurlijke ervaring verwachten we dat deze visser overzicht heeft van de gehele visserij in de Voordelta.

- Drie vissers die tussen 2004 en 2008 een groot deel van hun totale visserij-inspanning in de Voordelta uitvoerden en die in vergelijking tot andere vissers, een substantieel aantal zeedagen met de boomkor hebben gevist. De verwachting is dat deze vissers, gezien hun ruime ervaring op de Voordelta, inzicht hebben over de ontwikkeling van de boomkorvisserij en beweegredenen van boomkorvissers om daar wel of niet te vissen.

De laatste twee vissers werden aangeraden door de andere respondenten om mee te praten. Er waren meer vissers aangeraden, maar daarmee kwam na herhaalde pogingen geen contact tot stand. 


\section{Focused group}

Nadat een eerste analyse was gedaan op basis van 6 interviews met vissers en 2 met informanten, is besloten om de rest van de tijd gealloceerd voor interviews te gebruiken om een focused group te houden met een grotere groep voordelta vissers en visserijvertegenwoordigers. Hiervoor zijn 2 redenen. Ten eerste omdat we ons ervan bewust zijn dat je met 8 interviews, die a-select gekozen zijn, je geen uitspraken kunt doen voor de hele visserij, terwijl dit wel een vraag is die leeft. Ten tweede werd er ook door vissers gevraagd om de resultaten tussentijds terug te koppelen en de voormannen erbij te betrekken.

Tijdens die FG zijn de eerste resultaten van het onderzoek gepresenteerd, waarbij een combinatie wordt gemaakt van de kwantitatieve en kwalitatieve data (interview gegevens). Er is een verslag gemaakt van de discussie. De belangrijkste vraag van de onderzoekers voor de vissers was: 'Waarom is de platvisvisserij zoveel harder afgenomen in de Voordelta (VD) dan elders?'.

\section{Semi gestructureerde interviews}

Vissers en sleutelfiguren zullen geïnterviewd worden door middel van semi-gestructureerde interviews. Deze manier van interviewen is een flexibele vorm waarbij de interviewer zorgt dat een aantal onderwerpen aan bod komt. Dit gebeurt niet noodzakelijk middels een vastliggende vraagformulering of in een bepaalde volgorde. De respondent krijgt alle tijd om te antwoorden en de mogelijkheid bestaat om dieper in te gaan op die antwoorden (Bryman, 2008: 438). Door de interviews niet volledig in te kaderen verloopt het interview in de vorm van het gesprek en er bestaat ruimte voor de respondent om onderwerpen op te brengen die relevant kunnen zijn maar die de interviewer niet voorzien heeft. Nieuwe thema's kunnen in een volgend interview, maar met een andere visser, weer meegenomen worden. De hier gepresenteerde vragenlijst is dus een richtlijn, gaandeweg het onderzoek kunnen er vragen aan worden toegevoegd en de exacte formulering kan afwijken. De inspanningspatronen van de platvisvissers in de Voordelta zijn zeer divers. Niet alle schepen hebben in alle jaren gevist tussen 2004 en 2014, de afhankelijkheid van de Voordelta verschilt per visser en de schepen laten uiteenlopende patronen van visserijinspanning in de Voordelta per jaar zien. Daarom is het niet mogelijk om met acht respondenten een representatieve steekproef voor het geheel te nemen. Het patroon van de één lijkt niet op dat van de ander, dus de individuele beweegredenen zullen naar verwachting ook verschillen. Om deze reden zal gepoogd worden vissers te spreken die een overzicht hebben van de regionale visserij, die behalve over hun eigen visserijgedrag, ook iets kunnen zeggen over het gedrag van de regionale vloot om zo te achterhalen welke overwegingen samen geleid hebben tot de afnemende visserijinspanning met de boomkor in de Voordelta.

Om tot een goed begrip te komen van de overwegingen van vissers om wel of niet in de Voordelta te vissen, zullen ook vragen gesteld worden naar de context waarbinnen visserijkeuzes gemaakt worden. Zoals: hoe de visser het instellen van het BBG en de aanleg van de Maasvlakte2 heeft ervaren. Om te bevorderen dat vissers openlijk praten zullen zij in het onderzoeksrapport geanonimiseerd worden.

Wanneer daar toestemming voor wordt verleend door de respondent worden interviews opgenomen, zodat ze daarna in detail teruggeluisterd kunnen worden. Wanneer ze geen toestemming geven, worden aantekeningen bijgehouden en wordt het interview direct na het interview uitgewerkt wanneer de herinnering nog vers is.

De interviews zullen op inductieve wijze worden geanalyseerd. Dat wil zeggen dat van tevoren niet alle thema's vast staan waarnaar gezocht zal worden in de interviews. De interviews zullen veelvuldig gelezen en herlezen worden om patronen te herkennen en belangrijke thema's om op basis hiervan te construeren welke beweegredenen achter de afgenomen visserijinspanning zitten.

De analyseresultaten worden gepresenteerd in een onderzoeksverslag en worden opgenomen in het hoofdstuk over de oorzaken achter de geobserveerde visserijpatronen in het eindrapport van dit deelproject. 


\section{Resultaten}

Dit onderzoek beoogd niet om een representatief beeld te genereren van de het visserijgedrag van vissers in de Voordelta. Daarvoor is de onderzochte populatie te klein en de populatie is niet willekeurig geselecteerd.

Deze kwalitatieve manier van onderzoek doen heeft, in tegenstelling tot een kwantificeerbare enquête, het voordeel dat het een rijke data oplevert over de beleving van individuen uit de onderzoekspopulatie en over de overwegingen zij maken op basis waarvan zij handelen (Bryman, 385 - 387). Doordat het rijke data oplevert en ruimte laat voor onvoorziene uitkomsten is deze methode is geschikt voor een verkennend onderzoek naar een nieuw onderwerp in een nieuwe omgeving als hier het geval is.

De resultaten zullen niet kwantitatief worden weergegeven. Dit wel doen, zou impliceren dat het van belang is dit te doen, maar het zegt weinig. Ten eerste, zoals reeds aangegeven, is de onderzochte populatie te klein om iets over de gehele populatie te zeggen en ten tweede zijn de interviews niet één op één vergelijkbaar omdat ze een verschillend verloop kunnen hebben.

De resultaten zullen wel gebruikt worden voor het ontwikkelen van nieuwe kennis en inzichten over displacement, om een begrip te krijgen van hoe vissers die in de Voordelta actief waren de invloed van het BBG op hun visserij hebben beleefd en als inbreng voor de kwantitatieve data-analyse door de visserij-onderzoekers.

Uit de resultaten van de interviews en de focused group komen naar verwachting nieuwe hypotheses naar voren. Deze hypotheses zijn daarna mogelijk te testen aan de hand van de visserij-data. Het is vaak het probleem in de data analyses dat men niet weet naar welke patronen gezocht moet worden, de interviewresultaten kunnen daarbij helpen.

Vragenlijst

- $\quad$ Met welke tuigen vist u? Op welke doelsoorten en bijvangstsoorten? (soorten waar de visser zich op richt tijdens zijn visserijactiviteiten) Hoe lang bent u schipper op dit schip?

- Kunt u vertellen over uw visserij op de Voordelta? Welke jaren viste u daar? In welk seizoen? Waarom vist(e) u daar met de boomkor? Welke doel- en bijvangstsoorten? Waar in de Voordelta? (aanwijzen op afb. 1)

- Heeft $\mathrm{u}$ in de Voordelta ook met andere tuigen gevist? Welke, wanneer? Waarom?

- Is de Voordelta een gebied waar iedere visser wel kan vissen of heb je er veel kennis en ervaring nodig? Heb je er specifieke tuigaanpassingen voor nodig?

- Viste u samen op met bepaalde andere vissers? Wie?

- Welke vissers zaten daar nog meer? Schatting hoeveel? Schatting hoeveel buitenlandse vissers?

- Hoe zag/ziet uw zoek-/ vispatroon er uit in de Voordelta? (waar begon u, hoe ging u te werk)

- Hoe was het visaanbod in de Voordelta, door de jaren, door het seizoen?

- Is de visstand naar uw mening veranderd en zo ja hoe dan?

- Viste u ook in wat nu het BBG is? waarom wel/niet?

- Voor welke vissers was de Voordelta voor 2008 een belangrijke visgrond? Voor welke vissers is de Voordelta nu een belangrijke visgrond? En waarom?

- Kunt u vertellen over uw visserij buiten de Voordelta? Welke tuigen? In welk seizoen? Waar? (laten aanwijzen op kaart) Waarom vist(e) u daar met de boomkor? Welke doel- en bijvangstsoorten?

- Is het gebied/zijn de gebieden buiten de Voordelta een gebied/gebieden waar iedere visser kan vissen of heb je er veel kennis en ervaring nodig?

- Viste u samen op met bepaalde andere vissers? Wie?

- Welke vissers zaten daar nog meer?

- Hoe zag/ziet uw zoekpatroon er uit in de Noordzee?

- Alle plekken waar u met de boomkor op platvis heeft gevist, heeft u een favoriete plek allertijden? Welke, waarom?

- Voor welke visserij is de sluiting van de VD het meest ingrijpend geweest? (algemeen en voor de vissers specifiek) 
- $\quad$ Bent u overgeschakeld op pulsvisserij en zo ja wanneer? Welke overweging leidde daar tot uw beslissing om wel/niet tot puls over te schakelen. Heeft u steun gehad van compensatiegelden MV2?

- We kijken naar het veranderende visserijpatroon van de platvisvisserij met de boomkoor in de Voordelta tussen 2004 en 2015. Kunt u vertellen over de periode 2004 en 2008? Wat waren belangrijke ontwikkelingen voor uw visserij in die tijd en hoe was dat nog eerder, in de jaren 80 en 90 van de vorige eeuw? Wat waren successen? Wat waren problemen?

- Vragen over individuele patroon visserijinspanning met de boomkor. Verschilt per respondent. Bijvoorbeeld: We zien dat u sinds 2004 steeds minder op de Voordelta bent gaan vissen met de boomkor, hoe komt dat? Wat bent $u$ in de plaats gaan doen? (bij verandering van gebied:) Koste het moeite/tijd/geld om op een andere plek te gaan vissen? Heeft dit de verhoudingen met andere vissers veranderd? Bijv. andere concurrenten andere concullega's? (bij verandering tuig:) wat waren uw redenen om met dit tuig te gaan vissen?

- Wij zien tussen 2004 en 2009 een afname van het totaal aantal dagen dat er door boomkorvissers in de Voordelta wordt gevist. Heeft u een verklaring voor deze totale afname? (Doorvragen: we zien zowel op de Noordzee als in de Voordelta een afname van het aantal schepen. Op de Noordzee blijft inspanning per schip gelijk, in de Voordelta niet, wat is uw verklaring?) (na open vraag suggesties toetsen: brandstofprijs? Visaanbod?)

- In 2008 is het BBG gesloten voor boomkorvisserij $>260$ PK. Kunt u vertellen wat uw mening is over deze sluiting?

- Hoe had de visserij eruit gezien zonder het BBG? In hoeverre heeft deze maatregel de boomkorvisserij in de regio veranderd? Op welke manier? Zijn er mensen hard getroffen? Wie? Op welke manier? Hebben er mensen geprofiteerd? Wie? Hoe was het hen vergaan als het BBG niet was gesloten?

- Heeft u de indruk dat het gebied veranderd is sinds de instelling van het BBG? Andere soorten? Meer/ minder van bepaalde soorten?

- Kunt u zich voorstellen dat de toegenomen visserij op garnalen in het BBG een gevolg is van het wegblijven van de grote boomkor vissers?

- Wat is naar uw mening het effect van een garnalenkor (rolpees, klossenpees) en een traditionele boomkor op de bodem en het bodemleven?

- Kunt u visserijmaatregelen noemen die ingrijpender zijn dan het BBG? Welke? Waarom?

- Kunt u visserijmaatregelen noemen die minder ingrijpend zijn dan het BBG? Welke? Waarom?

- Als u de genoemde maatregelen incl. BBG een rapportcijfer mag geven, welke zou dat zijn? Wat is uw motivatie voor het cijfer?

- Als u het compensatiefonds een rapportcijfer mag geven, welke zou dat zijn? wat is uw motivatie voor dit cijfer?

- Heeft u de indruk dat het BBG zinvol is? warom wel/niet?

- Heeft u gebruik gemaakt van het compensatiefonds? Op welke manier?

- In 2008 is ook de aanleg van de Maasvlakte 2 begonnen. Kunt u vertellen wat uw mening hierover is?

- In hoeverre heeft MV2 mensen in de visserijsector getroffen? Wie zijn het hardst getroffen? Wie hebben geprofiteerd? Hoe had de visserij eruit gezien zonder MV2?

- Heeft u de indruk dat het gebied veranderd is sinds de instelling van het BBG? Andere soorten? Meer minder van bepaalde soorten? Verandering in bodemsamenstelling of waterdiepte?

- Kunt u veranderingen door maatregelen, economische omstandigheden of in natuurlijke omstandigheden noemen die ingrijpender op de de visserij zijn dan de MV2? Welke? Waarom?

- Kunt u veranderingen noemen die minder ingrijpend zijn dan de MV2? Welke? Waarom?

- In de Voordelta vissen vissers uit verschillende havens (zie afb. 3). In hoeverre kennen de vissers uit deze verschillende havens elkaar? Hoe zijn de verhoudingen tussen vissers uit verschillende havens? Kun je stellen dat de Voordelta voor sommige van deze havens belangrijker is dan voor andere?

- Als u morgen weer in de Voordelta zou mogen vissen zou u dat doen? Indien ja dan: a) liefst met de oude boomkor met wekkerkettingen, b) met de pulskor Waarom?

- Wie moet ik verder spreken om de visserij in de Voordelta beter te begrijpen? 


\section{Appendix 2. Ondersteunende figuren en tabellen}

In deze Appendix zijn de tabellen opgenomen met de gegevens achter de belangrijkste figuren per hoofdstuk. Ze zijn benoemd naar de figuur waar ze bij horen. Ook zijn ondersteunende figuren opgenomen per hoofdstuk.

\section{Hoofdstuk 2}

Tabel 0-5 Totale aanlandingen (in ton $/ 1000 \mathrm{~kg}$ ) van alle actieve visserijen uit de Voordelta tussen 20042015.

\begin{tabular}{|l|l|l|l|}
\hline Soort & ton & Soort & ton \\
\hline Garnaal & 10454.9 & Brasem & 2.1 \\
\hline Zwaardschede & 9000.5 & Steenbolk & 1.6 \\
\hline Bot & 1529.9 & Aal & 1.5 \\
\hline Schar & 895.1 & Mul & 1.2 \\
\hline Tong & 804.7 & Stevige strandschelp & 1.2 \\
\hline Schol & 364.2 & Horsmakreel & 1.1 \\
\hline Kabeljauw & 190.5 & Chinese wolhandkrab & 0.8 \\
\hline Wijting & 123.2 & Fint & 0.8 \\
\hline Tarbot & 35.4 & Zeebaarzen & 0.8 \\
\hline Horsmakrelen & 29.9 & Engraulis & 0.4 \\
\hline Griet & 29.3 & Harder ongespecificeerd & 0.4 \\
\hline Noordzeekrab & 28.5 & Grauwe poon & 0.3 \\
\hline Adriatische steur & 20 & Hondshaai & 0.3 \\
\hline Zeebaars & 18.6 & Pelser & 0.3 \\
\hline Rode poon & 17 & Engelse poon & 0.2 \\
\hline Makreel & 12.6 & Martialia & 0.2 \\
\hline Snoekbaars & 3.2 & Rogachtigen & 0.2 \\
\hline Sprot & 3.1 & Tongschar & 0.2 \\
\hline Zeekreeft & 2.8 & Donkere haai & 0.1 \\
\hline Wulk & 2.6 & Doornhaai & 0.1 \\
\hline Zeekat & 2.6 & Gevlekte rog & 0.1 \\
\hline Loliginidae & 2.5 & overig & 0.1 \\
\hline Spiering & 2.3 & Stekelrog & 0.1 \\
\hline Beenvissen & 2.1 & Tijgerhaai & 0.1 \\
\hline & & & \\
\hline
\end{tabular}




\section{Hoofdstuk 3}

Tabel bij Figuur 0-7. De visserij van de platviskotters in de Voordelta tussen 2004-2015. Totaal \# visuren: aantal visuren dat in totaal gevist is. \# actieve schepen: aantal schepen dat gevist heeft. Gemiddeld \# visuren per actief schip: het gemiddelde aantal visuren van één actief schip.

\begin{tabular}{|c|c|c|c|}
\hline jaar & \# visuren & \# actieve schepen & $\begin{array}{c}\text { gemiddeld \# visuren } \\
\text { per actief schip }\end{array}$ \\
\hline 2004 & 9215 & 44 & 209.4 \\
\hline 2005 & 5642 & 36 & 156.7 \\
\hline 2006 & 3883 & 37 & 105.0 \\
\hline 2007 & 3936 & 29 & 135.7 \\
\hline 2008 & 2822 & 24 & 117.6 \\
\hline 2009 & 2161 & 29 & 74.5 \\
\hline 2010 & 1099 & 26 & 42.3 \\
\hline 2011 & 1663 & 25 & 66.5 \\
\hline 2012 & 1610 & 19 & 84.7 \\
\hline 2013 & 1600 & 17 & 94.1 \\
\hline 2014 & 801 & 18 & 44.5 \\
\hline 2015 & 1705 & 23 & 74.1 \\
\hline
\end{tabular}

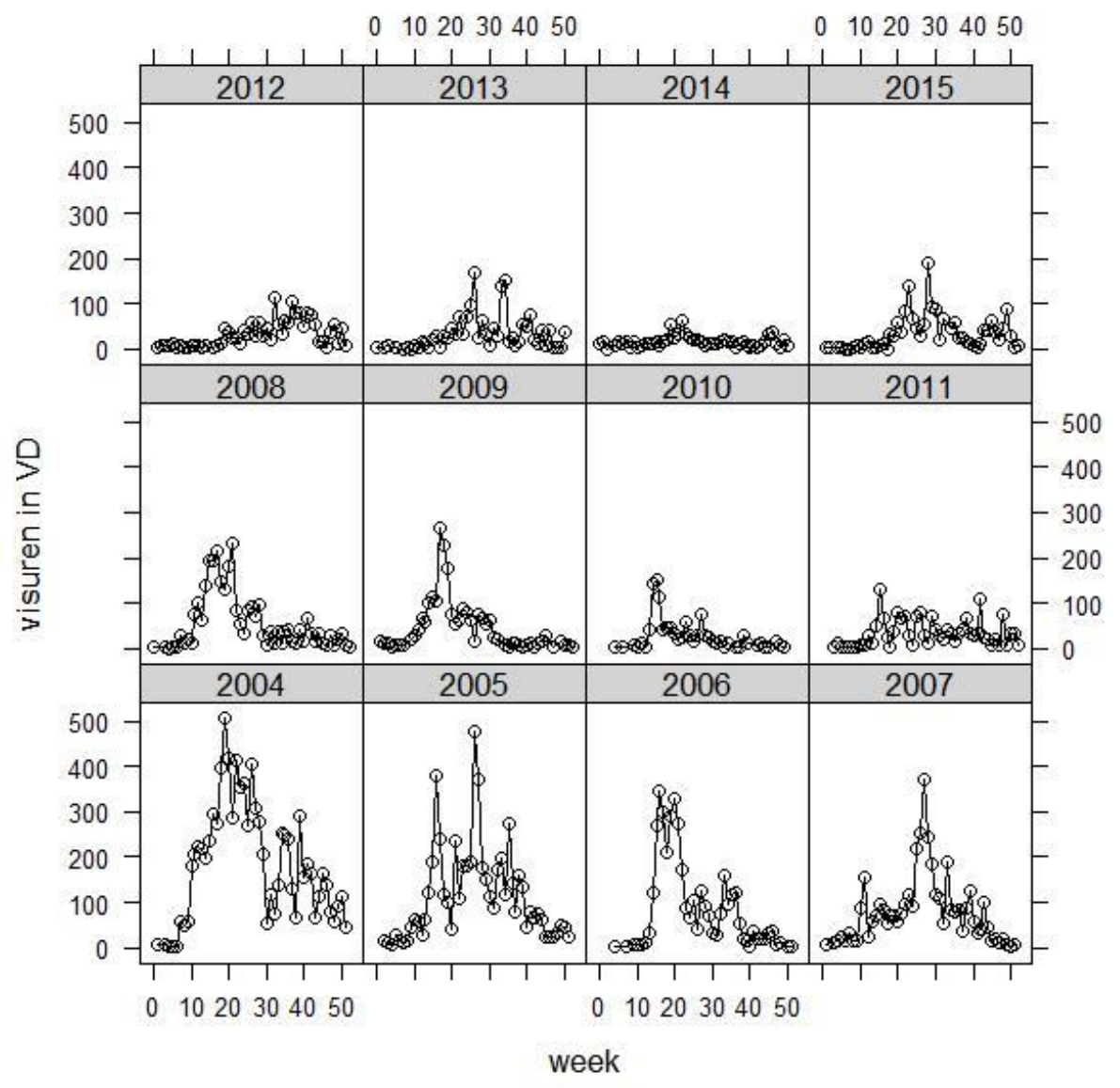

Figuur bij Figuur 0-9 Gemiddelde percentage visuren per week per jaar, voor de platvisvloot in de Voordelta tussen 2004-2015. 
Tabel bij Figuur 0-13 De visserij van de platviskotters die tussen 2004-2015 in de Voordelta actief zijn geweest in de gehele Noordzee. Totaal \# visuren: aantal visuren dat in totaal gevist is. \# actieve schepen: aantal schepen dat gevist heeft. Gemiddeld \# visuren per schip: het gemiddelde aantal visuren van één actief schip.

\begin{tabular}{|c|c|c|c|}
\hline jaar & \# visuren & \# actieve schepen & $\begin{array}{c}\text { gemiddeld \# visuren } \\
\text { per actief schip }\end{array}$ \\
\hline 2004 & 93704 & 44 & 2130 \\
\hline 2005 & 88972 & 44 & 2022 \\
\hline 2006 & 76129 & 39 & 1952 \\
\hline 2007 & 61299 & 34 & 1803 \\
\hline 2008 & 51285 & 31 & 1654 \\
\hline 2009 & 72046 & 41 & 1757 \\
\hline 2010 & 50931 & 32 & 1592 \\
\hline 2011 & 72875 & 34 & 2143 \\
\hline 2012 & 65793 & 23 & 2861 \\
\hline 2013 & 56035 & 20 & 2802 \\
\hline 2014 & 39509 & 23 & 1718 \\
\hline 2015 & 1705 & 23 & 74.1 \\
\hline
\end{tabular}

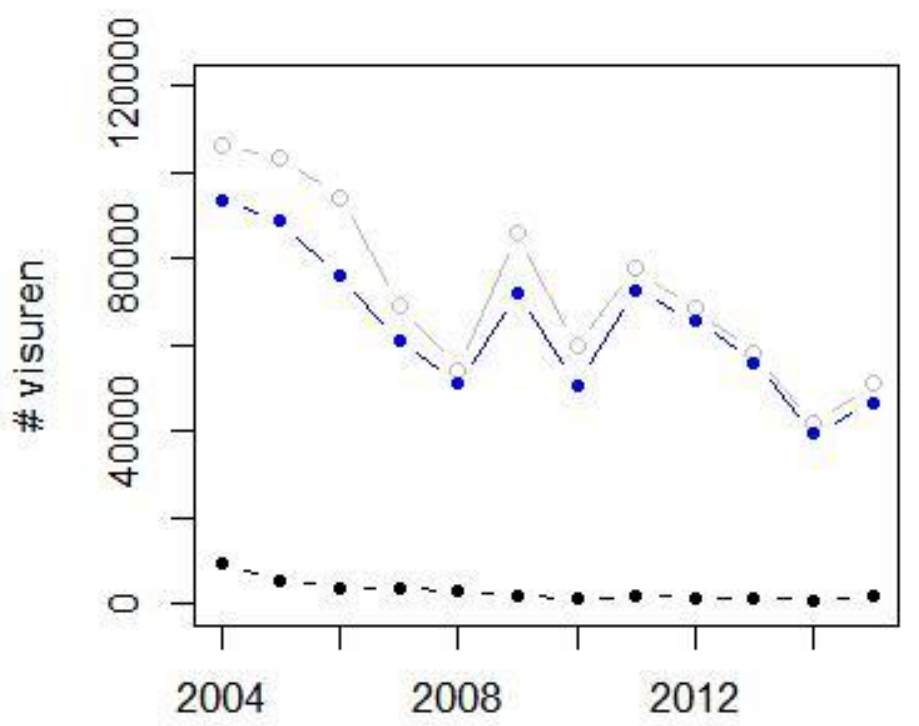

jaar

Figuur bij Figuur 0-13. Het aantal visuren van platviskotters (met 260-300 PK) tussen 2004-2015: van alle Nederlandse platviskotters (grijs) en van de 68 platviskotters die ook in de Voordelta hebben gevist, in de gehele Noordzee (blauw) en in de Voordelta (zwart). 
Tabel bij Figuur 0-18 De visserij van de garnalenkotters in de Voordelta tussen 2004-2015. Totaal \# visuren: aantal visuren dat in totaal gevist is. \# actieve schepen: aantal schepen dat gevist heeft. Gemiddeld \# visuren van actieve schepen: het gemiddelde aantal visuren van één actief schip.

\begin{tabular}{|c|c|c|c|}
\hline jaar & \# visuren & \# actieve schepen & $\begin{array}{c}\text { gemiddeld \# visuren } \\
\text { per actief schip }\end{array}$ \\
\hline 2004 & 10235 & 30 & 341 \\
\hline 2005 & 8485 & 28 & 303 \\
\hline 2006 & 22194 & 32 & 694 \\
\hline 2007 & 17513 & 30 & 584 \\
\hline 2008 & 16319 & 29 & 563 \\
\hline 2009 & 13825 & 30 & 461 \\
\hline 2010 & 14158 & 34 & 416 \\
\hline 2011 & 14268 & 23 & 620 \\
\hline 2012 & 19649 & 27 & 728 \\
\hline 2013 & 20657 & 27 & 765 \\
\hline 2014 & 21087 & 39 & 541 \\
\hline 2015 & 28730 & 40 & 718 \\
\hline
\end{tabular}

Tabel bij Figuur 0-19 De visserij van de garnalenkotters in de Noordzee tussen 2004-2015. Totaal \# visuren: aantal visuren dat in totaal gevist is. \# actieve schepen: aantal schepen dat gevist heeft. Gemiddeld \# visuren van actieve schepen: het gemiddelde aantal visuren van één actief schip.

\begin{tabular}{|c|c|c|c|}
\hline jaar & \# visuren & \# actieve schepen & $\begin{array}{c}\text { gemiddeld \# visuren } \\
\text { per actief schip }\end{array}$ \\
\hline 2004 & 10235 & 30 & 341 \\
\hline 2005 & 8485 & 28 & 303 \\
\hline 2006 & 22194 & 32 & 694 \\
\hline 2007 & 17513 & 30 & 584 \\
\hline 2008 & 16319 & 29 & 563 \\
\hline 2009 & 13825 & 30 & 461 \\
\hline 2010 & 14158 & 34 & 416 \\
\hline 2011 & 14268 & 23 & 620 \\
\hline 2012 & 19649 & 27 & 728 \\
\hline 2013 & 20657 & 27 & 765 \\
\hline 2014 & 21087 & 39 & 541 \\
\hline 2015 & 28730 & 40 & 718 \\
\hline
\end{tabular}




\section{Hoofdstuk 4}

Tabel bij Tabel 0-9. Absolute aanlandingen (ton) van de platviskotters in de Voordelta, per soort en jaar

\begin{tabular}{|c|c|c|c|c|c|c|c|c|c|c|c|c|}
\hline & 2004 & 2005 & 2006 & 2007 & 2008 & 2009 & 2010 & 2011 & 2012 & 2013 & 2014 & 2015 \\
\hline Aal & 0.918 & & 0.113 & & & & & & & & & \\
\hline Beenvissen & 0.184 & 0.322 & & 0.360 & 0.200 & & & & 0.337 & & & \\
\hline Blonde rog & & & & & & & & & 0.193 & 0.563 & & \\
\hline Coregonus & & & & & & & 0.139 & & & & & \\
\hline Engelse poon & 0.462 & & 0.220 & 0.389 & & & & & 0.500 & & & \\
\hline Franse tong & & & & & & & & & & & & 0.456 \\
\hline Grauwe poon & & & & & & & & & 0.155 & 0.112 & & 0.321 \\
\hline Griet & 3.887 & 3.759 & 2.966 & 3.958 & 3.215 & 1.915 & 2.119 & 1.349 & 1.243 & 1.568 & 0.327 & 1.876 \\
\hline Harder ongespecificeerd & 0.500 & & & & & & & & & & & \\
\hline Hondshaai & & 0.142 & 0.429 & 0.467 & 0.174 & & & & 0.429 & 0.553 & & 0.256 \\
\hline Horsmakreel & & & & & & & & & & & 0.874 & 0.645 \\
\hline Horsmakrelen & 1.352 & 1.258 & 0.875 & 1.598 & 2.257 & 1.479 & 0.444 & 0.623 & 0.913 & 0.554 & & \\
\hline Makreel & & & & 0.743 & 2.212 & 0.364 & 0.145 & 0.140 & & & & 0.550 \\
\hline Martialia & & & & & & & & & & 0.239 & 0.850 & 0.528 \\
\hline Mul & 0.185 & 0.720 & 0.180 & & & & & & & & & 0.182 \\
\hline Noordzeekrab & 4.489 & 2.321 & 3.494 & 9.489 & 0.567 & 0.274 & 0.459 & 0.873 & 0.266 & 0.219 & 0.788 & 0.196 \\
\hline Noorse kreeft & & & & & & & & 0.774 & & & 0.950 & \\
\hline Rode poon & 2.354 & 2.639 & 1.473 & 0.887 & 0.563 & 0.728 & 0.298 & 0.335 & 0.667 & 1.572 & 0.211 & 2.377 \\
\hline Rogachtigen & 0.559 & & & & & & 0.750 & & 0.213 & & & \\
\hline Schar & 75.837 & 35.747 & 15.436 & 28.656 & 47.967 & 53.714 & 21.984 & 12.548 & 15.687 & 19.255 & 8.187 & 11.760 \\
\hline Schol & 11.860 & 46.219 & 28.793 & 16.195 & 9.470 & 23.657 & 21.545 & 27.687 & 17.817 & 17.856 & 8.525 & 11.822 \\
\hline Scyliorhinus & & & & & & & & & & 0.882 & & \\
\hline Snoekbaars & & & & 0.650 & & & & & & & & \\
\hline Spiering & & 0.198 & & & & & & & & & & \\
\hline Wulk & 1.162 & 0.269 & 0.870 & & & & 0.333 & 0.388 & 0.126 & 0.596 & 0.963 & 0.650 \\
\hline Zeebaars & 0.213 & 1.312 & 2.125 & 1.467 & 1.512 & 1.323 & 0.223 & 0.382 & 0.169 & 0.220 & 0.332 & 0.136 \\
\hline Zeekat & 0.116 & 0.294 & 0.412 & 0.957 & 0.127 & 0.889 & 0.217 & 0.218 & 0.268 & 0.197 & 0.427 & 0.213 \\
\hline Zeekreeft & & 0.400 & 0.456 & 0.516 & 0.250 & 0.230 & & & & & 0.750 & \\
\hline Zwaardschedes indet. & 0.150 & & & & & & & & & & & \\
\hline Zwaardvis & 0.572 & & & & & & & & & & & \\
\hline Totaal & 172.690 & 895.857 & 441.996 & 459.556 & 384.935 & 483.925 & 26.297 & 221.783 & 217.464 & 331.494 & 151.838 & 35.926 \\
\hline
\end{tabular}


Tabel bij Tabel 0-11. Absolute aanlandingen (ton) van de garnalenkotters in de Voordelta, per soort en jaar

\begin{tabular}{|c|c|c|c|c|c|c|c|c|c|c|}
\hline & 2006 & 2007 & 2008 & 2009 & 2010 & 2011 & 2012 & 2013 & 2014 & 2015 \\
\hline Aal & 0.00 & 0.00 & 0.00 & 0.00 & 0.00 & 0.00 & 0.01 & 0.00 & 0.00 & 0.05 \\
\hline Beenvissen & 0.05 & 0.00 & 0.00 & 0.00 & 0.00 & 0.02 & 0.16 & 0.00 & 0.00 & 0.00 \\
\hline Brasem & 0.00 & 0.00 & 0.00 & 0.00 & 0.00 & 0.00 & 0.15 & 0.00 & 0.00 & 0.00 \\
\hline Chinese wolhandkrab & 0.00 & 0.00 & 0.00 & 0.00 & 0.00 & 0.00 & 0.00 & 0.70 & 0.00 & 0.00 \\
\hline Doornhaai & 0.00 & 0.00 & 0.03 & 0.00 & 0.00 & 0.00 & 0.07 & 0.00 & 0.00 & 0.00 \\
\hline Engraulis & 0.00 & 0.00 & 0.00 & 0.00 & 0.00 & 0.00 & 0.00 & 0.08 & 0.20 & 0.00 \\
\hline Geep & 0.00 & 0.00 & 0.00 & 0.00 & 0.00 & 0.00 & 0.00 & 0.00 & 0.00 & 0.00 \\
\hline Gewone garnaal & 1017.53 & 578.15 & 982.49 & 862.80 & 1005.98 & 811.97 & 750.53 & 880.28 & 1817.94 & 1406.47 \\
\hline Griet & 0.06 & 0.00 & 0.19 & 0.00 & 0.08 & 0.04 & 0.13 & 0.05 & 0.00 & 0.06 \\
\hline Harder ongespecificeerd & 0.00 & 0.00 & 0.00 & 0.00 & 0.00 & 0.00 & 0.01 & 0.00 & 0.00 & 0.00 \\
\hline Kabeljauw & 4.64 & 10.73 & 16.77 & 18.29 & 3.82 & 1.59 & 1.94 & 1.54 & 1.18 & 9.47 \\
\hline Loliginidae & 0.12 & 0.06 & 0.00 & 0.29 & 0.10 & 0.00 & 0.01 & 0.00 & 0.00 & 0.00 \\
\hline Lolliguncula & 0.00 & 0.00 & 0.00 & 0.00 & 0.00 & 0.00 & 0.00 & 0.00 & 0.00 & 0.02 \\
\hline Makreel & 1.33 & 0.00 & 1.61 & 0.15 & 0.00 & 0.00 & 0.31 & 0.11 & 0.00 & 0.15 \\
\hline Martialia & 0.00 & 0.00 & 0.00 & 0.00 & 0.00 & 0.00 & 0.00 & 0.00 & 0.04 & 0.01 \\
\hline Mul & 0.00 & 0.00 & 0.00 & 0.00 & 0.00 & 0.00 & 0.00 & 0.00 & 0.02 & 0.00 \\
\hline Noordzeekrab & 0.05 & 0.08 & 0.52 & 0.07 & 0.99 & 0.50 & 2.11 & 0.63 & 0.32 & 0.10 \\
\hline Rode poon & 0.00 & 0.00 & 0.00 & 0.00 & 0.00 & 0.00 & 0.03 & 0.00 & 0.00 & 0.14 \\
\hline Schar & 32.60 & 24.02 & 20.29 & 39.92 & 39.08 & 43.91 & 40.40 & 31.02 & 40.97 & 51.81 \\
\hline Schol & 0.09 & 0.00 & 0.07 & 0.00 & 0.11 & 0.14 & 0.14 & 0.99 & 0.52 & 0.82 \\
\hline Tijgerhaai & 0.02 & 0.00 & 0.03 & 0.00 & 0.00 & 0.07 & 0.00 & 0.00 & 0.00 & 0.00 \\
\hline Tong & 0.79 & 1.34 & 1.71 & 0.36 & 1.16 & 0.50 & 0.89 & 0.60 & 0.55 & 6.16 \\
\hline Tongschar & 0.00 & 0.00 & 0.00 & 0.00 & 0.00 & 0.00 & 0.00 & 0.00 & 0.00 & 0.00 \\
\hline Wijting & 5.18 & 0.37 & 18.65 & 13.76 & 5.98 & 0.74 & 0.64 & 0.03 & 0.09 & 7.54 \\
\hline Wulk & 0.00 & 0.00 & 0.00 & 0.00 & 0.00 & 0.00 & 0.00 & 0.25 & 0.00 & 0.00 \\
\hline Zeebaars & 0.11 & 0.36 & 0.24 & 0.31 & 0.58 & 0.25 & 0.63 & 0.33 & 0.00 & 0.20 \\
\hline Zeebaarzen & 0.00 & 0.00 & 0.00 & 0.00 & 0.00 & 0.00 & 0.00 & 0.80 & 0.00 & 0.00 \\
\hline Zeekat & 0.02 & 0.00 & 0.00 & 0.00 & 1.22 & 0.00 & 0.02 & 0.00 & 0.00 & 0.00 \\
\hline Zeekreeft & 0.03 & 0.00 & 0.00 & 0.00 & 0.00 & 0.00 & 0.03 & 0.02 & 0.00 & 0.33 \\
\hline Totaal & 1096.76 & 639.69 & 1072.65 & 962.01 & 1080.10 & 879.87 & 813.12 & 923.99 & 1869.71 & 1495.94 \\
\hline
\end{tabular}




\section{Hoofdstuk 5}

Tabel bij Tabel 0-12. Geschatte absolute visdiscards (ton) van platviskotters in de Voordelta, per soort en jaar

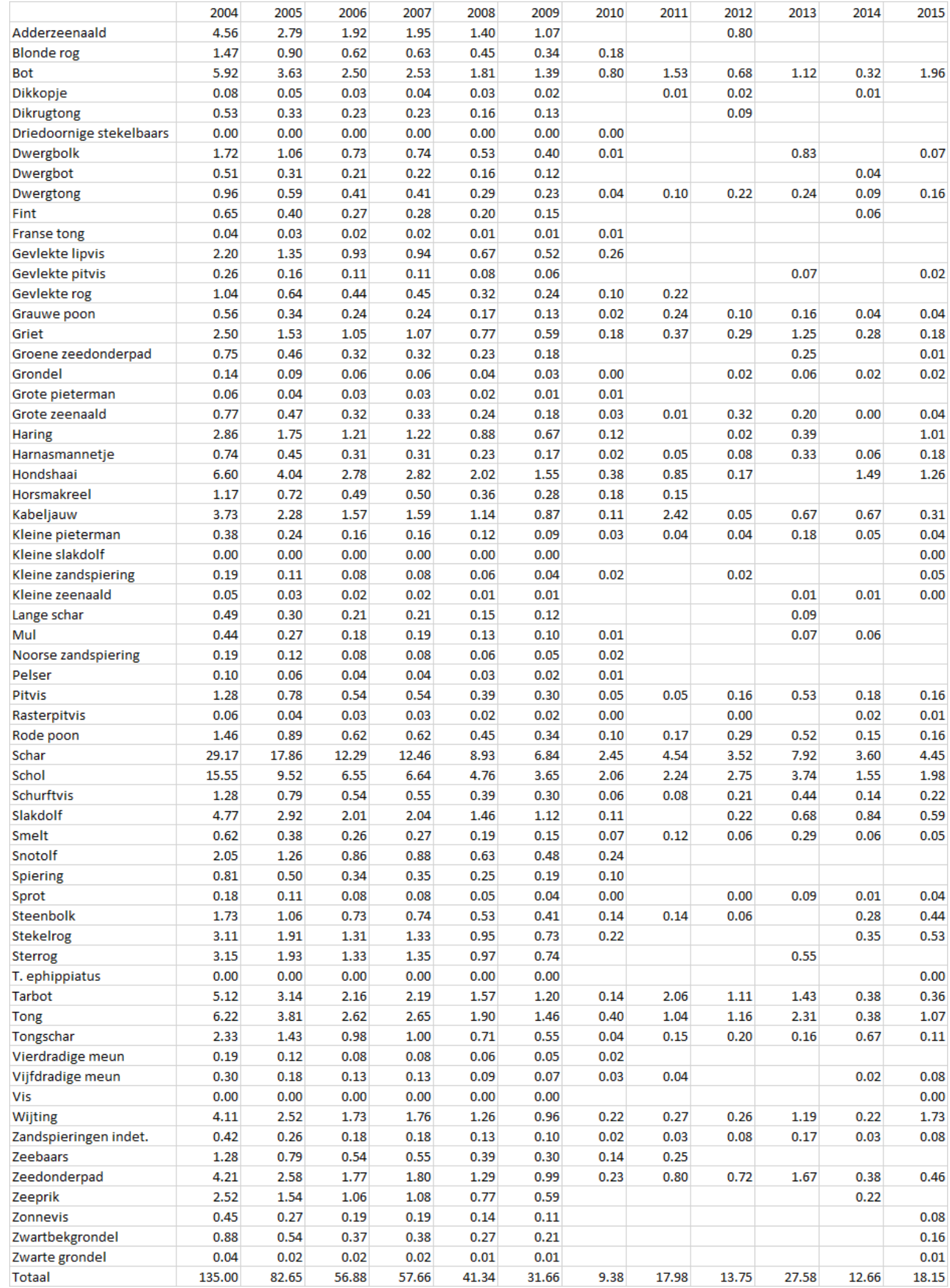


Tabel bij Tabel 0-13. Geschatte absolute benthosdiscards (ton) van platviskotters in de Voordelta, per soort en jaar

\begin{tabular}{|c|c|c|c|c|c|c|c|c|c|c|c|c|}
\hline & 2004 & 2005 & 2006 & 2007 & 2008 & 2009 & 2010 & 2011 & 2012 & 2013 & 2014 & 2015 \\
\hline Amerikaanse boormossel & 0.01 & 0.01 & 0.00 & 0.00 & 0.00 & 0.00 & & & & & & 0.00 \\
\hline Blauwpootzwemkrab & 1.33 & 0.81 & 0.56 & 0.57 & 0.41 & 0.31 & 0.01 & 0.01 & 0.32 & 0.61 & 0.14 & 0.13 \\
\hline Breedpootkrab & 0.00 & 0.00 & 0.00 & 0.00 & 0.00 & 0.00 & & & & & & 0.00 \\
\hline Fluwelen zwemkrab & 0.33 & 0.20 & 0.14 & 0.14 & 0.10 & 0.08 & 0.01 & 0.06 & 0.05 & 0.02 & 0.07 & 0.07 \\
\hline Gevlochten fuikhoorn & 0.62 & 0.38 & 0.26 & 0.26 & 0.19 & 0.14 & 0.00 & 0.00 & 0.09 & 0.22 & 0.01 & 0.27 \\
\hline Gewimperde zwemkrab & 0.10 & 0.06 & 0.04 & 0.04 & 0.03 & 0.02 & & & 0.00 & 0.01 & 0.00 & 0.06 \\
\hline Gewone heremietkreeft & 1.02 & 0.62 & 0.43 & 0.43 & 0.31 & 0.24 & 0.01 & 0.02 & 0.21 & 0.32 & 0.13 & 0.16 \\
\hline Gewone zwemkrab & 17.11 & 10.48 & 7.21 & 7.31 & 5.24 & 4.01 & 0.32 & 0.42 & 1.27 & 3.52 & 4.08 & 1.88 \\
\hline Glanzende tepelhoorn & 0.02 & 0.01 & 0.01 & 0.01 & 0.00 & 0.00 & 0.00 & 0.00 & 0.00 & 0.01 & 0.00 & 0.00 \\
\hline Grof geribde fuikhoorn & 0.15 & 0.09 & 0.06 & 0.06 & 0.05 & 0.03 & 0.00 & 0.00 & 0.00 & 0.00 & 0.00 & 0.03 \\
\hline Halfgeknotte strandschelp & 0.15 & 0.09 & 0.06 & 0.07 & 0.05 & 0.04 & 0.00 & 0.00 & 0.00 & 0.00 & 0.00 & 0.07 \\
\hline Hartegel & 0.27 & 0.16 & 0.11 & 0.11 & 0.08 & 0.06 & 0.00 & 0.01 & 0.03 & 0.04 & 0.05 & 0.04 \\
\hline Kleine heremietkreeft & 0.07 & 0.04 & 0.03 & 0.03 & 0.02 & 0.02 & & & & & 0.00 & 0.02 \\
\hline Kleine slangster & 0.12 & 0.08 & 0.05 & 0.05 & 0.04 & 0.03 & 0.00 & 0.00 & 0.01 & 0.07 & 0.01 & 0.03 \\
\hline Mossel & 0.43 & 0.26 & 0.18 & 0.18 & 0.13 & 0.10 & 0.00 & 0.00 & 0.00 & 0.11 & 0.01 & 0.27 \\
\hline Muiltje & 0.06 & 0.04 & 0.03 & 0.03 & 0.02 & 0.01 & 0.00 & & & 0.01 & 0.00 & 0.04 \\
\hline Nonnetje & 1.15 & 0.70 & 0.48 & 0.49 & 0.35 & 0.27 & 0.00 & 0.00 & 0.00 & 0.20 & 0.00 & 0.00 \\
\hline Noordzeekrab & 0.12 & 0.08 & 0.05 & 0.05 & 0.04 & 0.03 & 0.01 & 0.03 & 0.01 & & 0.01 & 0.05 \\
\hline Otterschelp & 0.05 & 0.03 & 0.02 & 0.02 & 0.01 & 0.01 & 0.00 & & 0.02 & & 0.00 & 0.01 \\
\hline Ovale strandschelp & 0.02 & 0.02 & 0.01 & 0.01 & 0.01 & 0.01 & 0.00 & & & & 0.00 & 0.01 \\
\hline Platte slijkgaper & 0.00 & 0.00 & 0.00 & 0.00 & 0.00 & 0.00 & & & 0.00 & & & \\
\hline Slangster & 18.34 & 11.23 & 7.73 & 7.83 & 5.62 & 4.30 & 0.74 & 2.19 & 2.49 & 5.21 & 2.09 & 3.72 \\
\hline Stevige strandschelp & 0.18 & 0.11 & 0.08 & 0.08 & 0.06 & 0.04 & 0.00 & 0.00 & 0.09 & 0.00 & 0.01 & 0.01 \\
\hline Zeekat & 0.01 & 0.01 & 0.01 & 0.01 & 0.00 & 0.00 & 0.00 & & 0.00 & & 0.00 & 0.00 \\
\hline Zeester & 50.48 & 30.91 & 21.27 & 21.56 & 15.46 & 11.84 & 0.46 & 17.18 & 7.59 & 16.75 & 5.89 & 3.37 \\
\hline Totaal & 101.17 & 61.94 & 42.63 & 43.21 & 30.98 & 23.72 & 1.57 & 20.08 & 13.64 & 28.74 & 15.25 & 11.24 \\
\hline
\end{tabular}


Tabel bij Tabel 0-14. Geschatte absolute vis- en garnaaldiscards (ton) van garnalenkotters in de Voordelta, per soort en jaar

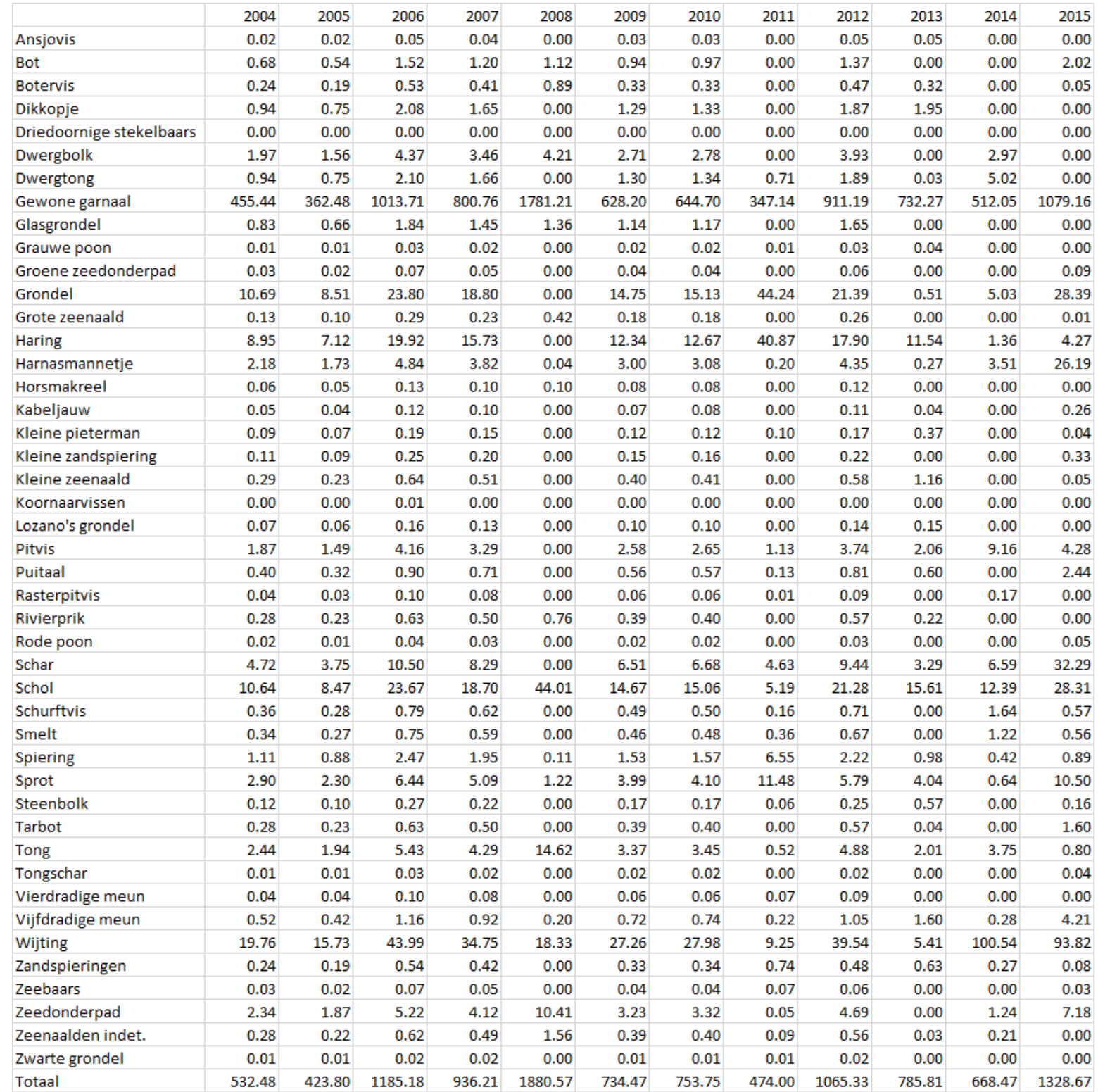




\section{Appendix 3. Impact onttrekking overige soorten}

Wijting

De wijting die gevangen wordt in de Voordelta is onderdeel van het bestand van de Noordzee en het oostelijk deel van het Kanaal. Voor dit bestand wordt door ICES jaarlijks bestandsschattingen gemaakt. Het wijtingbestand is niet in goede staat: De bestandsgrootte is lager dan gewenst en daalt sinds 1990 (ICES 2017). Aanwas van nieuwe vis is laag sinds 2003. De visserijsterfte is de gehele tijdserie hoger dan de streefwaarde FMSY. Dit is de waarde van visserijsterfte waarbij in theorie duurzame maximale vangsten gewaarborgd zijn.

Het belang van de Nederlandse boomkorkotters in de Voordelta ten opzichte van de gehele visserij in de Noordzee is zeer klein: $0.03-0.33 \%$ van alle onttrekkingen zijn voor rekening van de vangsten van de boomkorkotters in de Voordelta (tabel A3.1).

\section{Tongschar}

De tongschar die gevangen wordt door de platviskotters in de Voordelta is onderdeel van het bestand van de Noordzee, het oostelijk deel van het Kanaal, het Skagerrak en het Kattegat (ICES 2017). Voor dit bestand wordt door ICES geen bestandsschatting gemaakt en zijn geen tijdreeksen in de hoeveelheid discards beschikbaar. Wel wordt naar relatieve veranderingen in een index van de bestandsgrootte gekeken en zijn gegevens over de aanlandingen beschikbaar. Voor dit bestand kan dus niet direct gekeken worden naar bestandsomvang en het percentage onttrekking uit het bestand.

De garnalenvisserij vangt geen tongschar. Het belang van de Nederlandse platviskotters in de Voordelta ten opzichte van de aanlandingen van de gehele visserij in de Noordzee is zeer klein: 0$0.0014 \%$ van alle aanlandingen zijn voor rekening van de vangsten van de platviskotters in de Voordelta (tabel A3.2). Onttrekking vindt dan ook met name plaats via discards. Het deel van het wijtingbestand dat als discards wordt onttrokken in de Voordelta door de Nederlandse platviskotters is sterk afgenomen tussen 2004 en 2015.

Tarbot

De tarbot die gevangen wordt door de boomkorkotters in de Voordelta is onderdeel van het bestand van de Noordzee (ICES 2017). Voor dit bestand wordt door ICES geen absolute bestandsschatting gemaakt maar wordt alleen gekeken naar relatieve veranderingen in de bestandsgrootte. Er zijn geen tijdreeksen in de hoeveelheid discards beschikbaar. Wel zijn gegevens over de aanlandingen beschikbaar. Voor dit bestand kan dus niet zoals bij schol en tong direct gekeken worden naar bestandsomvang en het percentage onttrekking uit het bestand.

Het belang van de Nederlandse boomkorkotters in de Voordelta ten opzichte van de gehele visserij in de Noordzee is zeer klein: $0.02-0.15 \%$ van alle aanlandingen zijn voor rekening van de aanlandingen van de boomkorkotters in de Voordelta (tabel A3.3). Zowel de aanlandingen als de discards in de Voordelta nemen af gedurende de tijdreeks. 


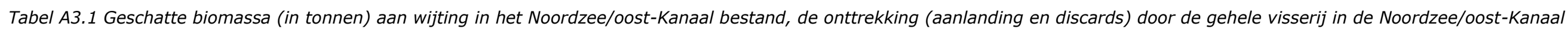

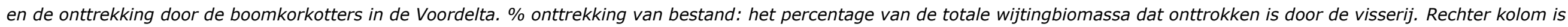
het \% onttrekking door de boomkorkotters in de Voordelta, van de hele visserij. '-' niet beschikbaar.

\begin{tabular}{|c|c|c|c|c|c|c|c|c|c|c|c|}
\hline \multirow[b]{2}{*}{ jaar } & \multicolumn{2}{|c|}{$\begin{array}{l}\text { wijtingbestand } \\
\text { NZ/oost-Kanaal }\end{array}$} & \multirow[b]{2}{*}{ aanlanding } & \multicolumn{2}{|c|}{$\begin{array}{c}\text { gehele visserij } \\
\mathrm{NZ} / \mathrm{SK}\end{array}$} & \multirow[b]{2}{*}{$\begin{array}{l}\text { Aanlanding } \\
\text { platviskotters }\end{array}$} & \multicolumn{2}{|c|}{ Boomkorkotters in de Voordelta } & \multirow[b]{2}{*}{$\begin{array}{c}\text { Discards } \\
\text { garnalenkotters }\end{array}$} & \multirow[b]{2}{*}{$\begin{array}{c}\% \text { onttrekking van } \\
\text { het bestand }\end{array}$} & \multirow{2}{*}{$\begin{array}{c}\% \text { onttrekking door } \\
\text { boomkorkotters in de } \\
\text { Voordelta, van totale } \\
\text { onttrekking }\end{array}$} \\
\hline & paaibestand & $\begin{array}{c}\text { totaal } \\
\text { bestand }\end{array}$ & & discards & $\begin{array}{c}\% \text { onttrekking } \\
\text { van bestand }\end{array}$ & & $\begin{array}{c}\text { Aanlanding } \\
\text { garnalenkotters }\end{array}$ & $\begin{array}{c}\text { Discards } \\
\text { platviskotters }\end{array}$ & & & \\
\hline 2000 & 344713 & 856619 & 37743 & 26063 & 7.4 & & & & & & \\
\hline 2001 & 421586 & 801579 & 26005 & 19237 & 5.6 & & & & & & \\
\hline 2002 & 383340 & 606256 & 27950 & 18501 & 7.7 & & & & & & \\
\hline 2004 & 239720 & 364002 & 14509 & 19048 & 9.2 & 2.6 & - & 4.1 & 19.8 & - & - \\
\hline 2005 & 199482 & 380442 & 16359 & 12525 & 7.6 & 2.1 & - & 2.5 & 15.7 & - & - \\
\hline 2006 & 180601 & 373156 & 20728 & 16310 & 9.9 & 0.2 & 5.2 & 1.7 & 44.0 & 0.0137 & 0.138 \\
\hline 2007 & 171915 & 310686 & 20154 & 6971 & 8.7 & 0.2 & 0.4 & 1.8 & 34.7 & 0.0119 & 0.136 \\
\hline 2008 & 193429 & 456552 & 17951 & 10296 & 6.2 & 2.2 & 18.7 & 1.3 & 18.3 & 0.0089 & 0.143 \\
\hline 2009 & 262550 & 461318 & 19434 & 7705 & 5.9 & 3.4 & 13.8 & 1.0 & 27.3 & 0.0098 & 0.167 \\
\hline 2010 & 291072 & 484244 & 19570 & 11577 & 6.4 & 1.0 & 6.0 & 0.2 & 28.0 & 0.0073 & 0.113 \\
\hline 2012 & 309860 & 446216 & 17110 & 7968 & 5.6 & 0.3 & 0.6 & 0.3 & 39.5 & 0.0091 & 0.162 \\
\hline 2013 & 265474 & 363584 & 20865 & 5976 & 7.4 & 0.4 & 0.0 & 1.2 & 5.4 & 0.0019 & 0.026 \\
\hline 2014 & 237652 & 455526 & 20225 & 10451 & 6.7 & 0.1 & 0.1 & 0.2 & 100.5 & 0.0221 & 0.329 \\
\hline 2015 & 246870 & 484595 & 19760 & 13428 & 6.8 & 1.1 & 7.5 & 1.7 & 93.8 & 0.0215 & 0.314 \\
\hline
\end{tabular}




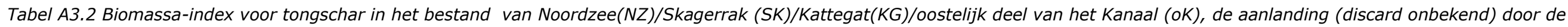

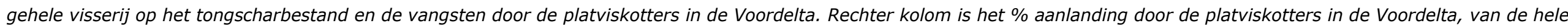
visserij. '-' niet beschikbaar. NB: de garnalenkotters vangen geen wijting.

\begin{tabular}{|c|c|c|c|c|c|}
\hline \multirow[b]{2}{*}{ jaar } & \multirow{2}{*}{$\begin{array}{l}\text { tongscharbestand } \\
\mathrm{NZ} / \mathrm{SK} / \mathrm{KG} / \mathrm{oK} \\
\text { biomassa-index }\end{array}$} & \multirow{2}{*}{$\begin{array}{l}\text { gehele visserij } \\
\text { NZ/SK/KG/oK } \\
\text { aanlanding }\end{array}$} & \multicolumn{2}{|c|}{ platviskotters in Voordelta } & \multirow{2}{*}{$\begin{array}{l}\text { \% aanlanding door } \\
\text { platviskotters in de } \\
\text { Voordelta, van } \\
\text { totale aanlanding }\end{array}$} \\
\hline & & & aanlanding & discards & \\
\hline 2000 & 1.702 & 7170 & - & - & - \\
\hline 2001 & 1.377 & 6455 & - & - & - \\
\hline 2002 & 1.819 & 4819 & - & - & - \\
\hline 2003 & 1.707 & 4716 & - & - & - \\
\hline 2004 & 1.683 & 4569 & 0.00 & 2.33 & 0.0000 \\
\hline 2005 & 1.22 & 4463 & 0.00 & 1.43 & 0.0000 \\
\hline 2006 & 1.02 & 4290 & 0.00 & 0.98 & 0.0000 \\
\hline 2007 & 1.331 & 4488 & 0.00 & 1.00 & 0.0000 \\
\hline 2008 & 1.331 & 3975 & 0.04 & 0.71 & 0.0009 \\
\hline 2009 & 0.862 & 3394 & 0.05 & 0.55 & 0.0014 \\
\hline 2010 & 0.954 & 3201 & 0.00 & 0.04 & 0.0000 \\
\hline 2011 & 1.265 & 4022 & 0.02 & 0.15 & 0.0005 \\
\hline 2012 & 1.895 & 4026 & 0.02 & 0.20 & 0.0004 \\
\hline 2013 & 1.249 & 3761 & 0.01 & 0.16 & 0.0003 \\
\hline 2014 & 0.968 & 3689 & 0.02 & 0.67 & 0.0005 \\
\hline 2015 & 1.019 & - & 0.06 & 0.11 & - \\
\hline
\end{tabular}




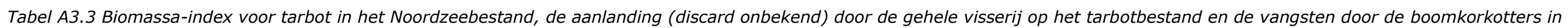

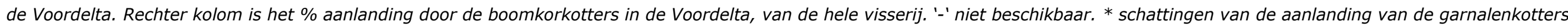
zijn niet beschikbaar voor 2004 en 2005 maar gezien de lage schattingen in de jaren erna, worden deze aangenomen verwaarloosbaar te zijn.

\begin{tabular}{|c|c|c|c|c|c|c|c|}
\hline \multirow[b]{2}{*}{ jaar } & \multirow{2}{*}{$\begin{array}{l}\text { tarbotbestand NZ } \\
\text { biomassa-index }\end{array}$} & \multirow{2}{*}{$\begin{array}{c}\text { gehele visserij NZ } \\
\text { aanlanding }\end{array}$} & \multicolumn{4}{|c|}{ boomkorkotters in de Voordelta } & \multirow{2}{*}{$\begin{array}{l}\text { \% aanlanding door } \\
\text { boomkorkotters in } \\
\text { de Voordelta, van } \\
\text { totale aanlanding* }\end{array}$} \\
\hline & & & $\begin{array}{c}\text { aanlanding } \\
\text { platviskotters }\end{array}$ & $\begin{array}{c}\text { aanlanding } \\
\text { garnalenkotters }\end{array}$ & $\begin{array}{c}\text { discards } \\
\text { platviskotters }\end{array}$ & $\begin{array}{c}\text { discards } \\
\text { garnalenkotters }\end{array}$ & \\
\hline 2000 & 0.9 & 4026 & & & & & - \\
\hline 2001 & 0.6 & 4101 & & & & & - \\
\hline 2002 & 0.4 & 3750 & & & & & - \\
\hline 2003 & 0.3 & 3375 & & & & & - \\
\hline 2004 & 0.3 & 3319 & 4.2 & - & 5.1 & 0.3 & 0.13 \\
\hline 2005 & 0.2 & 3195 & 4.7 & - & 3.1 & 0.2 & 0.15 \\
\hline 2006 & 0.3 & 2977 & 2.7 & 0.0 & 2.2 & 0.6 & 0.09 \\
\hline 2007 & 0.4 & 3510 & 3.0 & 0.0 & 2.2 & 0.5 & 0.08 \\
\hline 2008 & 0.5 & 3007 & 2.5 & 0.0 & 1.6 & 0.0 & 0.08 \\
\hline 2009 & 0.5 & 3091 & 1.5 & 0.1 & 1.2 & 0.4 & 0.05 \\
\hline 2010 & 0.5 & 2692 & 0.5 & 0.0 & 0.1 & 0.4 & 0.02 \\
\hline 2011 & 0.4 & 2807 & 1.1 & 0.0 & 2.1 & 0.0 & 0.04 \\
\hline 2012 & 0.4 & 2914 & 1.1 & 0.1 & 1.1 & 0.6 & 0.04 \\
\hline 2013 & 0.5 & 3084 & 1.1 & 0.0 & 1.4 & 0.0 & 0.04 \\
\hline 2014 & 0.4 & 2834 & 0.6 & 0.0 & 0.4 & 0.0 & 0.02 \\
\hline 2015 & 0.9 & - & 1.0 & 0.0 & 0.4 & 1.6 & - \\
\hline
\end{tabular}




\section{Appendix 4 Berekening visgrond en inspanning per hectare visgrond}

Vraag : Hoeveel oppervlakte aan visgronden is verdwenen voor de platviskotters, door de aanleg van de Maasvlakte2 en het instellen van het BBG?

Er wordt, tenzij anders vermeld gerekend met shapefiles opgesteld voor de 2013-situatie.

\section{Wateroppervlaktes:}

Voordelta $=$ Het oppervlak tussen 2008-2013 = 92.271 ha. De shapefile is gemaakt in 2013, dus van na de aanleg van MV2 is, maar voorafgaand aan de verandering in Voordelta-vorm in 2014. (In 2014 is de grens aan zeezijde gelijk getrokken met de doorgaande $20 \mathrm{~m}$ dieptelijn. Hierdoor is het gebied enigszins verkleind. Aangezien wij voornamelijk kijken naar eerdere jaren, is deze verandering hier genegeerd).

Maasvlakte $=$ in de Voordelta aangelegd. Het oppervlak is 2.455 ha. Hiervan is grofweg 2.000 door de ruimte-inname door de MV2 en de rest door teloorgang van H1110-gebied door erosie ed. Het gebied waar niet meer gevist kan worden is 2.000 hectare. De aanleg is begonnen in september 2008 .

Samengevat:

- $\quad$ voor de aanleg was het oppervlak $92.271+2.000(M V)=94.271$

- $\quad$ sinds de aanleg was het oppervlak 92.271

\section{Voor visserij gesloten gebieden:}

Voor 2008 gebied gesloten voor alle visserij:

- $\quad$ 'accentnatuurgebieden' $=4.753$ ha (volgens Beheerplan RWS ${ }^{18}$ )

- $\quad$ De vaargeul Slijkgat $=867$ ha.

Sinds 2008 gesloten voor platvisvisserij:

- $\quad$ BBG $=24.550$ ha

(Het uiteindelijk oppervlak van het BBG is groter, omdat de gebieden die al gesloten waren voor visserij niet aangewend kunnen worden als BBG (de accentnatuurgebieden en vaargeur Slijkgat). Ook H1140 gebied telt niet mee.)

Sinds 2008 gesloten voor garnaalvisserij:

- $\quad$ Bollen van Ooster $=3.902$ ha

- $\quad$ Bollen van het nieuwe zand $=4.144$ ha

\section{Samengevat}

- Voor de aanleg van het BBG was het gesloten gebied 4.753 ha

- $\quad$ Na de aanleg is het gesloten gebied voor

$$
\begin{aligned}
& \text { Platvis }=4.753+24.550=29.303 \text { ha } \\
& \text { Garnaal }=4.753+8.046=12.799 \text { ha }
\end{aligned}
$$

\section{Bevisbaar gebied:}

Voor 2008 was er 94.271-4.753 = 89.518 ha bevisbaar gebied voor de platviskotters, Na 2008 is er voor

- $\quad$ platvis $=92.271-29.303=62.968 \mathrm{ha} . \mathrm{Er}$ is dus $70 \%$ over dus.

- Garnaal $=92.271-12.799=79.472$ ha. $(89 \%$ over $)$

\footnotetext{
${ }^{18}$ http://www.rwsnatura2000.nl/Gebieden/VD_Voordelta/VD_Documenten/default.aspx\#folder=486339
} 


\section{Visuren / bevisbaar gebied:}

Vanuit hoofdstuk 3 is informatie over de hoeveelheid visserij-inspanning in de Voordelta beschikbaar. Hiermee kan de hoeveelheid visuren per hectare bevisbaar gebied berekend worden voor de jaren rondom de instelling van het BBG:

\begin{tabular}{cccc|ccc} 
& \multicolumn{3}{c|}{ Visuren } & \multicolumn{3}{c}{ Visuren/hectare bevisbaar gebied } \\
& platviskotters & garnalenkotters & totaal & platviskotters & garnalenkotters & totaal \\
\hline 2006 & 3883 & 22194 & 26077 & 0.04 & 0.25 & 0.29 \\
2007 & 3936 & 17513 & 21450 & 0.04 & 0.20 & 0.24 \\
& & & & & & \\
2009 & 2161 & 13825 & 15987 & 0.03 & 0.17 & 0.21 \\
2010 & 1099 & 14158 & 15256 & 0.02 & 0.18 & 0.20
\end{tabular}




\section{Verantwoording}

Rapport: $\quad$ C105/17

Projectnummer: 4316100086

Dit rapport is met grote zorgvuldigheid tot stand gekomen. De wetenschappelijke kwaliteit is intern getoetst door een collega-onderzoeker en het verantwoordelijk lid van het managementteam van Wageningen Marine Research.

Akkoord:

Dr. J. Batsleer

Onderzoeker

Handtekening:

Datum:

20 december 2017

Akkoord:

Drs. J. Asjes

Manager Integratie

Handtekening:

Datum:

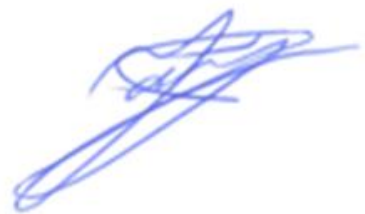

20 december 2017 
Wageningen Marine Research

T +31 (0)317480900

E marine-research@wur.nl

www.wur.nl/marine-research

Visitors address

-Ankerpark 271781 AG Den Helder

- Korringaweg 7, 4401 NT Yerseke

-Haringkade 1, 1976 CP IJmuiden
Wageningen Marine Research is the Netherlands research institute established to provide the scientific support that is essential for developing policies and innovation in respect of the marine environment, fishery activities, aquaculture and the maritime sector.

Wageningen University \& Research is specialised in the domain of healthy food and living environment.

\section{The Wageningen Marine Research vision:}

'To explore the potential of marine nature to improve the quality of life'

\section{The Wageningen Marine Research mission:}

- To conduct research with the aim of acquiring knowledge and offering advice on the sustainable management and use of marine and coastal areas.

-Wageningen Marine Research is an independent, leading scientific research institute

Wageningen Marine Research Wageningen UR is part of the international knowledge organisation Wageningen UR (University \& Research centre). Within Wageningen UR, nine specialised research institutes of Stichting Wageningen Research (a Foundation) have joined forces with Wageningen University to help answer the most important questions in the domain of healthy food and living environment. 